Historic, Archive Document

Do not assume content reflects current scientific knowledge, policies, or practices. 



\section{SUGGESTIONS To Our CUSTOMERS}

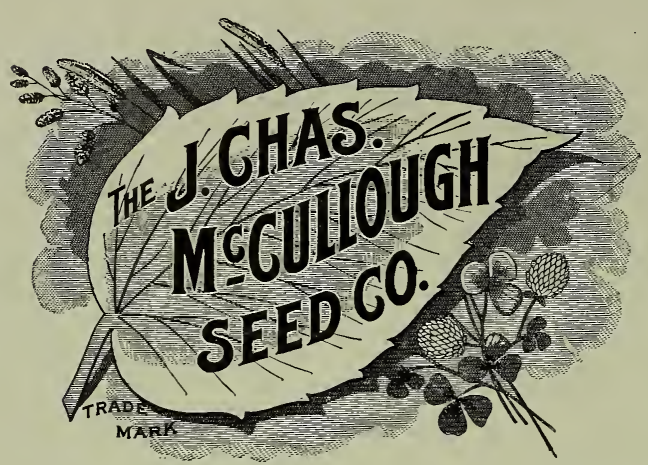

With each order write your NAME, POST-OFFICE, COUNTY and STATE in full. When Freight Office is different from Post Office, give both.

Send money with order, by P. O. Order, Registered Letter, Express Money Order, or Draft on Cincinnati or New York.

Personal Checks.-DO NOT SEND personal checks, as we are obliged to pay for collecting same and will therefore have to deduct this charge from your order. Besides, orders are held until our banks report checks paid, thus causing needless delay.

OUR PRICES INCLUDE POSTAGE on all Vegetable and Flower Seeds by the packet, ounce and pound except Peas, Beans and Corn, when 10c per pound must be added to the catalogue prices for postage.

Order Early-It will greatly facilitate shipments if orders are sent early. We aim to send all orders the day received, but during the busy season it is sometimes impossible-hence the advisability of ordering early.

Customers who buy at our counters, or wish to pay their own Express charges, may deduct ten cents per pound on all seeds bought by, the pound, if quoted at prepaid rates.

All prices in this catalogue subject to change without notice.

Prepay Stations.--If there is no agent at your station, remit extra for the freight. If you neglect to do this, we will ship to the nearest station wh _.e there is an agent.

Should you change your address, we will esteem it a favor if you will notify us, so we can forward our Catalogue with regularity; if you receive two Catalogues of the same kind, please hand one to some friend who has a garden.

Should an error occur, we desire to be promptly informed, and will take pleasure in making satisfactory corrections.

About Warranting Seeds.-We have often been asked if we "guarantee or warrant our Seeds." We beg to state plainly, we do not, for the reason that practical experience has assured us of the fact that crops may fail, no matter how fresh or pure the seed sown may be. We trust that our customers will fully realize that it is to our interest to send none but the best quality of seeds.

To secure success, however, it is necessary that the customer should do his part well, or our good seeds will be ruined. With the best of management and good seeds there will be an occasional unaccountable failure. The best of gardeners sometimes fail, and try again with the same seed with good results.

We, The J. Chas. McCullough Seed Co., give no warranty, express or implied, as to description, quality, productiveness or any other matter of any seeds, bulbs, or plants we send out, and we will not be in any way responsible for the crop. If the purchaser does not accept the goods on these terms, they are at once to be returned and the amount paid will be refunded. If they are kept it will be taken as proof that they are satisfactory.

We cordially invite all our friends to call and inspect a MODERN SEED ESTABLISHMENT.

\section{THE J. CHAS. MCULLOUGH SEED CO.}

\section{J. CHAS. MC CULLOUGH, President}

SALESROOM AND GARDEN SEED DEPARTMENT. 230 AND 232 EAST FOURTH ST.
CINCINNATI, 0 .

OFFICE AN D SEED CLEANING PLANT. 601-603-605 EAST FIFTH ST. FIFTH, LOCK AND EGGLESTON AVE.

PRIVATE EXChANGE, LONG DISTANCE PHONE,

CANAL 2603

Connecting All Departments. 


\section{Views of Our Seed Ranch, near Solvang, California}

These views are reproduced from photographs, taken on our Seed Ranch, located in one of the most fertile valleys of California, near Solvang, where climate and soil are particularly adapted to growing the best strains of Beans, Vegetable and Flower Seeds.

Mr. H. T. McCullough has the management of this ranch, and all crops will be grown under his personal supervision.

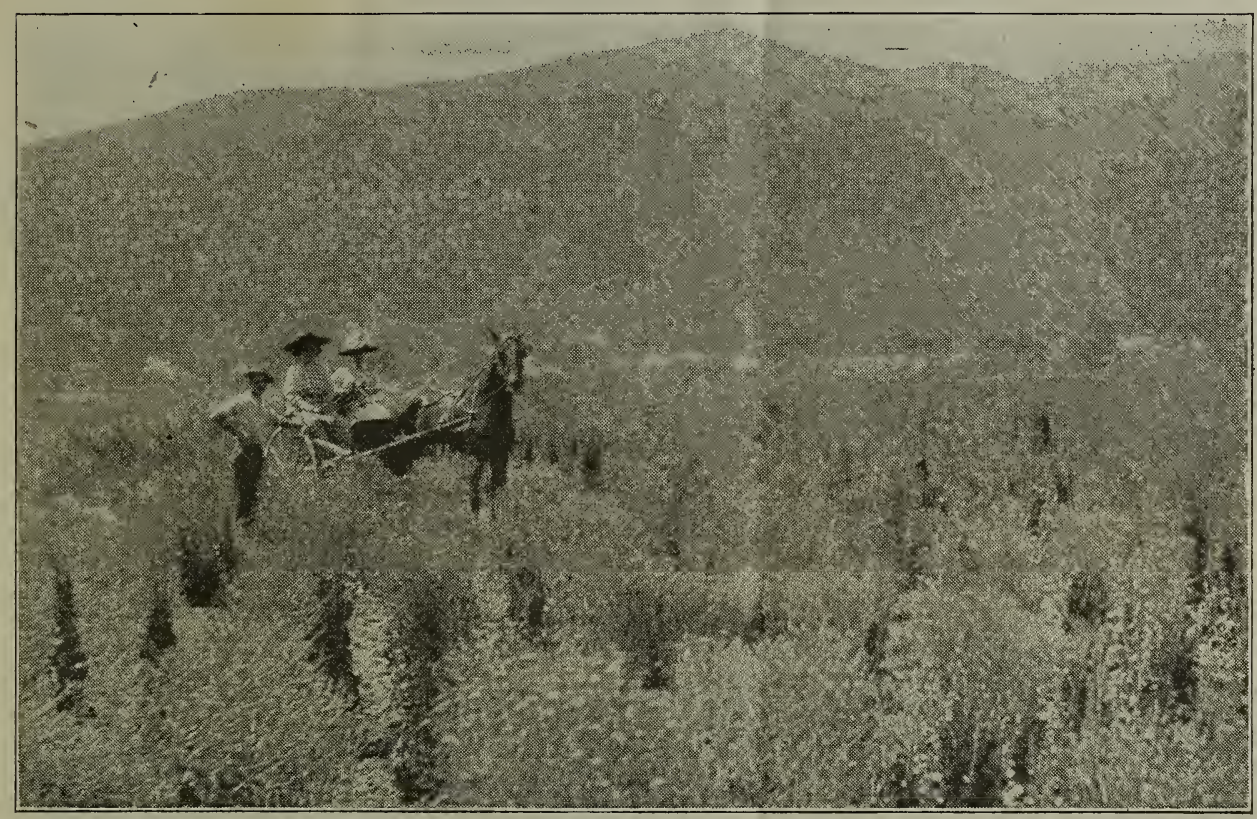

Field of Black Seeded Simpson Lettuce Seed, Ready to Harvest.

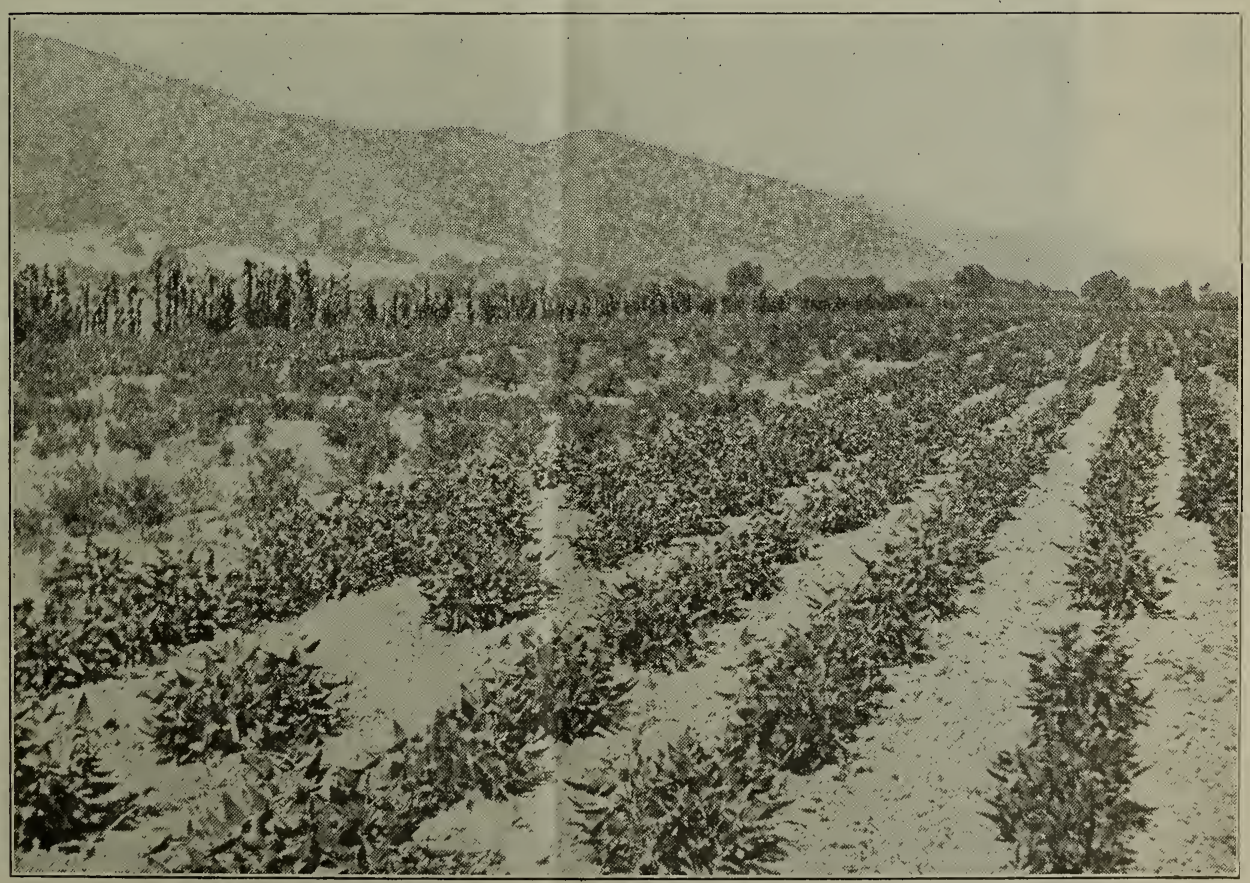

Field Showing Corn Beans, Burpee's Bush Lima Beans, and Danver's Half Long Carrots. 


\section{Views of Our Seed Ranch, near Solvang, California}

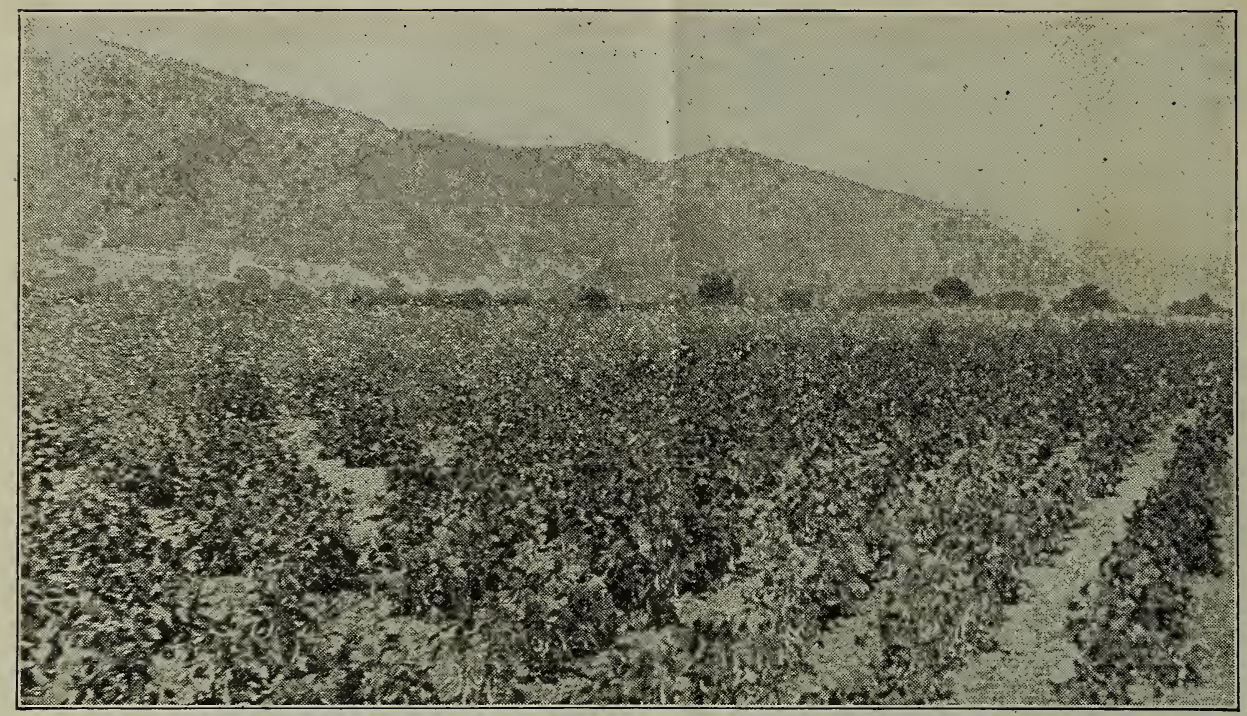

Part’of Trial Grounds, Showing Growing Crops of Prize Head Lettuce, Stringless Green Pod Beans, and Cincinnati Market Radish.

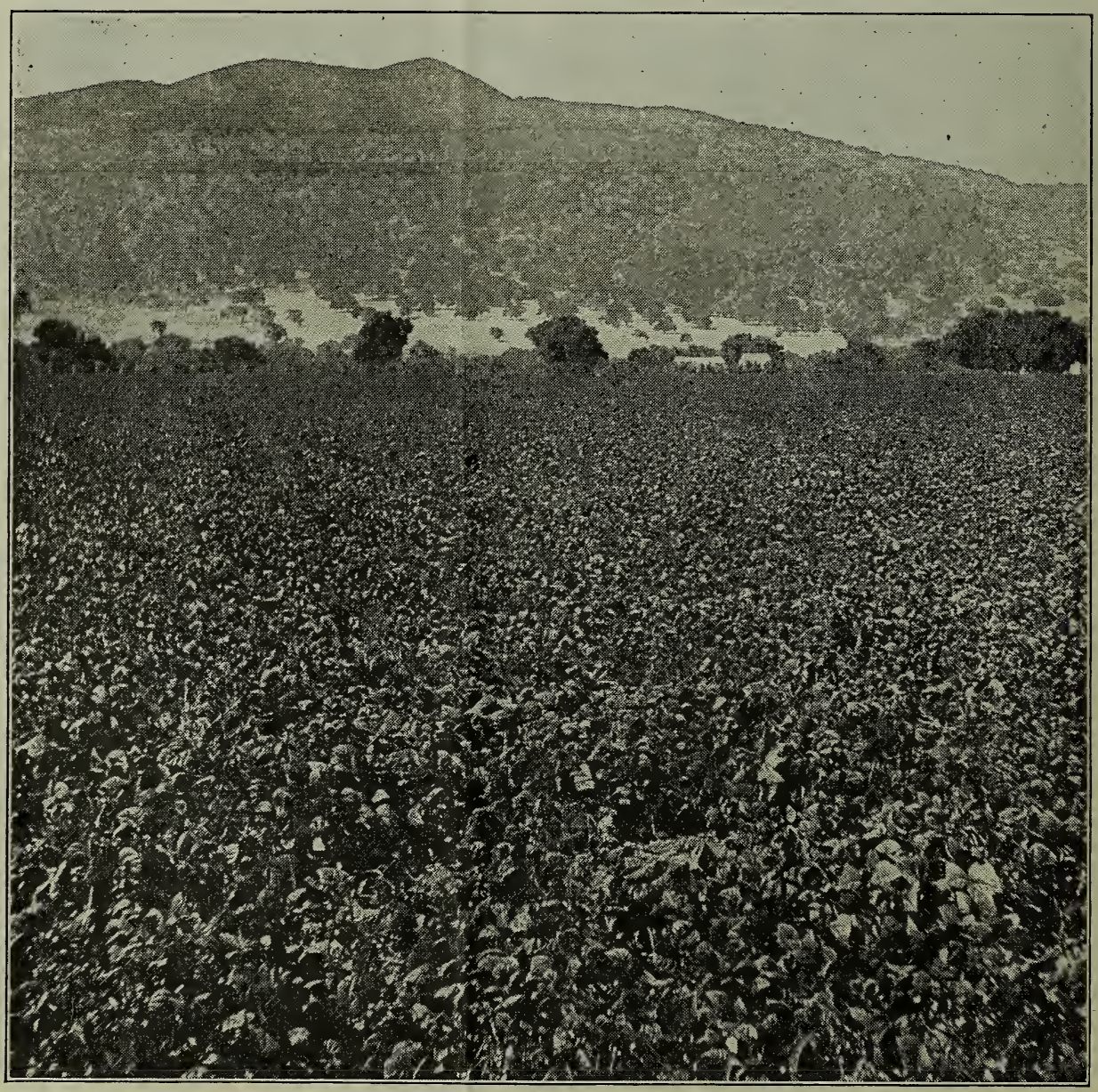




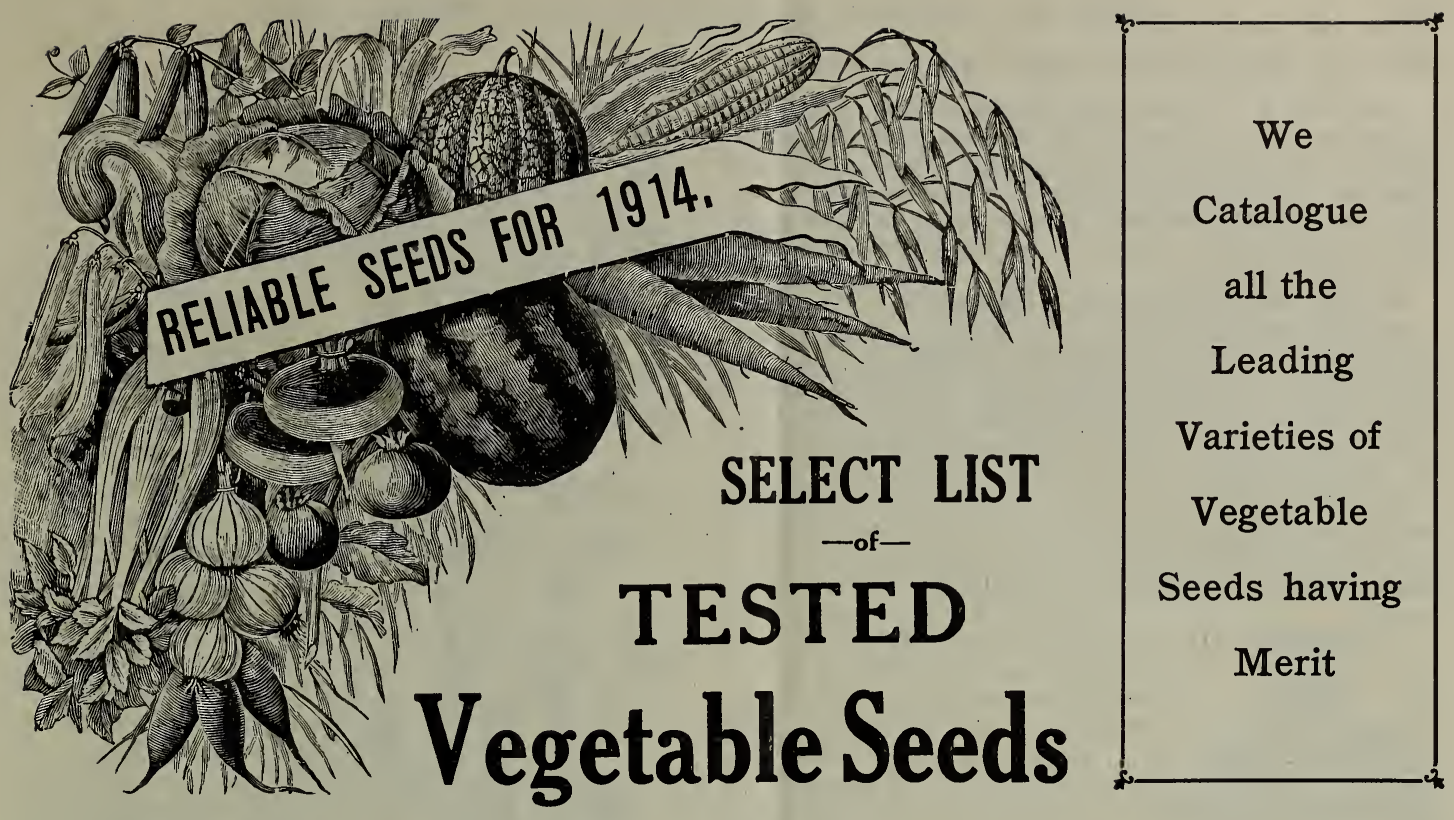

SEEDS POSTPAID BY MAIL.

We will send by Mail, Postage Paid, any of the following list of Vegetable and Flower Seeds; except Peas, Beans, Corn and Field Seeds; for these add 10 cents per pound to pay postage.

\section{SPECIAL OFFER ON SEEDS IN PACKETS ONLY}

7 Five-Cent packets for 25 Cts.

15 Five-Cent packets for $50 \mathrm{Cts}$.

40 Five-Cent packets for $\$ 1.00$. All packets, unless otherwise mentioned, 5 Cents each.

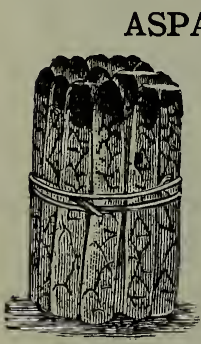
ASPARAGUS (Spargal, Ger.)

Palmetto-An improved early variety, vigorous growth and large stocks, 10 cts oz.; 20 cts. $\frac{1}{4}$ lb.; 60 cts. lb.

Barr's Mammoth-A fine, large-stemmed green variety. $10 \mathrm{cts}$. Oz.; 25 cts. $\frac{1}{4} \mathrm{lb}$.

Columbian Mammoth White-Large, white stalks. 10 ets. Oz.; 25 cts. $\frac{1}{4} \mathrm{lb}$.

\section{ASPARAGUS ROOTS.}

May be either planted in fall or spring. Dig up your ground deep, put plenty of well-rooted manure thoroughly mixed in the soil, throw out a bed about four or five inches deep, lay the plants in by spreading the roots out well and scatter the dirt over the plants about four inches, or the depth of the ground thrown out, firm the dirt well around the plants by patting it down well with spade or shovel, then top dress the ground with about three inches of wellrooted manure, and scatter salt enough over the top of this to make the ground white enough to track a rabbit. The second year after planting you will be able to harvest enough asparagus for a good-sized family from a bed of about 200 plants. You can plant about 200 plants in a bed three feet wide and fifteen feet long. You should keep the crown of the asparagus cut regularly so it will produce from three and one-half to seven pounds of asparagus, and when planted in small beds, where it can be well mulched and cared for, will even do much better than this. It is necessary to start with good roots. It depends much more on the care taken of the plants and the plant food given them than it does the variety planted. Salt should be put on at the end of every season, in the spring of the year.

\section{ASPARAGUS ROOTS-Two-year-old roots.}

\begin{tabular}{ccc} 
Per & Per & \multicolumn{1}{c}{ Per } \\
100 & 500 & 1,000 \\
.$\$ 1.00$ & $\$ 4.25$ & $\$ 7.00$ \\
1.00 & 4.25 & 7.00 \\
.80 & 3.75 & 6.00 \\
1.00 & 4.25 & 7.00
\end{tabular}

Barr's Mammoth............\$1.00 \$4.25 $\$ 7.00$

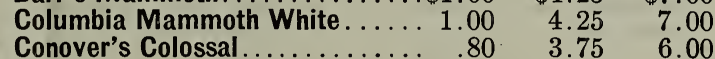

Palmetto................... $1.00 \quad 4.25 \quad 7.00$

BORECOLE or KALE (Blaetter Kohl, Ger.)

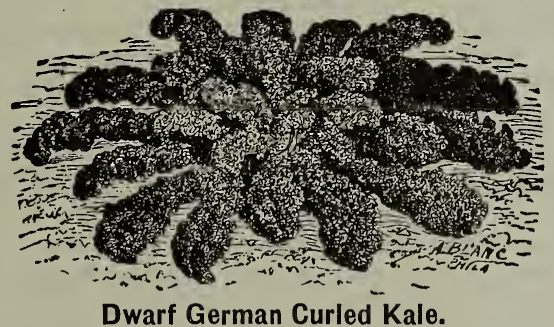

This may be sown in May and transplanted in the same way as cabbage. They make very tender and delicious greens in the Fall. Very hardy, easily grown, they deserve more general cultivation. One ounce to one hundred yards of row.

Dwarf German Kale-Very hardy, a standard variety, 10 cts. oz.; 20 cts. $\frac{1}{4}$ lb.; 60 cts. lb.

Siberian-Sometimes called "Sprouts" and "German Greens." The plant is low but spreading and very hardy. 10 cts. oz.; 20 cts. $\frac{1}{4} \mathrm{lb}$; 50 cts. lb.

Dwarf Green Curled Scotch-Grows about 12 inches in height and spreads, under good cultivation, to three feet in diameter. The leaves are bright green, beautifully curled and very tender. Allow to get a slight touch of frost before using. $10 \mathrm{cts}$. oz.; 25 cts. $\frac{1}{4} \mathrm{lb}$; 65 cts. lb. 


\section{BEANS (Bohne, Ger.) Dwarf or Bush Varieties}

The Bean is a tender plant, and, therefore, should not be planted until danger from frost is past and then may be planted with success throughout the entire summer in rotation. Sow in open ground, from the end of April to the first of August, in rows two feet apart and thin from six to eight inches in the row. 1 quart to 100 feet of drill, 2 bushels to the acre.

Add 10 cents per pint, 15 cents per quart, if sent by mail.

Burpee's Stringless Green Pod-It surpasses all others in crispiness, tenderness and flavor, and is the mostoprolific bean grown. The pods are $4 \frac{1}{4}$ to $5 \frac{1}{2}$ inches long, nearly round, slightly curved and of the best quality. They remain long in edible condition and are never stringy. 15 cts. pt.; 25 cts. qt.

Giant Stringless Green Pod-It is positively stringless, and ripens earlier than the Valentine. The pods which are produced in abundance on the vines, are long and fleshy; perfectly round, meaty and finest quality. $15 \mathrm{cts}$ pt.; 25 cts. qt.

Fordhook Bush Lima-Is fully thirty-three and one-third per cent. a heavier cropper and, therefore, is bound to entirely displace the Kumerle (Dreer's or Thorburn's) Bush Lima. In season it is from four to six days earlier. The green beans, even when of full size, are tender, juicy and sweet in flavor when cooked. 20 cts. pt.; 35 cts. qt.

Henderson's Bush Lima-Grows in compact bush form, 15 to 18 inches high. It is at least two weeks earlier than any of the climbing Limas. 15 cts. pt.; 25 cts. qt.

Burpee's Bush Lima-This is a bush form of the well known large white Lima bean; is very fixed in its bush character, growing to a uniform height of about 20 inches. 15 cts. pt.; 30 cts. qt.

Tennessee Green Pod-This dwarf Snap Bean, although new to the seed trade, has for several years been grown in the South, and wherever known is freely spoken of in terms of highest praise. Vine prolific, foliage dark green, pods very long, flat, bright green and of most excellent quality.

\section{5 cts. pt.; 25 cts. qt.}

Black Valentine-This variety is very productive. Pods are extremely long, round and straight, and are quite attractive in appearance. The quality is also good, pods being decidedly tender. Suitable for both early and late planting, being extremely hardy. 15 cts. pt.; 25 cts. qt.

Round-Pod Six Weeks-It is extra early, a vigorous grower and very productive. Compared with the Long Yellow Six. Weeks Bean, it is more prolific, the pods are longer. 15 cts. pt.; 25 cts. qt.

Early Long Yellow Six Weeks-A fine string bean, very prolific. 10 cts. pt.; 20 cts. qt.

Horticultural Dwarf-Excellent quality as a shell bean, either green or dry. 15 cts. pt.; 25 cts. qt.

Improved Round Pod Red Valentine-Ten days earlier than ordinary Valentine. 15 cts. pt.; 25 cts. qt.

Early Red Valentine-Round, green pods, early and tender, good for string or pickling. 10 cts. pt.; 20 cts. qt.

Bountiful-Early, tender and fine flavor. 15 cts. pt.; 25 cts. qt.

Golden Wax-Round, golden, waxy pods, early, prolific, stringless. The finest wax bean. 15 cts. pt.; 25 cts qt.

Black Wax-Round, wax pods, early, stringless, solid and tender, 15 cts. pt.; 25 cts. qt.

White Wax-An excellent snap bean, also fine for shelling 15 cts. pt.; 25 cts. qt.

Refugee-Hardy, productive, flesh thick and tender, one of the best for pickling. 10 cts. pt.; 20 cts. qt.

White Marrow-A standard field variety, excellent for shelling. $10 \mathrm{cts}$. pt.; 20 cts. qt.

Navy-An old standard variety, good for winter use. 10 cts. pt.; 20 cts. qt.; $\$ 1.00$ peck.

White Kidney-An excellent shell bean, the best for Winter use. 10 cts. pt.; 20 cts. qt.; $\$ 1.25$ peck.

Red Kidney-Similar to the above, except in color. 10 cts. pt.; 20 cts. qt.; $\$ 1.25$ peck.

Wardwell's Kidney Wax-Vines vigorous, hardy and productive. The pods are large; smooth and showy, tender and stringless, excellent winter shelled sort. 15 cts. pt.; 25 cts. qt.

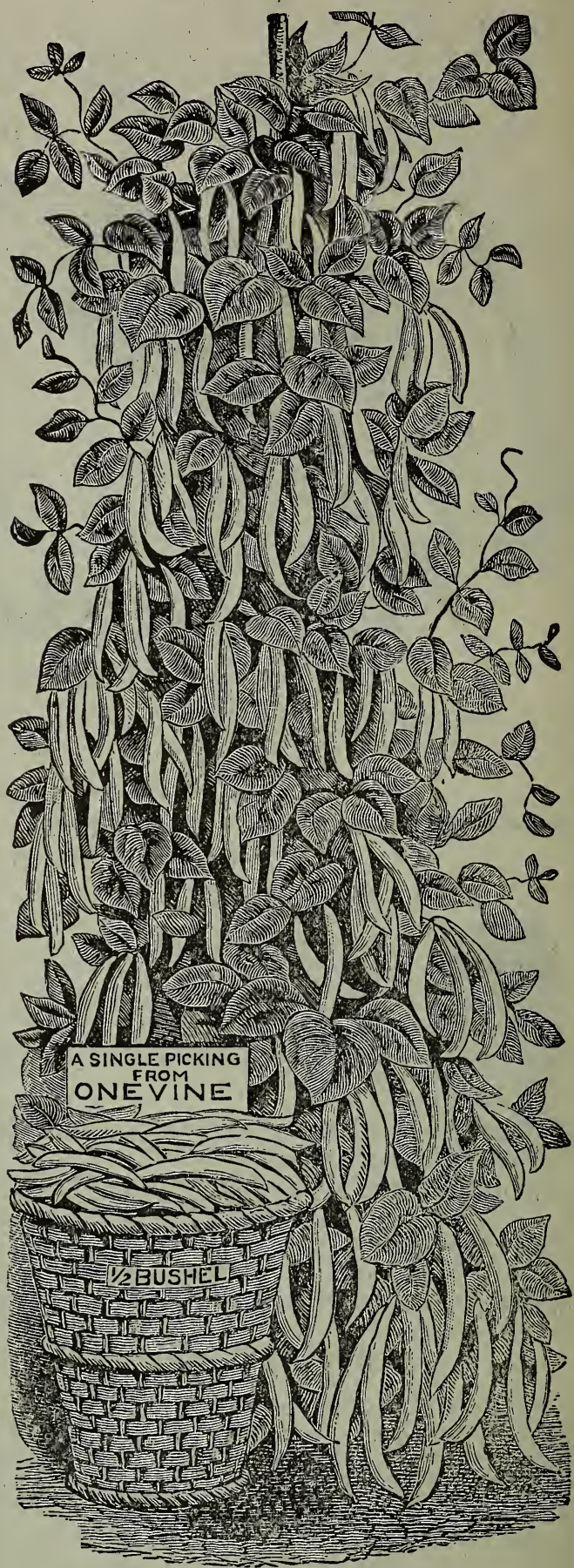

Kentucky Wonder.

\section{BEANS (Pole or Runners).}

Kentucky Wonder, or Old Homestead-We can recommend this as one of the earliest and most satisfactory of all Green Podded Pole Beans, and unsurpassed for using in the green state. It is enormously productive; the long, silvery green pods hanging in great clusters from top to bottom of the pole. This is the best and most popular bean for the market gardener, the pods being so showy and produce so abundantly. We can supply the White, Black and Brown Seeded Kentucky. Wonder Beans. They are adl good. $15 \mathrm{cts}$. pt.; 25 cts. at. 


\section{BEANS (Pole or Runners)--Continued}

They are more tender and require rather more care in culture than the Bush Beans and should be sown two weeks later. They succeed best in sandy loam, which should be liberally enriched with manure. Form hills from three to four feet apart; plant five or six beans in each hill, about two inches deep, leaving a space in the center for the pole. Limas will not grow until the weather and ground are warm; if planted early they are apt to rot in the ground. One quart makes 100 to 200 hills, according to size of the beans; 10 to 12 quarts will plant an acre. Add 10 cents per pint, 15 cents per quart, if sent by mail.

Large White Lima-A very popular variety, largely grown for market, 15 cts. pt.; 25 cts. qt.

Ford's Mammo'h Podded Lima-This is the result of twenty years' selection by a successful market gardener, and far surpasses in size and productiveness any other variety. Pods usually contain five to seven beans of most excellent quality. 15 cts. pt.; 30 cts. qt.

Extra Early Jersey Lima.-Of strong growth, maturing a good crop quite early. Pods usually contain three beans each. 15 cts. pt.; 30 cts. qt.

Extra Large Lima-The finest flavored of all shell beans. 15 cts. pt.; 25 cts. qt.

King of the Garden Lima-A vigorous grower, bearing profusely, the beans are large and of rich flavor. $15 \mathrm{cts}$. pt.; 25 cts. qt.

Dutch Case Knife-Early, productive, good for string or shell beans. 15 cts. pt.; 25 cts. qt.

Horticultural-(Wren's Egg or Speckled Cranberry)Early and best shell bean, productive and tender. 15 cts. pt.; 25 cts. qt.

Golden Carmine Pole-It is at least ten days earlier than the Horticultural, and the pods, which are stringless, are equally as large and more striking in appearance, as upon the approach of full size they become mottled, and streaked with an unusually bright carmine color on the golden yellow background. The pods are brittle, meaty and very tender, and remain so for a long time. 15 cts.pt.; 25 cts.qt.

White Creaseback-A green pod bean, exceedingly productive, pods five to six inches long, perfectly round, with a crease in the back, stringless, very fleshy, early, and of fine quality. 15 cts. pt.; 25 cts. qt.

Cut Short or Corn Hill-An old and popular variety, much used for planting among corn, excellent as a green shell or dry bean. 15 cts. pt.; 25 cts. qt.

Scarlet Runner-Ornamental variety with bright scarlet flowers, also a good string bean. 20 cts. pt.; 40 cts. qt.

Lazy Wife's-The pods grow from four to six inches long, entirely stringless, and of a rich buttery flavor when cooked. The pods remain green and retain their tender, rich flavor until ripe, excellent shell bean for winter use 15 cts. pt.; 25 cts. qt.

\section{SUGAR BEETS AND MANGEL WURZEL.}

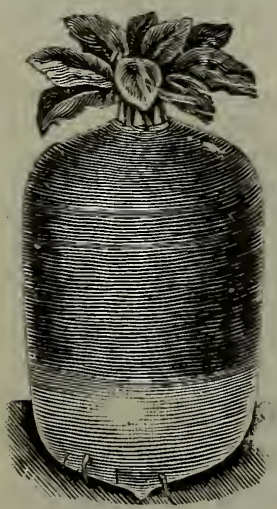
FOR STOCK FEEDING. - Lane's Improved Sugar Beet. - Large, hardy and very productive, 10 cts. oz.; 15 cts. $\frac{1}{4}$ lb.; 40 cts. lb.

Silesian Sugar Beet-Attains a large size and is highly valued for feeding, 10 cts. oz.; 15 cts. $\frac{1}{4}$ lb.; 40 cts. $1 \mathrm{~b}$.

Golden Tankard MangelBright, yellow. large, handsome heavy cropper, splendid quality 10 cts. oz.; 20 cts. $\frac{1}{4} \mathrm{lb}$; 50 cts. lb.

Mammoth Long Red Mangel-Very large and productive. 10 cts. oz.; 20 cts. $\frac{1}{4}$ lb.; 50 cts. lb.

\section{BEET (Runkel Rube, Ger.)}

Sow as early in spring as the ground can be worked, in light well-manured soil, in drills twelve inches apart, covering the seeds one inch deep and pressing the soil firmly over them. Thin out four inches apart for table beets, and eight to twelve inches for field beets, cultivate frequently. One ounce to 60 feet of drill, five to six pounds to the acre.

\section{TABLE VARIETIES.}

Crosby's Egyptian-An improved strain of the Egyptian Beet in great repute in Boston market. Much thicker than the original, quite as early, better color and quality, and smoother. 15 cts. oz.; 35 cts. $\frac{1}{4} \mathrm{lb}$; $\$ 1.25 \mathrm{lb}$.

Norwood Blood Turnip-Of good marketable size, very uniform, round and smooth. 15 cts. oz.; 35 cts. $\frac{1}{4} \mathrm{lb}$.; $\$ 1.25 \mathrm{lb}$.

Edmand's Improved-Tery fine turnip-shaped beet of round form, good size, dark red color and fine flavor. 15 cts. oz.; 35 cts. $\frac{1}{4} \mathrm{lb}$; $\$ 1.25 \mathrm{lb}$.

Early Eclipse - The best and most profitable very early variety of excellent form, dark color and tender quality. $15 \mathrm{cts} .0 \mathrm{z} . ; 30 \mathrm{cts}$. $\frac{1}{4} \mathrm{lb}$; $\$ 1.00 \mathrm{lb}$.

Egyptian-Extra early, flat turnip-shaped, deep red, tender and sweet. 15 cts. oz.; 30 cts. $\frac{1}{4}$ lb.; $\$ 1.00 \mathrm{lb}$.

Early Bassano-Flat, turnipshaped, light red. 10 cts. oz.; 25 cts. $\frac{1}{4}$ lb.; 90 cts. lb.

Dewing's Blood Turnip-Early, blood-red, good size, smooth and handsome. 15 cts. oz.; 35 cts. $\frac{1}{4}$ lb.; $\$ 1.25 \mathrm{lb}$.

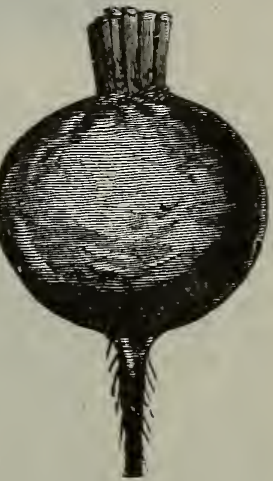

Early Blood Turnip-Early, dark-red, well-flavored, extra. 15 cts. oz.; 30 cts. $\frac{1}{4}$ lb.; $\$ 1.00 \mathrm{lb}$.

Improved Long Blood-Excellent late sort, dark and smooth. 10 cts. oz.; 25 cts. $\frac{1}{4}$ lb.; 90 cts. lb.

Detroit Red Turnip-Its small upright-growing tops, early maturing and the splendid shape and color of the roots make it popular with every one who plants it. Color of skin dark blood-red flesh, bright red, zoned with a lighter shade, very crisp, tender and sweet. $15 \mathrm{cts}$. oz.; 30 cts. $\frac{1}{4} \mathrm{lb}$; $\$ 1.00 \mathrm{lb}$.

Swiss Chard or Sea Kale-This does not form edible roots like the regular garden beets. It is grown for the leaf stalks and these practically combine two kinds of vegetables. The young leaves, when cooked, are by some considered more delicious than Spinach. $10 \mathrm{cts}$. oz.; 25 cts. $\frac{1}{4}$ lb.; 90 cts. lb.

Mixed Beets-This mixture will furnish your table with the very earliest beets, and continuous supply thereafter through the summer, fall and winter. 15 cts. oz.; 30 cts. $\frac{1}{4} \mathrm{lb}$; $\$ 1.00 \mathrm{lb}$.

\section{BROCCOLI (Spargel Kohl, Ger.)}

Resembles cauliflower, but hardier. Sow in a hot bed in May, and transplant to a rich mellow soil in early July. One ounce to one hundred yards of row.

Early White Cape-Heads medium, compact, creamy white, 25 cts. oz.; 90 cts. $\frac{1}{4} \mathrm{lb}$.

Early Purple Cape-Greenish-purple heads, hardy, good flavor. 25 cts. oz.; 90 cts. $\frac{11}{4} \mathrm{lb}$.

\section{BRUSSELS SPROUTS (Sprossen Kohl, Ger.)}

This plant grows two or three feet high and produces from the sides of the stalk numerous little sprouts one or two inches in diamater, resembling cabbage.

Dwarf Improved-A variety producing compact sprouts of excellent quality, $25 \mathrm{cts}$. oz.; $60 \mathrm{cts}$. $\frac{1}{4} \mathrm{lb}$; $\$ 1.75 \mathrm{lb}$. 


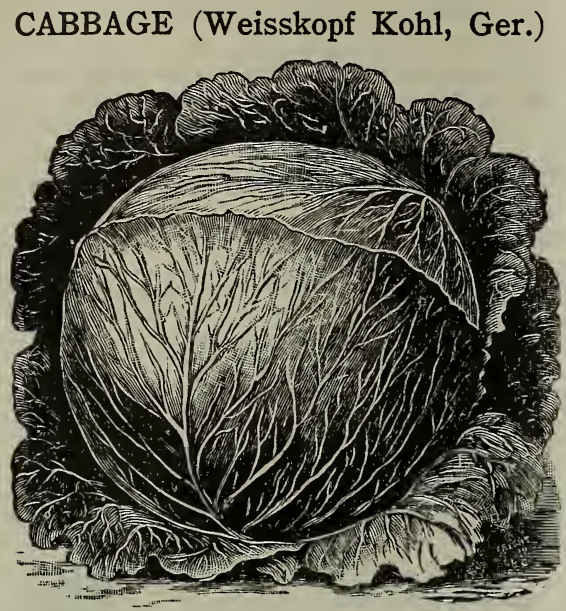

This vegetable requires a deep, rich, mellow soil, high manuring and good culture, in order to obta!n fine solid heads. For early use sow seeds of the early kinds in the hot bed, or in a box in the house, the last of January or early in February and transplant them in the open ground in April, in rows two feet apart and 18 inches between the plants in the row; or sow a bed of seed outside as soon as the soil can be worked, if you do not care for real early cabbage. These may be transplanted in about 4 weeks. For second early cabbage, sow in April and transplant in May. For late cabbage, sow in May and transplant in July, in rows three feet apart and two feet apart in the row. In transplanting cabbage or cauliflower, it is important that the plant is set down to the first leaf that the stem may not be injured in case of frost. One ounce of seed produces 1,500 to 2,000 plants and sows an area of about 40 square feet.

Louisville Early Drumhead-Originated in this market and is now the principal market variety and cannot be surpassed. Early heads of very large size and very solid, the best and surest heading for all purposes and will stand the entire summer without bursting. 20 cts. oz.; 50 cts. $\frac{1}{4} \mathrm{lb} . ; \$ 1.75 \mathrm{lb}$.

Glory of Enkhuizen-One of the earliest with large solid heads, fine ribbed and first quality. The globe shaped outer leaves are very small, which admits of close planting. A money maker for market gardeners. 25 cts. oz.; 75 cts. $\frac{1}{4} \mathrm{lb} . ; \$ 2.50 \mathrm{lb}$.

Early Spring (The Earliest Flat Headed Variety) - It is of the type of the early "Allhead," resembling it in habit and growth, but is smaller and is nearly as early as the Wakefield. It is round in shape, slightly flattened, very solid, even before the cabbage attain their mature size. 20 cts. oz.; 50 cts. $\frac{1}{4} \mathrm{lb}$.; $\$ 1.75 \mathrm{lb}$.

Danish or Hollander-Small size, solid heads, one of the best for shipping. $25 \mathrm{cts}$. oz.; 75 cts. $\frac{1}{4} \mathrm{lb}$.; $\$ 2.50 \mathrm{lb}$.

Charleston Wakefield-Much larger than the Old Wakefield and only a few days later. Favorite for Gardeners. 20 cts. oz.; 50 cts. $\frac{1}{4}$ lb.; $\$ 1.75$ lb.

All Head Early-An early variety, deep flat heads; remarkably solid in quality, tender, uniform in shape and size, compact growth All Head is also valuable for a late Winter cabbage. 20 cts. oz.; 50 cts. $\frac{1}{4} \mathrm{lb}$.; $\$ 1.75 \mathrm{lb}$.

Early Winningstadt-A very early variety in size close to the Wakefield, heads large, decidedly conical, leaves bright green, heads solid and hard. 15 cts. oz.; 40 cts. $\frac{1}{4}$ lb.; $\$ 1.40 \mathrm{lb}$.

Surehead-A large variety producing large, round, flattened heads. It is all head and always sure to head. 20 cts. oz.; 50 cts. $\frac{1}{4} \mathrm{lb}$; $\$ 1.75 \mathrm{lb}$.

\section{CABBAGE-Continued.}

Early Jersey Wakefield-The very best early variety, conical shape, solid, sure heading. 20 cts. oz.; 50 cts. $\frac{1}{4}$ lb.; $\$ 1.75 \mathrm{lb}$.

Henderson's Early Summer-The best large early cabbage, globular shape, a popular variety amongst market gardeners. 20 cts. oz.; 50 cts. $\frac{1}{4}$ lb.; $\$ 1.75 \mathrm{lb}$.

Early Dwarf York-Early and fine flavored. 15 cts. oz.; 50 cts. $\frac{1}{4}$ lb.; $\$ 1.50 \mathrm{lb}$.

Early Large York-Early and much larger than the Dwarf York. 15 cts. oz.; 50 cts. $\frac{1}{4} \mathrm{lb}$.; $\$ 1.50 \mathrm{lb}$.

All Seasons-Early variety, heads large and solid. 20 cts. oz.; 50 cts. $\frac{1}{4} \mathrm{lb}$.; $\$ 1.75 \mathrm{lb}$.

Early Dwarf Flat Dutch-Heads solid, good flavor, and excellent variety. 15 cts. oz.; 50 cts. $\frac{1}{4} \mathrm{lb}$.; $\$ 1.50 \mathrm{lb}$.

Premium Flat Dutch-(Select Stock)-Heads large and very solid, they open white and crisp, are tender and well flavored; for the Winter market it has no equal. $15 \mathrm{cts}$. oz.; 50 cts. $\frac{1}{4} \mathrm{lb}$; $\$ 1.50 \mathrm{lb}$.

Fottler's Improved Brunswick-A rapid grower has large, solid heads, and excellent second early or late variety. 20 cts. oz.; 50 cts. $\frac{1}{4} \mathrm{lb}$.; $\$ 1.75 \mathrm{lb}$.

Large Late Drumhead-Large, solid and tender, an excellent Winter cabbage. 15 cts. oz.; 50 cts. $\frac{1}{4} \mathrm{lb}$.; $\$ 1.50 \mathrm{lb}$.

Volga - It is remarkable for uniformity and solidity, the heads being of about equal size and weighing from 12 to $15 \mathrm{lbs}$. each. It is extremely hardy, remarkably quickgrowing, maturing heads fully two weeks earlier than any of our late-growing kinds. 20 cts. oz.; 65 cts. $\frac{1}{4} \mathrm{lb}$.; $\$ 2.00 \mathrm{lb}$.

Red Dutch-The old standard variety for pickling. 20 cts. oz.; 60 cts. $\frac{1}{4} \mathrm{lb}$.; $\$ 2.00 \mathrm{lb}$.

Improved Drumhead Savoy-The finest flavored Winter cabbage, large, round, solid heads. 20 cts. oz.; 50 cts. $\frac{1}{4} \mathrm{lb} . ; \$ 1.75 \mathrm{lb}$.

\section{CARROT (Moehren, Ger.)}

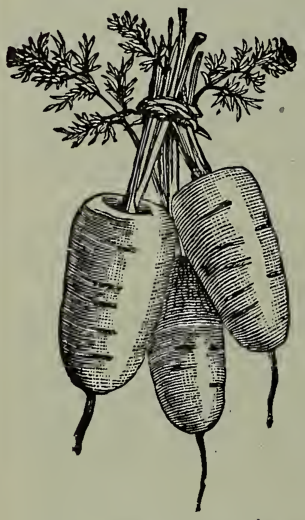

The carrot grows best in a light sandy loam, well manured and cultivated. Sow as early as the ground can be worked, in drills 10 inches apart for the small sorts and 14 inches apart for the larger kinds, thin out to 5 or 6 inches apart in the rows. One ounce of seed will sow 150 feet of drill, 4 lbs. to the acre.

Early French Forcing-The earliest variety grown, small, tender, fine quality. 15 cts.' oz.; 40 cts. $\frac{1}{4} \mathrm{lb}$.; $\$ 1.40 \mathrm{lb}$.

Early Scarlet Horn-An excellent table sort, fine color and flavor. 15 cts. oz.; 40 cts. $\frac{1}{4}$ lb.; $\$ 1.25 \mathrm{lb}$.

Half Long Stump Rooted-A fine grained table variety, of fair size and good color. $15 \mathrm{cts} .0 \mathrm{z}$; $40 \mathrm{cts} . \frac{1}{4} \mathrm{lb}$; $\$ 1.25 \mathrm{lb}$.

Danver's Half Long - The most desirable variety for the main crop, productive and keeps well. $15 \mathrm{cts}$. oz.; 40 cts. $\frac{1}{4} \mathrm{lb}$; $\$ 1.25 \mathrm{lb}$.

Guerande or Oxheart-Extra fine quality, beautiful shape and very productive. Color, a rich orange. In length it is intermediate between the Danvers and Short Horn Carrot. 15 cts. oz.; 40 cts. $\frac{1}{4}$ lb.; $\$ 1.25 \mathrm{lb}$

Chantenay-An early one-half long, stump-rooted variety of the best quality 15 cts. oz.; 40 cts. $\frac{1}{4}$ lb.; $\$ 1.25 \mathrm{lb}$.

Intermediate - The roots grow regular and smooth, good size and very productive. 15 cts. oz.; 40 cts. $\frac{1}{4} \mathrm{lb}$.; $\$ 1.25 \mathrm{lb}$.

Improved Long Orange-Large, heavy copper and excellent keeper. 15 cts. oz.; 40 cts. $\frac{1}{4}$ lb.; $\$ 1.25 \mathrm{lb}$.

Large White Belgian-Large, long rooted variety, valuable for feeding stock. $10 \mathrm{cts}$. oz.; $25 \mathrm{cts} . \frac{1}{4} \mathrm{lb}$; 75 cts. lb. 
CAULIFLOWER (Blumenkohl, Ger.)

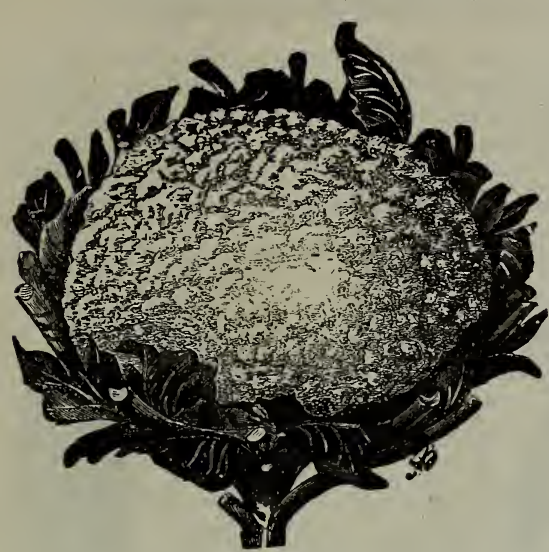

The culture of cauliflower is similar to cabbage. It delights in a $\mathrm{r} \mathrm{i} \mathrm{c} \mathrm{h}$ moist soil and in dry $\mathrm{s}$ e a $\mathrm{s}$ on $\mathrm{s}$ should be abundantly wa tered especially when heading. Sow seeds in the hot bed in January or February, and transplant the plants two or three inches apart in boxes, until such time as they are safe to be planted in the open ground. Set the plants 2 feet by 18 inches apart. When heading tie the outside leaves loosely over the head to protect it from the sun.

One ounce gives 2000 plants.

Henderson's Early Snowball-A very early dwarf variety, producing magnificent white heads of the. finest quality. Its compact habit of growth renders it a pecu.iarly profitable variety to force under glass, and it does equally well for late planting. $20 \mathrm{cts}$ pkt.; $80 \mathrm{cts}$. $\frac{1}{4} \mathrm{oz}$.; $\$ 2.75 \mathrm{oz}$.

Earliest Dwarf Erfurt-This is the choicest, heads of the largest size, snowy whiteness, compact and beautiful form. 20 cts. pkt.; 80 cts. $\frac{1}{4}$ oz.; $\$ 2.75 \mathrm{oz}$.

Danish Giant or Dry Weather-A large heavy sort, maturing soon after our Earliest Dwarf Erfurt. It is without exception the best and surest heading of all for summer use. 20 cts. pkt.; 80 cts. $\frac{1}{4}$ oz.; $\$ 2.75$ per oz.

Early Paris-A good standard variety. $20 \mathrm{cts} . \frac{1}{4} \mathrm{oz}$; 60 cts. oz.

\section{CELERY (Sellerie, Ger.)}

Sow in a hot bed in March, and as soon as the plants are three inches high, transplant into a temporary bed in the open air, 4 inches apart. The plants may remain here until the first of July, and then remove to the trenches. The trenches ought to be a foot wide and deep and 5 feet apart. Spread a layer of well rotted manure in the bottom of the trench and dig in. Set the plants in the bottom of the trench 6 or 8 inches apart. As they grow, cultivate with the hoe and gradually earth them up, and by the end of September they will be blanched sufficiently for use. Never earth up while the plants are wet, and be careful not to let the soil get into the heart of the plant. Water carefully in dry weather. One ounce will produce about 4,000 plants.

Giant Pascal-A superior keeping sort. The stalks are very large, thick, solid, crisp and of a rich nutty flavor. It blanches easily and retains its freshness a long time. 15 cts. oz.; 50 cts. $\frac{1}{4}$ lb.; $\$ 1.50$ lb.

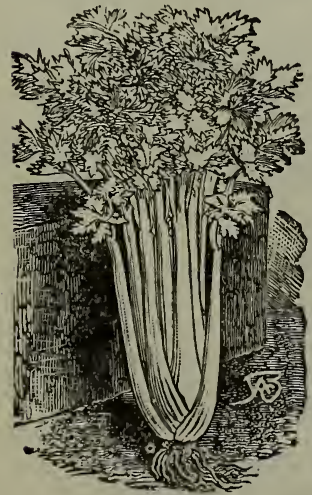

Golden Self-Blanching-Close, compact, perfectly solid, crisp, well-flavored and excellent keeper. 50 cts. oz.; $\$ 1.50 \frac{1}{4} \mathrm{lb}$.

Dwarf Golden Heart-Its handsome color, medium size, fine flavor and good keeping qualities render it the leading sort. 15 cts. oz.; 50 cts. $\frac{1}{4} \mathrm{lb}$.; $\$ 1.50 \mathrm{lb}$.

White Plume-A crisp, solid variety, with a pleasant, nutty flavor, almost self-blanching, the stocks requiring very little earthing up Very ornamental for the table. 20 cts. oz.; 60 cts. $\frac{1}{4} \mathrm{lb}$; $\$ 1.75 \mathrm{lb}$.
Giant White Solid-Fine, large size, tall and of stiff growth. 15 cts. oz.; 50 cts. $\frac{1}{1}$ lb.; $\$ 1.50 \mathrm{lb}$.

Boston Market-Dwarf-branching habit, solid crisp, well-flavored. 15 cts. oz.; 50 cts. $\frac{1}{4}$ lb.; $\$ 1.50 \mathrm{lb}$.

Paris Golden Yellow-Close, compact growth, golden yellow color. The stock is solid and crisp and a good keeper. 50 cts. oz.; $\$ 1.50 \frac{1}{4} \mathrm{lb}$.

Celeraic or Turnip Rooted-The round, solid roots of this variety are used for flavoring. $15 \mathrm{cts} . \mathrm{oz} . ; 40 \mathrm{cts}$. lb.; $\$ 1.25 \mathrm{lb}$

Soup or Flavoring - $50 \mathrm{cts}$. lb.

\section{CORN SALAD (Ackersalat, Ger.)}

Used as a salad. Sow as early in spring as the ground can be worked, in drills 12 inches apart, and cover lightly. For winter and spring use, sow in September, and winter over in cold frames.

Large Seeded-The standard variety. 10 cts. oz.; 25 cts. $\frac{1}{4}$ lb.; 60 cts. lb.

\section{CORN, Sweet (Mais, Ger.)}

The planting of corn should begin as early in April as the weather will permit, and kept up at intervals throughout the season so as to keep up a constant supply The first planting should be made of the "extra early" sorts, and the last planting of the Improved Evergreen Sugar, and you will not fail to have a constant supply from the middle of June to the middle of October. One quart plants 200 to 300 hills, eight to ten quarts for an acre Add 10 cents per pint, 15 cents per auart, if sent by mail.

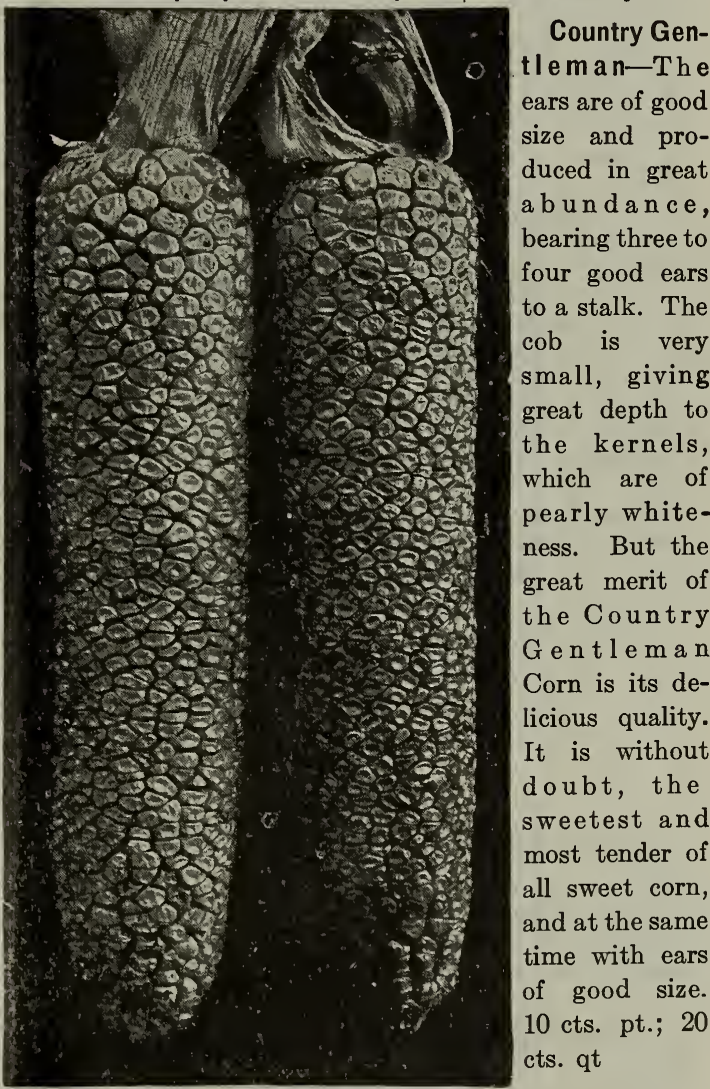

Country Gentleman.

Golden Bantam-This new corn is very early, hardy and sweet. Grains, when dry, a deep yellow color. On our trial grounds it gave two good ears to the stalk. $15 \mathrm{cts}$ pt.; 25 cts. qt.

"Peep 0'Day"-Earlier than any other; tender, sweet. The cob is white, kernels pearly white, ears delicate and dainty, exceptionally good for early market or home consumers. No market gardener can afford to be without

Peep o' Day. It will prove a money-maker in any garden. 15 cts. pt.: 25 cts. qt. 


\section{CORN, Sweet-Continued}

White Mexican-White Mexican is a heavy yielding, early maturing Sweet Corn. It ranks in class with White Cob Cory and is a better yielder. Height, 4 feet; ear about $6 \frac{1}{2}$ inches long; quality good. 15 cts. pt.; 25 cts. qt.

Premo Early Sweet-Premo can be planted fully as early as the Adams, for the young plants withstand slight frosts, while the other varieties are tender and the seeds will rot if planted before the soil becomes warm. The stalks grow about five feet high, and are very vigorous, generally bearing two well-developed ears to a stalk. 15 cts. pt.; 25 cts. qt.

Zig Zag Evergreen-This variety of Evergreen Sweet Corn is one of the best for private use, market gardeners and canners. It is of extra quality, very sweet and juicy in the green state. It ripens about same time as Stowell's Evergreen, and is superior to that well-known variety in sweetness and flavor. 10 cts. pt.; 20 cts. qt.

Extra Early Cory-Second earliest variety in cultivation, producing good sized ears, fine quality and productive. 10 cts. pt.; 20 cts. qt.

Extra Early Adams-An old standard white corn, ready for table sixty days after germination, not a sweet corn. 10 cts. pt.; 15 cts. qt.

Kendel's Giant-Very early for so large-eared a sort; fine quality. 15 cts. pt.; 25 cts. qt.

Early Minnesota-An early sort, of dwarf habit. $10 \mathrm{cts}$. pt.; 20 cts. qt.

Crosby's Early-One of the finest early sweet corns, productive and of excellent quality. $10 \mathrm{cts}$. pt.; 20 cts. qt.

White Cory-Much the same as the Red Cory, with the great advantage of a white cob. 10 cts. pt.; 20 cts. qt. Egyptian-A late sort, ripening with Stowell's, largely used for canning. 10 cts. pt.; 20 cts. qt.

Perry's Hybrid-Early and of large size, good for market. 10 cts. pt.; 20 cts. qt.

White Evergreen-This valuable sugar Corn is a distinct improvement over the old Stowell's Evergreen. It produces handsome ears, well filled with deep grains of pure snowy whiteness, and of the most delicious sweetness. 15 cts. pt.; 25 cts. qt.

Stowell's Improved Evergreen-The standard late sort, large ears, remaining long green. 10 cts. pt.; 20 cts. qt. Mammoth Sugar-Large, long, full ears, of excellent flavor. 10 cts. pt.; 20 cts. qt.

Adam's Early-Old standard sort. 10 cts. pt.; 15 ets.nt.

Black Mexican-Its merit is its sweetness. 10 cts. pt.; 20 cts. qt. Shaker's Early-The kernels are large, of pearly whiteness and delicious flavor. It is a great favorite with market gardeners. $10 \mathrm{cts}$. pt.; 20 cts. qt.

\section{SEED POP CORN}

White Pearl-Our common market variety. 10 cts. pt.; $20 \mathrm{cts}$. qt.

White Rice-A handsome variety, kernels long and pointed, very prolific 10 cts. pt.; 20 cts. qt.

Queen's Golden-The stalks grow six feet high and the large ears are produced in abundance, it pops perfectly white. 10 cts. pt.; 20 cts. qt.

We always have in stock a large supply of

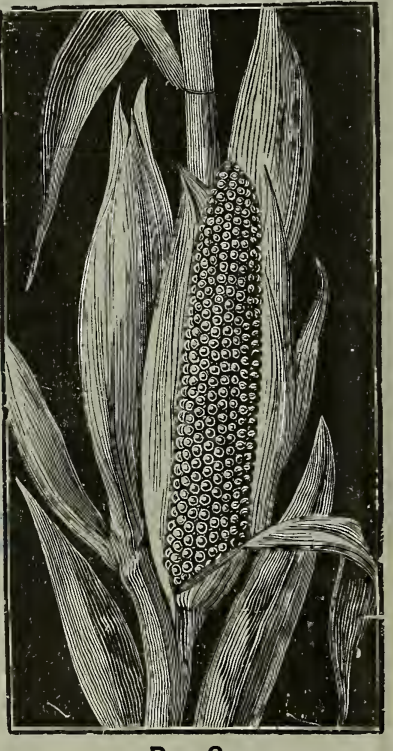

old corn for popping, and are prepared to fill all orders at market prices.

\section{SWEET CORN FOR FODDER.}

There is nothing better for green feed, or curing for winter, than sweet corn. Cattle highly relish it, and when fed on it, keep in fine condition and give an abundance of milk. Also excellent for soiling. Sow thickly in drills or broadcast at the rate of two to three bushels per acre 10 cts. lb.; 50 cts. pk. Subject to market change.

\section{CUCUMBERS (Gurken, Ger.)}

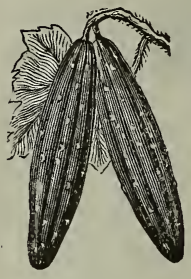

As soon as the weather becomes settled and warm, plant in hills from four to six feet apart each way, with eight or ten seeds in each hill, cover half an inch deep, smoothing the hill off with the hoe. Keep the soil well stirred, and when the plants are out of danger of insects, leave three or four plants to the hill. For pickles, plant from the first of June to the first of August. The fruit should be gathered when large enough whether required for use or not, as, if left to ripen on the vines, it destroys their productiveness. One ounce for 50 hills, 1 to $2 \mathrm{lbs}$. per acre.

Davis' Perfect-As is well known to many persons, Mr. Davis is the originator of the Davis Wax Bean, and Grand Rapids Lettuce. His perfect Cucumber is not only an ideal green-house variety, but a profitable one for truck gardeners to grow out-of-doors. Color, dark glossy green. This cucumber is a very shy seeder. The few seeds in each one are so small and tender as to be hardly noticeable when eating. 15 cts. oz.; 40 cts. $\frac{1}{4} \mathrm{lb}$.; $\$ 1.25 \mathrm{lb}$.

Cincinnati Pickle-The fruit of this variety is of medium length, with large and prominent spines, and begins to set while the vines are quite young; color is a deep green, the ideal for a pickle. 10 cts. oz.; 30 cts. $\frac{1}{4} \mathrm{lb}$; $90 \mathrm{cts}$. lb.

Japanese Climbing-Is strong, vigorous and prolific, fruit 10 to 12 inches long, of a dark green color, delicious flavor. The vines are proof against mildew, never suffering from wet weather or insects. 15 cts. oz.; 40 cts. $\frac{1}{4} \mathrm{lb}$.

Cool and Crisp-This variety is inclined to taper off at the stem end, and is generally a little pointed at the other end also; is the most desirable shape for pickles. 10 cts. oz.; 25 cts. $\frac{1}{4}$ lb.; 80 cts. lb.

Extra Early Russian-The earliest, hardy, prolific; excellent for small pickles. 10 cts. oz.; 25 cts. $\frac{1}{4}$ lb.; 80 cts. lb.

Early Cluster-A short prickly variety, bearing in clusters, very prolific. 10 cts. oz.; 25 cts. $\frac{1}{4}$ lb.; 80 cts. lb.

Early Frame-Early, medium length, good for forcing. 10 cts. oz.; 25 cts. $\frac{1}{4}$ lb.; 80 cts. lb.

Improved White Spine-Medium length, crisp, well flavored, prolific. One of the most popular varieties grown. 10 cts. oz.; 30 cts. $\frac{1}{4} \mathrm{lb}$; 90 cts. lb.

Improved Long Green-Very popular, late variety, dark green, crisp, tender and well flavored. $10 \mathrm{cts}$. oz.; $30 \mathrm{cts}$. $\frac{1}{4} \mathrm{lb}$; $90 \mathrm{cts}$. lb.

Jersey Pickling-The best variety for pickling, short straight, dark green, fine quality, great bearer. 10 cts. oz.; 30 cts. $\frac{1}{4}$ lb.; 90 cts. lb.

Green Prolific-One of the best,for pickles, very uniform in growth, extremely productive and its flavor makes it desirable also for a table variety. 10 cts. oz.; 30 cts. $\frac{1}{4}$ lb.; 90 cts. lb. 


\section{CUCUMBERS-Continued}

Nichol's Medium Green-Early; good for forcing or pickles, dark green, crisp, very prolific, straight and smooth, in length between the White Spine and Long Green, a decided acquisition 10 cts. oz.; 30 cts. $\frac{1}{4} \mathrm{lb}$; 90 cts. lb.

West India Gherkin-A small green pickling sort, used for pickling only. $15 \mathrm{cts}$. oz.; $50 \mathrm{cts}$. $\frac{1}{4} \mathrm{lb}$.

\section{CRESS or PEPPER GRASS (Kresse, Ger.)}

Well-known pungent salad, can be used alone or with lettuce. Requires to be sown thickly (curling very slightly) at frequent intervals to keep up a succession, as it soon runs to seed.

Extra Double Curled-Fine pungent flavor, extensively used as a salad. 10 cts. oz.; 20 cts. $\frac{1}{4} \mathrm{lb}$; 50 cts. lb.

Water Cress-Hardy acquatic perennial, growing readily on the banks of streams or ponds. 35 cts. oz.; $\$ 1.00 \frac{1}{4} \mathrm{lb}$.

\section{ENDIVE (Endivien, Ger.)}

Sow in June or July, and transplant 8 or 10 inches apart in rows, 15 inches apart. Used as a salad, and requires to be blanched by tieing the leaves together at the top and placing boards to exclude the light. One ounce of seed to 150 feet of drill.

Green Curled-One of the best, dark green, finely curled 15 cts. oz.; 45 cts. $\frac{1}{4} \mathrm{lb}$.; $\$ 1.50 \mathrm{lb}$.

Moss Curled-Beautifully and densely curled, very ornamental. 15 cts. oz.; 45 cts. $\frac{1}{4} \mathrm{lb}$.; $\$ 1.50 \mathrm{lb}$.

Batavian Broad-Leaved-A large summer variety, very productive. $15 \mathrm{cts}$. oz.; $40 \mathrm{cts} . \frac{1}{4} \mathrm{lb}$; $\$ 1.25 \mathrm{lb}$.

\section{EGG PLANT (Eierpflanze, Ger.)}

Sow seeds in a hot-bed in March in the same manner as tomatoes. As they are very susceptible to cold they should not be transplanted to the open ground until the weather is quite warm. Set the plants two feet apart each way. One ounce of seed will produce 1,000 plants.

Long Purple-Early,deep purple, oblong, hardy, productive, excellent, color variable. 20 cts. oz.; 75 cts. $\frac{1}{4}$ lb.; $\$ 2.50 \mathrm{lb}$.

New York Improved-One of the best, very large, fine quality. 30 cts. oz.; $\$ 1.00 \frac{1}{4} \mathrm{lb}$.

Black Beauty-As large as the New York Improved but about ten days earlier; very rich purplish black. 30 cts. oz.; $\$ 1.00 \frac{1}{4} \mathrm{lb}$.

\section{KOHL RABI (Kohl-Rabi, Ger.) (TURNIP CABBAGE)}

When young and tender they are fine for table use, when matured they will keep well and are excellent for Winter feeding to stock. For early use sow in hot-bed transplant and cultivate like early cabbage. For Winter use sow in the middle of June or first of July in rows 18 inches apart. One ounce of seed for 1,500 plants.

Early White Vienna-Flesh white and tender, 20 cts oz.; 50 cts. $\frac{1}{4}$ lb.

Early Purple Vienna-An excellent sort, later than the white. 20 cts. oz.; 50 cts. $\frac{1}{4} \mathrm{lb}$.

\section{LEEK (Lauch, Ger.)}

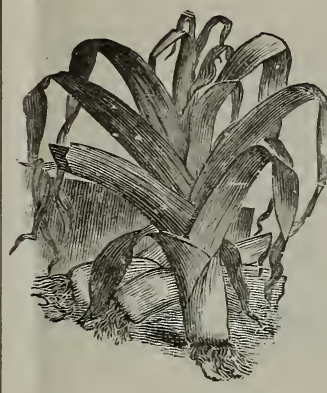

The Leek is generally considered superior to the Onion for soups, it is very hardy and easily cultivated. Sow in drills a foot a part, in April, and transplant in July, in rows fifteen inches apart, and six inches from plant to plant. They should be set five inches deep, in rich, moist soil. One ounce will produce about 1,000 plants

Large Rouen-One of the best, large and broad, of very mild, pleasant flavor. 15 cts. oz.; 40 cts. $\frac{1}{4} \mathrm{lb} . ; \$ 1.25 \mathrm{lb}$.

American Flag-Hardy, useful sort for general use. 15 cts. oz.; 40 cts. $\frac{1}{4} \mathrm{lb}$; $\$ 1.25 \mathrm{lb}$.

\section{LETTUCE (Lettich-Salat, Ger.)}

It requires rich, moist soil, clean cultivating and plenty of water. This will give the quick growth on which depends its appearance, tenderness and flavor. Sow in a hot-bed in early Spring, as soon as the ground can be well worked, transplant in good rich ground, to rows 18 inches apart, and 8 to 10 inches in the rows. For a later supply, plant every two weeks from the middle of April until July, choosing varieties according to their heat resistance, and their tendency to remain in condition without seeding. One ounce of seed for 2,500 plants.

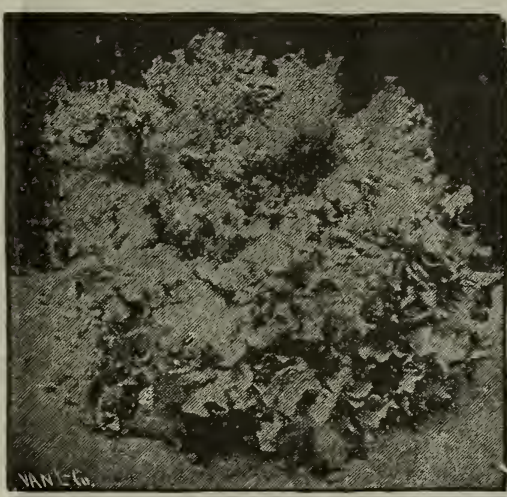

Grand Rapids Forcing-It is of handsome appearance, a strong grower, and not apt to rot, and will keep from wilting longer while exposed for sale than any other sort. It matures two weeks earlier than Tennis Ball. 15 cts. oz.; 30 cts. $\frac{1}{4}$ lb.; 90 cts. lb.

\section{Grand Rapids Forcing Lettuce.}

Cincinnati Market-The best forcing variety known and a favorite with all gardeners. Large, pale green leaves, exceedingly crisp and tender and a shy seeder. $15 \mathrm{cts.}$ oz.; 40 cts. $\frac{1}{4} \mathrm{lb}$.

Buttercup-New variety from Germany, tender and delicate flavor, early hard-heading, beautiful foliage, good either for summer or winter. $15 \mathrm{cts}$. oz.; 40 cts. $\frac{1}{4} \mathrm{lb}$; $\$ 1.00 \mathrm{lb}$.

Early Curled Silesian-Very early and well-known sort, 15 cts. oz.; 30 cts. $\frac{1}{4}$ lb.; 80 cts. lb.

Early Prize Head-Very large, crisp; tender, fine flavored, hardy, slow to seed. 15 cts. oz.; 30 cts. $\frac{1}{4} \mathrm{lb}$; 80 cts. lb.

Black Seeded Simpson-Like the ordinary Curled Simpson, it does not properly form a head, but a compact mass of leaves and differs in being light colored, the leaves being almost white, stands the summer heat excellently, and attains a size nearly double that of Curled Simpson. 15 cts. oz.; 30 cts. $\frac{1}{4}$ lb.: $\& 0$ cts. lb. 


\section{LETTUCE-Continued}

Deacon or. Nonpariel-This is a fine market variety, crimped, curled and well-formed heads, withstands the heat of summer well. $15 \mathrm{cts}$. oz.; $35 \mathrm{cts}$. $\frac{1}{4} \mathrm{lb}$.; $\$ 1.00 \mathrm{lb}$.

California Cream Butter-This variety forms round, solid heads of good size, medium early and one of the best summer sorts. 15 cts. oz.; 35 ets. $\frac{1}{4}$ lb.; $\$ 1.00 \mathrm{lb}$.

Cos or Romaine-Has no equalfor quality. Forms long, conical heads, which if tied up, blanch pure white and make solid heads as crisp as celery stalks. 15 cts. oz.; 35 cts. $\frac{1}{4} \mathrm{lb}$.; $\$ 1.00 \mathrm{lb}$.

Salamander-Large, solid heads, bright green in color, leaves thick smooth and tender, does not rapidly run to seed One of the best of the head lettuce. $15 \mathrm{cts} . \mathrm{z}$; 35 cts. $\frac{1}{4} \mathrm{lb} . ; \$ 1.00 \mathrm{lb}$.

Immensity-A gigantic variety, with an enormous solid head of the finest quality, even the outer leaves being tender, It is one of the slowest to run up to seed that we have ever seen, and maintains that crispness of texture and sweetness of flavor that will surely make it popular. 15 cts. oz.; 35 cts. $\frac{1}{4}$ lb.; $\$ 1.00 \mathrm{lb}$.

Big Boston-This variety resembles the well-known Boston Market Lettuce but produces heads almost double the size and matures a week later. $15 \mathrm{cts}$. oz.; $35 \mathrm{cts}$. $\frac{1}{4} \mathrm{lb}$.; $90 \mathrm{cts}$. lb.

Early Curled or White Seeded Simpson-Does not head, but forms a compact, close mass of leaves, excellent for forcing. 15 cts. oz.; 30 cts. $\frac{1}{4} \mathrm{lb}$; 80 cts. lb.

Black Seeded Tennis Ball-Solid, dark green heads, very hardy, one of the best for out-door growing, crisp and tender. 15 cts. oz.; 30 cts. $\frac{1}{4}$ lb.; 80 cts. lb.

White Seeded Tennis Ball-A fine early sort, small heads, very hardy, valuable to grow in cold frames in winter. 15 cts. oz.; 30 cts. $\frac{1}{4}$ lb.; 80 cts. lb.

Boston Market-The best forcing head sort, very compact, and is beautiful white and crisp. 15 cts. oz.; 35 cts. $\frac{1}{4} \mathrm{lb} . ; \$ 1.00 \mathrm{lb}$.

Improved Hanson-A splendid out-door lettuce, heads very close, solid and large, crisp, tender, sweet, green outside, white within. 15 cts. oz.; 35 cts. $\frac{1}{4} \mathrm{lb}$.; $\$ 1.00 \mathrm{lb}$.

Oak Leaved-Very distinct, excellent for summer use and for growing in the south, as it resists the greatest heat. 15 cts. oz.; 35 cts. $\frac{1}{4}$ lb.; $\$ 1.00 \mathrm{lb}$.

Paris White Cos-The best of the Cos varities, with long upright leaves, blanches readily when tied up. 15 cts. oz.; 30 cts. $\frac{1}{4}$ lb. lb.; $\$ 1.00$ lb.

Philadelphia Butter or Early White Head-A thickleaved, smooth lettuce, round dark green leaves, formed into a very solid, round head; stands a long time without running to seed. The inner leaves blanch a rich yellow; quality first class. 15 cts. oz.; 35 cts. $\frac{1}{4}$ lb.; $\$ 1.00 \mathrm{lb}$.

Denver Market-An early variety in head lettuce, either for forcing or open ground, it forms large solid heads of light green color and is very slow to go to seed. $15 \mathrm{cts}$. oz.; 30 cts. $\frac{1}{4}$ lb.; $\$ 1.00 \mathrm{lb}$.

Lettuce Mixture-All sorts. It can not fail to please. Will give a succession of good lettuce throughout the season. A fine contrast to our Radish Mixture, when planted along side of it. $15 \mathrm{cts}$. oz.; $30 \mathrm{cts} . \frac{1}{4} \mathrm{lb} . ; \$ 1.00 \mathrm{lb}$.

\section{MELON, WATER (Wassermelone, Ger.)}

Water Melons require the same treatment and soil as described for the Musk Melon, but being more tender, should be given a southern exposure if possible. The hills should be eight feet apart. One ounce for 30 hills, about 5 lbs. for an acre.
Triumph-Very prolific, early and of uniformly large size, and fine flavor. A good shipper. $10 \mathrm{cts}$. oz.; $20 \mathrm{cts}$. $\frac{1}{4} \mathrm{lb}$.; 60 cts. lb.

Florida Favorite-Of medium size, very prolific and unexcelled as a table variety. 10 cts. oz.; 25 cts. $\frac{1}{4} \mathrm{lb}$.; 70 cts. lb.

Black Spanish-Round, dark green, flesh scarlet, with delicious sweet flavor. $10 \mathrm{cts}$. oz.; 20 cts. $\frac{1}{4}$ lb.; 60 cts. lb.

Cuban Queen-A very fine variety, growing to great size, flesh bright red, very solid and sweet. Enormously productive and an excellent keeper. 10 cts. oz.; 20 cts. $\frac{1}{4} \mathrm{lb}$. $60 \mathrm{cts}$. lb.

Kolb's Gem — Light green, nearly round, averaging thirty to fifty pounds in weight, flesh bright red, rich and sweet, a good shipper. $10 \mathrm{cts}$. oz.; 20 cts. $\frac{1}{4}$ lb.; $60 \mathrm{cts}$. lb.

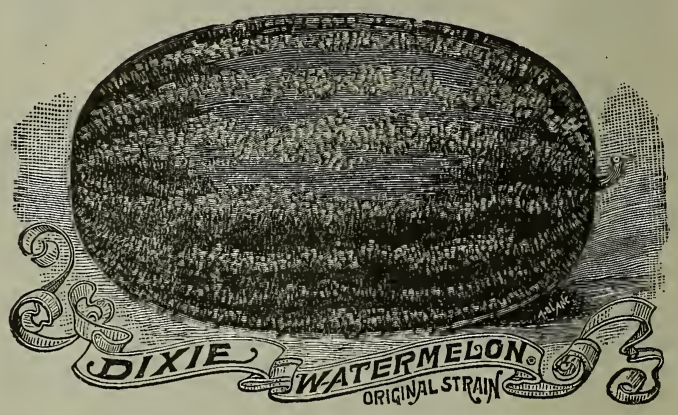

Dixie-Of excellent merits, recommended as best shipping melon grown, being even larger, earlier and more productive than the Kolb Gem. 10 cts. oz.; 20 cts. $\frac{1}{4}$ lb.; 60 cts. lb.

Gypsy or True Georgia Rattlesnake-Very large, long and smooth and distinctly striped, flesh bright scarlet, a favorite shipping melon in the south. 10 cts. oz.; 20 cts. $\frac{1}{4} \mathrm{lb}$; $60 \mathrm{cts}$. lb.

Mammoth Ironclad-Of large size and great weight, flesh deep red and of delicious flavor. 10 cts. oz.; 20 cts. $\frac{1}{4} \mathrm{lb}$; $60 \mathrm{cts}$. l.b.

Phinney's Early-Productive, early and finely flavored, red flesh. 10 cts. oz.; 20 cts. $\frac{1}{4}$ lb.; 60 cts. lb.

Peerless or Ice Cream-Of medium size, thin rind, light green, flesh scarlet, solid to center and sweet. $10 \mathrm{cts} . \mathrm{oz}$; 20 cts. $\frac{1}{4}$ lb.; 60 cts. lb.

Pride of Georgia-Dark green, oval, a good shipper. If well-grown attains a large size. 10 cts. oz.; 25 cts $\frac{1}{4} \mathrm{lb}$; 70 cts. lb.

Seminole-It is of two distinct colors, gray and light green. Melons of both colors are of ten found on the same vine, and while of large size, it is very early, productive and of excellent quality 10 cts. oz.; 25 cts. $\frac{1}{4} \mathrm{lb}$.; $70 \mathrm{cts}$. lb.

True Dark Icing-Very solid, rind very thin, highly prized as a shipper. $10 \mathrm{cts}$. oz.; 20 cts. $\frac{1}{4} \mathrm{lb}$; 60 cts. lb.

Light Icing-Solid, always of good flavor, and thin light green rind. 10 cts. oz.; 20 cts. $\frac{1}{4}$ lb.; 60 cts. lb.

Citron-A round, handsome fruit of small size, used for making sweet meats and preserves, seeds red, flesh white. 10 cts. oz.; 25 cts. $\frac{1}{4}$ lb.; 70 cts. lb.

Sweetheart-Fruit large, oval, very heavy, uniformly mottled light and dark green, rind thin but firm, flesh bright red, firm, solid but very tender, melting and sweet. 10 cts. oz.; 20 cts. $\frac{1}{4}$ lb.; 60 cts. lb. 


\section{WATERMELON-Continued}

Tom Watson-A large long melon with dark green rind and light crimson flesh of excellent quality. It is a splendid shipper and is being grown extensively in the South for Northern markets. 10 cts. oz.; 25 cts. $\frac{1}{4}$ lb.; 75 cts. lb.

Alabama Sweet-A first-class shipper and market melon. Large, long, dark green with still darker stripes. The meat is bright red, solid and very sweet. $10^{\circ}$ cts. oz.; 25 cts. $\frac{1}{4} \mathrm{lb}$; 60 cts. $\mathrm{lb}$.

"Iceberg" or Blue Gem-The melons are uniformly large, of thick oval form, slightly depressed at the blossom end. The color is rich dark green with faint stripings of a lighter shade but the whole fruit is much darker and richer in coloring than the Kolb Gem. The rind is exceptionally strong, making it an excellent shipper. The flesh is entirely free from stringiness, and of sweet sugary flavor. 10 cts. oz.; 25 cts. $\frac{1}{4} \mathrm{lb}$.; 60 cts. lb.

Kleckley's Sweet ot Monte Cristo-A splendid sort for new markets. Vine vigorous and productive, fruit of medium size, oval, color dark, mottled green in two shades, forming indistinct stripes. Flesh very bright, rich red, exceedingly sweet and tender. 10 cts. oz.; 25 cts. $\frac{1}{4} \mathrm{lb}$; 75 cts. lb.

\section{MELON, MUSK (Zucker Melone, Ger.)}

A light rich soil is the most suitable for melons of all kinds. In very rich soil the hills should be six feet apart, in poor soil about five feet. Before planting the seed, mix about a peck of rotted manure with the soil in each hill. About the middle of May, plant the seeds half an inch deep, 6 or 8 in each hill. When the plants are well up, thin out, leaving 3 to a hill. One ounce of seed to 60 hills, 2 to 3 pounds for an acre.

Rocky Ford-This wonderful and delicious Melon has attracted more attention than ever before known in the history of the melon trade, and will soon be foremost in demand. It can not be excelled in flavor and is one of the best for shipping. No market gardener should be without it as it is sure to give satisfaction. As we only have a limited supply of this seed this season we would advise all to order early, so as not to be disappointed and thereby miss an opportunity of procuring a melon that recognizes no competition, but sells itself. It is round and of medium size, densely netted and thick meated. Will weigh on an average one to one and one-half pounds each, making it one of the most desirable of melons for restaurant and hotel purposes. 10 cts. oz.; 25 cts. $\frac{1}{4}$ lb.; 85 cts. lb.

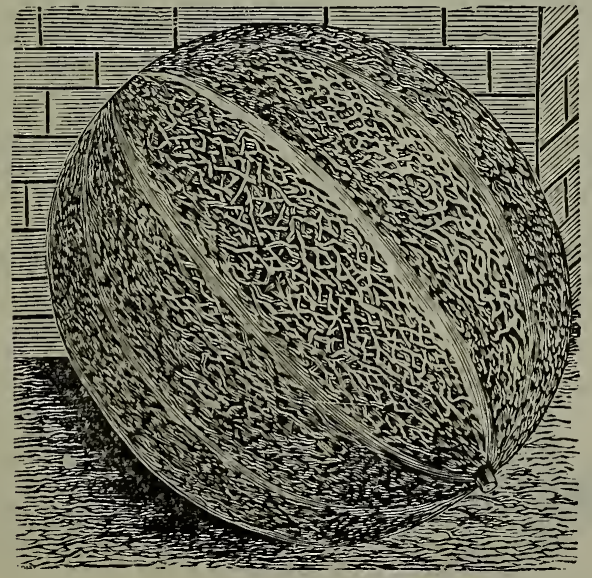

Tip Top-A yellow-fleshed melon of the very best qaulity. They are sweet, juicy, of finest flavor, eatable to the very rind. $10 \mathrm{cts}$. oz.; 25 cts. $\frac{1}{4} \mathrm{lb}$; $90 \mathrm{cts}$. lb.

Miller's Cream-A most delicious melon. The flesh is of a rich salmon color, very sweet and melting in quality and very thick. It is a strong grower and productive. 15 cts. oz.; 40 cts. $\frac{1}{4} \mathrm{lb}$.; $\$ 1.20 \mathrm{lb}$.
MELON MUSK-Continued

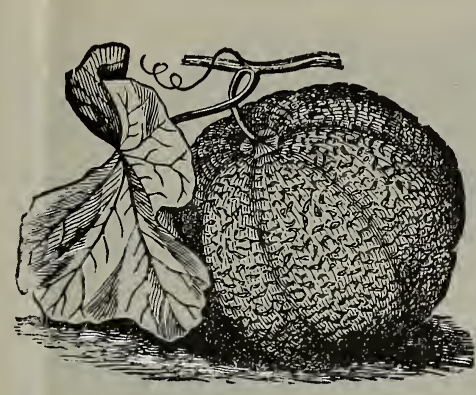

Skillman's Netted-An early sort, roundish-oval, flesh deep green, sweet, richly perfumed, delicious flavor. 10 cts. oz.; 25 cts. $\frac{1}{4}$ lb.; 75 cts. $1 \mathrm{~b}$. Green NutmegVery early, small, round, netted, green-fleshed sort, exceedingly sweet. 10 cts. oz.; 25 cts. $\frac{1}{4} \mathrm{lb} . ; 75$ cts. $\mathrm{lb}$.

Paul Rose-Cross between the Netted Gem and Miller's Cream, and combines in a remarkable degree the good qualities of both. The flesh is salmon colored, very deep and of fine melting character, with thin, tough rind, and small seed cavity. 10 cts. oz.; 25 cts. $\frac{1}{4}$ lb.; 85 cts. lb.

Burrell's Gem.-The originator says: "The new Rocky Ford Melon with Golden Meat." This described the melon fully, as in appearance it looks just as the best types of green fleshed Gems, or Rocky Fords do. $10 \mathrm{cts}$. oz.; 25 cts. $\frac{1}{4}$ lb.; 85 cts. lb.

Extra Early Hackensack-Fast becoming the most popular variety with market gardeners. Fruit large, round and netted. Flesh green and deliciously flavored. Very productive indeed and a good shipper. $10 \mathrm{cts}$. oz.; $25 \mathrm{cts}$. $\frac{1}{4}$ lb.; 90 cts. lb.

Emerald Gem-Of medium size, and a deep emerald green color. Flesh is a suffused salmon color, almost red; flavor is sweet and luscious: 15 cts. oz.; 35 cts. $\frac{1}{4} \mathrm{lb}$; $\$ 1.00 \mathrm{lb}$.

Acme-The gardener's favorite. Slightly oblong $\varepsilon$ nd netted. The flesh is light green and thick, and has a rich, sweet flavor. It is a distinct variety, and one of the best for marketing. 15 cts. oz.; 35 cts. $\frac{1}{4} \mathrm{lb}$.; $\$ 1.00 \mathrm{lb}$.

Large Hackensack-Early, round, netted, deeply ribbed, flesh green, very sweet and highly flavored. 10 cts. oz.; 25 cts. $\frac{1}{4} \mathrm{lb}$; 90 cts. lb.

Imrpoved Cantaloupe-Flesh light green, very prolific. 10 cts. oz.; 25 cts. $\frac{1}{4}$ lb.; 75 cts. lb.

Casaba or Large Persian-Green flesh, oblong form and large size. $10 \mathrm{cts}$. oz.; 25 cts. $\frac{1}{4}$ lb.; 75 cts. lb.

Netted Gem-Very early, small, coarsely netted, green flesh, fine flavored. 10 cts. oz.; 25 cts. $\frac{1}{4}$ lb.; 85 cts. lb.

\section{MUSTARD (Senf, Ger.)}

Sow thickly in drills, eight or ten inches apart, in rich, loamy soil, covering the seeds half an inch deep. When young, the leaves are used in salad, and in a more advanced stage, as greens, in the same way as spinach. Sowing may be made from April to July.

Southern Giant Curled-Is highly esteemed in the South where the seed is sown in the fall and plants used early in spring as a salad Seeds brown. Plants are 2 feet high; enormous bunches. 10 cts. oz.; 20 cts. $\frac{1}{4} \mathrm{lb}$.; 50 cts. lb.

White-The best for salads, the seeds are also used for mixing with pickles and for preserving cider. $10 \mathrm{cts}$. oz.; 15 cts. $\frac{1}{4}$ lb.; 30 cts. $1 \mathrm{~b}$.

Brown-The mustard of commerce, more pungent than the White for this purpose. 10 cts. oz.; 15 cts. $\frac{1}{4}$ lb.; 30 cts. lb.

\section{NASTURTIUM, (Nasturtium, Ger.)}

The young seed-pods are much esteemed for capers; making very delicate pickles. The plants are also highly ornamental, and are worthy of a place in the flower-garden for the sake of their brilliant flowers.

Tall Mixed-10 cts. oz.; 25 cts. $\frac{1}{4} \mathrm{lb}$; 75 cts. lb.

Dwarf Mixed-10 cts. oz.; 25 cts. $\frac{1}{4}$ lb.; 75 cts. lb. 


\section{MUSHROOM SPAWN.}

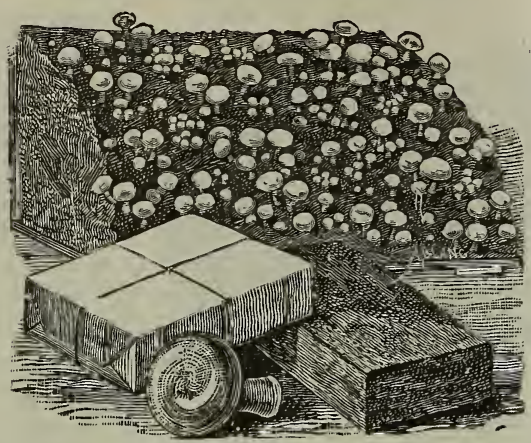

One pound will spawn about ten feet square.

In preparing a mushroom bed, take three parts fresh stable manure, free from straw, and one part of good pasture soil. Mix thoroughly together and let it stand until the heat has sunk to about 90 degrees. Make the bed from this mixture about four feet wide, eight inches deep, and any desired length. As soon as the temperature of the bed is about 70 or 80 degrees, the spawn may be inserted in pieces about the size of a walnut, and six inches apart each way. When the spawn is diffused through the whole bed, which will be in about ten days from planting, cover with two inches of fine loam and press down firmly. Over this place a layer of straw about four inches thick. Do not water unless the surface gets extremely dry, and then only with water at a temperature of 80 degrees. When gathering the crop, twist them off at the roots and do not use a knife. Cover the hole with soil to keep insects away from the root. Mushrooms can be grown in a great variety of situations; under the benches in a green house, a dark room, cellar, stable or elsewhere.

English Mill Track Spawn-(in bricks.) $15 \mathrm{cts.} \mathrm{1b.} \mathrm{(mail}$ 25 cts. lb.) $10 \mathrm{lbs} . \$ 1.00$.

Treatise on Mushroom Culture-10 cts. each postpaid.

\section{OKRA or GUMBO (Ocker, Ger.)}

The young, green seed-pods of this plant are used in soups, or stewed and served like asparagus. The young pods can also be dried for winter use.

Improved Dwarf Green-This variety has long, slender pods, very early, productive, and only grows 14 inches high. 10 cts. oz.; 20 cts. $\frac{1}{4}$ lb.; 60 cts. lb.

White Velvet-The pods of this variety are round and smooth, and much larger than the common varieties, and are produced in great abundance. 10 cts. oz.; 20 cts. $\frac{1}{4}$ lb.; 60 cts. lb.

\section{ONION (Zwiebeln, Ger.)}

A light, loamy soil suits the onion best, and it may be grown for many consecutive years on the same ground. Previous to sowing, the ground should be well manured and deeply plowed. Harrow and rake the surface smooth and even As early in spring as possible, sow the seed in drills 14 inches apart and half an inch deep, rolling firmly over the seed. A cultivator may be used between the drills, being careful not to throw too much over the crop. Weed the drills very carefully and never allow the weeds to get ahead of the young plants. One ounce to 100 feet of drill, 4 to 5 pounds per acre.

Extra Early Red-A very early variety, of medium size, deep red, mild flavor, largely grown for sets. 15 cts. oz.; 40 cts. $\frac{1}{4} \mathrm{lb}$.

Large Red Wethersfield-Excellent flavor, grows large, hardy and keeps well. 15 cts. oz.; 40 cts. $\frac{1}{4} \mathrm{lb}$.; $\$ 1.25 \mathrm{lb}$.

Danver's Yellow Globe-Early, with very small neck, large size, fine quality and good keeper, the best for general crop. 15 cts. oz.; 40 cts. $\frac{1}{4} \mathrm{lb}$; $\$ 1.25 \mathrm{lb}$.

\section{ONION-Continued}

Large Yellow Dutch-Favorite old variety, large, round and excellent keeper. $10 \mathrm{cts}$. oz.; $35 \mathrm{cts} . \frac{1}{4} \mathrm{lb}$.; $\$ 1.20 \mathrm{lb}$.

Prize Taker-The skin is a bright straw color, flesh white, very thick and of mild flavor. It is to-day one of the largest, handsomest and most profitable variety grown. 15 cts. oz.; 40 cts. $\frac{1}{4} \mathrm{lb}$.

White Portugal or Silver Skin-Early, mild flavored and excellent for first crop. 20 cts. oz.; 60 cts. $\frac{1}{4} \mathrm{lb}$.

White Globe-This variety yields abundantly, produces handsome, globe-shaped bulbs, the flesh is firm, fine grained of mild flavor. 20 cts. oz.; 60 cts. $\frac{1}{4} \mathrm{lb}$.

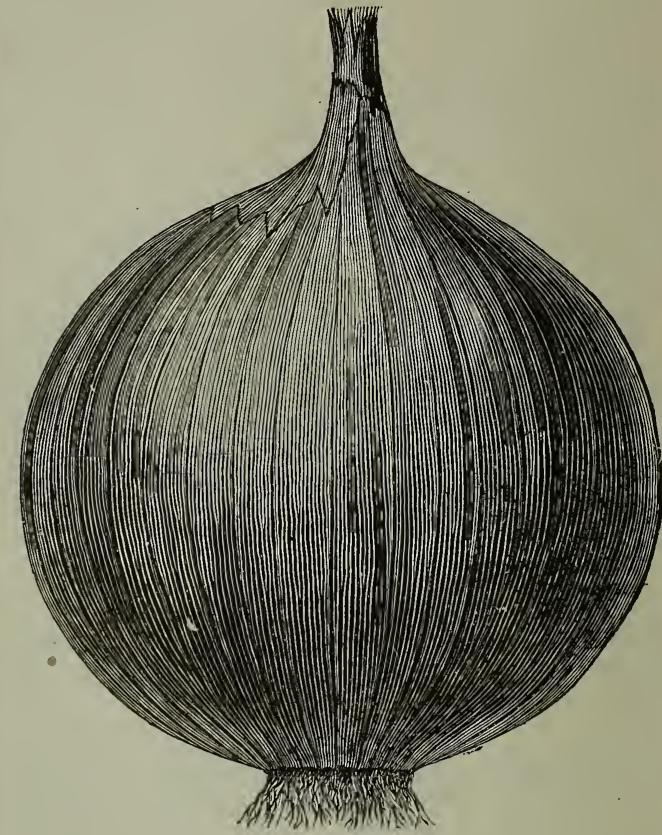

Ohio Yellow Globe-The finest shaped, best colored and largest cropper of any of the yellow onions, and entirely distinct from the old type Yellow Globe Danvers. $15 \mathrm{cts}$. oz.; 40 cts. $\frac{1}{4} \mathrm{lb}$; $\$ 1.35 \mathrm{lb}$.

Australian Brown-Is of medium size, wonderfully hard and solid, and most attractive for markets, both as to form and appearance. They are extremely early and never make any stiff necks or scallions. The color of the skin is a clear amber brown, in marked contrast to that of all other onions. 15 cts. oz.; 40 cts. $\frac{1}{4} \mathrm{lb}$.; $\$ 1.25 \mathrm{lb}$.

White Barletta-An extra early small, white Onion; similar to White Queen, 20 cts. oz.; 60 cts. $\frac{1}{4} \mathrm{lb}$.

Early Flat Yellow Danvers. Different from the Globe strain only in shape, being more flat. A splendid Onion for the market or home use; sells readily in the market. Very productive. 15 cts. oz.; 40 cts. $\frac{1}{4} \mathrm{lb}$.; $\$ 1.25 \mathrm{lb}$.

\section{ONION SETS.}

Add 5 cents per pint and 10 cents per quart for Postage.

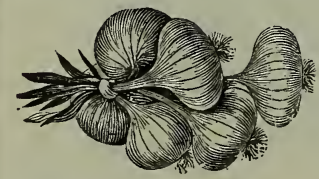

Yellow Bottom Sets......

Red Bottom Sets..........

White Bottom Sets.......

Top Sets.

Potato Sets

White Multiplier Sets
These are valuable for early use and where onions from seed can not be raised the first year. Plant near the surface in drills 12 inches apart and 4 inches in the rows.

20 cts. qt. Price per peck and bushel on application. 


\section{PARSLEY (Petersilie, Ger.)}

Parsley succeeds best in a rich, mellow soil. As the seeds germinate very slowly, three or four weeks elapsing sometimes before it makes its appearance, it should be sown early in spring. Sow thickly in rows a foot apart and half an inch deep. For winter use, protect in a frame or light cellar. One ounce will sow 150 feet of drill.

Double Curled-A fine dwarf variety, beautifully curled, excellent for garnishing. $15 \mathrm{cts}$. oz.; $35 \mathrm{cts}$. $\frac{1}{4} \mathrm{lb}$.; $\$ 1.00 \mathrm{lb}$.

Champion Moss Curled-A very select stock, beautifully crimped and curled. 15 cts. oz.; 35 cts. $\frac{1}{4} \mathrm{lb}$; $\$ 1.00 \mathrm{lb}$.

Plain Leaved-Very strong flavor. $10 \mathrm{cts}$. oz.; $35 \mathrm{cts}$. $\frac{1}{4} \mathrm{lb} . ; \$ 1.00 \mathrm{lb}$.

Hamburg or Turnip Rooted-The roots of this variety are used largely for flavoring purposes; resemble small parsnips. Flesh white and of fine flavor. $15 \mathrm{cts} . \mathrm{oz}$.; $30 \mathrm{cts}$. $\frac{1}{4} \mathrm{lb} . ; 90$ cts. $\mathrm{lb}$.

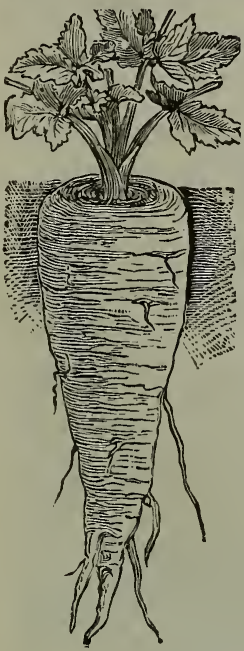

\section{PARSNIP (Pastinake, Ger.)}

Sow as early in the spring as the weather will admit, in drills 15 inches apart in the rows. Unlike carrots, they are improved by frost, and it is usual to take up in fall a certain quantity for winter use, leaving the rest in the ground until spring, to be dug up as required. One ounce will sow 200 feet of drill, five pounds to an acre

Long Sugar-The best for general use 10 cts. oz.; 20 cts. $\frac{1}{4}$ lb.; 60 cts. lb.

Hollow Crown-Good old sort. 10 cts. $\mathrm{oz}$.; 20 cts. $\frac{1}{4} \mathrm{lb}$; 60 cts. $1 \mathrm{~b}$.

\section{PEAS (Erbsen, Ger.)}

Peas come earlier to maturity in light, rich soil. For general crop a good dressing should be applied, and for the dwarf-growing kinds the soil can hardly be too rich. Plant the early varieties as soon as the ground can be worked, the others in succession from April to June. For private use they are generally sown in double or single rows, in drills, about two feet apart and three inches deep, for the dwarf varieties, three to four feet apart, and four inches deep for the taller varieties. Those growing over two and a half feet in height should be bushed. One quart to 80 feet of drill, $1 \frac{1}{2}$ bushel for one acre.

Add 10 cts. per pint, 15 cts per quart extra, if sent by mail. Wrinkled Varieties Marked *.

J. C. McC's Extra Early (Pedigree Stock)-Being grown in the far North snd with the selection of the earliest and choicest vines, this strain has been so improved that it fully bears out our claim as the earliest, most prolific and even strain in existence, maturing so well together that sometimes a single picking will secure the entire crop. Vines, vigorous and hardy, 2 to $2 \frac{1}{2}$ feet high, bearing abundantly. Market gardeners, who can not afford to go over the rows several times for small quantities of pods, will do well to give this strain a trial. 15 cts. pt.; $25 \mathrm{cts}$. qt.

*Gradus (Prosperity)-Extra early, very large pods. Table quality quite equal to Telephone. It is very hardy and can be planted as early as the smooth peas, bears heavy crops; the large peas retain their rich color after cooking and are deliciously sweet. Well worth a trial. 20 cts. pt.; 40 cts. qt.

*Sutton's Excelsior-An extra early Pea, producing large pods, well filled with peas of delicious flavor. $1 \frac{1}{2} \mathrm{ft} .15$ cts. pt.; 25 cts. qt.
PEAS-Continued.

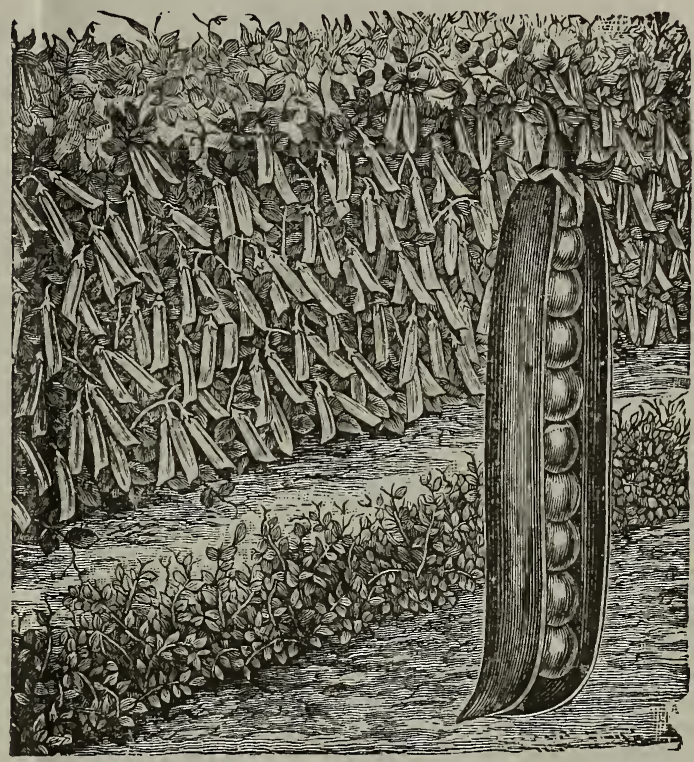

First and Best-Our selected stock of this fine, standard variety is quite unsurpassed for earliness, productiveness, excellent flavor and size of pod, two feet high. $15 \mathrm{cts}$. pt.; 25 cts. qt.

Alaska-One of the earliest and most productive of the very early peas, distinct, two feet. 15 cts. pt.; 25 cts. qt. Maud S-Have a limited supply from original stock. 15 cts. pt.; 25 cts. qt.

Philadelphia Extra Early-The well-known early variety, height two and a half feet. 15 cts. pt.; 25 cts. qt.

Improved Daniel O'Rourke-Very early, fine cropper, long pods, exquisite flavor, height two and a half feet. 15 cts. pt.; 25 cts. qt.

Early Kent or May-A favorite first early variety. 15 cts. pt.; 25 cts. qt.

Tom Thumb-An old and well-known dwarf sort, height ten inches. 15 cts. pt.; 25 cts. qt.

*Little Marvel-A first early green wrinkled marrow, 18 inches high and of robust and vigorous growth. It is an enormous cropper, bearing good sized pods well filled with exceedingly sweet and luscious peas. $15 \mathrm{cts}$. pt.; $25 \mathrm{cts}$. qt.

*American Wonder-A remarkably fine, dwarf wrinkled variety, extra early, requires no bushing, very sweet flavor, height about one foot. 15 cts. pt.; 25 cts. qt.

*McLean's Litt̂le Gem-An early green marrow of excellent quality and an abundant bearer, height one and one-half foot. 15 cts. pt.; 25 cts. qt.

*Advancer-A finely flavored green wrinkled marrow, very productive and uniform, we can not recommend this sort too highly, height two and a qaurter feet. $15 \mathrm{cts}$. pt.; 25 cts. qt.

*Improved Champion of England-One of the best peas grown, unsurpassed in flavor, sweetness and general excellence. Our stock is maintained pure by careful selection, height five feet. 15 cts. pt.; 25 cts. qt.

*Stratagem-The best late marrow pea grown, immense pods, splendid flavor, vigorous growth, very popular, height two and a half feet. 15 cts. pt.; 30 cts. qt.

*Carter's Telephone-Green wrinkled, peculiar light shade of green, productive pods unusually large size, elegant shape, slightly curved, well filled with peas, large size, good quality, height three and a half feet. 15 cts. pt.; 25 cts.

qt. Alderman-Vines grow about $5 \mathrm{ft}$. high. Peas of large size, unsurpassed in quality, 15 cts. pt.; 30 cts. qt. 


\section{PEAS-Continued}

Telegraph or Long Island Mammoth-A good main crop variety, producing strong growing vines with very large dark green pods. 15 cts. pt.; 25 cts. qt.

Black Eye Marrow-A good late sort for market, hardy, productive, excellent either as a field or table pea, height three feet. 15 cts. pt.; 25 cts. qt.

Large White Marrow-One of the best late sorts, very productive, good flavor, height five feet. 15 cts. pt.; 25 cts. qt.

*Bliss' Everbearing-Height, 18 inches, a continuous bearing wrinkled variety. The best for late planting. 15 cts. pt.; 25 cts. qt.

*Carter's Daisy or Dwarf Telephone-It grows about 18 inches high and is remarkable for its abundance of large, well-filled pods. It is a dwarf early form of the popular Telephone. It is of healthy, stocky growth, and requires no brush. 20 cts. pt.; 35 cts. qt.

*Nott's Excelsior-Remarkably hardy and productive one of the eraliest of wrinkled peas. It is unsurpassed in size and qaulity. 15 cts. pt.; 25 cts. qt.

*Thomas Laxton-The introducers of this variety claim that in point of earliness, size of pod and table quality it excels any sort now in used. 20 cts. pt.; 40 cts. qt.

*Carter's Premium Gem-An improved Little Gem. Dwarf, prolific, fine flavored, large pods, excellent, either for market or home use, height one and one-half feet. 15 cts. pt.; 25 cts. qt.

Petit Pois or French Canners-Vines grow 3 to 4 feet in height. The long, slim pods contain 8 to 10 .small peas of tender delicate quality; vines vigorous; medium early and prolific. 15 cts. pt.; 25 cts. qt.

Melting Sugar-An edible podded variety growing from four to five feet high; pods very large, four to five inches long, and one or more broad, each usually containing from five to eight large peas. Being edible podded, it should be used the same way as a wax bean; very sweet and tender. 20 cts. pt.; 35 cts. qt.

Pride of the Market.-A strong growing variety, growing from 18 to 23 inches high, and is very productive. The pods are unusally large and the peas, when cooked, are of very superior quality. $15 \mathrm{cts}$. pt.; 25 cts. qt.

Canada Field-Mostly used as a field crop. 10 cts. lb.; 65 cts. pk. Subject to market change.

\section{PEPPER (Pfeffer, Ger.)}

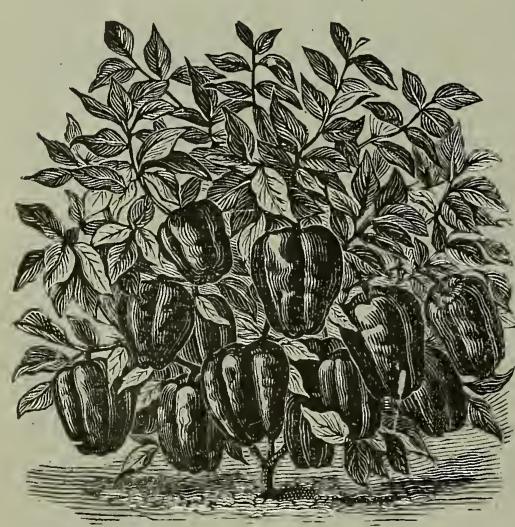

A light, warm loam is the best soil for peppers. Sow in March or A'pril, in a hot-bed, and transplant when the weather is warm. They are quite tender, and will not bear frost. Set the plants fifteen inches apart and two f e et between therows. One ounce for 1,500 plants.

Golden Dawn-A new variety, very handsome, golden yellow, sweet, mild, and very productive. 20 cts. oz.; 60 cts. $\frac{1}{4} \mathrm{lb}$; $\$ 2.00 \mathrm{lb}$.

Chinese Giant-Double the size of Ruby King. Flesh very mild and thick. Excellent sliced for salad. 35 cts. oz.; $\$ 1.00 \frac{1}{4} \mathrm{lb}$.

Red Chili-Small, cone-shaped, bright red, fiery. 25 cts. $0 \%$. 75 cts. $\frac{1}{4} \mathrm{lb}$.

\section{PEPPER--Continued}

Large Bell or Bull Nose-Large, early bright red, mild. 20 cts. oz.; 60 cts. $\frac{1}{4}$ lb.; $\$ 2.00$ lb.

Sweet Mountain-A large early sort, mild and excellent bright red. 25 cts. oz.; 75 cts. $\frac{1}{4} \mathrm{lb}$.

Long Red Cayenne-Long bright red, fiery. 20 cts. oz.; 60 cts. $\frac{1}{4}$ lb.; $\$ 2.00 \mathrm{lb}$.

Ruby King-Beautiful, bright red, large fruit and mild, the best pepper for mangoes in cultivation. $25 \mathrm{cts}$. oz.; 75 cts. $\frac{1}{4} \mathrm{lb}$; $\$ 2.25 \mathrm{lb}$.

\section{PUMPKIN (KUERBIS, Ger.)}

These are usually grown for stock feed, and are generally scattered at intervals in the hills while planting sweet corn. For making pumpkin pies the squashes are very much superior. One ounce to fifteen hills, 3 to 4 pounds to an acre.

Large Cheese-Very superior, productive, fine grained. good flavor, cheese shaped. 10 cts. oz.; 20 cts. $\frac{1}{4}$ lb.; 50 cts. lb.

Cashaw-One of the largest and best, yellow solid, good keeper. 10 cts. oz.; 25 cts. $\frac{1}{4}$ lb.; 75 cts. lb.

Large Tours-Grows enormously large, round, flattened, skin salmon, flesh yellow, fine grained, good quality. 15 cts. oz.; 35 cts. $\frac{1}{4} \mathrm{lb}$.

Tennessee Sweet Potato-An excellent variety for pies, pear shaped, of medium size, flesh and skin creamy white, fine grained, very sweet and delicious. $10 \mathrm{cts}$. oz.; $25 \mathrm{cts}$. $\frac{1}{4}$ lb.; 75 cts. lb.

Kentucky Field-Good for cooking purposes or for feeding stock. 10 cts. oz.; 20 cts. $\frac{1}{4}$ lb.; 40 cts. lb.

Connecticut Field-The common yellow pumpkin. 10 cts. oz.; 20 cts. $\frac{1}{4}$ lb.; 40 cts. lb.

Mammoth-This is the Big Show Pumpkin, catalouged under the various aliases, "King of the Mammoths," "Jumbo," "True Potiron," "\$50 Prize," etc. Specimens have weighed over 200 pounds. Skin salmon color; flesh, bright yellow. Keeps a long time. 15 cts. oz.; 35 cts. $\frac{1}{4}$ lb.; $\$ 1.25 \mathrm{lb}$.

Japanese Pie-Crooked necked, very productive, ripens early, of medium size. Excellent for pies. 10 cts. oz.; 25 cts. $\frac{1}{4} \mathrm{lb}$.; 75 cts. $\mathrm{lb}$.

\section{RADISH (Radies, Ger.)}

All the varieties thrive best in a light, sandy loam. For early use sow in the hot-bed in February, giving plenty of ventilation, or outside in drills as soon as the soil can be got in order, covering the seed about half an inch deep. Sow every two weeks, from March to September, for a succession, they must grow rapidly to be crisp, mild and tender. One ounce sows 100 feet of drill, 8 to 10 pounds to an acre.

Cincinnati MarketGrows six to seven inches in length, straight and smooth, flesh is exceedingly tender, crisp and delicious; never becomes hollow and pithy.

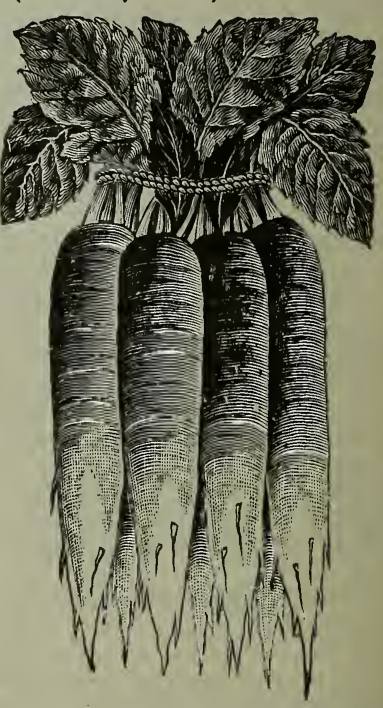

Skin is very thin and has an attractive, glossy appearance. Undoubtedly the finest long red Radish for either the market or house gardener. 10 cts. oz.; 25 cts. $\frac{1}{4}$ lb.; 70 cts. lb.

PREMIUM. To every one who purchases SEEDS to the value of $25 \mathrm{c}$ or more we will present a large package of mixed Annual Flower Seeds, 100 varieties or more. 


\section{RADISH-Continued}

White Icicle-The roots of this radish grow about 4 inches long are of transparent whiteness, with short leaves, and make their growth very quickly. It is of most excellent flavor and equally desirable for home use and market gardeners. 10 cts. oz.; 25 cts. $\frac{1}{4} \mathrm{lb}$.; $75 \mathrm{cts}$. lb.

Early Scarlet Turnip-The standard early, short, quickgrowing variety. 10 cts. oz.; 20 cts. $\frac{1}{4}$ lb.; 50 cts. lb.

Early White Turnip-Of mild flavor, excellent for summer use. 10 cts. oz.; 20 cts. 1 lb.; 50 cts. lb.

Early Long Scarlet Short Top-The standard variety for market and private use. 10 cts. oz.; 20 cts. $\frac{1}{4} \mathrm{lb}$.; $50 \mathrm{cts}$. $\mathrm{lb}$.

French Breakfast-Form oval, scarlet, tipped with white, quick growing, and excellent flavor. 10 cts. oz.; 20 cts. $\frac{1}{4} \mathrm{lb}$.; 50 cts. lb.

Golden Globe-This variety is very popular. It is of a quick growth, tender and brittle, of perfect globe shape. 10 cts. oz.; 25 cts. $\frac{1}{4} \mathrm{lb}$.; 60 cts. lb.

Giant White Stuttgart-A quick-growing early sort, largest size, flesh and skin pure white, fine quality; firm and brittle, never gets pithy. $10 \mathrm{cts} .0 \mathrm{z} .20 \mathrm{cts} . \frac{1}{4} \mathrm{lb}$.; $50 \mathrm{cts} . \mathrm{lb}$.

White Strasburg-A large, handsome white variety, of excellent quality; early. $10 \mathrm{cts}$. oz.; $20 \mathrm{cts} . \frac{1}{4} \mathrm{lb}$.; $60 \mathrm{cts}$. $\mathrm{lb}$

Long White Naples-A handsome, long, clean, white radish, crisp and tender, good for summer use. 10 cts. oz.; 20 cts. $\frac{1}{4} \mathrm{lb}$; 60 cts. lb.

Brighest Long Scarlet-It is very early, maturing in 20 to 25 days, the flesh crisp and tender, excellent for home garden and particularly desirable for the market, as it sells quickly beeause of its fine color and form. $10 \mathrm{cts}$. oz.; 20 cts. $\frac{1}{4}$ lb.; 50 cts. lb.

Wood's Early Frame-Long scarlet radish, excellent for forcing. $10 \mathrm{cts}$. oz.; 20 cts. $\frac{1}{4}$ lb.; 60 cts. lb.

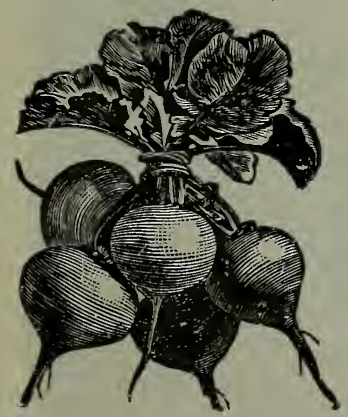

Golden Dresden-We recommend it alike for family garden and for market as one of the most valuable and quick growing radishes. Tops very scant and admit of close planting. It is perfectly round, smooth and very attractive, light golden brown skin. The flesh is crisp, white, juicy and of finest flavor. Market gardeners can grow this new radish in the garden or force it, and depend upon a remarkable perfect, early, uniform crop. 10 cts. oz.; 25 cts. $\frac{1}{4}$ lb.; 75 cts. lb.

Chinese Rose Winter-Popular winter sort, medium size, bright rose, excellent. $10 \mathrm{coz}$; $20 \mathrm{cts} . \frac{1}{4} \mathrm{lb}$.; $60 \mathrm{cts}$. lb.

Round Black Spanish-A winter variety, large, mild and firm, skin black, flesh white. 10 cts. oz.; 20 cts. $\frac{1}{4}$ lb.; 60 cts. lb.

Long Black Spanish-Same as above, except in shape. 10 cts. oz.; 20 cts. $\frac{1}{4} \mathrm{lb}$.; 60 cts. lb.

Celestial-This is the finest of fall Winter radishes. Very large; paper white skin; flesh solid, crisp and sweet as a turnip. 10 cts. oz.; 25 cts. $\frac{1}{4} \mathrm{lb}$.; 75 cts. lb.

California Mammoth White-Grow extensively by Chinese in California, 8 to 12 inches long, 2 to 3 inches in diameter, white, solid, good flavor. $10 \mathrm{cts}$. oz.; $20 \mathrm{cts} . \frac{1}{4}$ lb.; 60 ets. lb.

Radish Mixture, all sorts-This is especially adapted to the wants of those having only a small garden, as it contains all of the leading varieties, and will give a succession of fine radishes. Try a package. It will please you. 10 cts. oz.; 20 cts. $\frac{1}{4}$ lb.; 50 cts. lb.

\section{RHUBARB (Rhabarber, Ger.)}

A deep, rich soil is the best for rhubarb; sow early in drills 18 inches apart and 1 inch deep; the spring following transplant; allowing each plant at least 2 feet square. One ounce for about 800 plants.
Linnaeus-Extra large, tender. 15 cts. oz.; 50 cts. $\frac{1}{4} \mathrm{lb}$; $\$ 1.50 \mathrm{lb}$.

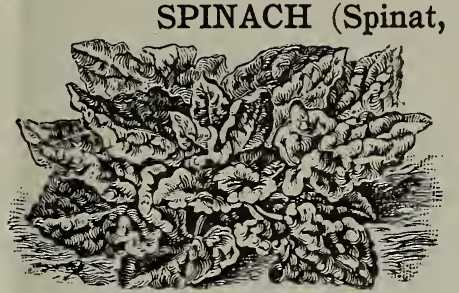

This is the best developed a $\mathrm{n} d$ most tender and succulent when grown in very rich soil. For summer use sow early in spring in drills 15 inches apart, and make sowing every two weeks. For spring use sow in September, and cover lightly in November with light litter. One ounce to 100 feet of drill. Ten to twelve pounds per acre.

Bloomsdale Savoy-Thick, succulent leaves, very productive and hardy. 15 cts. $\frac{1}{4} \mathrm{lb}$.; 35 cts. $1 \mathrm{~b}$.

Round Thick Leaf-One of the best for early spring or fall sowing, leaves large, thick and succulent. 15 cts. $\frac{1}{4}$ lb.; 35 cts. lb.

Long Standing Thick Leaved-Does not run to seed so readily as the other. $15 \mathrm{cts} . \frac{1}{4} \mathrm{lb}$; $35 \mathrm{cts} . \mathrm{lb}$.

New Zealand (Tetragonia expansa)-Unlike true spinach in type and in that it thrives during hot weather and in any soil, rich or poor. The tender shoots are of good quality and may be cut throughout the summer. The plant becomes very large and spreading; leaves small, broad but pointed. Plant three or four seeds in hills two feet apart each way. $10 \mathrm{cts}$. oz.; 25 cts. $\frac{1}{4} \mathrm{lb}$.; $60 \mathrm{cts}$. lb.

Prickly-Vigorous and hardy, good for winter. $15 \mathrm{cts}$. $\frac{1}{4} \mathrm{lb} . ; 35$ cts. lb.

\section{Special Prices given on Spinach in quantity.}

\section{SALSIFY (Hafer-wurzel, Ger.)}

Commonly called Vegetable Oyster. Used stewed, boiled or fried. When cooked has an oyster flavor. Sow early in drills 15 inches apart, cover the seed with fine soil, an inch and a half deep. One ounce will sow 50 feet, seven pounds to an acre.

Long White French-The standard variety. $10 \mathrm{cts} .0 z$; 25 cts. $\frac{1}{4}$ lb.; 90 cts. lb.

Mammoth Sandwich Island-This variety is of enormous size, twice as large as the ordinary sort, very tender and delicious. 15 cts. oz.; 35 cts. $\frac{1}{4}$ lb.; $\$ 1.25 \mathrm{lb}$.

\section{SQUASH (Kuerbis, Ger.)}

The squash is of tropical origin, and only succeeds well in a warm temperature, consequently the seeds should not be planted out until the ground is warm and mellow. The hills should be about six feet apart for winter varieties, and four feet for summer sorts. Plant a dozen seeds in each hill. Thin out the weakest vines, and when all danger from bugs is past, leave three vigorous vines to the hill. Cultivate well, and keep the ground clear of weeds. One ounce of seed to about 40 hills, four to six pounds to the acre.

Early White Bush or Patty Pan-A scolloped sort, best for early use. $10 \mathrm{cts}$. oz.; $25 \mathrm{cts} . \frac{1}{4} \mathrm{lb}$; 80 cts. lb.

Summer Crook-Neck-The old standard sort; very early and productive. $10 \mathrm{cts}$. oz.; 25 cts. $\frac{1}{4} \mathrm{lb}$.; $80 \mathrm{cts}$. lb.

Mammoth Chili-Oblong, productive; profitable for stock feeding. 15 cts. oz.; 45 cts. $\frac{1}{4} \mathrm{lb}$.; $\$ 1.25 \mathrm{lb}$.

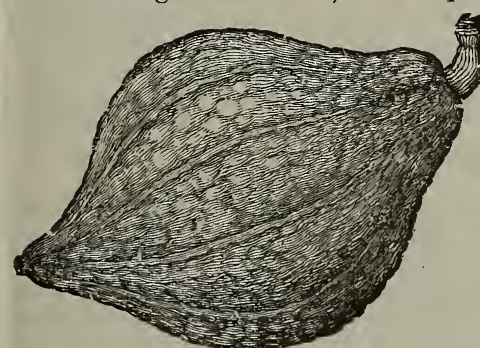

American Turban-Excellent quality, fles h thick and sweet, superior fall sort. 10 cts. oz.; 25 cts. $\frac{1}{4} \mathrm{lb}$; 80 cts. lb.

True Hubbard -A g e n eral favorite, hard, dark green shell, meat thick, dry and finely flavored. 10 cts. oz.; 25 cts. $\frac{1}{4}$ lb.; 80 cts. lb. 


\section{SQUASH-Continued}

Boston Marrow-Good keeper and of excellent flavor, shell orange, quite hard, several weeks earlier than the Hubbard. 10 cts. oz.; 25 cts. $\frac{1}{4}$ lb.; 80 cts. lb.

Warted Hubbard-A choice dark green and very warty selection from the well-known Hubbard, retaining all the good qualities of its parent Very handsome, a grand keeper, and sells at sight. 10 cts. oz.; 25 cts. $\frac{1}{4}$ lb.; 80 cts. lb.

Golden Hubbard-An exceptionally attractive variety of the true Hubbard type. At maturity the color is red, and the flesh bright orange. The vine is productive and the fruit is fit for use earlier than the Hubbard. 10 cts. oz.; 25 cts. $\frac{1}{4}$ lb.; 75 cts. lb.

Vegetable Marrow-A favorite English sort. The fruit is from nine to eighteen inches in length, and four to six inches in diameter. Skin a greenish yellow; flesh, white, soft and of rich flavor. Plant 8 feet apart. 10 cts. oz.; 25 cts. $\frac{1}{4} \mathrm{lb}$; 75 cts. $\mathrm{lb}$.

\section{TOMATO (Liebesapfel, Ger.)}

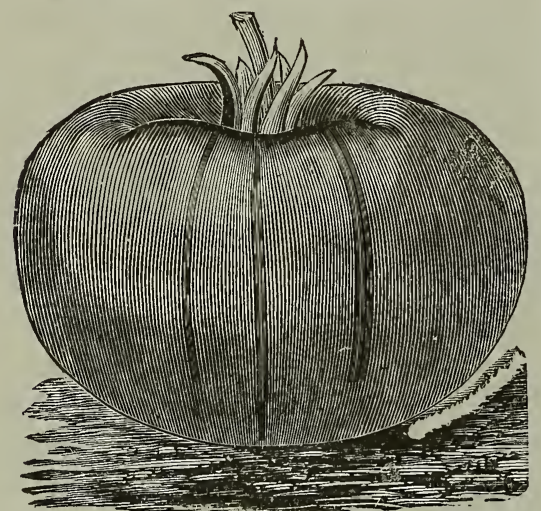

To obtain fruit very early, sow in the hot-bed in March. In about 5 weeks plants should be transplanted to another hot-bed, setting them 4 or 5 inches apart. Here they should remain, having all the air possible, until about the middle of May, when they may be put out in the ground. If not too early or too cold, a cold frame will answer for the first transplanting. Pinching off a portion of the side branches, and stopping others just beyond where the fruit is formed, hastens the ripening. Very good plants can be grown in boxes in the house. One ounce of seed will produce about 1500 plants.

Coreless-A late Red Tomato and the most perfect shaped variety yet produced. When bearing, the variety is immensely productive, yielding large clusters of four to seven fruits. A fine late sort for markets that like a red tomato, for the home garden and canners. 25 cts. oz.; 75 cts. $\frac{1}{4} \mathrm{lb}$.

June Pink-Similar in habit and shape to the famous Earliana, differs only in color which is pink instead of red. A most desirable sort where pink tomatoes are in favor. 25 cts. oz.; 75 cts: $\frac{1}{4} \mathrm{lb}$.

Buckeye State-The tomatoes are borne in immense clusters of four to eight fruits, and occasionally ten large fruits have been found on a single cluster. In solidity and meatiness it has no equal, while in luscious qualities none surpass it. The color is much the same as Beauty, but a darker and richer shade, and this, together with its very large size and clear-cut outlines, makes it very showy and striking when displayed for sale. $25 \mathrm{cts}$. oz.; $70 \mathrm{cts} . \frac{1}{4} \mathrm{lb}$; $\$ 2.50 \mathrm{lb}$.

Ponderosa-This monster tomato is all solid meat, being uniformly large, smooth, of dark rich crimson color, and a delicious sub-acid flavor. 25 cts. oz.; 90 cts. $\frac{1}{4} \mathrm{lb}$.

Earliana-An early sort of merit, said to be the earliest of all tomatoes; it is of uniform size and brilliant red color, of good quality. $25 \mathrm{cts}$. oz.; 70 cts. $\frac{1}{4} \mathrm{lb}$.

\section{TOMATO-Continued}

Stone-An excellent shipping variety, quality the very best, fine for canning, fruit large, very smooth, and of bright scarlet color, flesh firm and solid. 20 cts. oz.; 60 cts. $\frac{1}{4} \mathrm{lb}$; $\$ 2.00 \mathrm{lb}$.

Chalk's Early Jewel-A vey fine sort, growing large, solid and smooth, color is of bright red similar to the Stone. It is very early, a little behind the Earliana, but producing about three times as much fruit and the most uniform and smoothest grown; good market variety. 25 cts. oz.; 70 cts. $\frac{1}{4} \mathrm{lb}$.

Dwarf Stone-Double the size of the Dwarf Champion and is the largest fruited upright growing variety. The color is deep red of a perfect thick, smooth shape, a good skin which is free from cracks at stem end, very solid, ripens evenly and of excellent quality. $25 \mathrm{cts}$. oz.; $70 \mathrm{cts}$. $\frac{1}{4} \mathrm{lb}$.

Queen City-The best tomato for market, remarkably prolific; flesh thick and solid. This we consider our finest large fruited purple sort. The plants are of strong growth and most productive. The tomatoes are of large size, deep through, very smooth and regular, free from cracks, solidly meaty with small seed cells and of exceptionally fine flavor. 25 cts. oz.; 75 cts. $\frac{1}{4} \mathrm{lb}$.

Livingston's Beauty-Color very glossy. crimson, grows in clusters of four or five fruits, large and solid. $25 \mathrm{cts}$. oz.; 60 cts. $\frac{1}{4}$ lb.; $\$ 2.00 \mathrm{lb}$.

Dwarf Champion-This fine sort is quite distinct and very realy. The foliage is dark and the stem stiff, so that the plants stand up well, even when loaded with fruit The fruit is smooth, solid and excellent. $25 \mathrm{cts}$. oz.; 75 cts. $\frac{1}{4} \mathrm{lb}$.

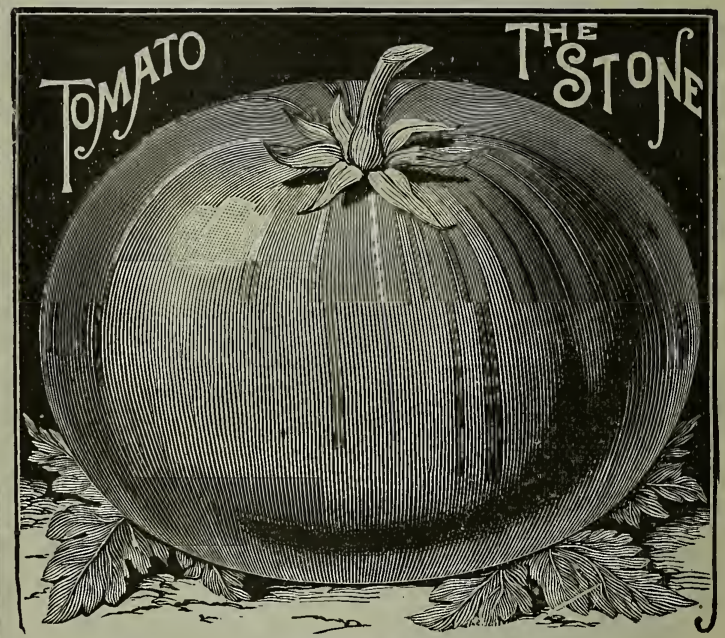

Golden Queen-The best yellow, medium early, smooth, round, very productive, excellent quality. 20 cts. oz.; 60 cts. $\frac{1}{4} \mathrm{lb}$; $\$ 2.00 \mathrm{lb}$.

Trucker's Favorite-It begins to ripen quite early and continues to bear profusely until frost; nothing exceeds it in productiveness; the fruit is large, solid, and smooth, beautiful reddish purple; presents a remarkably fine appearance; a good shipper. In fact, it will be found one of the most profitable tomatoes for main crop for the market gardener. 25 cts. oz.; 75 cts. $\frac{1}{4} \mathrm{lb}$.

Livingston's Favorite-Productive, good flavor, few seeds, flesh solid, smooth and handsome. 25 cts. oz.; 60 cts. $\frac{1}{4}$ lb.; $\$ 2.00 \mathrm{lb}$.

Livingston's Perfection-Early, large, smooth and solid, blood red color. 20 cts. oz.; 60 cts. $\frac{1}{4}$ lb.; $\$ 2.00 \mathrm{lb}$.

Early Acme-One of the earliest. The fruit is of medium size, perfectly smooth and regular in shape, color quite distinct, being a dark red, with a purplish tinge. 25 cts. oz.; 60 cts. $\frac{1}{4}$ lb.; $\$ 2.00$ lb.

Trophy-Fruit very large, solid and heavy, excellent for main crop. 25 cts. oz.; 60 cts. $\frac{1}{4}$ lb.; $\$ 2.00 \mathrm{lb}$. 


\section{TOMATO-Continued}

Cincinnati Purple-A valuable variety, especially adapted for canning and shipping. It is very large, color a dark purplish red, very productive and of rich flavor. $25 \mathrm{cts}$. oz.; 60 cts. $\frac{1}{4}$ lb.; $\$ 2.00 \mathrm{lb}$.

Matchless-A large, bright red tomato, which has become very popular in the East. The fruit is large, very smooth and symmetrical, ripening well to stem. $20 \mathrm{cts}$. oz.; 60 cts. $\frac{1}{4}$ lb.; $\$ 2.00 \mathrm{lb}$.

Yellow Pear Shape-Fine for preserves or pickling. 25 cts. oz.; 75 cts. $\frac{1}{4} \mathrm{lb}$.; $\$ 2.50 \mathrm{lb}$.

Cherry, Red and Yellow-For preserves and pickling. 25 cts. oz.; 75 cts. $\frac{1}{4}$ lb.; $\$ 2.50$ lb.

\section{TOBACCO (Taback, Ger.)}

The seed should be sown as early as possible after the danger of frost is over. Cover very lightly and when the plants are about six inches high, transplant in rows six feet apart each way.

Connecticut Seed Leaf-A long leaf, fine texture. 25 cts. oz.; 75 cts. $\frac{1}{4} \mathrm{lb}$; $\$ 2.75 \mathrm{lb}$.

Havana-Pure Cuban grown seed. 30 cts. oz.; 90 cts. $\frac{1}{4} \mathrm{lb} . ; \$ 3.25 \mathrm{lb}$.

White Burley-A variety largely grown for manufacture of fine cut and plug. 25 cts. oz.; 85 cts. $\frac{1}{4} \mathrm{lb}$.; $\$ 3.00 \mathrm{lb}$.

Zimmer's Spanish-One of the most popular cigar varieties. Very early. $30 \mathrm{cts}$. oz.; $90 \mathrm{cts} . \frac{1}{4} \mathrm{lb}$.

\section{TURNIP (Rueben, Ger.)}

Turnips for early use may be sown as soon as the ground opens in Spring. For Fall and Winter use, sow the early sorts from July to the middle of August, the Ruta Bagas from June to the middle of July. They may be sown either broadcast or in drills. The best crops can be raised from drills, 18 inches apart, and the plants thinned to six inches asunder. One ounce to 150 feet of drill, 1 pound per acre in drills.

Early Purple The best extra early turnip, good quality. 10 cts. oz.; 25 cts. $\frac{1}{4} \mathrm{lb}$; 60 cts. $1 \mathrm{~b}$.

Purple Top Flat Strap LeafThe popular early variety, excel-

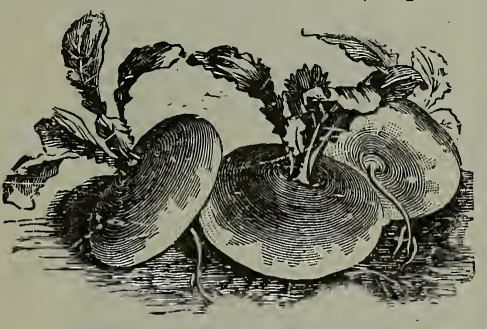
lent for market or private gardens. 10 cts. oz.; 20 cts. $\frac{1}{4} \mathrm{lb}$; 50 cts. $\mathrm{lb}$.

White Flat Strap Leaf-The best early white variety, for table or market use. $10 \mathrm{cts}$. oz.; 20 cts. $\frac{1}{4} \mathrm{lb}$; $50 \mathrm{cts}$. lb.

Long White or Cow Horn-Grows quickly, partly above ground; very productive; flesh white, fine grained and sweet, of excellent quality for family and market gardeners' use. 10 cts. oz.; 20 cts. $\frac{1}{4} \mathrm{lb}$.; 50 cts. lb.

Purple Top White Globe-An early variety, very heavy cropper. 10 cts. oz.; 20 cts. $\frac{1}{4} \mathrm{lb}$; 50 cts. lb.

Yellow Aberdeen-Very hardy and productive, fine form and excellent variety. 10 cts. oz.; 20 cts. $\frac{1}{4}$ lb.; 50 cts. lb.

Seven Top-Very hardy, is left standing in the ground during the Winter in the Southern States, in the Spring yields abundant foliage for greens. $10 \mathrm{cts}$. oz.; 20 cts. $\frac{1}{4}$ lb.; 50 cts. lb.

White Egg-Early, egg shaped, white, fine and sweet. 10 cts. oz.; 20 cts. $\frac{1}{4}$ lb.; 50 cts. lb.

\section{RUTA BAGA or SWEDISH TURNIP}

The Ruta Baga Turnip is extensively grown as a farm crop, the roots are close grained, very hard and will endure a considerable degree of cold without injury, excellent for the table in early spring.

Improved American Purple Top-A fine variety, grown both for table and for stock, flesh solid, fine quality, keeps well until Summer. 20 cts. $\frac{1}{4} \mathrm{lb}$; $50 \mathrm{cts}$. lb.
Carter's Imperial-A purple top, yellow variety, productive, one of the best for field culture. $20 \mathrm{cts}$. $\frac{1}{4} \mathrm{lb}$. $50 \mathrm{cts} . \mathrm{lb}$.

White Sweet German-A white, globe-shaped variety, superior for table use, of excellent quality, good keeper. 10 cts. oz.; 20 cts. $\frac{1}{4}$ lb.; 50 cts. lb.

\section{HERB SEEDS.}

Sow early in April or May, in a sheltered, well-prepared spot in the open ground, either broadcast or in shallow drills about seven inches apart. Thin out the plants thus raised, and keep clear from weeds. A few sweet aromatic and medicinal herbs are very valuable for flavoring soups, etc., and care should be taken to harvest them properly on a dry day, as they come into full blossom, then dry quickly and pack closely, entirely excluding the air.

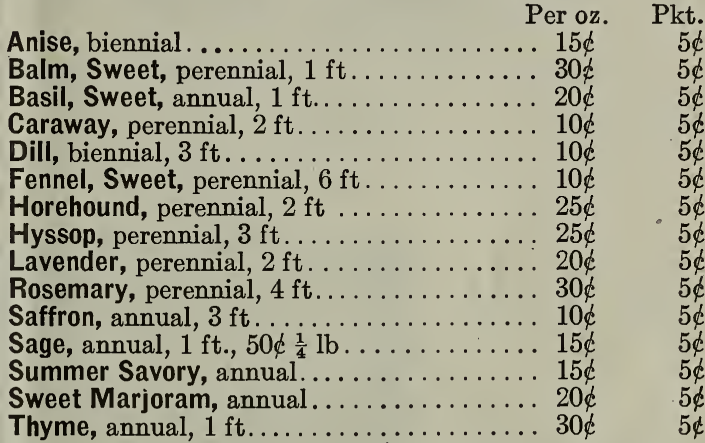

\section{VEGETABLE PLANTS AND ROOTS}

As we grow these plants ourselves, they are always well packed and can be shipped fresh from beds on short notice Prices Do Not include Prepayment by Mail or Express.

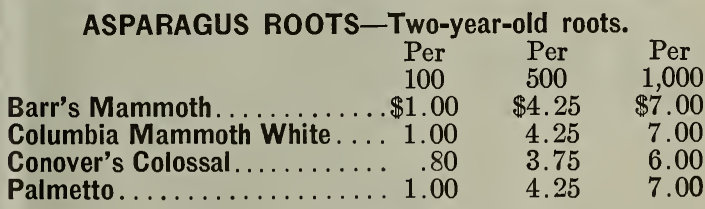
Palmetto

EARLY CABBAGE PLANTS.

(Ready about April 1st.) Per

100

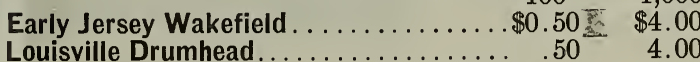

Per

4.00
4.00

\section{LATE CABBAGE PLANTS.}

(Ready in June.)

Large Late Drumhead............... . $30 \quad 2.50$

Premium Flat Dutch...................... . $30 \quad 2.50$

\section{CAULIFLOWER. Per Per}

(Ready May 1st.) doz. 100

Henderson's Snowball . . . . . . . . . . \$0.25 \$1.50

Early Dwarf Erfurt. . . . . . . . . . . . .25 1.50

CELERY PLANTS.

(Ready June to August.) Per Per

$100 \quad 1,000$

White Plume. . . . . . . . . . . . . . . \$0.50 \$3.50

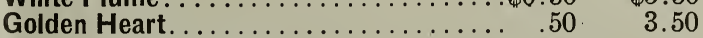

Golden Self-Blanching. .............. .50 3.50

CHIVES.

Per

Good clumps $\ldots \ldots \ldots \ldots \ldots \ldots \ldots \ldots \ldots \$ 0.10 \quad \begin{aligned} & \text { Each } \\ & \$ 1.00\end{aligned}$

$\begin{array}{ccc}\text { EGG PLANTS. } & \text { Per } & \text { Per } \\ \text { (Ready in June.) } & \text { doz. } & 100\end{array}$

New York Improved..............\$0.40 \$2.50

PEPPER PLANTS.

(Ready June 1st.) I Per Per

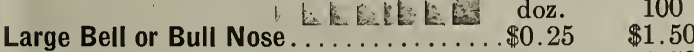

Ruby King................... 


\section{VEGETABLE PLANTSAND ROOTS-Cont'd. RHUBARB ROOTS. (Ready April 1st.) \\ Single Eye. . Large Clumps. \\ Per \\ doz. \\ $\$ 0.50$ .25}

\section{SWEET POTATO PLANTS.}

(Ready early in June.)

Nansemond Yellow

Jersey Yellow

Red Bermuda.

Southern Queen.

\section{Per} 100

$\$ 0.30$

.30

.35

.35

\section{TOMATO PLANTS.}

(Ready about May 1st.)

Acme, Beauty, Stone, Dwarf, Champion, Buckeye State, Trucker's, Favorite, Ponderosa. $\quad$ Per Per Transplanted .................\$0.20 \$1.50 From hot-beds transplanted . . . . . . . . $15 \quad 1.00$

\section{HORSE RADISH SETS.}

Per Dozen........................... $\$ 0.15$

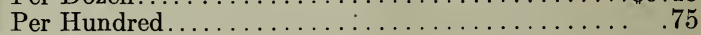

Per Thousand ....................... 6.00

\section{Our Celebrated Emerald or City Park Lawn Grass Seed}

This Seed is Equal or Superior to any Lawn Grass Seed offered under any Name
$1 / 2$ lb. 15 cts.
$1 \mathrm{lb} .25$ cts.
2 lbs. 50 cts.
5 lbs. $\$ 1.00$
16 lbs. (1 bu.) $\$ 3.00$

( 5 cts. $\frac{1}{2} \mathrm{lb}$., and $10 \mathrm{cts}$. per lb. extra if sent by mail.)

THIS LAWN MADE FIRST YEAR FROM OUR SEED.

\section{S E E D \\ Y O UR}

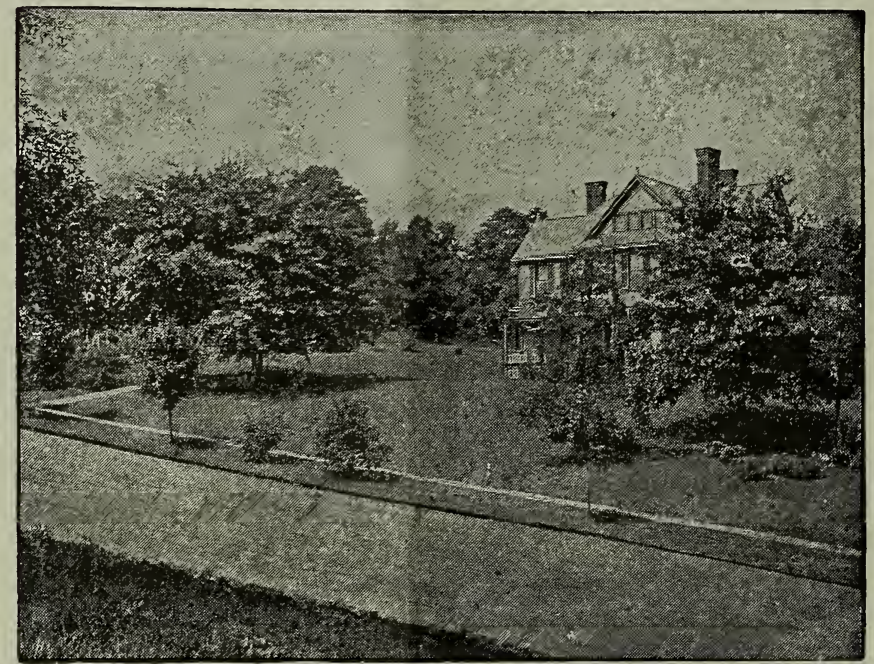

USE đ̄NO

\section{Emerald}

\section{A W N}

L A W N

$\mathrm{N} O \mathrm{~W}$

Residence of J. CHAS. McCULLOUGH

Is composed exclusively of the very best varieties of grass, such as long experience has shown to be best adapted to produce a thick, heavy, carpetlike lawn. In this mixture we use only the very best recleaned seed. One of the greatest troubles in obtaining a good lawn is to get it free from weeds. These, while not always in the seeds, but quite often in the ground, or come from the use of stable manure, are nevertheless, always objectionable. Our customers can rely, in buying Our Emerald Lawn Grass Seed, on its being the very purest seed obtainable.

Directions for the Lawn-First get the ground in the desired shape and grade, drain it where necessary and pulverize the soil, removing roots, stones, etc., so as to have an even and smooth surface. To secure the best results use our seed liberally. Four to five bushels per acre for new lawns being about the right quantity. (One pound to about 300 square feet.) Two to three bushels for renovating.

Let the grass get a start of three or four inches before cutting, as the growth is retarded by too early cutting. After this it should be cut with a lawn mower every ten days and rolled whenever the ground is soft enough for the roller to make an impression.

WIZARD Brand Pulverized Sheep Manure makes the lawn bright, green and velvety, a thick heavy turf of strong healthy grasses. It is better in every way than rough stable manure for top dressing, and brings no weeds. It is easily applied and does not have to be raked off.

Application.- Scatter broadcast on a day when there is little wind at the rate of from 300 to 500 pounds per acre of lawn. In dry, hot weather, it is best to wet down thoroughly after applying. Pleasing results are sure to follow. 10 cts. lb.; 5 lbs. 25 cts.; 10 lbs. 40 cts.; 50 lbs. $\$ 1.00$; per bag of 100 lbs. $\$ 1.75$.

PERMANENT GRASS SEED FOR GOLF LINKS.-We have always on hand all the valuable natural grasses of Europe and America, and we are familiar with the habits and merits of each. We shall be glad to prescribe for whatever the requirements of the Links may be, for poor land or rich, high and dry, or low and wet.

Golf Link Mixture.-For the grounds in general, per bushel, (16 lbs.) $\$ 2.50$.

\section{The Best Lawns and Grass Plots are made from Seed}

A good, green, velvety lawn or grass plot is the richest embellishment that a home can possess. Once seeded with the best lawn grass seed that can be mixed (our Emerald or City Park Lawn Grass Seed), it is permanent for years to come, although an occasional reseeding is advisable, as it keeps the lawn in the best condition. 


\section{Special Grasses for Lawns, Terraces, Golf Links and Putting Greens.}

\section{OUR LAWN GRASS MIXTURE FOR SHADY SITUATIONS.}

On nearly all lawns there are shaded, bare and unsightly spots on which the owners have difficulty in getting a stand of grass. For such places this mixture is adapted. It is composed of dwarf-growing grasses which are found naturally growing in such places. Should the ground have become "sour" or drainage defective, it is apt to be covered with moss. If such is the case, apply Hard Wood Ashes to sweeten it, after first removing the moss, then rake thoroughly and sow the seed at the rate of not less than 4 bushels per acre. Per lb. 30 cts.; 4 lbs. $\$ 1.00$; bu., (16 lbs.) $\$ 3.50$.

If to go by mail, add to the above prices $10 \mathrm{cts}$. per lb. for postage.

\section{TERRACE MIXTURE.}

A mixture of grasses with long interlacing, matting roots, that will bind steep embankments, gravelly or sandy slopes, etc., preventing washouts by rainstorms and covering with permanently green turf. Per lb. 30 cts.; 4 lbs. $\$ 1.00 ; 1$ bu. of $16 \mathrm{lbs}$., $\$ 3.50$. By mail 10 cts. per lb. extra.

\section{GOLF LINK MIXTURE.}

For the grounds in general. Per lb., 20 cts.; 5 lbs., 90 cts.; 1 bu. of 16 lbs., $\$ 2.50$. By mail, 10 cts. per lb. extra.

\section{PUTTING-GREEN MIXTURE.}

A mixture of extra fine grasses, that will make a close, firm, green and lasting turf, which will improve with trampling. Per lb., 30 cts.; 4 lbs. $\$ 1.00 ; 1$ bu. of 16 lbs., $\$ 3.50$. By mail, 10 cts. per lb. extra.

\section{PACEY'S SHORT RYE GRASS.}

A selection of Perennial Rye Grass, particularly well adapted for lawn and pasturage purposes, making a quick, leafy growth of fine texture. Sow early in spring at the rate of one to one and a half bushels per acre. Lb., 20 cts.; bu. (of 24 lbs.) $\$ 2.50$.

\section{CREEPING BENT GRASS (AGROSTIS STOLONIFERA.)}

Particularly valuable for lawns that are to be used as croquet and tennis grounds because it is benefitted more than hurt by trampling, and by its bright color adds to the beauty of the lawn. Lb. 30 cts.; 100 lbs., $\$ 25.00$.

\section{RHODE ISLAND BENT GRASS (AGROSTIS CANINA.)}

A valuable perennial for lawns and pasturage. Much like Red Top, though smaller. Thrives on light, dry soils as well as on rich, moist ones. For lawn purposes, if used alone, it should be sown at the rate of about forty pounds per acre; for pasture, if used alone, twenty-four pounds per acre. Lb., 30 cts., 100 lbs., \$25.00.

\section{CRESTED DOGS-TAIL (Cynosurus cristatus.)}

May be sown on lawns, forms a close turf, remaining green a long time; valuable for sheep pasture; succeeds on dry and hard gravely soil. Height, 1 to $1 \frac{1}{2}$ feet. Sow 25 lbs. per acre (bu. 21 lbs.) Lb. 40 cts.; 10 lbs. $\$ 3.50$.

\section{ITALIAN RYE GRASS.}

An early rapid grower, producing large leaves and succulent food. It does best in moist soils. Sow early in spring or fall about $25 \mathrm{lbs}$. per acre. $15 \mathrm{cts}$. lb.

\section{Mixed Grasses for Meadows and Pastures.}

We are prepared to furnish seeds adapted to all soils and all situations and for all purposes. Our best mixture is made entirely with choice, recleaned seeds, while in the second quality we use the same seeds, but without recleaning and will be equal to the qualities usually to be had on the market. Our mixtures will have a uniform weight of $16 \mathrm{lb}$. to the bushel. Quantity to be used per acre, $1 \frac{1}{2}$ to 2 bushels, and half this quantity for renovating. In ordering always state the soil and position on which you wish to use it. 2 bushel seamless bags, 21 cts. each. No extra charge for burlap bags for 5 bushels or more.

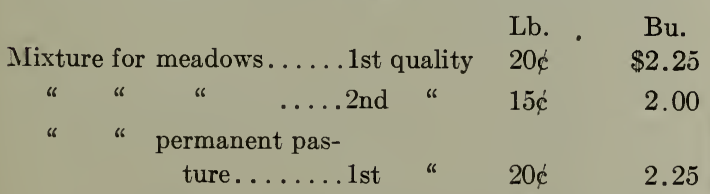

\begin{tabular}{|c|c|c|c|c|c|}
\hline Mixt & & $\begin{array}{l}\text { permanent pas- } \\
\text { ture.......2nd }\end{array}$ & $\underset{\text { quality }}{\text { q }}$ & $\begin{array}{l}\text { Lb. } \\
15 \mathrm{c}\end{array}$ & $\begin{array}{l}\text { Bu. } \\
\$ 2.00\end{array}$ \\
\hline “ & “ & $\begin{array}{l}\text { pasture and hay } \\
\text { in orchards } \\
\text { and other } \\
\text { shady places. 1st }\end{array}$ & “ & $20 \dot{c}$ & 2.25 \\
\hline " & “ & $\begin{array}{l}\text { pasture and hay } \\
\text { in orchards } \\
\text { and other } \\
\text { shady places.2nd }\end{array}$ & “ & $15 c$ & 2.00 \\
\hline “ & “ & marshy grounds 1 st & “ & $20 \dot{c}$ & 2.00 \\
\hline “ & “ & 2nd & “ & $15 c$ & 1.75 \\
\hline " & " & $\begin{array}{l}\text { sandy and rocky } \\
\text { grounds....1st }\end{array}$ & “ & $20 \dot{c}$ & 2.00 \\
\hline " & " & $\begin{array}{l}\text { sandy and rocky } \\
\text { grounds....2nd }\end{array}$ & “ & $15 \grave{c}$ & 1.75 \\
\hline
\end{tabular}

Special Prices on Large Quantities.

We are one of the Largest Recleaners of Seeds in the U. S. Our facilities unsurpassed. 


\section{Recleaned Grass and Clover Seeds.}

This department has been our leading specialty for many years. Our building is one of the largest, best equipped and most conveniently situated in the State, containing over 125,000 square feet of floor space, which, with the addition of the best improved machinery, makes our capacity about ten times greater than before. Our facilities can not be excelled.

We now run by power 21 improved combined cleaners and separators, also power corn shellers, etc.

No seed firm in this country takes greater pains and care in the purchase and sale of grass seeds handled than do we, and none have experts of greater knowledge or better judgement. The men in charge of buying, cleaning and grading have all had more than twenty years' experience in our own establishment. We also have the latest and best cleaning machinery and thus equipped we are in position to furnish and do furnish the very highest possible quality in this line.

As the prices are constantly changing, quotations are subject to market fluctuations. Where customers are in need of large quantities, we will be pleased to quote lowest market prices. All orders with cash filled at the lowest market price on day of receipt.

2 bushel Burlap Bags, 10 cents each. 2 bushel Seamless Cotton Bags, 21 cents each.

10 cents per pound extra if sent by mail.

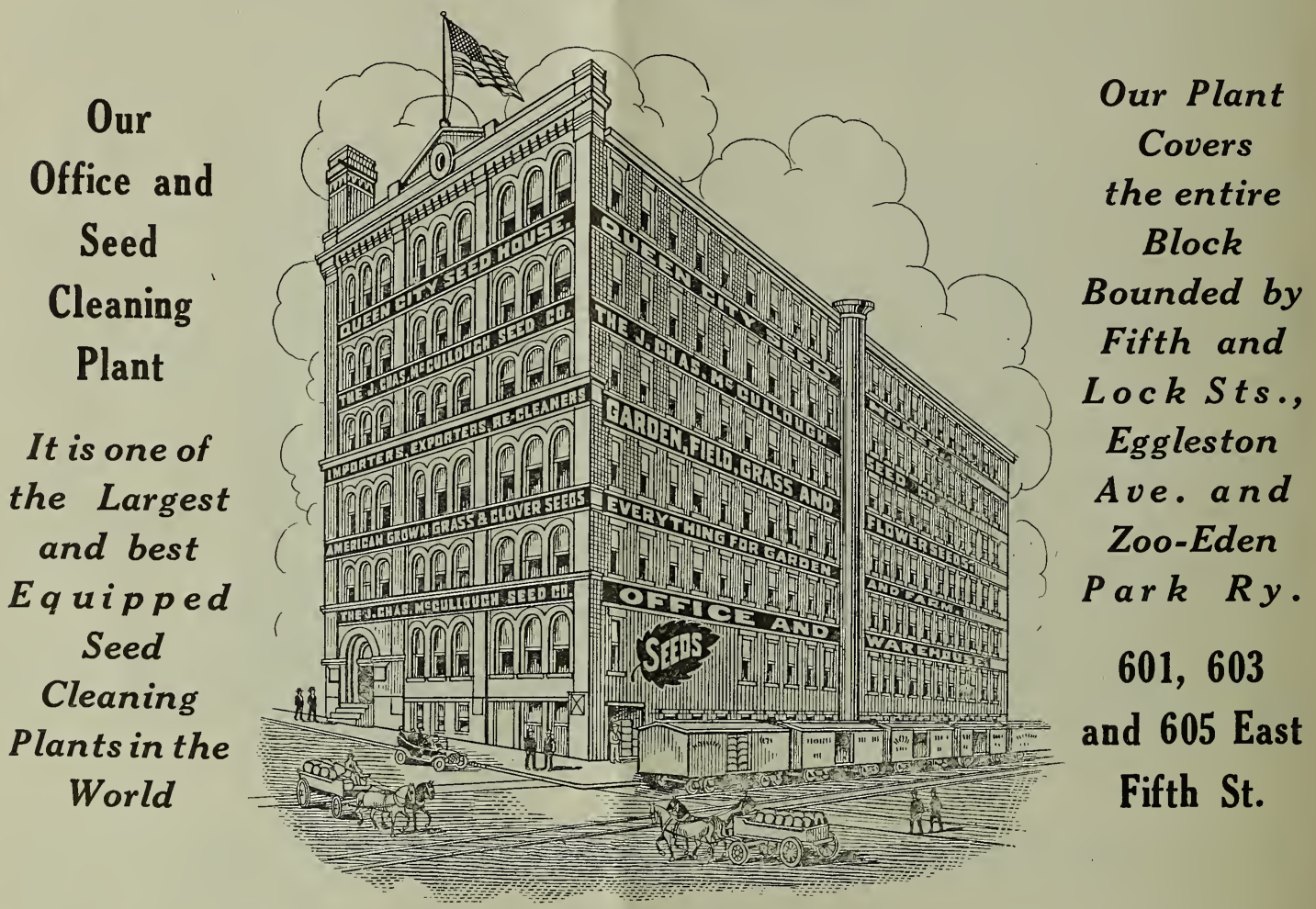

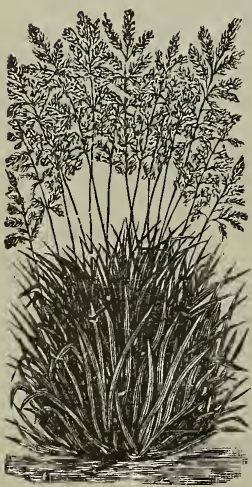

\section{KENTUCKY BLUE GRASS}

This grass is almost universally known, and furnishes a moderate supply of pasture of the best quality. It varies in appearance and size according to soil, and in some parts of the country grows spontaneously. It stands drought very well, and if allowed to grow up in fall without grazing, makes a good winter pasture. Sow in fall or spring at the rate of two to three bushels per acre.

Fancy, 20 cts. lb.; 1.50 to $\$ 2.00$ bu. lots.

Write for special prices on large

Canadian Blue Grass. (Poa Compressa)-Also called flat-stemmed poa, Flat-stalked Meadow Grass. Grows a foot or more high. Recommended for horses, cows and sheep. Thrives well on clay. Sow $30 \mathrm{lbs}$. per acre. 15 cts. lb.; $\$ 1.50$ bu.

\section{PERENNIAL RYE GRASS}

(Imported English Blue Grass.)

Is considered quite valuable, as it affords pasture quite early in spring. The leaves are flat, long and glossy; the stalks rather short, seldom over 18 inches in length. The seeds are large, strong and make a vigorous young plant soon after sowing. The grass is quite variable in size and appearance. Sow early in Spring at the rate of one to one and a half bushel per acre. 20 cts. lb.; $\$ 2.50 \mathrm{bu}$.

Italian Rye Grass-An early rapid grower, producing large leaves and succulent food. It does best in moist soils. Sow early in spring or fall about 25 lbs. per acre. 15 cts. lb.

Sheep's Fescue-Grows naturally on light, dry, sandy soils and mountain pastures. It is considered quite valuable as a mixture with other grasses for permanent early spring pasture. 25 cts. lb. 


\section{GRASS SEEDS-Continued}

\section{MEADOW FESCUE}

This thrives in all soils, excellent for permanent pasture, starts early and is very productive; grows two to three feet high, and does well in almost any soil; makes fair hay. Sow in September or early in spring, at the rate of one to one and a half bushel per acre.

Extra Fine, 35 cts. lb.

Second Grade, $30 \mathrm{cts}$. lb.

\section{ORCHARD GRASS}

One of the very best grasses in cultivation, and rapidly coming in favor. If cut just at the coming into bloom (as it always should be) a good second crop will follow and sometimes even a third. Is recommended for sowing with red clover as they come into flower at the same time. Orchard Grass is one of the earliest grasses, yields immense crops, and makes the best of hay; it endures considerable shade, and is much used for sowing in orchards. $1 \frac{1}{2}$ to 2 bushels of seed will sow an acre. 15 to 20 cts. lb.; $\$ 1.50$ to $\$ 2.50 \mathrm{bu}$.

\section{RED TOP}

This perennial native grass produces rather late in the season a

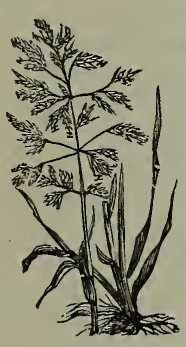
reddish purple, or greenish panicle of flowers. It thrives best on low lands, where it cuts a good

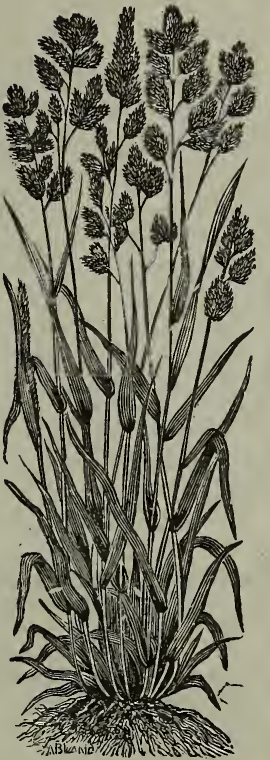
crop of rather light hay of fair quality. It is very suitable for pastures on low ground. Sow in September or early spring at the rate of 1 to $2 \mathrm{bu}$.per acre.

Fair, 10 cts. lb.; $\$ 1.00$ bu.

Choice, 15 cts. lb.; $\$ 1.75$ bu.

Fancy, 25 to 30 cts. lb.

Timothy-This grass stands at the head for meadows, particularly for hay that is to be baled for market, if cut at the proper time, which is, when in full bloom. We prefer to seed it in the fall-September- if it is seasonable. and if, by any reason, there is a partial failure, go over the ground in spring. Sow one fourth to one-half bushel seed per acre. Market price.

Sweet Vernal-Is very fragrant, especially when bruised. For a mixture with other grasses for pasture it is quite valuable, as it starts early in spring and grows until late in the fall. For hay its chief merit is its fragrant odor. It is a vegetable condiment rather than a grass of nutritive value. $25 \mathrm{cts}$. $\mathrm{lb}$.

Bermuda Grass-A very valuable grass for the south, butwill notendure frost. $\$ 1.25 \mathrm{lb}$.

Johnson Grass-A perennial, a rapid grower, long, cane-like roots, the leaf stalk and panicle of this grass resembling those of other Sorghums. Sow at the rate of one bushel per care, and should be sown in August or September to secure a good crop the following year. 25 cts. lb.

Tall Meadow Oat GrassThis is a perennial grass, has broad, flat leaves and grows about 3 feet high, has an

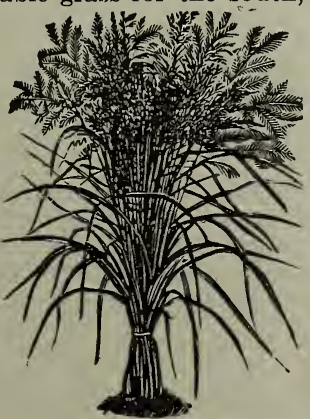

abundance of long fibrous roots penetrating deeply in the soil enabling it to withstand drought and cold. Sow at the rate of two bushels per acre, in early fall, on sheep pastures. $30 \mathrm{cts}$. lb.

Wood Meadow Grass-This grass; as its name implies, is found naturally in shady woods, and is well adapted to growing under trees, but will also on exposed places and on light, thin soil. $60 \mathrm{cts}$. lb.

German or Golden MilletTrue Southern grown.- It has been fully established that German Millet grown in the Northern and Western States becomes deteriorated, and soon resembles Fox Tail in quality and yield. This is due to the fact that German Millet is a native of a warm climate. Southern grown seed is worth double that of Northern or Western grown, if you want a good crop of hay. We are prepared at all times to fill orders at market prices.

\section{Japanese Barnyard Millet-} It has proven an enormous yielder in all sections of the United States, producing hay and fodder to a height of 6 to 8 feet, and produces from 12 to 20 tons per acre. Cattle and horses eat it greedily and fatten rapidly. It is a remarkable stooler and should not be sown very thickly-10 to 12 pounds per acre broadcast being sufficient. In drills, $8 \mathrm{lbs}$. per acre is plenty. Lb., $10 \mathrm{cts}$; $10 \mathrm{lbs}$. 75 cts.

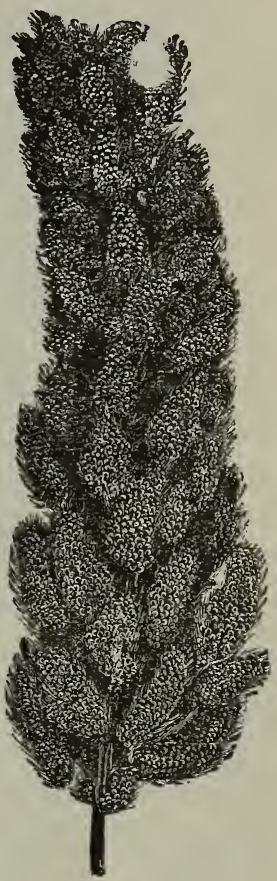

\section{Missouri or Common Millet-Market price.}

Hungarian Grass-This grass resembles the millet, it is of fine growth, and makes an excellent hay. Market price.

\section{CLOVERS}

Red Clover-In ordering always state quality desired, otherwise will send the best. The grades of the market are EN Best, Special and Export. Market price.

Sapling, Mammoth, Large, English or Pea Vine CloverTrifolium Pratense Perenne. Compared with common red clover, its flowers, foliage and stems are of a darker color and its seed is the product of the flowers of the first crop, while the common red clover is the product of the flowers of the second crop. It is valuable when sown with other grasses for mixed hay, as it ripens later than the common red clover and about the time that timothy, orchard and other grasses ripen, thereby making the hay a much better quality. The best for soiling purposes. Market price.

Japan Clover-(Lespedeza Striata.) It thrives on poor land and produces continual herbage. Not adapted to Northern latitudes, as it is only half-hardy. Sow 10 to 12 lbs. per acre. 40 cts. $\mathrm{lb}$.

White Dutch Clover-(Trifolium Repens.) Grows naturally in pastures in a great variety of soils and situations and is an indespensible requisition in all parks and lawns. $50 \mathrm{cts} . \mathrm{lb}$.

We are not only sellers, but one of the largest "cash" buyers of every variety of GRASS and FIELD SEEDS, Fancy Seed Grain, etc. Would be pleased to receive Samples of any Fancy Stock you may have to offer. 


\section{CLOVER SEED-Continued}

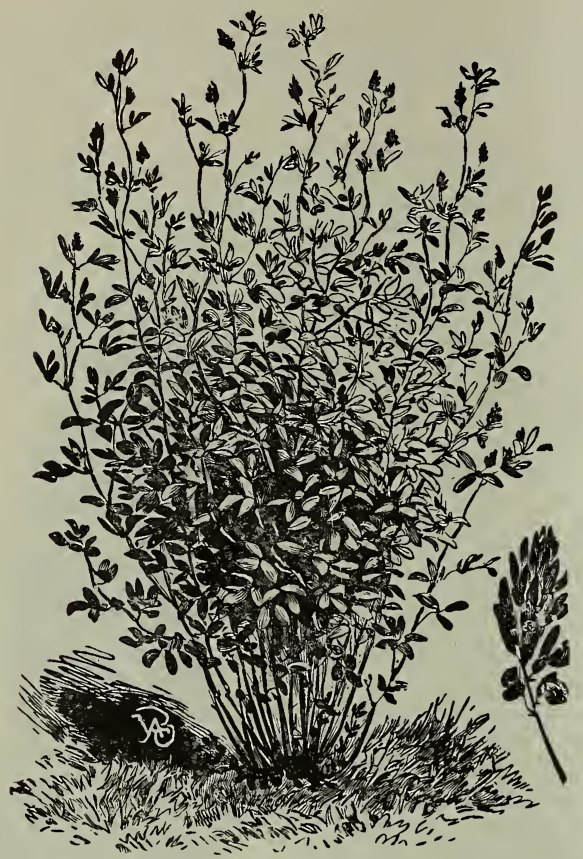

Alfalfa Clover-The most valuable forage plant. It thrives best on a sandy loam. the richer the better, and in such will produce several crops every season. In the driest and most sultry weather, when every blade of grass withers, Alfalfa is as fresh and green as in the spring, as its roots go down from 10 to 20 feet to the moisture of the ground. Although a prodigious yielder, it does not exhaust the soil, but rather improves the ground by the decay of its long roots, and converts it into rich ground, full of vegetable matter. The seed may be sown early in the spring. Sow twenty-five pounds per acre. $25 \mathrm{cts}$. $\mathrm{lb}$.

Alsike or Swedish Clover-So-called from being intermediate in its appearance between the red and white clovers, possessing qualities common to both, being productive, sweet and permanent. Will grow well on very poor soil. Should be used in mixtures of grasses and clovers for pasture, and will improve the quality of the hay if mixed with the meadow grasses. It is also esteemed highly for pasturage for bees. $25 \mathrm{cts}$. lb.

Sweet Clover, or Bokhara-White and Yellow Flowered A variety of Clover that resembles Alfalfa both as to appearance and habit of growth when young. It grows much larger than Alfalfa. Is valuable in the bringing up old waste and worn-out soils, and thrives well even on extremely poor soil. If $\rho$ lowed under it adds humus and nitrogen to the soil, or if simply left to grow up and drop back for a few years the decaying stalks and roots will do wonders for the land. Sweet Clover will thrive on all classes of soil and will inoculate land otherwise too poor to establish Alfalfa.

\section{Makes Good Hay.}

The hay is cured very much like alfalfa, and if cut at the proper time (that is just before the plants bloom) makes a very nutritious hay which is equal to alfalfa hay in feeding value. Sown before April, two cuttings are obtained the first year. One crop of hay and a crop of seed, or two crops of hay are usually cut the second year. Yields vary from $2 \frac{1}{2}$ to 5 tons per acre. Sow at the rate of 15 to 25 lbs. per acre. 25 cts. lb.; $\$ 20.00100$ lbs.
Scarlet or Crimson Clover-Scarlet Clover is an annual and should be sown in August, September or October. It germinates quickly, grows very rapidly through the fall and winter, blossoms about May 1st. This clover can be sown after crops have been removed from the ground. In this way it will prove of inestimable value in holding the valuable nitrates in the soil that are otherwise washed out of the bare ground, furnishes fall, winter and spring pasture and enriches and stores up plant food for the next crop. Sow at the rate of ten or fifteen pounds per care, covering with harrow or cultivator. $20 \mathrm{cts}$. $\mathrm{lb}$.

\section{SEED CORN / J}

(2 bu. Seamless Bags 21 cts. each.)

Clark County Champion-A white dent corn, extra early, good yielder 40 cts. peek; $\$ 1.40$ bu.

Extra Early Huron Dent Corn-Earlièst Dent Corn in the United States. Of a bright orange color, has good size stack and ear, small red cob; long deep grain, rank strong growth and wonderful productiveness. 40 cts. peck; $\$ 1: 40 \mathrm{bu}$.

Champion White Pearl-The best white dent corn in cultivation, will ripen in 90 to 100 days, ears of good size, enormously productive. 40 cts. peck; $\$ 1.40 \mathrm{bu}$.

Improved Leaming Yellow-Ears of good size, cob red and small, a strong grower and very prolific, a standard variety. 40 cts. peck; $\$ 1.40 \mathrm{bu}$.

Silver Mine-One of the best yielding While Dent Corns. Cylindrical shape, tapering a little at the tip end; 18 to 20 rows; kernels deep and cobs small. A fine shelling and high yielding variety. 40 cts. peck; $\$ 1.40$ bu.

lowa Gold Mine-Early yellow dent, ears are of good size and symmetrical, color a bright, golden yellow, grain is very deep, cob small, and therefore dries out very quickly as soon as ripe. $40 \mathrm{cts}$. peck; $\$ 1.40 \mathrm{bu}$.

Red Cob Ensilage-A southern type of large, white corn, with red cob, strong, leafy stocks, and short joints, a general fayorite, 35 cts. peck; $\$ 1.25 \mathrm{bu}$.

Ensilage Corn, White-35 cts. peck; $\$ 1.25$ bu.

Ensilage Corn, Sweet-There is nothing better for early fall green feed, or for curing for winter than sweet corn. It has the great merit of being so sweet and palatable that cattle eat every part of the stalks and leaves, and consequently, none is wasted. A favorite with dairy farmers. Also excellent for soiling. Can be planted as other corn or sown thîckly in drills. $50 \mathrm{cts}$. peck.

Hickory King-A white field corn which has the largest grains with the smallest cob of any white corn ever introduced. So large are grains and so small the cob that on an ear broken in half a single grain will almost cover the cob section completely. Of strong, vigorous growth and yields splendid crops on light soil; a desirable variety where season is long enough to mature it. 50 cts. peck; $\$ 1.75 \mathrm{bu}$.

\section{CHOICE SEED OATS}

(Burlap Bags, 2 to 4 bu. 10 cts. each.)

Red Rust-Proof-This is the standard oats of the Southern States, yielding large crops when all other sorts were destroyed by rust. It is a large, heavy, reddish looking berry, very prolific.

Winter Turf-Perfectly hardy in the Southern and Middle States. Yields on good land, from 50 to 70 bushels to the acre of fine, heavy grain, weighing from 35 to 50 pounds to the measured bushel.

White, Black, also Mixed-Market price.

\section{SEED WHEAT}

Longberry Red, Fultz, and other varieties-Market 


\section{Seeds For the Farm.}

By express or freight at buyer's expense. $10 \mathrm{cts}$. Ib. extra if sent by Mail. The prices quoted are subject to change.

\section{SPRING WHEAT AND BARLEY}

Canada Spring, Northwestern Spring Wheat, Fall and Spring Barley-Market price.

\section{BUCKWHEAT}

Japanese and Silver Hull-5 cts. lb.; $\$ 1.50$ bu.

Common Gray -5 cts. lb.; $\$ 1.50$ bu. Subject to market changes.

\section{FIELD PEAS}

\section{(2 Bushel Seamless Bags, 21 cts. each.)}

Canada Field Peas-Grown with Oats makes a fodder or hay which doubles the production of milk. They should be sown in March or early April, two bushels of peas and two bushels of oats to the acre. The peas should be sown first and plowed under about 4 inches deep; the oats then sowed and harrowed in. They will be ready for cutting about the latter end of June when the oats are in milk and the pods formed on the peas. Prices variable, but always as low as the market will permit. 65 cts. peck.

\section{SOUTHERN COW PEAS}

Save Fertilizer Bills and Improves the Condition of Soils Wherever Sown. Also Makes a Splendid and Nutritious Green Forage or Hay Crop.

There is no surer or cheaper means of improving and increasing the productiveness of our soils than by sowing the Cow Pea. It makes an enormous growth, enabling the farmer to put plenty of nitrogenous vegetable matter into the soil at a small cost, and so very largely enables him to dispense with the use of nitrogenous fertilizers. The Cow Pea, to a greater extent than other leguminous crops, has the power to extract this costly nitrogen from the atmosphere and to store the same in the vines and roots so that if the crop is cut off, the land is still enriched and its condition improved. From 5 to 15 tons of green fodder per acre have been produced by the Cow Pea. To grow for hay they are most valuable, as they yield an immense quantity of feed of the best quality. For ensilage they are unsurpassed. Where it is desired to turn the whole crop under, as a soil improver, it is better to do so after the vines are partly dead. A good picking of the dried peas can be made before plowing under, if desired. Cow Peas can be sown in May or June, at the rate of one to one and a half bushel per acre.

Wonderful Black Eye and Brown Eye-Produce largest crop of vines. $85 \mathrm{cts}$. peck.

Clay and Black-Best for combination crop vines and peas. $85 \mathrm{cts}$. peck.

New Era and Whippoorwill-Best for peas, recommended for "hogging down." 85 cts. peck.

\section{SOJA, OR SOY BEANS}

The Soja Bean is fast taking the place of Clover in sections where the soil is not the most fertile, both for hay and fertilizing purposes.

Recommended as the best leguminous plant for soil restoring as it is adapted to all soils. It is a sure cropper. Unsurpassed for hay, claimed to be superior to Clover or
Timothy. Plant in May, for it takes about ninety days to mature the hay and one hundred and twenty days to mature the seed. For hay sow about one bushel per acre either broadcast or drilled. Cut when in blossom. For seed sow in drills about twelve inches apart in the rows and have the rows about thirty inches apart. 75 cts. peck.

\section{SUNFLOWER}

Mammoth Russian-May be grown to great advantage in waste ground, from early spring to the latter part of July. An excellent and cheap food for fowls. Plant four quarts to acre. $10 \mathrm{cts}$. lb.; $\$ 5.00$ per $100 \mathrm{lbs}$.

\section{BROOM CORN}

Improved Evergreen-The best for general cultivation, brush firm, of good length and bright green color. $10 \mathrm{cts}$. lb.

Dwarf-Grows from 3 to 4 feet high, with straight brush 10 cts. $1 \mathrm{~b}$.

California Golden-A strong growing variety much resembling the Evergreen, but longer brush, and a bright golden color when ripe. $10 \mathrm{cts} . \mathrm{lb}$.

\section{SORGHUM OR SUGAR CANE}

Orange Cane-A strong grower, much more juicy than any other variety, the stalk is heavier and a little earlier than the Amber. 10 cts. lb.

Amber Cane-This popular and well-known variety makes the finest quality of both sugar and syrup. $10 \mathrm{cts} . \mathrm{lb}$.

Imphee or Red Top-An old standard sort, and undoubtedly one of the best that has ever been introduced. $10 \mathrm{cts} . \mathrm{lb}$.

\section{KAFFIR CORN}

A variety of Sorghum, forming low, stocky and erect plants, producing from 2 to 4 heads of grain on each stalk, heads long and narrow, and filled with white grain which are greedily eaten by all farm animals, matures about the middle of October, resists drought like most Sorghums and furnishes excellent fodder, cultivate same as corn. $10 \mathrm{cts}$. lb.

\section{SPRING VETCHES, OR TARES}

\section{(Vicia Sativa.)}

A species of the pea grown extensively in England, and to a considerable extent in Canada, for stock. Culture same as Field Peas. Sow $1 \frac{1}{2}$ bushels per acre. $10 \mathrm{cts} . \mathrm{lb}$ Write for price per bushel.

\section{SAND, WINTER OR HAIRY VETCHES}

\section{(Vicia Villosa.)}

A very hardy forage plant, growing well on soils so poor and sandy that they will produce but little clover. The plants when mature are about 40 inches high, and if cut for forage as soon as full grown and before setting seed, they will start up again and furnish even a larger crop than the first. Sow 1 bushel to the acre. $15 \mathrm{cts}$. lb. Write for price per bushel. 


\section{MISCELLANEOUS FARM SEEDS.}

\section{DWARF ESSEX RAPE}

A forage plant of highest value. It can be sown in April for an early crop, and for fall crop in July, August and September, and still later further south. It is sown broadcast $6 \mathrm{lbs}$. to the acre, but is better drilled, in which case $3 \mathrm{lbs}$. to the acre will suffice. In a few weeks from the time of sowing, sheep, hogs or cattle can be turned on it; all reports agree that they gain weight faster on this than any other fodder, as it can be sown after other crops are off; the gain in fodder is secured at a nominal cost. Stockmen, Dairymen and Farmers have proved its value. 10 cts. lb.; $\$ 7.50$ per 100 lbs.

\section{TEOSINTE}

\section{(Reane Luxurians.)}

The stalk can be cut several times during the season. Should not be planted until the soil is perfectly warm in spring. Requires about $4 \mathrm{lbs}$. of seed per acre. 75 cts. lb.; $\$ 3.255 \mathrm{lbs}$.

\section{SPELTZ (EMMER)}

Introduced into this country from Russia, where its value as a cereal has long been esteemed. Very heavy crops of it have been reported from many sections of the country. It appears to do better than any other grain crop on poor, thin soil, and in the extremely dry seasons. It is eaten greedily by all kinds of stock, including poultry, and its feeding qualities are said to be excellent. Sow broadcast same as oats, using about 75 lbs. to acre. Lb., 10 cts.; 10 lbs., 50 cts.; bu. of 40 lbs., $\$ 1.50$.

\section{PEACH PITS}

We have for years made the handling of peach pits a specialty, annually securing our stocks from districts entirely free from the yellows and are prepared to furnish the best. Prices furnished on application.

\section{MOCKING BIRD FOOD}

For Thrushes, Mocking Birds, Black Birds, Nightingales and all soft billed birds. Directions for use on each package. 35 cts. per package.

\section{TRADE FARMOGERM MARK}

\section{The Standard Inoculation.}

\section{IS ENDORSED BY EXPERIMENT STATIONS AND AGRICUL- TURAL EXPERTS EVERYWHERE.}

A preparation of high-bred, nitrogen-gathering bacteria in sealed bottles, ready to use, with water added according to directions. Prepared for the following crops:

Red Clover

Alsike Clover

Alfalfa Clover

\section{Canada Field Peas Garden Peas \\ Soy Beans}

Price per acre bottle, $\$ 2$; per five-acre bottle, $\$ 9$. State for what crop Farmogerm is wanted, when ordering.

Also in garden size, enough for 1,000 square feet or a 200 -foot row. for Garden Peas and Beans, at 50 cts. per bottle. We secure cultures fresh from the laboratory, hence it takes two or three days to fill orders.

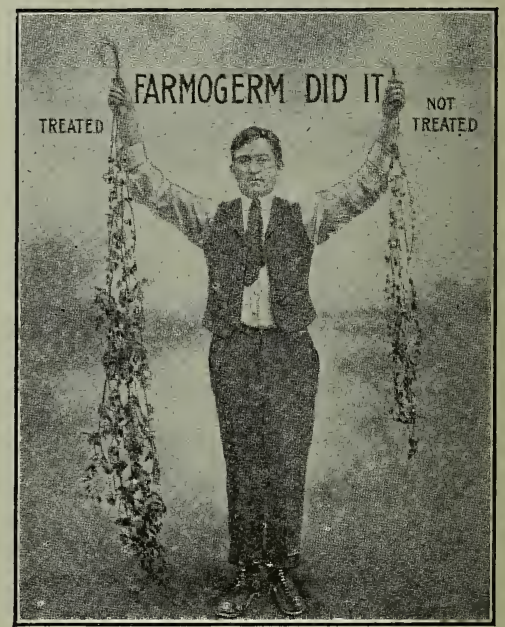

\section{MISCELLANEOUS, BIRD AND SUNDRY SEEDS.}

Ten Cents per Pound Extra, if Sent by Mail.

Per lb.

Black Locust......................\$0.40

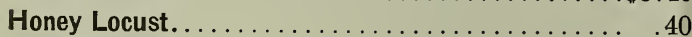

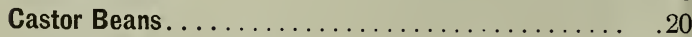

Canary Seed $(3 \mathrm{lbs} .25 \phi) \ldots \ldots \ldots \ldots \ldots \ldots \ldots \ldots \ldots, .10$

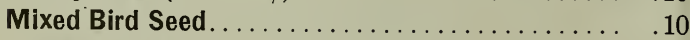

Caraway Seed . . . . . . . . . . . . . . . . . . . . . 15

Celery Seed, for flavoring $\ldots \ldots \ldots \ldots \ldots \ldots \ldots \ldots \ldots . \quad .50$

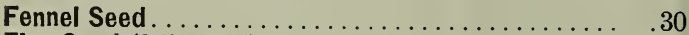

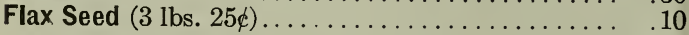

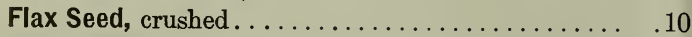

Hemp Seed $(3 \mathrm{lbs} .25 \phi) \ldots \ldots \ldots \ldots \ldots \ldots \ldots \ldots . .10$
Per lb.

Lettuce Seed, for birds...............\$0.20

Maw or Poppy Seed .................. .20

Millet, German or Golden. ................ . 05

Mustard Seed, white, for pickles............ . 15

Mustard Seed, black..................... .15

Osage Orange.......................... .40

Pumpkin Seed ......................... . .25

Rape Seed (3 lbs. 25ф) ................. .10

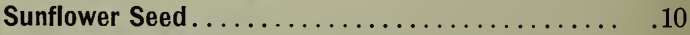

Water Melon Seed. . . . . . . . . .

Every One should keep a copy of all orders. Should there be any mistake made, it will be known just what it is and may save unpleasantness. 


\section{SEED POTATOES (Kartoffel, Ger.)}

Our Seed Potatoes are grown in the best northern districts and expressly for seed purposes. As prices are liable to vary, we shall be pleased to give quotations on application. Our supply has been secured from reliable growers, and include the following varieties.

Early Ohio-A seedling of the Early Rose, a week earlier, of excellent quality, tubers round and oblong in shape, flesh solid, cooks dry and mealy.

Early Rose-The leading variety for earliness and productiveness.

Early Six Weeks-Extra early, tubers oblong in shape, flesh solid, cooks dry and mealy

Irish Cobbler-This extra early variety is one of the very best. It matures in 7 to 8 weeks from planting. Tubers are of good size, nearly round, very heary yielder, clean smooth white skin, of excellent quality. A great favorite for first early.

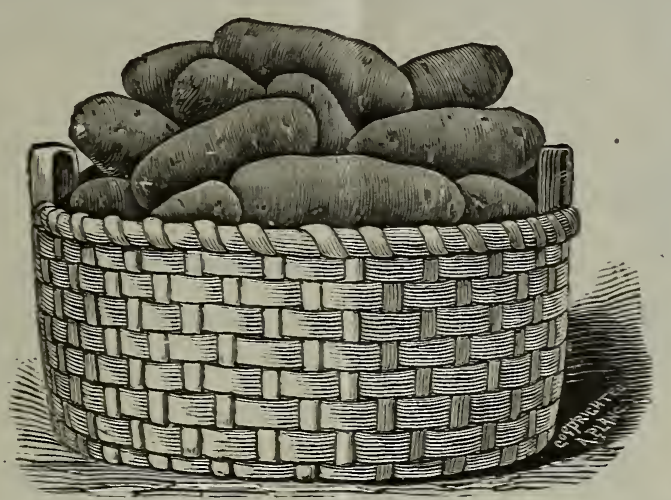

Bliss' Triumph-A round, reddish skinned variety, very arly and productive.

Carman No. 1-Uniform shape and immense yielder. Its cooking qualities are of a high order.

Burbank's-A white-skinned medium early variety, with few eyes, flesh fine grained and of excellent flavor, producing a large crop of marketable potatoes.

Chicago Market-Very popular, early, good quality and yields well

White Star-Medium early, a very large cropper, fine floury texture and delicious flavor, being unexcelled by any other variety.

Beauty of Hebron-Remarkably productive, tubers oblong and of extra size, skin and flesh white, table properties good, and keeps well.

White Elephant-Late, large, enormously productive and of excellent flavor, splendid keeping qualities.

\section{SEED SWEET POTATOES}

Yellow and Red Jersey, Red Bermuda and Southern Queen-Write for prices. Ready for shipment about April 1st.

\section{FERTILIZERS.}

\section{EXCELSIOR PLANT FOOD}

An Odorless preparation, combining in a concentrated and soluble form every element required in plants and flowers to produce vigorous growth and a profusion of flowers and fruit. Wonderful results are obtained, after one or two applications. It is immediately soluble in water, and available to plant life from the moment of application.

It assists in retaining moisture, will mature plants from two to three weeks earlier. "Where the plant food has been used Boll Weevil, cut worms, wire worm cannot live. Sold in powdered form and is used by dissolving in water. Small package, 10 cts.; by mail 15 cts.; postpaid.

\section{WIZARD BRAND PULVERIZED SHEEP MANURE}

This is a pure, natural manure and nutritious food for plants. Its effect is immediate. It is the best of all manure for mixing with the soil for green-house plants. It makes the richest, safest and quickest liquid manure. Nothing equals it for use on flower beds or for the vegetable garden. Especially valuable for lawns, contains all the constituents for promoting a quick, luxuriant growth, and a rich green color. No raking off required. No seeds of foul weeds in it. It is clean to handle. Absolutely safe to use in any quantity or in any manner.

Directions-For lawn, use at the rate of from 500 to 600 pounds per acre. For pot plants, mix one part of sheep manure to six parts of soil. For use in the vegetable garden, spread over the surface and dig in. Being soluble it readily makes a safe liquid manure-one pound to five gallons of water per day can be safely used. 10 cts. lb.; 25 cts. 5 lbs.; 50 cts. 15 lbs.; $\$ 1.0050$ lbs.; $\$ 1.75$ per $100 \mathrm{lbs}$.

Ashes-Hard Wood. Drive away insects and improve the texture of the soil; indispensible for all crops requiring potash, very beneficial for garden and field crops, grass land and lawns. Apply 1 to 2 tons per acre. $100 \mathrm{lbs}$. $\$ 1.35$; barrels, about 200 lbs., $\$ 2.00 ; 10$ barrels, $\$ 17.50$.

Pure Bone Meal-This finely pulverized ground bone is excellent for rose culture and lawns. It decomposes rapidly, and is more quickly effective than the coarser grade. It is excellent for mixing with soil for potting. $25 \mathrm{cts} .5 \mathrm{lbs}$; 40 cts. 10 lbs.; $\$ 1.00$, 35 lbs.; $\$ 1.25$, 50 lbs.; $\$ 2.50$ per bag of $125 \mathrm{lbs}$.

Bone Phosphate-For all grain crops, and especially good for spring crops and vegetables owing to its ammonia and potash. This grade is best adapted for wheat seeded on corn land, also for grass following wheat. 25 cts., $5 \mathrm{lbs}$; $\$ 1.75,100 \mathrm{lbs}$; $\$ 2.00,125 \mathrm{lb}$. bag; $\$ 13.00, \frac{1}{2}$ ton; $\$ 2$ J.00 ton.

Land Plaster-Is adapted to a great variety of uses, and sales are largely increasing as its value becomes better known. If applied as a top-dressing for grass and clover crops in the spring it greatly increases the growth and yield of same, in fact, its use is almost certain to insure a good stand of clover. If it is sprinkled in stables, poultry houses and on manure piles, it will prevent ammonia from vaporizing, thereby greatly increasing the value of farm manure. On account of its economical usefulness and effectiveness it should be liberally used on every farm. $\$ 1.40,200$ pound bag; $600 \mathrm{lbs}$. or more, 60 cts. per $100 \mathrm{lbs}$.

\section{MOSS}

Sphagumn-For packing and growing orchids, etc., 10 cts. lb.; $\$ 1.50$ bale.

Green, Sheet-40 cts. bale.

A FEW HINTS ON ALFALFA. The presence of lime in some form, either in the soil or subsoil, seems to be essential. If it is known there is no lime in the soil, lime should be applied as a top dressing when the land is being plowed preparatory to sowing the seed. GOOD DRAINAGE IS NECESSARY, for an excess of surface water soon rots out the roots. 


\section{SELECTED FLOWER SEEDS.}

We take pleasure in presenting to you our revised Flower Seed List, embracing only the best and most popular varieties. Our Flower Seed trade has increased very rapidly the last few years, which is very gratifying to us, as it speaks well for the quality of the seed we send out. Look it over carefully and add at least one or two packets to your vegetable seed order. It will pay you well. We do not sell old seeds, neither do we mix old seeds with new-every seed is new, fresh and clean. Everything is arranged in alphabetical order.

Annuals grow from the seed, bloom and perish in one season. Biennals generally bloom the first and second year and then die. Perennials bloom the second year and every year thereafter, some perishing after three or four years, others continue indefinitely. Some few Perennials, if started early, bloom the first year.

Full Cultural Directions on all Flower Seed Packets

\section{ALL FLOWER SEED SENT FREE BY MAIL ON RECEIPT OF PRICE}

Order by number, and thus avoid writing the name in full.

7 Five cent Packets for 25 cents.

\section{Special Offer on Seeds in Packets Only}

15 Five cent Packets for 50 cents.

40 Five cent Packets for $\$ 1.00$.

\section{ABUTILON.}

Half-hardy Perennial.

1. Finest Mixed.

\section{ABRONIA.}

Half-hardy Annual.

2. Umbrellata

\section{ACHILLEA}

3. Ptarmica fl. pl-(Double White Yarrow.)Hardy, perennial, and one of the best white blooming plants for the summer. They are hardly ever out of bloom, covering the two-feet high plants completely with their small, pure white flowers. Will bloom the first year if sown early.......

\section{ASPARAGUS}

4. Sprengeri-(Emerald Feather), an equally desirable plant either for the house, hanging baskets or vases for out-doors in summer and house or conservatory in winter. Readily raised from seed.............

ADLUMIA CIRRHOSIA, (Allegheny Vine) Hardy Annual.

5. Cirrhosia-Pale Pink................

\section{ACROCLINIUM}

Half-hardy Annual.

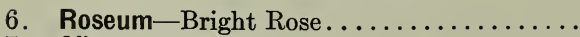

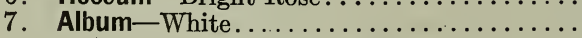

\section{AGERATUM \\ Half-hardy}

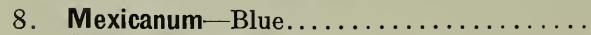

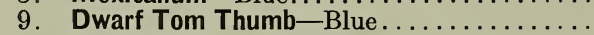

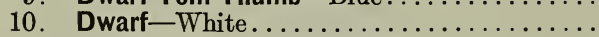

\section{ALYSSUM}

Hardy Annual

11. Sweet-White

12. Tom Thumb. .

\section{AMMOBIUM ALATUM.}

Hardy Annual

Pkt.

13. White

\section{AMARANTHUS}

Tender Annual

14. Tricolor-Joseph's Coat............. $5 \phi$

15. Salicifolius-(The Fountain Plant). Very

beautiful, one of the best............ $5 \&$

16. Caudatus-(Love Lies Bleeding)......... $5 \phi$

\section{AMPELOPSIS VEITCHII}

Hardy Perennial

17. Japanese Ivy................... $5 \phi$

\section{ANTIRRHINUM, (Snapdragon)}

Hardy Annual

$10 \phi$

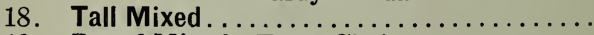

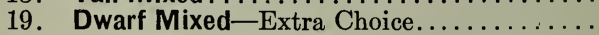

AQUILEGIA (Columbine)

Hardy Perennials

20. Mixed-Single.................. $5 \phi$

21. Mixed-Double................ $5 \varnothing$

\section{$10 \notin \quad$ ARISTOLOCHIA SIPHO}

22. Dutchman's Pipe

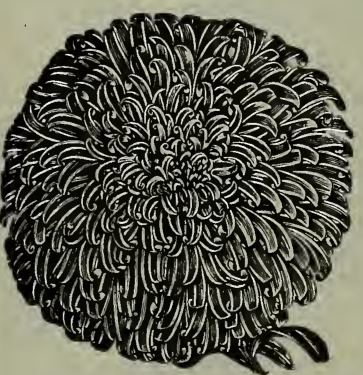

ASTERS

Annuals.

This splendid class of Plants is not only one of the most popular, but also one of the most effective, of our garden favorites.

23. Victoria-Mixed colors. 10 cts.pkt.

24. Co m e t-Fin es t mixed. 10 cts. pkt.

25. Trium ph-Deep scarlet, 15 cts. pkt.

26. Dwarf Chrysanthemums Flowered-Mixed.

27. Betteridge's Prize-Quilled. Mixed very double.................... $5 \phi$

28. Paeony Flowered Perfection-Finest Mixed. $10 \notin$

29. White-Exceedingly beautiful.......... $5 \&$

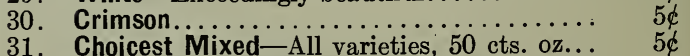

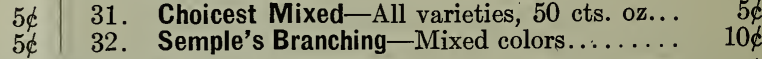


BALLOON VINE, (Cardiospermum)

Half-hardy Annual

33. Cardiosperum-White.............. Pkt.

\section{BALSAM, (Lady's Slipper)}

Annuals

34. White Perfection-Fine pure white, double flowers..........................

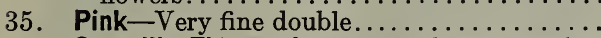

36. Camellia-Flowered-Very double and perfect

th in form, choice mixed................

37. Good Mixed-Double.................. BELLIS PERENNIS, (Double Daisy) Half-hardy Perennial

38. Double White

39. Double Finest Mixed.................. BROWALLIA

Half-hardy Annual

40. Fine Mixed..................

\section{BRYONOPSIS}

41. A beautiful annual climber of the gourd species, with ivy-like pale green foliage and showy fruit, first green striped white, turning when ripe to bright scarlet striped white. 10 feet.....................

\section{CACALIA, (Tassel Flower)}

Half-hardy Annual

42. Coccinea.........................

\section{CALCEOLARIA}

43. Hybrida Grandiflora-Tall mixed. The finest large flowering and most floriferous sorts, of the richest colors..............

CALENDULA, (Pot Marigold) Annuals

44. Meteor-Double, light orange striped......

45. Prince of Orange-Dark orange striped.....

\section{CAMPANULA OR CANTERBURY BELL}

Hardy Perennials

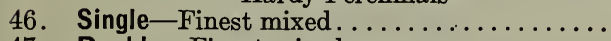

47. Double-Finest mixed..................

\section{MARGUERITE CARNATIONS} (Dianthus Caryophyllus)

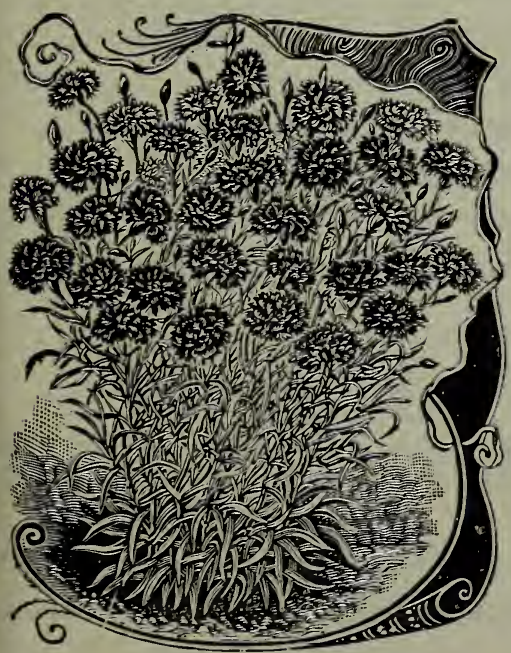

48. The popularity and usefulness of this variety has surpassed all expectations. They bloom in four months from time of sowing. If taken up and potted before frost they will con$t$ in $u$ e $t o$ bloom during the winter. Finest mixed 5 cts. pkt

49. Carnation Pinks-Double finest mixed. Saved from flowers of very fine quality only . . . . . . 10 cts. pkt.
50
CANARY BIRD FLOWER
(Tropaeolum Peregrinum)
Half-hardy Annuals

\section{CALLIOPSIS OR COREOPSIS}

This genus is amongst the most showy, freeflowering hardy annuals. 51. Lanceolata Grandiflora. Bright golden yellow flowers with broad fringed petals on long stems; excellent for cutting. Hardy. perennial. $10 \mathrm{cts}$. pkt. 52. Finest Mixed Varieties. 30 cts. oz.; 5 cts. pkt.

\section{CANNA}

Half-hardy Perennial 53. Finest Mixed-Producing different colored foliage 4 to $8 \mathrm{ft}$. $5 \notin$ pkt.

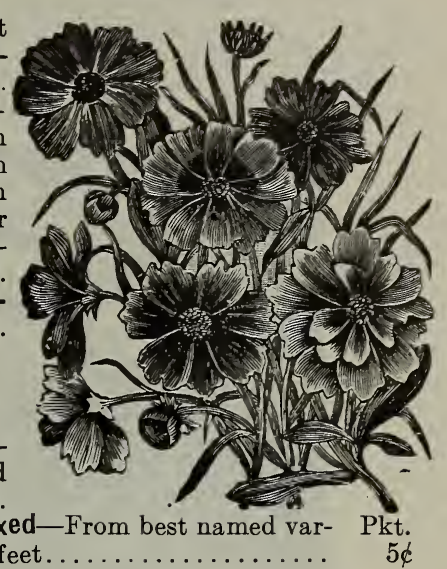

54. Crozy's Best Mixed-From best named var- Pkt.
ieties. 4 to 8 feet.................

55. Madam Crozy-Large flowers, vermillion, bordered with yellow, green foliage, very free flowering.

CANDYTUFT
Hardy Annuals

56. Fragrant-Pure white........20 cts. oz.; $5 \notin$

57. White Rocket-Fine white large truss..... $5 \dot{c}$

58. Crimson...................... 50 cts. oz.;

59. Fine Mixed......... 5 \&

\section{CENTRANTHUS}

\section{Hardy Annuals}

60. Very Pretty, free-flowering plants, effective in beds, ribbons or as an edging. Fine

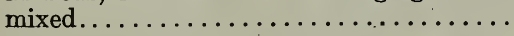

\section{CELOSIA, (Cockscomb)}

Half-hardy Annuals

61. Christata Nana-Choice mixture of newest dwarf crested varieties..............

62. Glasgow Prize-An improved Cockscomb, very large, dark crimson combs...........

63. Pyramidalis-A choice mixture of all the plumed and feathered sorts. .

64. Japonica-(Japanese). Combs are almost as delicately cut as ruffled lace............

\section{CENTAUREA}

Half-hardy Perennial

65. Candidissima-Large, smooth, silvery, cut

66. Gymnocarpa-A graceful, silvery fine-cut leaved variety ...............................

67. Cyanus-(Corn Flower). Hardy annual fine

\section{CHRYSANTHEMUM}

The hardy annuals are summer-flowering plants, good for pot culture, and quite distinct from the Indicum, which are perennial autumn-flowering varieties.

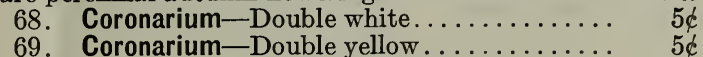

70. Eclipse-Pure golden yellow, with a bright purplish-scarlet ring, the disk being dark brown.

71. Indicum Majus-Choice mixed large flowering double varieties, half-hardy perennial 3 feet.

\section{$5 \phi$} $10 \notin$

$10 \dot{c}$

$5 \notin$

$5 £$

Finest Mixed............... 25 cts. oz.;

73. Frutescens-Paris Daisy or "Marguerite." The finest of the white "Daisies".......

74. Shasta Daisy. A grand, large-flowering Daisy, hardy, robust growth and produces larger and finer flowers each season as the plants increase in strength.
$5 \notin$

$10 \notin$

$5 \dot{c}$

$5 \notin$

$10 \frac{\varepsilon}{c}$

A BEAUTIFUL LAWN is the result of sowing under:proper conditions our Emerald Lawn-Seed. 


\section{CYCLAMEN}

Charming bulbous-rooted plants, with beautiful foliage and rich colored orchid-like fragrant flowers; universal favorites for winter and spring blooming. If seed is sown early they make flowering bulbs in one season. They require sandy loam. Half-hardy perennial. 6 inches.

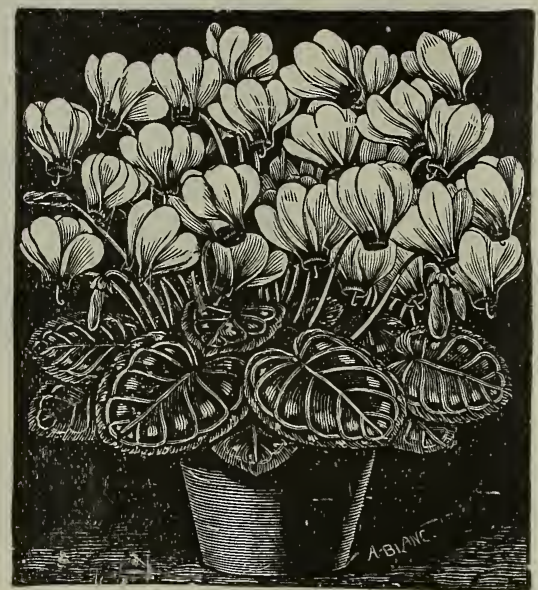

75. Cyclamen Persicum-Finest mixed ........

76. Cyclamen Persicum Giganteum-Finest mixed...

\section{CINERARIA}

Perennials

77. Hybrid Grandiflora-Prize, mixed, extra selected, unsurpassable in quality, and beau-

78. Maritima-(Dusty Miller). Large, silvery, deep cut foliage................ $5 \phi$

\section{CLARKIA}

79. Finest Mixed. . . . . . . . . . . . . .

\section{COBEA SCANDENS}

A well known climber of quick growth, producing beautiful large bell-shaped flowers.

80. Purple.

81. White...

$5 \notin$

$10 \varnothing$

\section{COLLINSIA}

Hardy Annual

82 Finest Mixed.............40 cts. oz.; . $5 \phi$

\section{CLEMATIS}

A well known and rapid growing, free-flowering, ornamental climber. Flowers three or four inches across, of charming shades of blue, white, purple, etc.

83. Finest Mixed................ $10 \notin$

\section{CYPRESS VINE}

A most popular climbing plant, with delicate fern-like foliage, half-hardy annual:

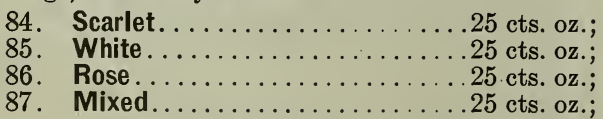

\section{DAHLIA}

Half-hardy Perennial

88. Double Finest Mixed.

89. Single Finest Mixed.

\section{COSMOS}

Easily raised from seed, and bloom the first season.

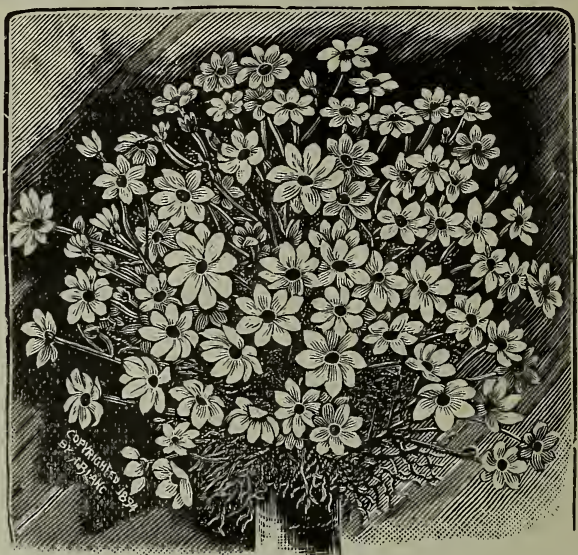

90. White Pearl.

Pkt.

91. Mixed ....................... 5

\section{DIANTHUS (Pinks)}

Hardy Biennials

92. Chinensis fl pl-(Chinese Pink). Finest double mixed ................ 5

93. Heddewigii, fl pl-Finest double mixed..... $5 \phi$

94. Heddewigii, Single - Finest Mixed........ $5 \phi$

95. Laciniatus, Single-Finest mixed, very beautiful, deeply fringed............... 56

96. Laciniatus, fl pl-Flowers very large and deeply fringed $\ldots \ldots \ldots \ldots \ldots \ldots \ldots \ldots \ldots \ldots$

DATURA, (Sweet Nightingale)

97. Flowers pure white, 9 inches long and 5 or 6 inches wide at the top................

\section{DIGITALIS, (Foxglove)}

Handsome border plants with a great variety of colors. Hardy biennial.

98. Finest Mixed . . . . . . . . . 50 cts..oz.; $5 \phi$

DELPHINIUM (Perennial Larkspur)

99. Delphinium Mixed............... 5

EDELWEISS, (Gnaphalium Leontopodium)

100. The famous and true "Edelweiss" of the Alps. The flowers are of a downy texture pure white and star-shaped...........

EUPHORBIA, (Mexican Fire Plant) Hardy Annual

101. Helerophylia...................

\section{ESCHSCHOLTZIA, (California Poppy)} Hardy Annual

102. California-Yellow..........25 cts. oz.; $5 \notin$ 103. Finest Mixed . . . . . . . . . $5 \ldots \ldots 20$ cts.

\section{FREESIA}

Flowers pure white with yellow throat, and exquisitely fragrant.

104. Freesia Refracta Alba .............. $10 \notin$

\section{GAILLARDIA}

Hardy Annual

105. Grandiflora-Fine Mixed ........... 5

106. Lorenziana-Beautiful double flowers, fine for bouquets. . . . . . . . . . . . . . 


\section{GOMPHRENA}

107.

Bachelor's Button.

Pkt.

\section{GERANIUM (Pelargonium)}

Started early will flower the first year from seed.

108. Large Flowered-Finest mixture........

$$
\text { GILIA }
$$

Hardy Annual

109. Mixed

\section{GOURDS, Ornamental}

Tender Annuals

110. Hercules Club-Curious large variety .......

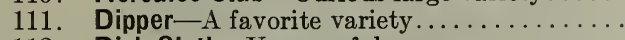

112. Dish Cloth-Very useful.

113. Nest Egg-Resembling an egg in color, shape

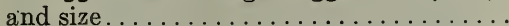

114. Orange-Fruit resembles an orange.......

115. Bottle-Useful and ornamental ............

116. Fine Mixed.............. 25 cts. oz.;

\section{GODETIA}

Hardy Annual

117. Lady Albemarle-Intense carmine crimson,

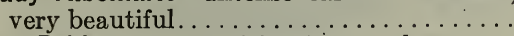

118. The Bride - White, with crimson edge.....

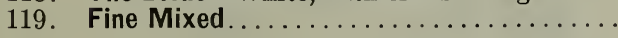

\section{HELIOTROPE}

Half-hardy Perennial

120. Finest Varieties Mixed.

\section{HELICHRYSUM (Everlasting) Hardy Annual}

121. Finest Mixed

\section{HOLLYHOCK (Althea) \\ Hardy Perennial}

122. Double White-Flowers pure white, extra for

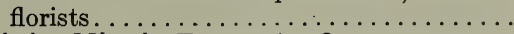

123. Choice Mixed-From prize flowers . . . . . .

124. Fine Mixed.............. 75 cts. oz.;

\section{HONESTY}

Hardy Biennial

125. Lunaria Biennis

\section{HUMULUS JAPONICUS}

126. This new Japanese variety of Hop is a splendid annual climber

\section{HYACINTH BEAN}

A rapid growing plant, flowering freely in clusters, for covering arbors, trellises, etc.

127. Dolichos Mixed-10 feet......15 cts. oz.;

\section{ICE PLANT (Mesembryanthemum)}

Half-hardy Annual

128. Crystallinum.

\section{JOB'S TEARS}

129. Coix Lachryma-Broad, corn-like leaves, and hard, shining, pearly seeds resembling tears; $2 \mathrm{ft} \ldots \ldots \ldots \ldots \ldots \ldots \ldots \ldots \ldots \ldots$

KOCHIA (Summar Cypress, or Burning Bush)

130. Tricophylla-A pretty annual, forming a close cypress-like bush about 3 feet high. Admirable for forming hedges, which by approach of autumn turn to a deep red.....

$10 \notin$

$5 c$
$5 c$
$5 c$
$5 \phi$
$5 c$
$5 c$
$5 c$

$5 \dot{c}$

$5 \notin$

$10 d$
$10 d$
$5 c$

$5 c$

Hardy Perennial

Pkt.

131. Linaria Cymbalaria-Lavender and purple.. $10 \varnothing$

\section{LANTANA}

132. Hybrida Mixed...........80 cts. oz.; $5 \phi$

$5 £$

13

133. Dwarf Rocket. ............50 cts. oz.; $5 \phi$

LARKSPUR (Annual Delphinium)

Hardy Annuals

134. Tall Rocket................... $5 \dot{k}$

\section{LOBELIA}

Half-hardy Annual

135. Crystal Palace-Intense blue flowers $\frac{1}{2}$ foot. $5 \varnothing$

\section{LUPINS}

136. Mixed Annual Varieties.........30 cts. oz.; $5 \varnothing$

\section{LICHNIS}

Hardy Perennials

137. Chalcedonia-Fine border plant, scarlet.... $5 \notin$

MARIGOLD (Tagetes)

Half-hardy Annuals

138. African Lemon-Large, double lemon flowers.

139. African Orange 5 ckt. double orange flowers.

140. French Dwarf Mixed.

141. African El Dorado-The colors run through all shades of yellow, from light primrose to the deepest orange. 40 cts. oz. 5 c pkt.

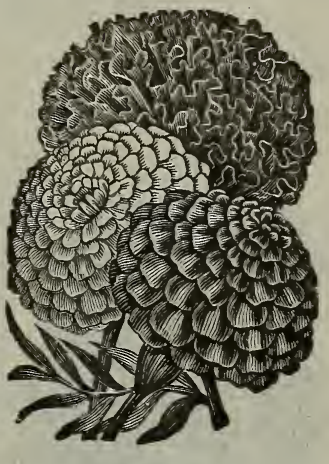

MIGNONETTE

(Reseda Odorata)

$5 c$

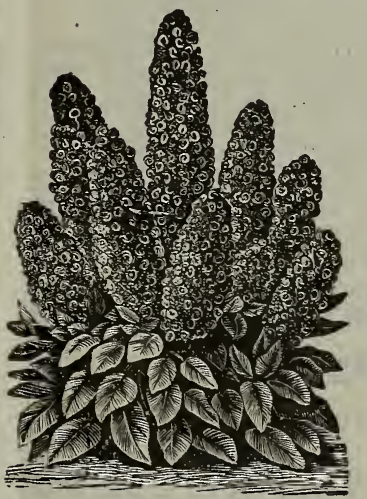

142. Miles' Hybrid SpiralProfuse bloomer, very fragrant. 25c oz;5 $\dot{k p k t}$

143. Golden Queen-A very beautiful new variety, flowers bright, golden in color and very effective. $5 \xi$ pkt.

144. Sweet-15£ oz.; $5 \notin$ pkt.

145. Machet-The finest variety for pot culture sweetscentedred flowers. 25ć oz.; $5 \dot{c}$ pkt.

\section{MAURANDIA}

146. Wharming Half-Hardy Perennial Climbers

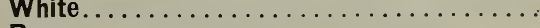

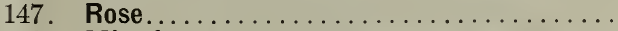

148. Mixed................

MIRABILIS (Four O'Clocks, Marvel of Peru)

149. Finest Mixed............. 15 cts. oz.; $5 \varnothing$

MIMULUS:MUSCHATUS (Musk Plant)

150. Fine for hanging baskets, etc. Small yellow flowers, fragrant foliage. .

We issue in September a Catalogue of Flowering Bulbs for Autumn planting, which we will be glad to mail on request. 
MIMOSA (Sensitive Plant)

Half-hard Annuals. $1 \frac{1}{2} \mathrm{ft}$.

151. Pudica-Sensitive plant.......80 cts. oz.; $5 \notin$

\section{MOMORDICA}

Half-hardy Annuals

152. Balsamina-Balsam apple....60 cts. oz.; $5 \phi$

153. Charantia-Balsam pear......6. 60 cts. oz.; $5 \notin$

\section{MOONFLOWER}

154. Flowers are pure white, large and fragrant.

MORNING GLORY, TALL (Convolvulus Major) Half-hardy Annual

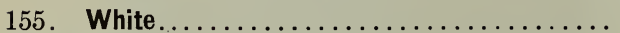

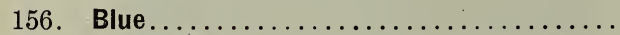

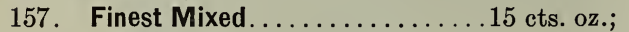

158. Japanese . . . . . . . . . . . . . . . .

159. Dwarf Mixed.............25 cts. oz.;

MYOSOTIS (Forget-me-not)

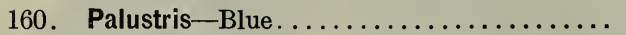

NASTURTIUM, DWARF

(Tropaeolum Nanum)

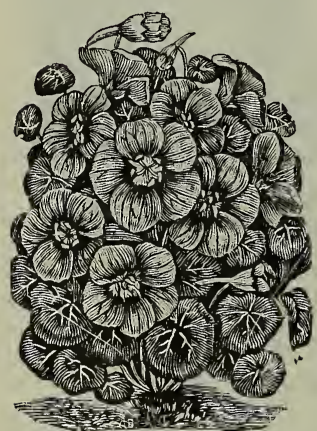

Half-hardy Annuals

161. Beauty-Orange and vermillion. $15 \mathrm{cts} . \mathrm{oz}$; 5 cts. pkt.

162. Crystal Palace Gem.Sulphur spotted with maroon. 15 cts. oz.; 5 cts. pkt.

163. Pearl-Nearly white. 15 cts. oz.; 5 cts. pkt.

164. King Theodore-Deep maroon. 15 cts. oz.; 5 cts. pkt.

165. King of Tom ThumbsScarlet, bluish green foliage. 15 cts. oz.; 5 cts. pkt.

166. Chameleon-This interesting variety produces flowers of different colors on the

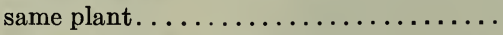

167. Empress of India-Splendid variety, brilliant crimson with dark foliage...........

168. Finest Mixed............ 10 cts. oz.;

\section{NASTURTIUM, TALL}

Hardy Annuals

169. Coccineum-Scarlet.........15 cts. oz.;

170. Orange-Beautiful dark orange. .15 cts. oz.;

171. Spotted-Very pretty.........15 cts. oz.;

172. Purple Violet............... 15 cts. oz.;

173. Mixed................. 10 cts. oz.;

\section{LOBB'S CLIMBING NASTURTIUMS}

Both foliage and flowers of this class are somewhat smaller than the Tall varieties, but the splendid profusion of bioom and the intensely brilliant colors of the flowers render them of the greatest value. 12 to 15 feet.

174. Lobb's Finest Mixed.

$5 \varnothing$

\section{NICOTIANA}

Half-hardy Annuals

Pkt.

175. Affinis - White, very fragrant......... $5 \phi$

OENOTHERA (Evening Primrose)

176. Biennis-True evening primrose, a beautiful and free flowering plant, with long spikes of bright yellow flowers..............

$5 \phi$

\section{OXALIS}

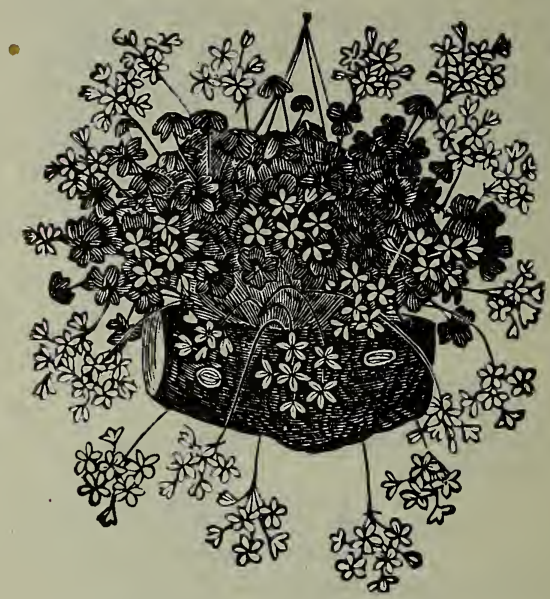

A splendid class of plants, with brilliant-colored flowers and dark foliage, suitable for borders, green-house decoration, rock-work or baskets. Half-hardy perennial.

177. Finest Mixed................ $5 \varnothing$

\section{PASSIFLORA (Passion Flower)}

178. Coerulea-Blue and white flowers of remarkable beauty............... $10 \notin$

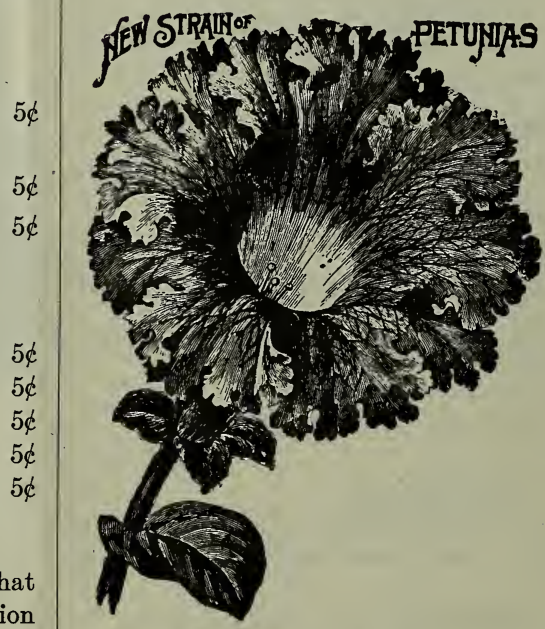

\section{PETUNIA}

These wellknown and much admired plants are of the easiest culture, and produce a profusion of flowers during the season; in flower July to October, half hardy annuals.

179. Nyctaginiflora-White fragrant. 5 cts. pkt.

180. Fine Mixed-5£ Pkt.

181. H y b rid a GrandifloraMagnificent flowers of extra largesize, beautifully fringed and varigated,

extra choice 15 cts. pkt.

182. Double Fringed-A most beautiful variety. . - $25 \phi$ 


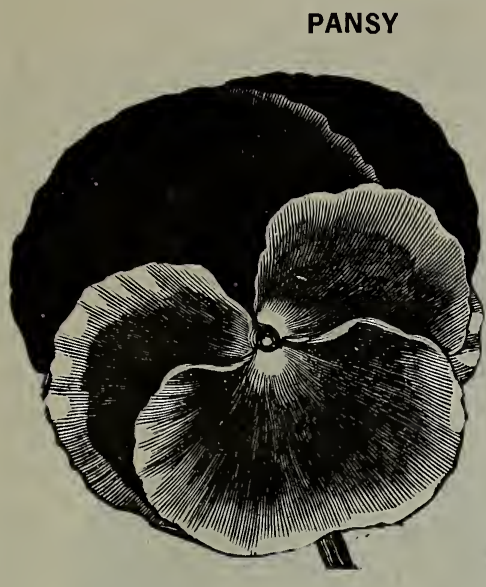

This lovely flower, a favorite with every one, is too well known to need any description. It will flower in the middle of summer if planted where it is somewhat shaded from the hot sun, and especially if furnished with a good supply of water, but in almost any situation will give fine flowers in spring.

\section{PANSY}

Hardy Perennial

183. Bugnot, Cassier and Odier Strains-Superb mixture of unsurpassed quality..........

184. Cassier's Giant-The flowers of immense size, of good substance and fine form, while the plants are of neat, compact growth..

185. Improved Giant Trimardeau-Greatly improved in the enormous size of flowers, fine form and increased varieties of colors

186. Odier or Blotched-Superb, large-eyed flowers of very good shape and beautifully blotched with rich and varied colors.....

187. J. C. McCullough's Mixture-Flowers very large and beautifully marked, plants neat

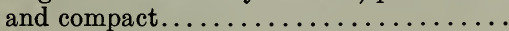

188. King of the Blacks-Almost coal black, extra

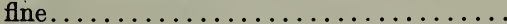

189. Snow Queen-Delicate, satiny white.......

190. Yellow Giant-Pure yellow. .............

191. Choice Large Flowering-Mixed, splendid

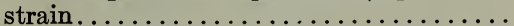

192. Fine Mixed-Large flowering . ...75 cts. oz.;

Pkt.

$15 \phi$

$15 \varnothing$

$10 \phi$

$10 \notin$

$20 \notin$

$5 \notin$

$5 \phi$

$5 \dot{c}$

$10 \notin$

$5 \phi$

\section{POPPY (Papaver)}

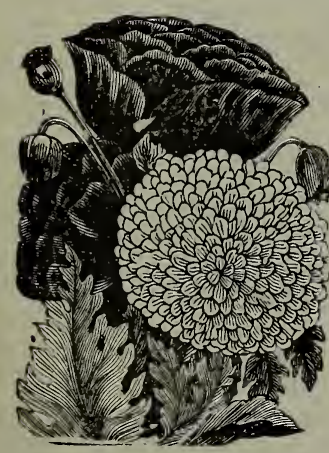

A tribe of remarkable freeflowering plants, producing a rich and effective display in large, mixed borders, grow freely in any common soil, hardy annuals, 2 feet.

\section{Carnation Flowered} Double mixed. 20 cts. oz.......

194. Paeony FloweredDouble mixed. 20 cts. oz.......

195. Shirley's-Fancy mixed...........

196. Mikado-Flowers pure white at the back, while the fringed edges are of brilliant scarlet. . . . ...............

197. Umbrosum-Flowers of glowing vermillion, with a deep black spot on each petal, single

198. Iceland-Mixed, hardy perennial .........

199. Orientale-Superb scarlet flowers, often 6 inches across, hardy perennial .........
$5 \phi$

PORTULACA (Mexican Rose)

Hardy Annuals

Pkt.

200. Double-Mixed.................. $10 \notin$

201. Single-Mixed ............

\section{PHLOX DRUMMONDII}

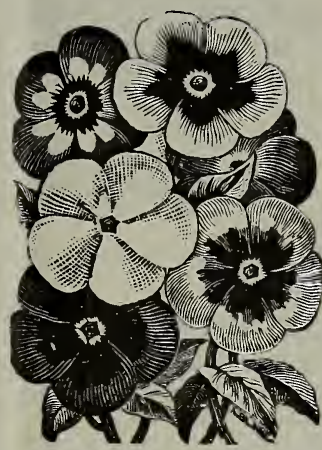

For brilliant effect and continous blooming in the flower garden, it is hardly possible to overestimate the Phlox Drummondii, as a plant of simple culture and accomodating habit it is not excelled by any annual in cultivation, half hardy annuals, $1 \frac{1}{2}$ to $2 \mathrm{ft}$. $\quad$ 醩 202. Alba-Pure white. $10 \notin$

203. Alba OculataWhite with crimson eye..........

$10 \phi$

204. Splendens-Large bright scarlet, extra.......... $10 \notin$

205. Fimbriata..................... $10 \notin$

206. Star of Quedlinburg............... 10

207. Fine Mixed.............50 cts. oz.; $5 \phi$

208. Grandiflora-Finest mixed. An improved variety, with unusually large flowers of great substance............... $10 \notin$

209. Perennial-Fine mixed............. $10 \varnothing$

\section{PRIMULA (Chinese Primrose)}

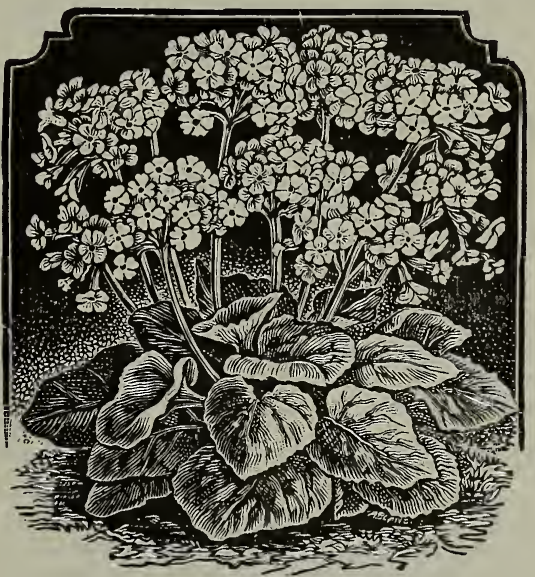

210. Sinensis-Double mixed.

$15 \phi$

211. Sinensis-Mixed................ 15

212. Primula Obconica-Almost ever blooming, flowers white, tinged with lilac.........

\section{PYRETHRUM (Feverfew)} Annual

213. Double Pure White- $1 \frac{1}{2} \mathrm{ft} . \ldots \ldots \ldots \ldots \ldots .5 \%$

214. Golden Feather-Golden Foliage, one of the best bedding plants, 1 foot............

215. Roseum-Persian insect powder plant halfhardy perennial.................. 


\section{RHODANTHE}

\section{RICINUS (Castor Oil Bean)}

Half-hardy Annuals

217. Finest Mixed............ 15 cts. oz.;

218. Borboniensis Arboreus-A very large and handsome variety, 15 feet. . . 20 cts. oz.;

\section{RUDBECKIA (Cone Flower)}

219. Bicolor Superba-An effective annual, and useful for cutting. It grows about two feet high, forming a many-branched dense bush, the flowers borne on long stems and in great profusion.................

\section{SALPIGLOSSIS}

Half-hardy Annual

220. Large Flowered-All colors, mixed.

\section{SALVIA, OR SCARLET SȦGE}

Gorgeous effects can be produced by massing on the lawn or in the garden, or planted in rows along a sunny drive. A perennial, but blooms the first season from seed.

221. Clara Bedman, or Bonfire--The finest Salvia ever introduced, and by far the best for bedding and massing on the lawn........ 222. Spiendens-Scarlet.

223. Coccinea-2 ft. Annual scarlet sage.......

\section{SCARLET RUNNERS}

224. A beautiful ornamental climber, producing dazzling scarlet flowers and beans, it grows to a height of 10 feet................

\section{SCABIOSA}

225. Tall-Finest mixed. .

226. Dwarf-Finest mixed.

\section{SCHIZANTHUS (Butterfly Flower) . Half hardy Annual}

227. Mixed Varieties.

\section{SILENE (Catch Fly) Hardy Annual}

All Colors-Mixed..................

\section{SMILAX}

A beautiful climbing plant, with delicate graceful foliage, extensively used in bouquets, baskets and interior decorations.

229. Myrsiphyllum .................

\section{STOCKS, GILLIFLOWER (German Ten Weeks)}

All the varieties are desirable as pot-plants as well as in the open garden. They are greatly prized for cut-flowers, on account of their fragrance and diversity of colors. Half hardy annuals.

Large Flowering-Dark blood red . . . . . . . .

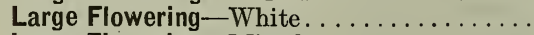

Large Flowering-Mixed . . . . . . . . . . . .

Snowflake.

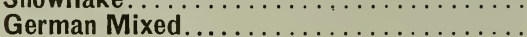

\section{SUNFLOWER (Helianthus)}

Well-known, tall growing plants, with large brilliant yellow flowers; they are very effective in proper situations, in large shrubbery borders; hardy annuals.

235. Minature - Golden yellow flowers. . . . . . . .

236. Californicus-Orange, large, double extra, 7 feet.

237. Globosus Fistulosus-Large, yellow, finest of all double, 7 feet..........20 cts. oz.;

Pkt.

$5 \phi$

Beautiful free flowering climbing plants, producing vast numbers of fragrant flowers, valuable for covering unsightly places, rough fences and trellis work. If the flowers are picked freely, they will be produced long in profusion, and $5 \notin \quad$ of good size, hardy annuals.

\section{$5 \dot{c}$}

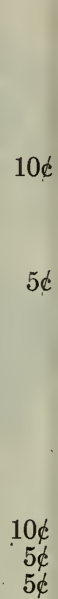

$10 \phi$
$5 \phi$
$5 \phi$

$5 \phi$

$5 \notin$

$5 \phi$

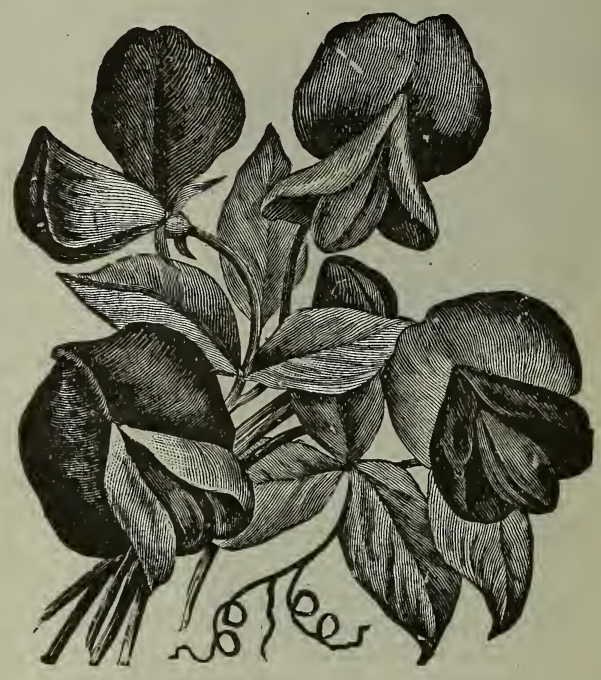

\section{Giant Orchid-Flowering Sweet Peas}

\section{COUNTESS SPENCER HYBRIDS}

The largest in size of all Sweet Peas, this distinct type is a wonderful new departure and embraces the most exquisite shades of pink, orange, salmon and rose. These new seedlings can only be appropriately described as Truly three or four large flowers and during cold weather, when Sweet Peas are at their best, as many as six flowers on a single stem.

238. Apple Blossom Spencer-An exact reproduction of Apple Blossom and having the splendid wavy blossoms of the Spencer type.

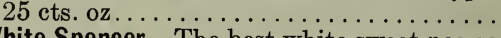

239. White Spencer-The best white sweet pea so far offered. It has a very large fluted and crinkly standard. Flowers borne three and four on long stems..........25 cts. oz.;

240. Asta Ohn Spencer-A splendid lavender Spencer. Enormous frilled flowers upon stiff stems................. 25 cts. oz.;

241. Florence Morse-A dark pink flowered Spencer. ..................... 25 cts. oz.;

242. Geo. Herbert Spencer-A new Spencer, bright rosy carmine in color. . .25 cts. oz.;

243. King Edward VII Spencer-The grand carmine, scarlet flowered Spencer. Flowers are deeply frilled..........25 cts. oz.; $10 \notin$

244. Spencer Type-Mixed Colors. 5 cts. pkt.; 20 cts. oz.; 75 cts. $\frac{1}{4}$ lb.; $\$ 2.00 \mathrm{lb}$.

\section{Standard Named Varieties}

Pkt.

245. Admiration-A most delicate pinkish laven-

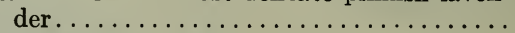

246. Agnes Johnson-Deep pink, shaded cream...

247. Aurora - Salmon on white.............

248. Blanche Burpee-Pure white, very large....

$5 \varnothing \quad 249$. Blanche Ferry-Pink and white; extra early. 250. Countess of Lathom-Creamy pink ........ 251. Countess of Codagan-New bright violet, wings sky blue ..................

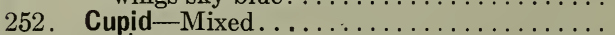
Gigantic "Orchid-flowered." Stems extra long, having 
SWEET PEAS (Lathyrous Odoratus) Standard Named Varieties

253. Dainty-New, white with pink edge, unique

254. Dorothy Eckford-This is the best of all the best white Sweet Peas. . . . . . . . . . .

255. Emily Henderson-Purest white, early .....

256. Golden Rose-New, clear primrose yellow, flushed with rosy pink..............

257. Hon. F. Bouverie-New, standard coral pink, wings slightly lighter................

258. Hon. Mrs. E. Kenyon-Large primrose.....

259. Janet Scott-New, deep pink. . . . . . . .

260. Jeanie Gordon-New, standards bright rose, shaded cream....................

261. King Edward VII-This is the very best of the dark, rich, red sorts..............

262. Lady Grisel Hamilton-Lavender, the best. .

263. Lottie Eckford-White, edged with blue....

264. Lord Roseberry-New, rose-carmine, self

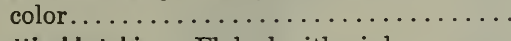

265. Lottie Hutchins-Flaked with pink on cream

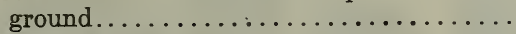

266. Mrs. Walter Wright-New, rose purple....

267. Miss Wilmott-A rich, deep orange pink, very large......................

268. Navy Blue-Deep violet blue..........

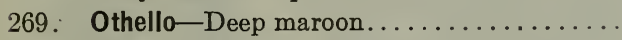

270. Prima Donna-Soft rose pink...........

271. Prince of Wales-Fine bright rose, self-col-

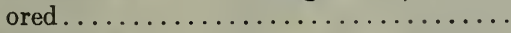

272. Prince Edward or York-New, scarlet and

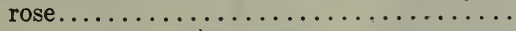

273. Royal Rose-Bright pink............

274. Stella Morse-Primrose, flushed with pink. .

Price-Any of the above, 15 cts. oz.; 50 cts. $\frac{1}{1} \mathrm{lb}$.; $\$ 1.50 \mathrm{lb}$. Any 6 pkts. 20 cts.; any 15 pkts. 50 cts.

275. J. C. McC's-Named varieties, finest mixed, 15 cts. oz.; 50 cts. $\frac{1}{4}$ lb.; $\$ 1.50 \mathrm{lb} \ldots \ldots \ldots$.

276. Fine Mixed-10 cts. oz.; 35 cts. $\frac{1}{4}$ lb.; $\$ 1.25 \mathrm{lb}$

\section{LATHYRUS (Everlasting Pea)}

Showy, free-flowering hardy perennial climbers for covering old stumps, fences, etc.; continually in bloom, fine for cutting.

277. Fine Mixed

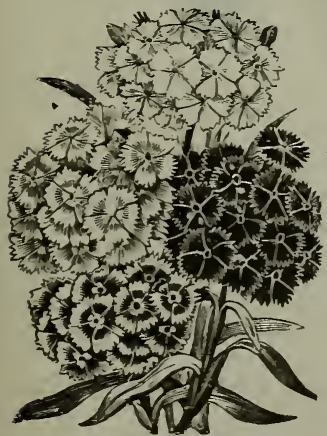

\section{SWEET WILLIAM (Dianthus Barbatus)}

A beautiful class of hardy perennials, with flowers of rich and varied colors.

278. Fine Single Mixed-

50 cts. oz........ 5 6

279. Finest Double Mixed $\$ 1.25 \mathrm{oz} \ldots \ldots \ldots$....

\section{THUNBERGIA,}

(Black-eyed Susan)

280. Alata Alba-White, with dark eye.........

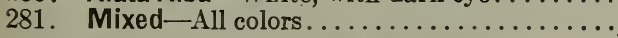

\section{TORENIA}

282. Bailloni-Yellow, with brownish red throat 10 c 283. Fournieri-Velvety-blue............. $10 \notin$

\section{VERBENA}

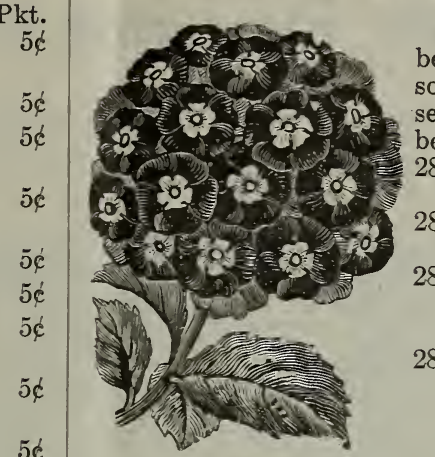

288. Fine Mixed
Well-known plants of great beauty and variety. When sown early will flower the first season, in flower May to October, half hardy perennials.

284. Defiance-Beau- Pkt. tiful, deep scarlet $10 \notin$ 285. Italian StripedMixed.

286. CandidissimaThe best pure white.

287. Choice Mixed.Saved only from the most beautiful named flowers

10 é

5 ć

289. Fine Mixed.

VINCA (Madagascar Periwinkle)

VIOLET (Viola Odorata) Hardy Perennials

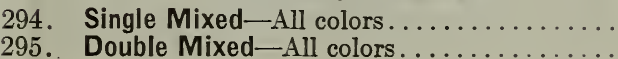

290. Odorata-Sweet Violet, blue........... 10

291. The Czar-Light Violet, very fragrant....... 10

\section{VIRGINIAN STOCK (Cheiranthus Maritimus) Hardy Annuals}

292. Red and White.

\section{VISCARIA (Rose of Heaven) Annual}

293. Finest Mixed. . . . . . . . . . . . . . .

\section{WALLFLOWER}

Half-hardy Perennials

\section{WHITLAVIA}

Hardy Annual

296. Mixed Varieties.

\section{XERANTHUMUM}

Hardy Annual

297 Double Sorts-Finest mixed..

\section{ZINNIA}

Hardy Annuals

298. Double Purple

299. Double Scarlet.

300. Double White

301. Double Mixed ....

302. Dwarf Double Mixed.........................

\section{WILD CUCUMBER VINE}

303. The quickest climber for arbors, trellis, fences, etc., known. . .

\section{"WILD GARDEN" FLOWER SEEDS}

304. All lovers of flowers who are fond of novelties in the way of flower gardens, and cannot give much time in the way of cultivation, will find this mixture the desirable thing if sown en masse, as it will produce a continuous bloom of flowers of every hue, and you will have a mass of floriferous splendor that will last all summer; this mixture is composed of the most free and showy annuals, suitable for a wild garden of flowers. 25 cts. oz.; 15 cts. $\frac{1}{2} \mathrm{oz}$

THE FAMILY GARDEN CAN BE BEAUTIFIED by planting a few of the annual flowers offered in this catalogue. A row of Sweet Peas, a bed of Nasturtiums, etc., will also furnish an abundance of flowers for decorating the table. 


\section{Summer Flowering Bulbs and Roots.}

The summer flowering bulbs and roots are inexpensive, very easily grown, require scarcely any care and produce some of the most showy and beautiful of all summer and autumn flowers. Before hard frost the bulbs must be taken up and stored away in some place secure from frost until spring.

At the prices quoted on single bulbs or by the dozen, we send either by express or mail prepaid, by the 100 or 1000 at purchaser's expense. No less than 6 will be sent at the dozen, nor less than 50 at the 100 rate.

\section{AMARYLLIS}

Formosissima-Velvety crimson, a desir-

able border plant........... $15 \phi$

Each. Doz.

Rosea-Rose pink............. $5 \phi$

Treatea-White, fairy lily of the south... $4 \phi$

\section{BEGONIAS (Tuberous-Rooted)}

The Tuberous-Rooted Begonias are among the most beautiful of our flowering bulbs. They will bloom throughout the summer, requiring no more care than a geranium. The colors range from the most delicate shades of yellow and salmon to crimson, white and scarlet. The tubers may be preserved dry in winter, by packing in charcoal dust.

Single, Scarlet, Crimson, Pink, White and

Yellow. In separate colors........ 10

Each.

Doz.

Single Varieties-Mixed colors......... $8 \phi$

$\$ 0.75$

Double Varieties-Rose, scarlet, white and

yellow.................. 15

Double Varieties-Mixed colors........ $10 \phi$

1.00

\section{CALADIUM ESCULENTUM}

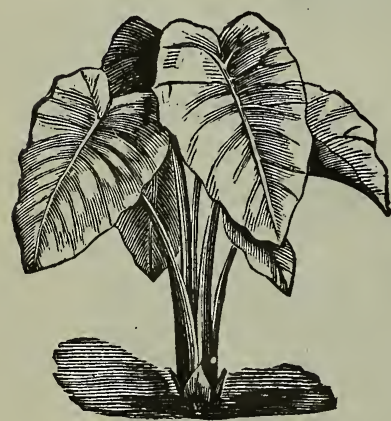

One of the most striking of the ornamental foliage plants, either for pot or lawn planting. It will grow in any good garden soil; it is of easy culture; a full sized plant being 4 to 5 feet in height, with immense leaves.

Caladium

Each. Doz.

Small size......................10\& $\$ 1.00$

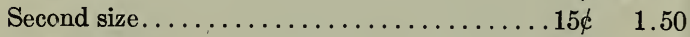

Large size....................... $25 \notin \quad 2.50$

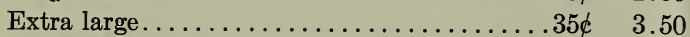

Monsters....................50 J 5.00

\section{CANNAS}

Canna tubers should not be put into the ground until the soil has become warm. They commence blooming in June and continue until late in September. Every shoot bears a flower, and these shoots are being constantly produced throughout the blooming season.

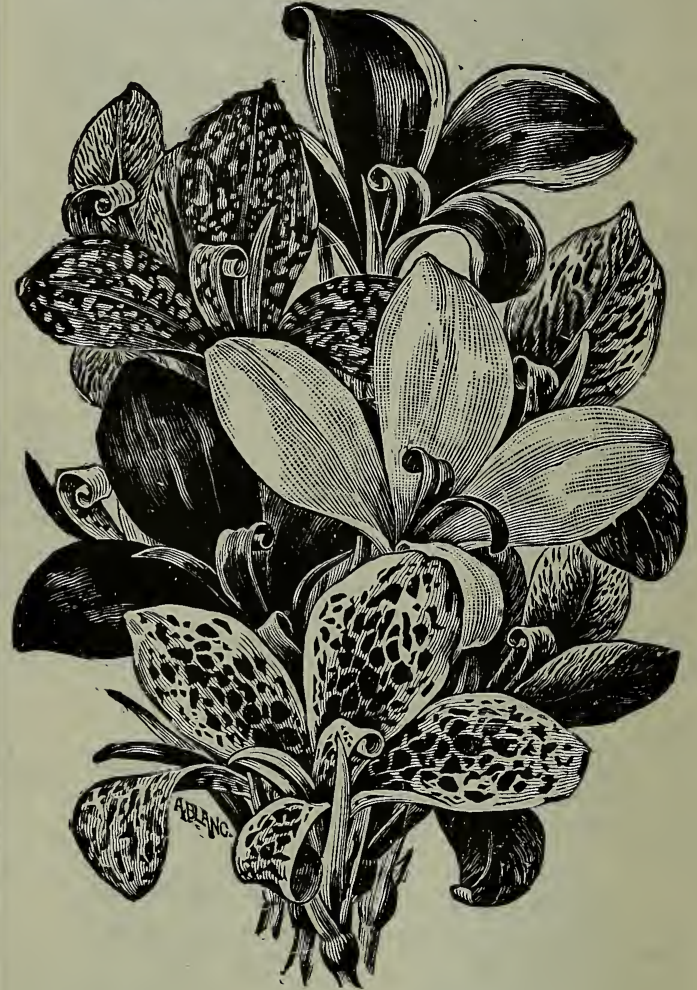

\section{DWARF FRENCH CANNAS}

Alphonse Bouvier -6 feet. Foliage green, crimson flowers. Alsace -4 feet. Green leaves, lemon changing to white. Chas. Henderson-3 feet. Fine green foliage, crimson. Flamingo-3 feet. Glowing crimson. Appropriately named. Florence Vaughan -4 feet. Yellow, thickly spotted with red. A famous Canna, thoroughly tried and hard to beat.

Madam Crozy -4 feet. Crimson scarlet, bordered with golden yellow.

King Humbert $-4 \mathrm{ft}$. Magnificent giant flowers of pure orange-scarlet, produced in great trusses, setting off to great advantage the handsome leathery bronze foliage.

Egandale-4 feet. Bronzy foliage and soft currant-red flowers held well above the leaves, the best of its type.

Queen Charlotte-3 feet. Scarlet bordered with gold.

Any of the above varieties, dormant roots, $10 \mathrm{cts}$. each; 75 cts. doz.

Note.-We do not send BULBS of any kind by mail until all danger of their freezing is passed, usually about April 1st. 


\section{ORCHID FLOWERED CANNAS}

Austria-6 feet. Large flowers and foliage. Flowers pure canary yellow, spotted with red spots.

Burbank -5 feet. Individual flowers 7 inches across. Canary yellow, with small crimson spots.

Italia-5 feet. Flowers red, bordered with golden yellow.

Any of the above varieties, dormant roots, $10 \mathrm{cts}$. each; $75 \mathrm{cts}$. doz.

Mixed Dwarf Cannas-6 cts. each; 60 cts. doz.

Mixed Tall Cannas-10 cts. each; $: 75$ cts. doz.

\section{DAHLIAS}

The Dahlia is one of the showiest of our autumn flowers. Commencing to flower in August they are in a perfect blaze of bloom until stopped by frost in late autumn. They delight in a deep, rich soil; should be planted $3 \frac{1}{2}$ to 4 feet apart, and be tied to heavy stakes to prevent strong winds from breaking them down.

\section{CACTUS DAHLIAS}

Characterized by long, narrow, pointed, tubular and twisted petals of graded lengths, giving the layered flowers a very striking and attractive appearance.

Countess of Lonsdale-Longest season and freest bloom of any Cactus type; flowers very large, complete and perfect. Color, an exquisite warm blending of amber and salmon pink.

Standard Bearer-Bright, pure scarlet. Flowers large, thick and full to center, of symmetrical and perfectly round form, petals semi-quilled. Extraordinarily productive and one of the best red cut flowers.

PIUS $X-A$ beautiful, large, white flower of slight sulphur tint; very double; with nicely quilled petals; fine cutflower.

Strong roots of any of the foregoing varieties, 15 cts. each; $\$ 1.50$ dozen.

\section{DOUBLE DAHLIAS}

Each. Doz.

Double-Finest varieties in distinct colors $15 \phi$

Fine Mixed Varieties............. 10

\section{DOUBLE DAHLIAS}

\section{Best Standard Decorative and Show Type.}

This type is the most formal and perfect in shape, composed of short, numerous quills of varying character. They make excellent compact bouquets and usually outlast the other types. 


\section{GLADIOLI}

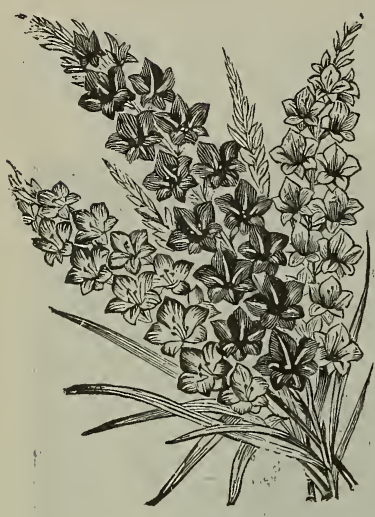

The most beautiful and desirable of all summer flowering bulbs, has become a general favoriteandexceedingly popular wherever known. The Gladiolus is of the easiest culture in any good garden soil, and may be planted from April to the middle of June. Set the bulbs four inches deep, and eight or ten inches apart. For a long succession of bloom plant the bulbs at intervals of ten or twelve days.

\section{CHOICE GLADIOLI}

America-Beautiful, soft flesh-pink (much like "Enchantress" Carnation), faintly tinged with lavender. Spikes develop very evenly and to unusual length, sometimes with two or three branches. A magnificent cutflower; it took the flower loving world by storm when first introduced and holds undisputed first place among all Gladioli, with unabated popularity. $8 \mathrm{cts}$. each; 75 cts. doz.; $\$ 5.00$ per 100 .

Augusta-White ground color with blue shading. Fine variety as it is very vigorous and spikes are large and fine. 5 cts. each; 50 cts. doz.; $\$ 3.50$ per 100 .

Brenchleyensis-Deep vermillion scarlet. One of the brightest and most showy varieties. 4 cts. each; 40 cts. doz.; $\$ 3.00$ pre 100 .

Ceres-Pure white, spotted with purplish-rose. 6 cts. each; 60 cts. doz.; $\$ 4.00$ per 100.

Mrs. Frances King-Light scarlet of pleasing shade, large spike and flower. 6 cts. each; $60 \mathrm{cts}$. doz.; $\$ 4.00$ per 100.

\section{CHOICE SEEDLINGS AND UNNAMED GLADIOLI}

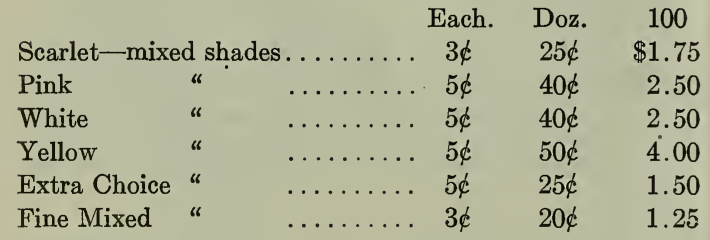

\section{JAPANESE IRIS (Iris Kaempferi)}

These flowers often measure ten to twelve inches in diameter, and are of the most varied and beautiful colors. They require rich, moist soil. Our collection is a direct importation from Japan and is remarkably fine. Named varieties; strong clumps. Each 30 cts. By mail, 35 cts. each; doz. $\$ 3.00$.

Choice Mixed Sorts -25 cts. each; $\$ 2.50$ doz.; $\$ 15.00$ per 100.

\section{LILIES}

The undernoted varieties of these popular and beautiful flowers are hardy and require little attention after planting; the bulbs should be planted six inches deep, in a well drained location where they can remain undisturbed.

Auratum-(Golden Rayed Lily of Japan)-large size bulbs.... . 20ф

Medium size bulbs.......15e

Speciosum Roseum-W hit e rose-spotted....15\&

Speciosum Rub-

rum - L a r ge

bulbs........ $15 \notin 1.50$

$\$ 2.00$

1.50

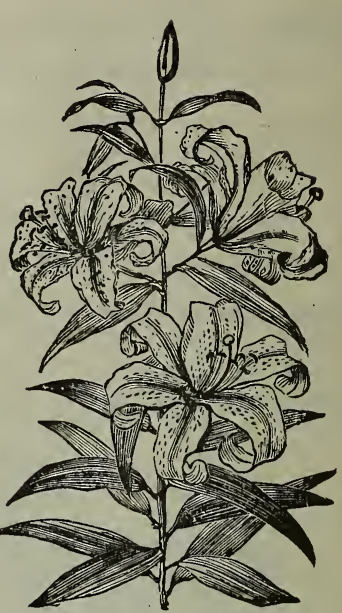

Lilium Auratum
Tigrinum (Single Tiger Lily)-Very hardy, orange-red spotted with black, 10 cts. each; $\$ 1.00$ per doz.

Tigrinum (Double Tiger Lily) - 15 cts. each; $\$ 1.50$ per doz.

\section{TUBEROSES}

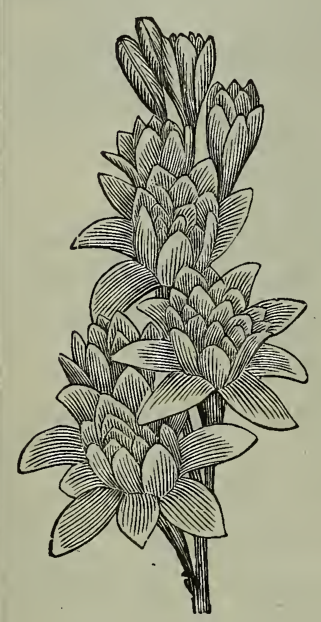

The bulbs may. be planted from February to June for a succession of flowers, and plant in the open ground about the end of May. Our Tuberoses are about certain to bloom, being carefully grownand selected.

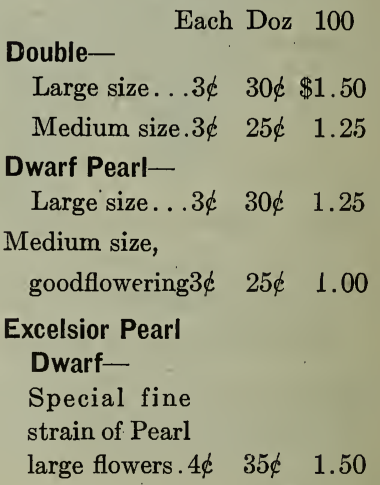

\section{MADEIRA VINE}

The Madeira Vine is of rapid growth, with dense and beautiful foliage, twining to great height. It grows anywhere, but does better in a warm, sunny, sheltered location. It is also a very pretty plant for training around the windows in the house. Strong Tubers, ea., 5 cts.; 3 for 10 cts.; per doz., 30 cts. 


\section{Hardy Herbaceous Perennial Plants.}

For such of our customers who are not acquainted with the different varieties we shall be pleased to make suitable selections of the most desirable species, that when once planted, with very little care, will keep the garden gay with flowers from the time frost leaves the ground until late in autumn.

15 cents each, $\$ 1.50$ per dozen (except where noted). If sent by mail 20 cents each.

ANCHUSA ITALICA DROPMORE VARIETY. A strong growing plant, 5 to 6 feet high, with broad foliage and large spikes of beautiful blue flowers the entire season.......................... 20 each; $\$ 2.00$ per dozen. ASTERS, HARDY. Blooms in September and October; colors blue, lilac, crimson and white, mixed sorts. $1 \frac{1}{2}$ to 3 feet.

BAPTISIA, AUSTRALIS (False Indigo). Strong grower, with .dark green, deeply cut foliage and spikes af dark blue

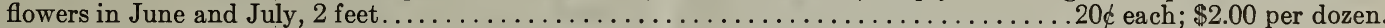

BOCCONIA CORDATA. An attractive plant, growing 6 to 8 feet high with large foliage and long spikes of white flowers in August. Well adapted for single lawn specimens......................20 each; $\$ 2.00$ per dozen.

BOLTONIA LATISQUAMA (False Chamomile). Large single Aster-like flowers, blooming profusely during summer and autumn. Pink, slightly tinged with lavender. 4 to 6 feet.

CHRYSANTHEMUM, HARDY. These beautiful small-flowered varieties are very popular for out-door bedding purposes. They are hardy; with a slight covering of leaves or coarse stable litter during the winter. They will pro-

duce an abundance of bloom until killed by frost.

CHRYSANTHEMUM, MAXIMUM. A free-growing plant, not exceeding $2 \frac{1}{2}$ feet in height, forming bushy plants, which continue in full bloom from June to August. The flowers are 3 inches and over in diameter, pure white with a golden center. They are of great substance and last a week or more when cut.

COREOPSIS LANCEOLATA. A beautiful hardy border plant; grows 15 to 18 inches high, and produces its bright, golden-yellow flowers in great profusion the entire season.

DICTAMNUS FRAXINELLA (Gas Plant). A showy old-fashioned border plant with fragrant foliage and spikes of curious showy rosy pink flowers in June and July.

FUNKIA SUBCORDATA GRANDIFLORIA ALBA (August Lily): Pure white, lily-shaped, fragrant flowers; borne in large clusters

FUNKIA UNDULATA VARIEGATA. Foliage green, striped with white

GAILLARDIA GRANDIFLORA. Beginning to flower in June, they continue one mass of bloom the entire summer. Flower, 3 inches in diameter; center dark reddish brown; petals vary from scarlet orange to crimson.

HELIANTHUS, MAXIMILLIANA. Single-flowered variety; growing from 5 to 7 feet high; September and October. The flowers are produced in long, graceful sprays, which make it invaluable for cutting purposes.

HELIANTHUS, MULTIFORUS FI. PI. (Double Hardy Sunflower). One of the most useful perennial plants. It produces its large, double Dahlia-like golden yellow flowers in great profusion during July and August; 4 feet.

HELIANTHUS RIGIDUS. A desirable variety, beginning to bloom early in July and continuing until fall; flowers single golden-yellow, with dark centers; 3 feet.

HELIANTHUS, SOLEIL D'OR. Deep golden-yellow, quilled petals, not unlike a Dahlia; 4 feet; August and September.

HIBISCUS, "CRIMSON EYE." Flowers of immense size. Color white, with a large spot of deep crimson in the center.

HOLLYHOCK. For planting in rows or groups on the lawn, or for interspersing among shrubbery, they are invaluable. The flowers form perfect rosettes of the most lovely colors. They require a rich, deep soil, well drained, and will repay in quantity and elegance of bloom any extra care. A slight protection during the winter will be beneficial. Double and single. Assorted colors.

LYTHRUM ROSEUM SUPERBUM (Rose Loose Strife). A strong growing plant, 3 to 4 feet high, producing large spikes of rose colored flowers from July to September.

MERTENSIA VIRGINICA (Blue Bells). An early spring flowering plant growing about 1 to $1 \frac{1}{2}$ feet high, with drooping panicles of handsome light blue flowers, changing to clear pink; one of the most interesting of our native spring flowers; May and June.

MONARDA DIDYMA (Oswego Tea). Large brilliant scarlet flowers; a very showy plant; 2 to 3 feet.

PAEONIES. These are absolutely hardy everywhere, have no insect enemies, and the brilliant beauty of their flowers both in color and form will satisfy the most exacting. As the plants become established the size and quality of the blossoms increase in beauty. Our collection embraces a fine assortment in color and variety. $25 \dot{c}$ each; $\$ 2.50$ per doz.; extra large clumps, $50 \notin$ to $\$ 1.00$ each.

PHLOX DECUSSATA (Hardy Phlox). One of the finest hardy flowering plants. They succeed well in any good garden soil, but are greatly improved by being liberally manured and an application of liquid manure during the growing season will increase the size of the flower truss. When in flower they should be watered freely every evening. A succession of bloom can be had from June until October by planting in varieties; 30 inches.

PHYSOSTEGIA VIRGINICA. One of the most beautiful of our mid-summer flowering perennials, forming dense bushes 3 to 4 feet high bearing spikes of delicate tubular pink flowers; extra strong plants.....25c each; $\$ 2.50$ per dozen.

PLATYCODON MARIESI. Deep blue, bell-shaped flowers, nearly 3 inches across; 1 to 2 feet high.

POPPY, ICELAND. These range in color from white and yellow to orange scarlet. Height 12 to 18 inches. Often hundred flower stems on a single plant. Bloom from June to October............20 each; $\$ 2.00$ per dozen.

POPPY, ORIENTAL. Nothing can equal these in gorgeous effect, and whether planted singly or in masses, their large flowers, rich coloring and freedom of bloom render them conspicuous in any position. They grow three feet high and bloom in May and June. Finest Mixed Varieties.

RUDBECKIA (Golden Glow). One of the most desirable, effective flowering plants for July and August. It grows six feet high, branching freely and throwing up masses of large double yellow flowers. Invaluable for cutting.

RUDBECKIA PURPUREA, the giant purple cone flower; flowers four inches across.

SHASTA DAISY. Perfectly hardy, of easy cultivation and blooms for several months. The flowers are large, 4 to 5 inches across, with large broad petals of the purest white. June to October.

STOKESIA CYANEA (Cornflower Aster). Produces showy Aster-like deep blue flowers which measure from 4 to 5 inches across. It is of the easiest culture, succeeding in any open sunny position. The plant grows from 18 to 24 inches high, blooming freely from July until frost.

TRITOMA PFITZERII, the flower spikes, which are produced freely, are of gigantic size, frequently $4 \frac{1}{2}$ feet high, with heads of bloom over 21 inches long of rich orange-scarlet, shading to a salmon rose on the edge. A first-class

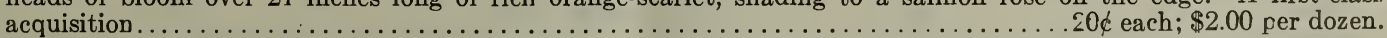

To get best results from all kinds of clover, as well as beans and peas, use Farmogerm, listed on page 24 . The greatest advance in growing certain crops ever known. 


\section{Everblooming Roses.}

The tea-scented ever-blooming Roses are admired for their delicious fragrance, free-blooming qualities, and the exquisite form and coloring of their flowers. They make excellent bedders, and yield a succession of bloom through the entire season.

American Beauty (Hybrid Tea)-Deep rose shaded towards center, a rich carmine crimson; delicious fragrance. Strong Plants 50 cts. each; $\$ 5.00$ doz. Medium Plants, 25 cts. each; $\$ 2.50$ dozen.

\section{HARDY HYBRID PERPETUAL ROSES}

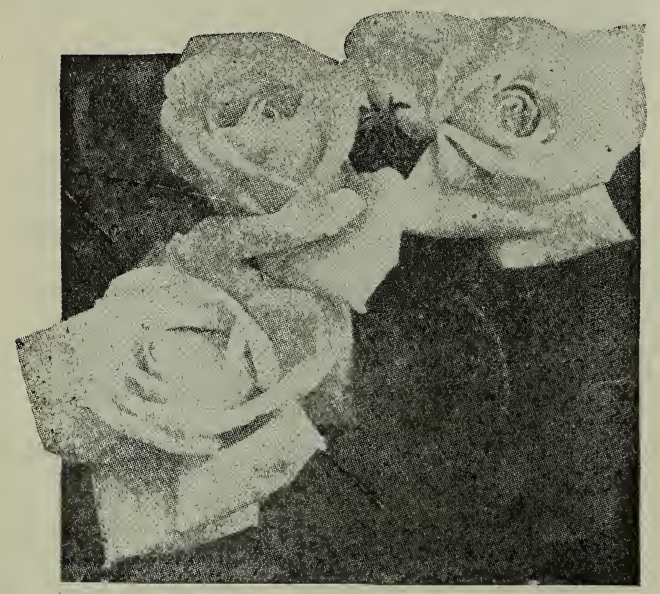

Alfred Colomb, bright carmine red.

Gen'l Jacqueminot, rich crimson.

Victor Verdier, rose, free bloomer.

Coquette des Alps, white shaded crimson.

La Reine, rosy pink.

Martha Washington, fine white.

Anna de Diesbach, bright rose, fragrant.

Jules Margotten, deep rose, large and fine.

Madame Gabriel Luizet, silvery, pink, large.

Paul Neyron, dark rose, rich, fragrant.

Prince Camille de Rohan, dark crimson.

Magna Charta, bright, pink, large, fragrant.

Small Plants, 15 cts. each; $\$ 1.50$ per doz.

Large 2 year Dormant Plants, 30 cts. each, $\$ 3.00$ per doz.

\section{EVERBLOOMING ROSES}

Catherine Mermet, bright flesh color.

Bon Silene, deep rose.

Devoniensis, creamy white.

Hermosa, pink, very double.

General Tartas-An old Rose, but one that has many admirers; color, rich, deep rose.

Golden Gate-Rich creamy-white with center and base of petals soft yellow, frequently tinted with soft rose; free bloomer.

Homer-Rose-salmon center; free bloomer; very pretty.

Killarney-The finest pink forcing Rose ever introduced. In coloring it is especially beautiful, being an exquisite shade of deep seashell-pink. The buds and flowers are of enormous size, the petals being frequently two and one-half inches deep.

Small Plants-15 cts. each; $\$ 1.50$ per doz.

Large Plants- 30 cts. each; $\$ 3.00$ per doz.

\section{HARDY CLIMBING ROSES}

Baltimore Belle-Double. Pale blush, nearly white.

Crimson Rambler-The flowers are produced in trusses, fairly covering the plant from the ground to the top, so that it is one mass of glowing crimson. The profusion of bloom is marvelous, over three hundred blossoms having been counted on one shoot. Strong and vigorous.

Pink Rambler-Pure satiny rose, single in clusters. The partially open buds being bright, light carmine, thus producing a strong and pleasing contrast.

White Rambler-Closely resembles the Crimson Rambler in vine and foliage. Large clusters of pure white flowers, which are deliciously fragrant. The flowers remain on the plant a long time and keep a long time when cut.

Yellow Rambler-The flowers are borne in immense clusters, often as many as 150 blossoms in a bunch. The color is a decided yellow; the flowers are very fragrant; the habit of growth is very vigorous. Well established plants often making shoots 8 to 10 feet in one season. Large Plants -30 cts. each; $\$ 3.00$ per dozen.

Extra Strong Plants-50 cts. each; $\$ 5.00$ per dozen.

Large Rose Plants can only be sent by Express, at purchaser's expense.

\section{GENERAL LIST OF BEDDING PLANTS}

\begin{tabular}{|c|c|c|c|c|c|c|c|}
\hline Ageratum, blue. & $\begin{array}{c}\text { Each. } \\
10 d\end{array}$ & & Doz. & Marioolds, sorts, & $\begin{array}{c}\text { Each. } \\
5 \varnothing\end{array}$ & & $\begin{array}{r}\text { Doz. } \\
.50\end{array}$ \\
\hline Iternanthera, of sorts. & $8 \notin$ & & $\begin{array}{r}\$ .75 \\
.75\end{array}$ & Nasturtiums, sorts.......... & 56 & & \\
\hline Asters, assorted colors. . . . . & $5 \notin$ & & .50 & Pansies............... & $5 \&$ to $10 \phi$ & $\$ 0.50$ to & \\
\hline Cannas, Dwarf, started..... & $15 \phi$ & & 1.50 & Petunia, double; sorts..... & $15 \phi$ & & 1.5 \\
\hline Centaurea Gymnocarpa... . . & $10 \notin$ & & 1.00 & Petunia, single; sorts...... & $10 \dot{c}$ & is & 1.00 \\
\hline Coleus, new sorts.......... & $8 \dot{6}$ & & .75 & Phlox Drummondii. . . . . . . . & $5 d$ & & .5 \\
\hline Chrysanthemums.......... & $15 \phi$ & & 1.50 & Salvia, scarlet. . & $10 \notin$ & & 1.00 \\
\hline Geranium, sorts........ $10 \notin$ to & 0156 & $\$ 1.00$ to & 01.50 & Verbenas, finest... & $8 \notin$ & & .7 \\
\hline Heliotrope, sorts. . . . . . . & $10 \notin$ & & 1.00 & Vincas, sorts..... & $8 d$ & & .7 \\
\hline$\ldots \ldots \ldots \ldots$ & $10 \notin$ & & 1.00 & Zinnias, sorts. . . . . . . . . & $5 \notin$ & & .50 \\
\hline Lobelias, sorts. . . . . . . . . . & $8 \notin$ & & .75 & & & & \\
\hline
\end{tabular}




\section{Ornamental Flowering Shrubs.}

Althea (Rose of Sharon)-The Altheas are among the most valuable of our hardy Shrubs on account of their late season of blooming which is from August to October, a period during which but few shrubs or trees are in flower. They are also extensively used as hedge plants, for which they are admirably adapted.

Double Rose, Double White and Double Purple................

Small Plants.................

Azalea Amoena-A bushy dwarf evergreen with small green leaves that deepen to a lustrous coppery hue in winter. Its neat appearance is attractive at all seasons but in April or May the whole plant is a mass of brilliant rosy crimson flowers that hold their beauty three or four weeks. .................

Berberis Purpurea (Purple-leaved Barberry), an interesting shrub growing 3 to 5 feet high with violet purple foliage and fruit; very effective in groups and masses, or planted by itself. Srong plant $50 \mathrm{cts}$. each, $\$ 5.00 \mathrm{doz}$.

Berberis Thunbergii-A beautiful Japan variety of dwarf habit. Small foliage assuming the most varied and beautiful tints of coloring in the autumn; very desirable for grouping and a grand hedge plant...............

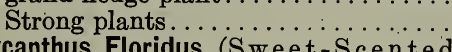

Calycanthus Floridus (Sweet-Scented Shrub). Flowers fragrant, like strawberries; double and of a chocolate color...................... $25 \phi$

$30 \notin \quad 3.00$

$50 \notin \quad 5.00$

$25 £$

.00
Doz.

$50 \notin \quad \$ 5.00$

$30 \notin \quad 3.00$

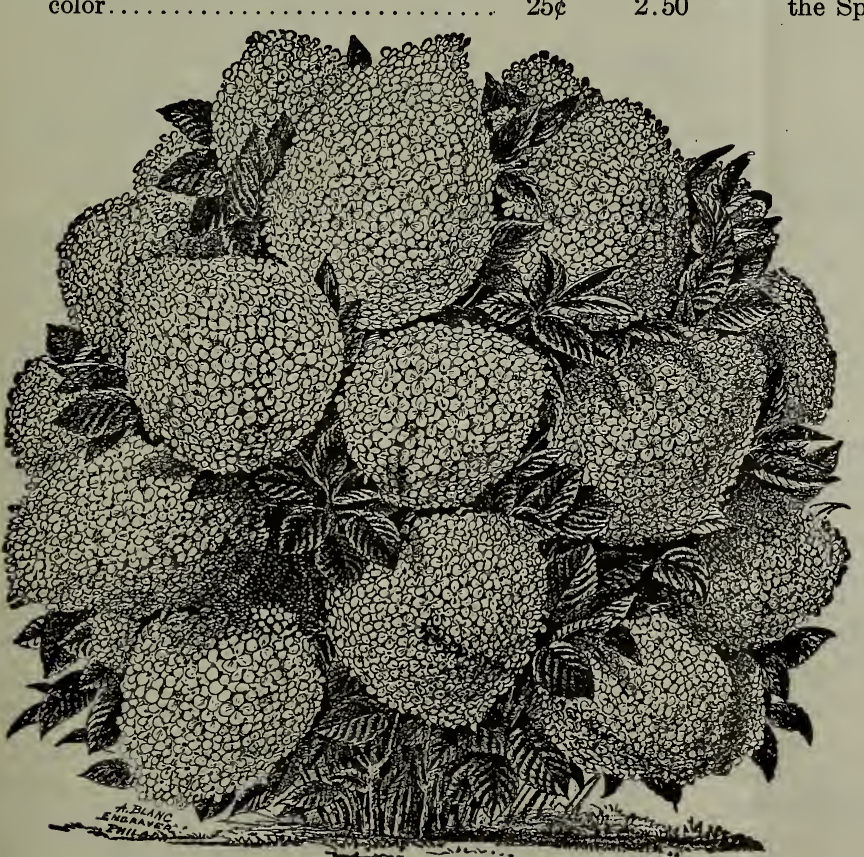

and cold extremely well. The Each

flowers, which are borne in dense pyramidal panicales in the greatest profusion, are white when they first open, but gradually change to rose and remain in good condition for weeks. Extra strong plants.

Hydrangea Paniculata Grandiflora Standard or Tree Shaped Plants-These are fine specimen plants, four and five years old, trained to tree shape with about three feet of straight stem and nicely shaped heads, should bloom profusely the first year........... Extra strong plants................

Lilac, Named Varieties-Standard or three shaped plants.

Lilac, Common (Syringa Vulgaris) - The common purple species, and one of the best, 3 feet.

Lilac, Common White (S.Vulgaris) alba.. Flowers pure white; very fragrant, 2 feet...................

Philadelphus Coronarius (Mock Orange or Syringa).-A well known shrub, with pure white, highly scented flowers. One of the first to flower.......... Extra strong plants................. in early spring; flowers dazzling scarlet. Makes an excellent hedge, 3 feet

Snow Ball (Viburnum Sterlis.)-A hardy shrub, growing 8 to 15 feet, producing large balls of snowy white flowers in June... $\ldots \ldots \ldots \ldots \ldots \ldots \ldots \ldots \ldots \ldots$. . . . . . . . . the Spireas; it is a beautiful ornament for the lawn at any season, but 'when in flower it is a complete fountain of white bloom. Clusters of 20 to 30 white florets make up the racemes, and these clusters are set close along the drooping stems. Perfectly hardy and an early bloomer.. Extra strong plants....

Weigelia Eva Rathke-

A charming variety, flowers brilliant, a beautiful crimson; distinct, clear $\begin{array}{ll}\text { shade................. } & 30 \notin \\ \text { Extra strong plants.... } & 50 \phi\end{array}$

Weigelia Rosea Nana Vareigata

-Leaves beautiful margined creamy white; flowers pink. It is a dwarf grower, and adapted to small lawns or gardens 3 feet......... Extra strong plants.....

Yucca Filamentosa-A magnificent, hardy plant, with large, pointed evergreen leaves, flower spikes growing from 5 to 6 feet high, with beautiful lily-shaped flowers, lemon scented ............ $25 \phi$

Hydrangea Paniculata Grandiflora-This is the finest shrub in cultivation, and endures heat

We are prepared to furnish at special prices, large specimen plants of several varieties of ornamental flowering shrubs and trees that will produce an immediate effect when properly planted. 


\section{Shade and Ornamental Trees.}

\section{FOR LAWN, STREET AND FOREST PLANTING.}

We enumerate below the principal varieties of Shade and Ornamental Trees, etc., all Strictly Selected Stocks, and while our aim is to supply First Quality only, still, we are in position to meet honorable competition on any size or quality; therefore it will be to your advan tage to submit an estimate of your wants.

Alnus, (Adler) -

Each. Doz.

European.

12 to $14 \mathrm{ft} . \$ 1.25 \$ 12.00$

Imperial Cut-leaved . . . . 10 to $12 \mathrm{ft.} 2.00 \quad 17.50$

Ash-

American White....... 8 to $10 \mathrm{ft} .2 .00$

American White $2 \frac{1}{2}$ to 3 in. $\quad 1.00$

American Green $1 \frac{1}{2}$ to 3 in. $\quad 1.00$

American Green 2 to $2 \frac{1}{2}$ in. $\quad 1.50$

European $1 \frac{1}{2}$ to 2 in..... $\quad 1.50$

Mountain.......... 8 to $10 \mathrm{ft} . \quad 1.00$

Mountain..........10 to $12 \mathrm{ft}$. 1.25

Beech-

Purple Leaved........ 5 to $6 \mathrm{ft}$. $1.25 \quad 12.00$

Birch-

European White, $1 \frac{1}{2}$ to 2 in

$1.25 \quad 12.00$

European White, 2 to $2 \frac{1}{2}$ in

$1.50 \quad 15.00$

Purple leaved........ 5 to 6 in. 1.25

\section{Catalpa-}

$1 \frac{1}{2}$ to 2 in............ 1.25

$2 \frac{1}{2}$ to 3 in............ $\quad 2.00$

Bungei, a fine umbrella-

headed tree, top grafted,

3 -year specimen....... 7 to $10 \mathrm{ft} . \quad 2.50$

2-year specimen......6 to $7 \mathrm{ft} . \quad 1.25$

\section{Cercis Canadensis-}

(Red Bud).......... 5 to $6 \mathrm{ft} . \quad 1.00$

(Red Bud).........6 to $8 \mathrm{ft} . \quad 1.25$

10.00

12.50

\section{Cherry-}

Bird...........6 to $8 \mathrm{ft} . \quad .75$

James Veitch.......... 1.50

7.50

Japan Double Flowering. . 4 to $5 \mathrm{ft}$. $1.25 \quad 12.00$

Cornus Florida (Dogwood)-

White Flowering . .....4 to $5 \mathrm{ft} . \quad 1.00 \quad 10.00$

Red Flowering . . . . . 2 to $3 \mathrm{ft} . \quad 1.50 \quad 15.00$

Crab Apple-_"Betchell's"-

Double Flowering. . . . . 4 to $5 \mathrm{ft}$. $1.00 \quad 10.00$
Crab Apple-

Each. Duz.

Parkmanni..........4 4 to $5 \mathrm{ft}$. $1.00 \quad 10.00$

\section{Cypress-}

Deciduous.........6 to $8 \mathrm{ft} . \quad 1.25 \quad 12.00$

Elm-

American.......... 8 to $10 \mathrm{ft} . \quad .75 \quad 7.50$

American $1 \frac{1}{2}$ to 2 in...... $\quad 1.75 \quad 17.50$

American, $2 \frac{1}{2}$ to 3 in..... $\quad 3.50 \quad 35.00$

English, $1 \frac{1}{2}$ to 2 in....... $\quad 1.75 \quad 17.50$

English, 2 to $2 \frac{1}{2}$ in....... $\quad 2.50 \quad 25.00$

Scotch........... 8 to $10 \mathrm{ft.} \quad 1.00 \quad 10.00$

Scotch, $1 \frac{3}{4}$ to 2 in...... $\quad 2.00 \quad 21.00$

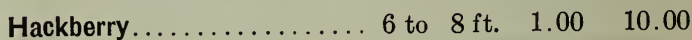

Horse Chestnut-

White Flowering. . . . . 6 to $7 \mathrm{ft} . \quad 1.50 \quad 15.00$

Red Flowering........4 to $5 \mathrm{ft}$. $1.50 \quad 15.00$

American Buckeye....... 3 tc $4 \mathrm{ft.} \quad .75 \quad 7.50$

Dwarf...........2 to $3 \mathrm{ft}$. $1.25 \quad 12.00$

Kentucky Coffee Tree. . . . . . 4 to 5 ft. $.75 \quad 7.50$

Koelreuteria, Paniculata..... 6 to $8 \mathrm{ft} . \quad 1.00 \quad 10.00$

Laburnum-

Scotch...........6 to $8 \mathrm{ft} . \quad 1.00 \quad 10.00$

Larch-

European............6 6 to $8 \mathrm{ft}$. $.75 \quad 7.50$

European............ 8 to $10 \mathrm{ft} . \quad 1.00 \quad 10.00$

Linden-

American, $1 \frac{1}{2}$ to 2 in.... $\quad 1.50 \quad 15.00$

American, 2 to $2 \frac{1}{2}$ in ..... $\quad 2.50 \quad 25.00$

European............ 8 to $10 \mathrm{ft} . \quad 1.25 \quad 12.00$

European, $1 \frac{1}{2}$ to 2 in..... $\quad 1.75 \quad 17.50$

Silver or White Leaf . . . 8 to $10 \mathrm{ft.} \quad 1.25 \quad 12.00$

\section{Liquidamber-}

Sweet Gum, $1 \frac{1}{2}$ to 2 in... $\quad 1.50 \quad 15.00$

Sweet Gum, 2 to 3 in... $\quad 2.50 \quad 25.00$

Maple-

Norway........... 8 to $10 \mathrm{ft.} \quad 1.25 \quad 12.00$

Scarlet...........6 6 to $8 \mathrm{ft} . \quad 1.25 \quad 12.50$

Scarlet, $1 \frac{1}{2}$ to $1 \frac{3}{4}$ in ..... $\quad 2.00 \quad 21.00$

Scarlet, 2 to $2 \frac{1}{2}$ in...... $\quad 3.00 \quad 30.00$

Rock or Sugar....... 8 to $10 \mathrm{ft}$. $\quad 1.25 \quad 12.00$

Rock or Sugar. . . . . . . 10 to $12 \mathrm{ft.} \quad 2.00 \quad 20.00$

Weir's Cut-Leaved.......10 to $12 \mathrm{ft}$. $1.25 \quad 12.50$

Silver or Soft........ 8 to $10 \mathrm{ft}$. $\quad .75 \quad 7.50$

Silver or Soft, $1 \frac{1}{2}$ to 2 in.. $\quad 1.25 \quad 12.50$

Silver or Soft, 2 to $2 \frac{1}{2}$ in.. $\quad 2.00 \quad 20.00$

We do not carry Nursery Stock in store, but obtain same from several of the leading and most reliable Nurseries in this part of the country. It usually requires a week or ten days to fill orders. 


\section{SHADE AND ORNAMENTAL TREES-Continued}

Maple-Continued

Cork Bark. 8 to $10 \mathrm{ft} . \$ 1.25 \$ 12.50$

Schwedleri. 8 to $10 \mathrm{ft} .2 .00$

21.00

Ash-Leaved (Box Elder),

$1 \frac{1}{4}$ to $1 \frac{1}{2}$ inch..........

$1.00 \quad 10.00$

Ash-Leaved (Box Elder),

$1 \frac{3}{4}$ to 2 inch...........

$1.25 \quad 12.50$

Ash-Leaved (Box Elder),

2 to $2 \frac{1}{2}$ inch..........

Sycamore. . 8 to $10 \mathrm{ft} .1 .00$

Sycamore. .10 to $12 \mathrm{ft} . \quad 1.50$

15.00 10.00 15.00

Oak-

Red, $1 \frac{1}{4}$ to $1 \frac{1}{2}$ inch......

Red, $1 \frac{1}{2}$ to 2 inch.......

Scarlet.

1.50

Scarlet, $1 \frac{1}{2}$ to 2 in......

2.50

Pin

1.50

Pin, $1 \frac{1}{2}$ to 2 in

2.50

Burr or Mossy Cup..... 8 to $10 \mathrm{ft}$. 1.50

Burr or Mossy Cup, $1 \frac{1}{2}$ to

$$
2 \text { in }
$$

Chestnut, 2 to $2 \frac{1}{2}$ in .....

3.00

White.

1.75

3.00

White, 2 to $2 \frac{1}{2}$ in...........

1.50

English........... 8.to $10 \mathrm{ft}$.

2.00

English, $1 \frac{1}{2}$ to 2 in.......

3.00

English, $2 \frac{1}{2}$ to 3 in

Olive-

Russian 4 to $6 \mathrm{ft}$.

Paulownia Imperialis-

(Empress Tree).......4 to $5 \mathrm{ft} . \quad 1.00$ 10.00

\section{Peach-}

Clara Meier_Double Red, extra fine............

Double Flowering, Red... 4 to $5 \mathrm{ft}$. 60

Double Flowering, White. 4 to $5 \mathrm{ft}$. .60

\section{Persimmon-}

American 8 to $10 \mathrm{ft} . \quad 1.25$

12.50

Poplar-

Carolina............ 8 to 10 ft. $\quad .60 \quad 6.00$

Carolina, $1 \frac{1}{2}$ to $1 \frac{3}{4}$ in.....
Poplar-Continued

Each. Doz.

Balsam, (Balm of Gilead),

2 to $2 \frac{1}{2}$ in.............................

Golden Aurea........ 8 to $10 \mathrm{ft}$.

$\$ 1.50 \$ 15.00$

Lombardy........... 8 to $10 \mathrm{ft}$.

Lombardy..........10 to $12 \mathrm{ft}$.

7.50

7.50

10.00

\section{Prunus Pissardi-}

Purple Leaf Plum...... 5 to $6 \mathrm{ft}$. $\quad .60 \quad 6.00$

\section{Salisburia-}

Maiden Hair or Ginkgo. . 8 to $10 \mathrm{ft} . \quad 1.25 \quad 12.50$

\section{Sycamore-}

American........... 8 to $10 \mathrm{ft.} \quad 1.00 \quad 10.00$

American, $1 \frac{1}{2}$ to $1 \frac{3}{4}$ in... $\quad 1.50 \quad 15.00$

American, 2 to $2 \frac{1}{2}$ in.... $2.50 \quad 25.00$

European........... 8 to $10 \mathrm{ft}$. $1.00 \quad 10.00$

Thorn-

Paul's Scarlet......... 3 to $4 \mathrm{ft}$. $.75 \quad 7.50$

Paul's White......... 3 to $4 \mathrm{ft}$. $75 \quad 7.50$

Coccinea (Scarlet).....4 to $5 \mathrm{ft}$. $\quad .75 \quad 7.50$

Tulip Tree-

8 to $10 \mathrm{ft} \ldots \ldots \ldots \ldots \ldots .60$

$1 \frac{1}{2}$ to 2 in............. $\quad 1.50 \quad 15.00$

2 to $2 \frac{1}{2}$ in ............ $2.00 \quad 20.00$

\section{WEEPING TREES}

Beech, Pendula........... 8 to $10 \mathrm{ft.} 3.00 \quad 30.00$

Birch, Cut-Leaved......... 8 to $10 \mathrm{ft} . \quad 1.50 \quad 15.00$

Cherry, Japanese. . .2 yrs' head $\quad 1.75 \quad 17.50$

Elm, Camperdown..2 yrs' head $\quad 1.25 \quad 12.50$

Mountain Ash....2 yrs' head $\quad 1.00 \quad 10.00$

Willow, Kilmarnock........4 4 to $6 \mathrm{ft}$. $1.00 \quad 10.00$

Willow, Babylonica, $1 \frac{1}{4}$ to $1 \frac{1}{2}$ in. $\quad 1.00 \quad 10.00$

\section{NUT BEARING TREES}

Almonds, Soft Shell ........ $\quad .50$

5.00

Chestnuts, American........ 5 to $6 \mathrm{ft}$. $\quad .60 \quad 6.00$

Chestnuts, American........6 6 to $8 \mathrm{ft}$. $.75 \quad 7.50$

Chestnut, Spanish......... 3 to $4 \mathrm{ft} . \quad .60 \quad 6.00$

Chestnuts, Japan. . . . . . 3 to $4 \mathrm{ft}$. $\quad .75 \quad 7.50$

Filbert, English......... 4 to $5 \mathrm{ft}$. $.75 \quad 7.50$

Hickory, Shell Bark. . . . . . 2 to $3 \mathrm{ft} . \quad 1.00 \quad 10.00$

Pecans............... 5 to $6 \mathrm{ft}$. $.75 \quad 7.50$

Pecans............... 6 to $8 \mathrm{ft} . \quad 1.00 \quad 10.00$

Walnuts, English......... 3 to $4 \mathrm{ft}$. $50 \quad 5.00$

Walnuts, Black..........6 to $8 \mathrm{ft}$. $75 \quad 7.50$

Walnuts, Japan.......... 5 to $6 \mathrm{ft} .1 .00 \quad 10.00$

Walnuts, White (butternut)... 6 to $8 \mathrm{ft}$. $\quad .75 \quad 7.50$ 


\section{HEDGE PLANTS.}

Althea, (Rose of Sharon)-The Altheas are among the most valuable of our Tall Hardy Shrubs on account of their late season of blooming. They are extensively used as hedge plants, for which they are admirably adapted, strong, bushy plants.

$\$ 2.00$ per doz.; $\$ 15.00$ per 100

Berberis Thunbergii, where a low dwarf, deciduous hedge is wanted nothing equals this beautiful Barberry. It is of spreading habit, growing extremely thick right from the base, and requires but little pruning to keep it in shape. The leaves are small light green, and toward fall assumes rich, brilliant colors; the fruit or berries becoming scarlet.

$\$ 2.00$ per doz.; $\$ 15.00$ per 100

Osage Orange-This is still used extensively on farms and along highways. It makes a strong defensive hedge that will turn cattle; should be planted in double rows, six to nine inches apart in a row. Strong two-year-old plants, 60 e per $100 ; \$ 5.00$ per 1,000 .

Privet Amurense (Amoor River).-A hardy variety with large, oblong, glossy green foliage. Extra heavy plants. $\$ 1.50$ per doz.; $\$ 10.00$ per 100 .

Privet California.-(Ligustrum Ovalifolium.)Of all ornamental hedge plants this is the most popular, and more of it is planted than all others combined. Its foliage is a rich dark green, and is nearly evergreen, remaining on the plant until mid-winter. It is of free growth and succeeds under the most adverse conditions, such as under dense shade of trees, where other plants would not exist. The most advantageous manner of planting is in double rows, the two rows being about eight inches apart. The plants should be set 12 to 15 inches apart in the row, alternating the plants. In order to secure a dense hedge from the base up, the plants should be severely pruned the first two seasons.

2 Year Old Plants, 75 \& doz.; $\$ 4.00$ per $\cdot 100$.

3 Year Old Plants, $\$ 1.00$ doz. ; $\$ 6.00$ per 100.

Extra Large Bushy Plants, $\$ 1.50$ per doz.;

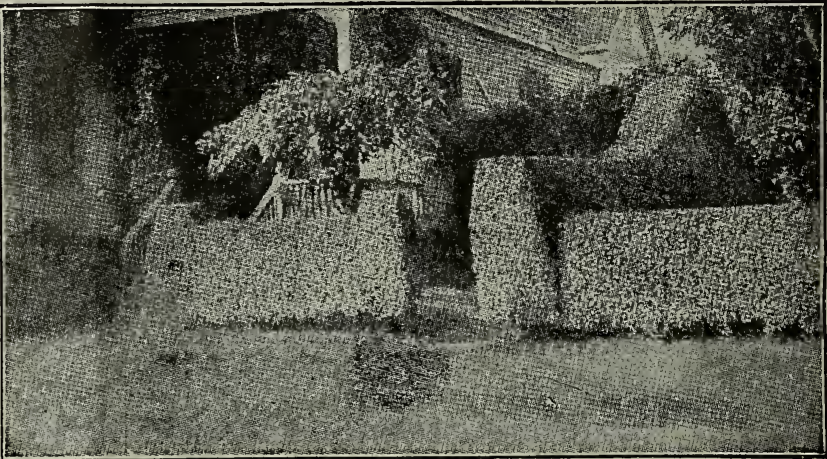

$\$ 10.00$ per 100 .

\section{HARDY CLIMBING PLANTS.}

Ampelopsis Veitchii (Japan Creeper or Boston Ivy) - The leaves are small on young plants, which at first are of an olive green color, changing to red in the autumn. As the plant acquires age the leaves increase in size. Without question one of the very best climbing plants for covering brick or stone walls that can be grown. $25 \phi$ each; $\$ 2.50$ doz.; by mail, $30 \notin$ each.

Aristolochia Sipho (Dutchman's Pipe)-A magnificent hardy vine of rapid growth, with very large heart-shaped leaves, and brownish flowers, resembling a pipe. 50غ each; $\$ 5.00$ doz.; by mail, 60 c each.

Celastrus Scandens (Climbing Bitter Sweet).-Of rapid growth, light green foliage and yellow flowers during June, which are followed in the autumn with orange fruit. $25 \notin$ each; $\$ 2.50$ per doz.

Clematis-Large Flowered Varieties. In this superb family of hardy climbers, many of the varieties have flowers 5 to 7 inches in diameter. They are grand for pillars and trellises, pegged down for bedding and for running over rockwork, old trees and stumps. They delight in rich soil, and a sunny situation, and are perfectly hardy.

Henryi-Creamy white.

Jackmani-Velvety, violet-purple.

Mad. Ed. Andre-Crimson-red.

2 year-50\& each; $\$ 4.00$ per 10 .

Paniculata - Glossy green foliage and mass of fragrant white flowers. One of our best hardy vines. $30 \xi$ each; $\$ 3.00$ doz.

Honeysuckle-Aurea Reticulata-Foliage beautifully variegated yellow and green, with yellowish white flowers.

Monthly Fragrant or Dutch-Blooms all Summer.

Common Woodbine-A strong, rapid grower; flowers very showy; red outside, buff within.

Scarlet Trumpet-A rapid grower, and produces scarlet inodorous flowers all summer.

Honeysuckle Plants, 25 e each; $\$ 2.50$ dozen.

By mail, $30 \notin$ each.

Kudzu Vine - A rapid growing vine, attaining, after once being established, a height of 50 feet in one season. Its foliage is large and furnishes dense shade; it bears small racemes of rosy-purple, pea-shaped, fragrant blossoms in August and

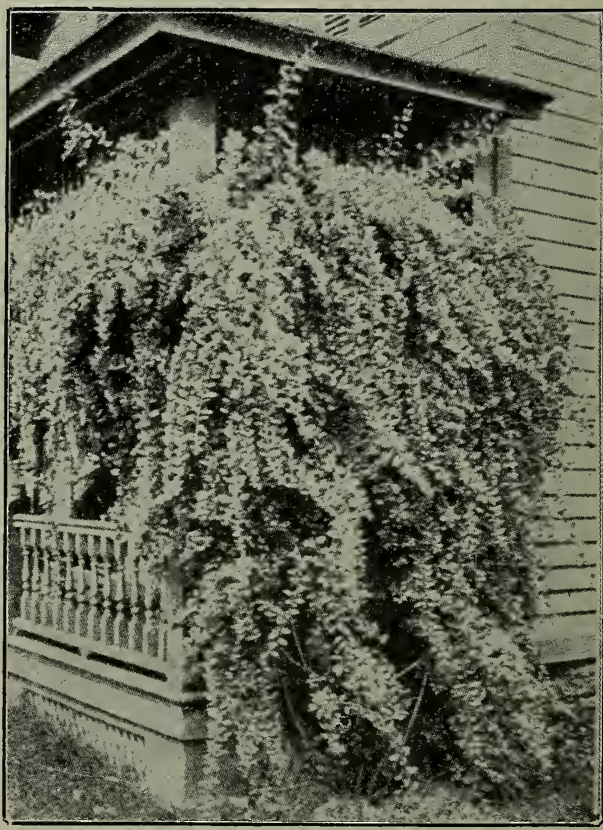
September. 25\& each; $\$ 2.50$ doz.; by mail, $30 \notin$ each. 


\section{HARDY CLIMBING PLANTS-Continued}

Wistaria Sinensis-The favorite variety, producing thousands of pendulous clusters of delicate violet blue blossoms, richly perfumed. 50k each; $\$ 5.00$ per doz.

Wistaria Sinensis Alba-Of similar habit to Sinensis, with pure white flowers. 50ć each; \$5.00 per doz. Wistarias can only be sent by Express or Freight.

\section{ORNAMENTAL GRASSES}

Erianthus Ravennae (Plume Grass) - Grows six to eight feet high and produces handsome plumes in fall.

Eulalia Gracillima (Japan Rush) - The most beautiful of all the Eulalias, with narrow, graceful foliage, entirely green without variegation, except that the mid-rib is of a silver sheen. Perfectly hardy, very valuable.

Eulalia Japonica Variegata-Leaves striped white and green longitudinally.

Eulalia Zebrina (Zebra Grass) - A peculiar veriegated grass, growing six feet high. The variegation is unlike that of any plant, being across the leaf in regular bands, dark green and light yellow alternating.

The dried blooms of all the Eulalias make beautiful winter ornaments.

25 ć each, $\$ 2.50$ per dozen.

\section{EVERGREEN TREES}

We offer the following which have been grown in ample space and transplanted and are in the best condition to plant for immediate effect.

\section{ARBOR VITAE-THUYA}

Thuya Occidentalis (American Arbor Vitae)- Well known screen and hedge plant.

2 to $3 \mathrm{ft}$., $75 \mathrm{cts} ; 3$ to $4 \mathrm{ft}$. $\$ 1.00 ; 5$ to $6 \mathrm{ft}$., $\$ 2.00$.

Thuya Occidentalis Columbia-Specimen plants. $4 \mathrm{ft} . \$ 5.00$

Thuya Occidentalis Globosa Nova-Very dwarf and compact, grows naturally into a rounded almost ball-like form ...................... 1.50 to 2.00

Thuya Occidentalis Wareana-A valuable species for cold climates, dense and shapely, medium height.

$\$ 2.50$ to $\$ 5.00$

Thuya Pyramidalis-Very shapely, suitable for tubs.

$\$ 2.00$ to $\$ 5.00$

Tsuga Canadensis (Hemlock Spruce) - A magnificent native tree that grows rapidly, and is very hardy. $1 \frac{1}{2}$ to

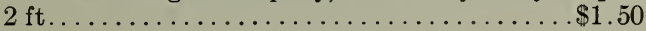
Specimen trees, 2 to $2 \frac{1}{2} \mathrm{ft}$., $\$ 2.50 ; 3 \mathrm{ft} \ldots \ldots \ldots . \$ 3.00$

Abies Balsamea (Balsam Fir) - A regular symmetrical tree assuming the cone shape when quite young. Leaves dark green, lighter beneath. 2 to $3 \mathrm{ft}$., $75 \mathrm{cts} ; 3$ to $4 \mathrm{ft} \ldots \ldots \ldots \ldots \ldots \ldots \ldots \ldots \ldots \ldots$ to $\$ 3.00$

Abies Bracyphylla-A magnificent Japanese fir, with erect stem regularly whorled horizontal branches. Specimen trees, 2 to $3 \mathrm{ft} \ldots \ldots \ldots \ldots \ldots \ldots 2.50$ to $\$ 3.00$

Abies Veitchii-A magnificent tree of splendid habit. The needles are dark green above and silvery white beneath ..................... $\$ 5.00$ to $\$ 8.00$

Juniperus, Sabina (Savin Juniper).-A thickly branched dwarf spreading shrub with dark green foliage; 2 to

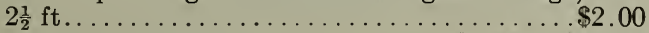
Specimen trees.............. $\$ 5.00$ to $\$ 10.00$

Juniperus, Sabina Tamaricifolia (Tamarax Leaved Savin)4 to $5 \mathrm{ft} \ldots \ldots \ldots \ldots \ldots \ldots \ldots \ldots . \ldots 3.00$ to $\$ 6.00$

Juniperus, Virginia Cannarti ........... \$5.00 to $\$ 7.00$

Juniperus, Virginia Glauca (Red Cedar) -Beautiful blue glaucous foliage. Specimen trees, 4 to $5 \mathrm{ft}$.

$\$ 2.00$ to $\$ 8.00$

Juniperus, Virginia, Shottei.-A distinct variety of pyramidal habit, with light green foliage, 2 to $3 \mathrm{ft} . \ldots 75 \phi$

Picea Excelsa (Norway Spruce)-A rapid vigorous growing tree, with dark green foliage. One of the most popular evergreen trees. 2 to $3 \mathrm{ft}$., 75 c; 3 to $4 \mathrm{ft}$., $\$ 1.00$; 4 to $5 \mathrm{ft} \ldots \ldots \ldots \ldots \ldots \ldots \ldots \ldots \ldots \ldots 1.50$ to $\$ 2.50$
Picea Excelsa Compacta-Very attractive, compact and distinct. Specimen trees.............\$4.00

Picea Excelsia Remonti-Dwarf compact variety. 1 to $2 \mathrm{ft} \ldots \ldots \ldots \ldots \ldots \ldots \ldots \ldots \ldots 1.50$ to $\$ 4.00$

Picea Orientalis-Habit compact and symmetrical, with short dark green needles. Specimen trees $\$ 2.50$ to5.00

Picea Pungens Glauca Kosteriana (Koster's Blue Spruce)The finest ornamental evergreen grown. The foliage is the purest blue. Specimen trees, 2 to $2 \frac{1}{2} \mathrm{ft}$., $\$ 2.00$ to $\$ 4.00 ; 3$ to $3 \frac{1}{2} \mathrm{ft}$., $\$ 5.00$ to $\$ 7.50 ; 4$ to $4 \frac{1}{2} \mathrm{ft} . . \$ 10.00$

Picea Pungens Glauca (Koster's Weeping Blue Spruce)Specimen trees, $2 \frac{1}{2}$ to $3 \mathrm{ft}$., $\$ 7.00 ; 4 \mathrm{ft}$., . . . $\$ 10.00$

Pinus Austriaca (Austrian Pine) - A tall tree, with spreading branches heavily plumed with long stiff needles,

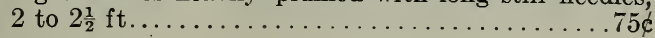

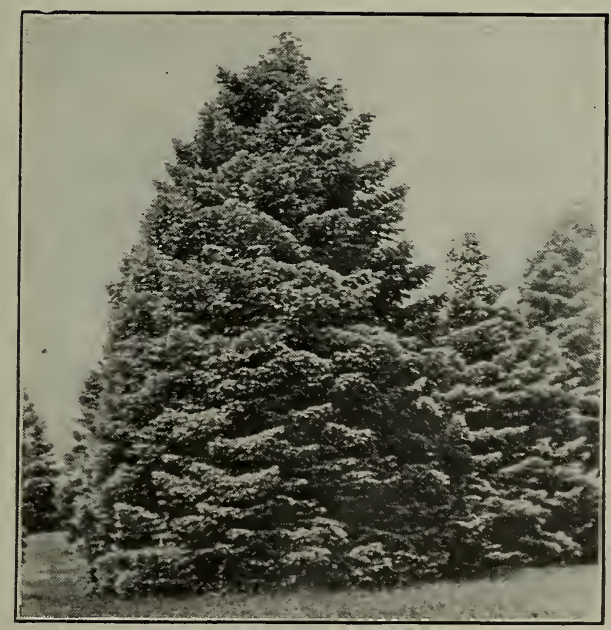

\section{Norway Spruce}

Pinus Mughus (Mugho Pine) - A unique alpine species; broader than its height, and sometimes almost prostrate. 10 to 12 in., $\$ 1.00 ; 18$ to 24 in., $\$ 1.50$ to $\$ 2.50$

Pinus Strobus (White Pine) - A beautiful ornamental tree, also used for shade and shelter belts. 2 to $3 \mathrm{ft} . \$ 1.00$

We, The J. Chas. McCullough Seed Co., give no warranty, express or implied, as to description, quality, productiveness or any matter of any seeds, bulbs, plants or trees we send out, and we will not be in any way responsible for the crop. If the purchaser does not accept the goods on these terms, they are at once to be returned and the amount paid will be refunded. If they are kept it will be taken as proof that they are satisfactory.-The J. Chas. McCullough Seed Co. 


\section{EVERGREEN TREES-Continued}

Pinus Sylvestris (Scotch Pine)-A strong grower, with spreading branches and short stiff needles. 2 to $3 \mathrm{ft}$., $75 \notin ; 3$ to $4 \mathrm{ft} \ldots \ldots \ldots \ldots \ldots \ldots \ldots \ldots \ldots 1.00$

Retinospora Filifera-A broad bushy tree, with dark green foliage in pendulous thread-like strings. 2 to $2 \frac{1}{2} \mathrm{ft}$., $\$ 2.00 ; 3 \frac{1}{2} \mathrm{ft} . \ldots \ldots \ldots \ldots \ldots \ldots \ldots \ldots \ldots 4.00$

Retinospora Pisifera-The slender branches are open and graceful. Foliage light green above, silvery beneath.

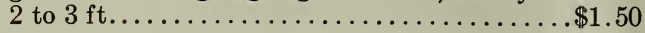

Retinospora Pisifera Aurea-Golden evergreen, light airy foliage. 2 to 3 feet................\$1.50 Specimen plants, $3 \mathrm{ft} ., \$ 3.50 ; 6 \mathrm{ft} ., \ldots \ldots \ldots \ldots \$ 6.00$

Retinospora Plumosa-Light green feathery foliage. It stands shearing well. $2 \mathrm{ft} \ldots \ldots \ldots \ldots \ldots \ldots . \$ 2.50$

Retinospora Plumosa Aurea-A dense small sized graceful tree. The young growth is a bright golden yellow. $1 \frac{1}{2}$ to $2 \mathrm{ft}$., $\$ 1.00 ; 2 \frac{1}{2}$ to $3 \mathrm{ft}$., $\$ 1.50$. Specimen plants, $3 \mathrm{ft} ., \$ 3.50 ; 5 \mathrm{ft} \ldots \ldots \ldots \ldots \ldots \ldots \ldots \ldots \ldots . \$ 5.00$

Retinospora Plumosa Aurea Globe-Shaped-Specimen plants.......................\$2.00 to $\$ 5.00$

Retinospora Aquarrosa Veitchii-Dense growth; soft beautiful silvery blue foliage, arranged in spirals. Specimen trees . . . . . . . . . . . . . . $\$ 1.50$ to $\$ 5.00$

\section{BOXWOOD TREES}

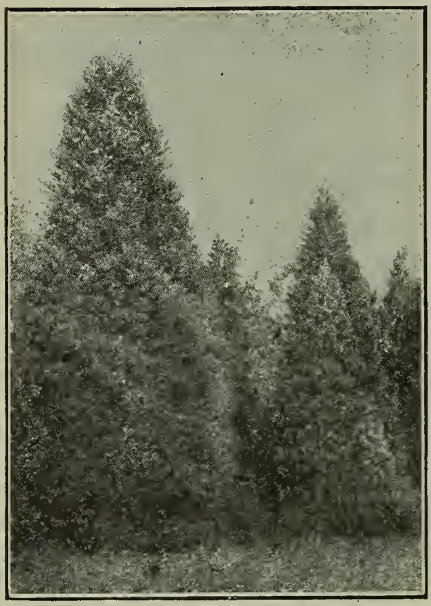

Evergreens.
Trimmed in Pyramidal, Globe Shaped and Standard, or Tree Form.

Pyramid Shaped. $-2 \frac{1}{2}$ feet high, $\$ 2.50$ each, $\$ 4.50$ pair.

3 feet high, 4.00 each, 7.00 pair.

4 feet high, 6.00 each, 11.00 pair.

5 feet high, 8.00 each, 15.00 pair.

Globe Shaped-1 $1 \frac{1}{2}$ feet high by $1 \frac{1}{2}$ feet in diameter, $\$ 5.00$ each

" " $2 \frac{1}{2}$ feet high by $2 \frac{1}{2}$ feet in diameter, 7.50 each.

3 feet high by 3 feet in diamater, 12.00 each.

Bush Shaped.-1 $1 \frac{1}{2}$ feet, $\$ 0.75$ each, $\$ 1.25$ pair.

" " 2 feet, 2.00 each, 3.50 pair.

$2 \frac{1}{2}$ feet, 3.00 each, 6.00 pair.

Standard or Tree Shaped-Diameter of crown, 18 to 21 in. $\$ 3.50$ to $\$ 5.00$ each " " " Diameter of crown, 21 to 24 in. $\$ 5.00$ to $\$ 7.50$ each " " " " " Diameter of crown, 30 inches, $\$ 7.50$ to $\$ 10.00$ each " " " Extra fine specimens, $\$ 12.00$ to $\$ 15.00$ each

Box Dwarf-Used principally for borders and edging, for which purpose it is the best plant in cultivation. 6 inches, $\$ 1.25$ per doz.; $\$ 8.00$ per 100 . Extra strong bushy plants, $\$ 1.50$ per doz.; $\$ 10.00$ per 100 .

\section{Fruit Trees, Small Fruits, Grape Vines, Etc.}

Select thrifty young trees in preference to old or very large ones; the roots are more tender and fibrous and they bear transplanting better and are more apt to live; they can also be more easily trimmed and shaped to any desired form, and in the course of a few years will usually outstrip the older ones in growth. If not prepared to plant when your stock arrives, "heel in" by digging a trench deep enough to admit all the roots and setting the trees therein,carefully pack the earth about the roots, taking up when required. Never leave the roots exposed to the sun and air.

\section{SENT BY EXPRESS OR FREIGHT AT EXPENSE OF PURCHASER}

\section{APPLES}

Standard

We can furnish all varieties usually catalogued, but the following list comprises the most desirable sorts:

Three years old, 5 to 7 feet high, $30 \notin$ each; $\$ 3.00$ dozen.

\section{Summer Varieties}

Early Harvest-Pale yellow, fine flavor, August.

Golden Sweet-Pale yellow, sweet and good; August.

Keswick Codlin-Large pale yellow, pleasant; August.

Oldenburg (Duchess of Oldenburg)-Large, striped over a greenish yellow ground.

Red Astrachan-Large, crimson, juicy, with rich sub-acid flavor; hardy. July.

Yellow Transparent-Pale yellow, good quality.

\section{Autumn Varieties}

Fall Pippin-Very large, yellow, rich, aromatic.

Gravenstein-Large, striped, fine quality; September and October.

Maiden's Blush-Large, beautiful, blush cheek.

Rambo-Yellow, streaked with red; October to December. Red Beitigheimer-Pale cream, covered with crimson.

\section{Winter Varities}

Baldwin-Large, dark red, productive.

Ben Davis-Large, handsome, striped; good quality.

Gano-Deep red, fine quality; good shipper and keeper.

Golden Russet-Medium, dull russet, crisp, juicy.

Grimes Golden Pippin-Medium to large, skin golden yellow, flesh crisp, tender, juicy, long keeper. 


\section{FRUIT TREES, GRAPE VINES, SMALL FRUITS, ETC.-Continued}

APPLES, WINTER VARIETIES-Continued

Jonathan-Medium, red and yellow, flesh tender, juicy and rich.

Northern Spy-Large, striped red; good keeper.

Rawle's Janet-Medium, yellow striped with red, rich, crisp and juicy; a long keeper.

Rome Beauty - Large, yellow shaded red, tender.

Smith's Cider-Medium, tender and juicy; sub-acid.

Wealthy-Large, round, skin smooth, splashed dark red; flesh white, tender, juicy, sub-acid.

White Pippin-Large, pale yellow, rich, sub-acid.

Wine Sap-Medium, deep red, rich, sub-acid.

\section{CRAB APPLES}

5 to 7 feet, 30 \& each; $\$ 3.00$ per dozen.

Hewes Crab for Cider-Best cider crab grown.

Yellow Siberian-Golden amber, with red blush in sun.

Hyslop-Deep crimson, very popular on account of its -large size, beauty and hardiness.

Transcendant-Skin yellow, striped with red.

\section{PEARS}

\section{Standard and Dwarf}

6 to 7 feet, first-class, 50 c each; $\$ 5.00$ dozen.

Bartlett-Large, clear, yellow, juicy. August.

Flemish Beauty-Large, juicy, rich and fine; September to October.

Howell-Large, yellow, splendid quality. September.

Kiefer's Hybrid-Large, rich color and good quality.

Lawrence-Yellow, thickly dotted, fine flavor.

Seckel-Small, yellowish brown, one of the best.

Sheldon-Large, round, russet-red. October.

Tyson-Large, yellow with brown cheek, sweet.

\section{QUINCES}

4 to 5 feet, $50 \notin$ each; $\$ 5.00$ per dozen.

Meech's Prolific-Fruit bright yellow; flesh very fragrant and tender. October.

Orange-Large, bright golden yellow, fine quality; flesh firm, cooks tender. October.

\section{PEACHES}

4 to 6 feet, 25 each; $\$ 2.50$ per dozen.

Champion-Creamy white with red cheeks, freestone, excellent qaulity; early in August.

Crawford's Early. Large yellow, of good quality, freestone early in September.

Crawford's Late-Large, yellow with red cheek, freestone; last of September.

Early Rivers-Large, creamy white, with pink cheeks; early in August.

Elberta-Large, yellow with red cheek, flesh yellow; firm, juicy, of high quality, very prolific; September.

Fitzgerald-Large, yellow suffused with red, flesh deep yellow, best quality, hardy and productive; early September.
Heath Cling-Large, flesh white, juicy and melting; October.

Mountain Rose-Large, handsome red cheek, flesh white, juicy; one of the best; August.

Old Mixon Cling-Large, yellow with red cheek; September.

Old Mixon Free.-Large, yellow with red cheek; September.

Smock's Free-Large, yellow, very productive; late September.

\section{CHERRIES}

\section{Heart and Bigarreau (Sweet)}

5 to 7 feet, first-class, $60 \notin$ each; $\$ 6.00$ per doz.

Allen-Large, nearly black, very mealy and firm, productive and excellent quality.

Black Tartarian-Very large, purplish black, juicy, rich, excellent, productive; last of June.

Governor Wood-Large, light red, juicy, rich, delicious. Three healthy and productive; June.

Napoleon-Large, pale yellow, firm, juicy, productive.

Rockport Bigarreau-Large, yellow, juicy and sweet.

Yellow Spanish-Large, pale yellow with light red cheek; late June.

\section{Duke and Morello (Sour)}

4 to 6 feet, first-class, 50 c each; $\$ 5.00$ per dozen.

Dyehouse-A very early and sure bearer; ripens a week before Early Richmond; fine quality; June.

Early Richmond-Medium, dark red, fine quality.

English Morello-Dark red, rich, acid, juicy and good.

May Duke-Large, red, an excellent variety.

Montmorency-Large, red, fine flavor; finest acid cherry.

Olivet-Large, red, tender, rich; sub-acid flavor.

\section{PLUMS}

\section{Standard}

On Plum Stock, 5 to 7 feet, 50 each; 5.00 per doz.

Abundance-Large, yellow with heavy bloom, good quality, very prolific.

Beauty of Naples-Medium size, green with purplish cheek, abundant bearer.

Burbank-The largest and best variety, color red, excellent quality, hardy and vigorous grower.

Damson-Small, oval fruit, purple, hardy, productive.

German Prune-Medium, oval fruit, purple, fine quality.

Green Gage-Small, delicious, very prolific, fine quality.

Lombard-Medium, red, juicy, hardy and productive.

Purple Egg-Rich purple, fine flavor, best market variety.

Red June-Large, red, fine quality; strong, vigorous grower. Finest extra early plum.

\section{MULBERRIES}

5 to 6 feet, 60 each; $\$ 6.00$ per dozen.

Downing's Everbearing-One of the most prolific varieties, bearing an abundance of large, black, sub-acid fruits, hardy; fruits about three months.

New American-An everbearing variety; large fruit of the finest flavor, hardy; fruits about three months.

PROMPT AND CAREFUL ATTENTION is given to all orders either large or small. Remember, we fill orders of any amount, but when ordering, if possible, make orders not less than 25 cents, as when orders are smaller than this it is generally at a loss to us. 


\section{GRAPE VINES, SMALL FRUITS, ETC.-Continued}

\section{GRAPE VINES \\ All Two-Year-OId Selected Stock. Black or Purple Grapes}

Campbell's Early-Bunch and berry large, glossy, black, sweet and juicy; fine quality. 25e each; $\$ 2.50$ doz. Concord-Large, black grape, hardy and productive; juicy and sweet. $10 \notin$ each; $\$ 1.00$ doz.

Early Ohio-Earliest black grape known; healthy and vigorous grower. $25 \dot{\phi}$ each; $\$ 2.50 \mathrm{doz}$.

Eaton-Bunch and berries very large, skin black and finest quality. $25 \mathrm{c}$ each; $\$ 2.50 \mathrm{doz}$.

*Ives' Seedling-Dark purple, sweet. $10 \notin$ each; $\$ 1.00 \mathrm{doz}$.

\section{Red Grapes}

Brighton-Bunch large, berries large, red, round, excellent flavor; one of the earliest. $15 \mathrm{c}$ each; $\$ 1.25 \mathrm{doz}$.

*Catawba-Berries large, round; when ripe a dark copper color; sweet, rich, musky flavor. $15 \notin$ each; $\$ 1.25 \mathrm{doz}$.

Delaware-Small, light red, thin skin, very juicy, sweet, sprightly, fine flavor. $15 \phi$ each; $\$ 1.50 \mathrm{doz}$.

\section{White or Yellow Grapes}

Niagara-Vine remarkably hardy and strong grower;bunches very large and compact; berries large, light greenish white, slightly ambered in the sun; skin thin but tough, and does not crack. $15 \dot{e}$ each; $\$ 1.25 \mathrm{doz}$.

Pocklington-A seedling of the Concord, resembling that variety in leaf, vine, habit of growth, hardiness and productiveness. Bunch and berry very large; attractive golden yellow color. $15 \notin$ each; $\$ 1.25 \mathrm{doz}$.

Varieties marked with a $*$ are best for arbors.

\section{BLACKBERRIES}

50 cents per dozen. $\$ 3.50$ per 100 except where noted.

Ancient Briton-Large fruit, stems loaded with good sized berries of fine quality; vigorous grower, hardy.

Early Harvest-Very prolific, choice variety.

Blower's (new) - Large, luscious berries, rich in quality and quantity. $75 \notin$ per doz.; $\$ 5.00$ per 100 .

Eldorado-Large fruit, borne in large clusters and ripen well together, fine quality, good keeper.

Kenoyer (new)-Early, berry large of good color, heavy yielder and good shipper. $10 \notin \mathrm{each} ; \$ 1.00 \mathrm{doz}$.

Mersereau (new)-Extremely hardy, berries sweet, rich,

melting and luscious without core. Good keeper and shipper. $75 \notin$ per doz.; $\$ 5.00$ per 100 .

Snyder-Medium size, sweet and juicy; extremely hardy and very productive.

\section{DEWBERRY}

Lucretia-One of the low-growing, trailing blackberries. In earliness, size and quality it equals any of the tallgrowing sorts. It has proved highly satisfactory wherever tried, and many say it is the best of all the blackberry family. $50 \notin$ per doz.; $\$ 3.00$ per 100

\section{CURRANTS}

\section{2 cents Each; $\$ 1.25$ per Dozen.}

Black Champion-Large bunch and berry, excellent quality, strong grower, very productive.

Cherry-Fruit large, bunch small, deep red, acid.

Fay's Prolific-Extra large stems and berries, color rich red, fine quality, very productive.

Pomona-Bright red, extra fine quality and enormously productive; strong, vigorous grower.
Red Dutch-An old favorite variety with large red berries. White Grape-Large, yellowish white, sweet, excellent quality and valuable for the table.

\section{RASPBERRIES}

50 cents per Dozen; $\$ 3.00$ per 100.

Brandywine-Large size, light crimson color, good quality and firm, vigorous and productive. One of the best, well-tested, large early berries for the North.

Cumberland-The largest black cap; a healthy, vigorous grower; very productive and of finest quality.

Cuthbert-Large, firm, deep rich crimson, of excellent quality, tall, strong, vigorous, perfectly hardy and very productive. Ripens medium to late.

Gregg-A large, black variety, fruit firm, of excellent quality and a good shipper.

\section{STRAWBERRIES}

All varieties offered in this list have perfect or bi-sexual blossoms, except those marked (P), which are destitute of stamens, and are termed pistillate or imperfect flowering varieties and must be planted near some perfect-flowering sort or they will produce litttle or no fruit.

Dip the plants in water as soon as received, and bury the roots in moist, shady ground till you are ready to set them out. Neglect for an hour or so is often fatal. 25 per dozen; $\$ 1.00$ per $100 ; \$ 7.50$ per 1,000 .

Brandywine-A fine, large, late, handsome, productive berry of excellent quality; regular conical form; dark, glossy red.

Bubach's No. 5 (P)-Large and uniform size, fine form and color; the leading market sort.

Cardinal (P)-This Strawberry surpasses all in size of plant and abundance of runners; fruit stalks tall and robust, bearing fruit well off the ground; color, beautiful cardinal red.

Clyde-Large, light scarlet color; conical shape; very productive, good quality.

Gandy-One of the best late varieties. Berries large, of fine form and excellent quality.

Glen Mary-Large to very large, sometimes flattened; sweet, rich, delightful.

Haverland $(\mathrm{P})$ - Very productive of medium to large, conical berries that are smooth, regular, mildly sub-acid.

Jessie-Berries large, handsome, dark red. The plant is vigorous, healthy, with strongly staminate blooms; a good pollenizer for imperfect-flowering sorts.

Nick Ohmer-A fine, fancy market berry and always superb for the table. A giant in size.

Senator Dunlap - Exceedingly vigorous. Fruit large, regular and attractive in form, deep red to the center. Firm in substance.

Warfield (P) - Great beauty, firmness, earliness, productiveness and vigor makes this berry most popular.

Wm. Belt-Berries very large, conical, bright red, of good flavor. The plant is strong, healthy, very fruitful. Season medium to late.

\section{GOOSEBERRIES}

Downings - Very large and fine quality. $\$ 2.00 \mathrm{doz}$.

Houghton-Medium size, very productive, $\$ 2.00 \mathrm{doz}$.

Smith's Improved-Large, thin skin, best for table use. $\$ 2.00 \mathrm{doz}$.

Industry-English sort, of very large size, hardy. $\$ 2.50$ doz.

DISTANCES FOR PLANTING_Grapes, rows 10 to 16 feet apart, 7 to 10 feet in rows. Blackberries, 6 to 7 feet apart 3 to 5 feet in rows. Currants, 4 feet apart each way. Gooseberries, 4 feet apart each way. Raspberries, rows 5 feet apart, 3 feet in rows. Strawberries, for field culture, rows 3 to $3 \frac{1}{2}$ feet apart, 1 to $1 \frac{1}{2}$ feet in rows; for Garden Culture, plant in beds 4 feet wide, 3 rows in each bed, plants 1 foot apart in rows. 


\section{Insecticides and Fungicides.}

Arsenate of Lead-The latest and best known insecticide for all leaf-eating insects. It adheres to the foilage for weeks, thus making frequent spraying unnecessary. 1 lb. jar, 25c; 2 lbs. 40c; 5 lbs., 75 c; 10 lbs. $\$ 1.25$; 20 lbs., \$2.40; 50 lbs., \$5.50; 100 lbs., \$10.50

Bordeaux Mixture (Paste)-A fungicide for curing and preventing black rot, mildew, blight, leaf curl, scab, or other fungoid diseases on fruits and plants, ready for use by simply adding water. $1 \mathrm{lb} ., 20$; 5 lbs., 60 c; $12 \frac{1}{2}$ lbs., $\$ 1.00 ; 25$ lbs., $\$ 2.00$.

Bordeaux Lead Arsenate Mixture (Paste)-An insecticide and fungicide combined in one, very effective product. Sticks well to the foliage, will not wash off by ordinary rains, and in this way the sprayer saves the expense in many instances of respraying. $1 \mathrm{lb}$, jar, 25c; 2 lbs., 40c; 5 lbs., 75 ć.

Fish Oil Soap-For destroying insects on plants, trees vines, etc., for washing down the bark of trees, grape vines, etc. $\frac{1}{2}-\mathrm{lb} .10 \dot{c} ; 1 \mathrm{lb} ., 15 \dot{c} ; 5 \mathrm{lbs} ., 70 \mathrm{c} ; 50 \mathrm{lbs}$. or over, $10 \mathrm{c} \mathrm{lb}$.

Hammond's Grape Dust-It is a preparation to kill the destructive mildew that strikes the grape vine, affecting leaves, fruit and stems in unfavorable seasons, also for like use on any other plant or trees affected with mould, mildew or rust mites. $10 c \mathrm{lb}$; $35 c 5$ lbs.; 60 é 10 lbs.; $\$ 5.50100$ lbs. By mail, 20ć lb.

Hellebore Powder White-For destruction of Slugs, Worms, Caterpillars, etc. $\frac{1}{2} \mathrm{lb} ., 15 \dot{c} ; 1 \mathrm{lb}$., 25 c.

Lime-Sulphur Solution-For Fall, Winter and early Spring spray. Destroys San Jose Scale, Peach Leaf Curl, Bud Moth, Apple Aphis, Blister Mite, any Scale insects or bark Lice. Lime and Sulphur Solution-If not exposed to air will remain in solution a long time; will not clog the spray pumps because it is free from sediment. 1 gallon will make 12 gallons spraying liquid. 1 qt., 25c; $\frac{1}{2}$ gal., 30 c; 1 gal., 50k; 5 gai., \$2.00; $\frac{1}{2}$ barrel, 25 gal., $\$ 6.25$; 1 barrel, 50 gal., $\$ 10.00$.

Paris Green-For insects which eat foliage. $\frac{1}{4} \mathrm{lb}$., 10ć; 1 lb., 30c; 5 lbs., \$1.25.

Persian Insect Powder-For Worms, Flies, Aphis, and almost all kinds of insects. $\frac{1}{4} \mathrm{lb}$., $15 \dot{c} ; 1 \mathrm{lb}$., 50c

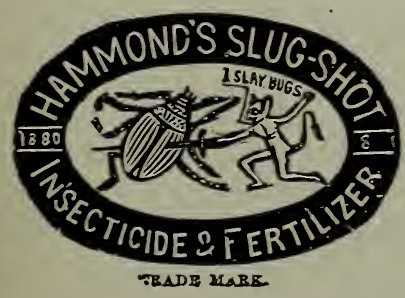

Slug Shot-Kilis caterpillars, currant, gooseberry and cabbage worms, potato, melon, cucumber and squash bugs, rose slugs, rose lice. $15 \notin \mathrm{l} \mathrm{lb}$. carton; 35 ć 5 lb. pkge; 60 é 10 lb. pkge. By mail, 10ć lb. extra.

\section{SCALECIDE-The Tree Saver Kills San Jose Scale.}

"Scalecide" will positively destroy all soft-bodied sucking insects, of whatever nature, on all kinds of fruit, shade and ornamental trees with less labor and expense than any known effective remedy.

50 gallon barrels, 50c per gallon $\ldots \ldots \ldots \ldots \ldots \$ 25.00$

30 " jacketed tins. .................. 15.00

10 " " cans....................... 6.00

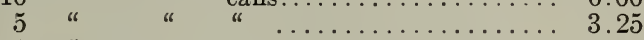

1 " cans.......................

Tobacco Dust-A sure remedy for Green Fly, Aphis, Fleas, Beetles, etc. Preventative for insects in the ground and around the roots. $1 \mathrm{lb} ., 10 \mathrm{c} ; 5 \mathrm{lbs} ., 25 \mathrm{c} ; 100 \mathrm{lbs}$., $\$ 3.00$.

Tobacco Stems-Used for fumigating plants to kill insects. Invaluable as a mulch for rose beds, lettuce beds, etc., where insects frequently do much injury to roots and foliage. Bale of about 400 lbs., $\$ 5.00$.

Tree Tanglefoot-For protecting trees against climbing insect pests in a simple, economical and effective way; put a band of tree tangle-foot, from 3 to 5 inches wide completely around the tree. A perfect safeguard against Gypsy, Brown-Tail and Tussock Moth, Canker Worms and Ants, and other creeping insects. 1 lb., 30k; 3 lbs., 85̌c; 10 lbs., \$2.65̃; 20 lbs., \$4.30; 25 lbs., \$5.95.

Weed Killer, Target Brand-A highly concentrated solution which dilutes one part to 50 parts of water. It is effective within 12 hours after application and one application will keep paths and roadways free from weeds for an entire season. 1 qt., 40c; 1 gal., $\$ 1.00$; 5 gal., $\$ 4.00 ; 10$ gal., $\$ 7.50$.

\section{Mehler's Handy Gardener}

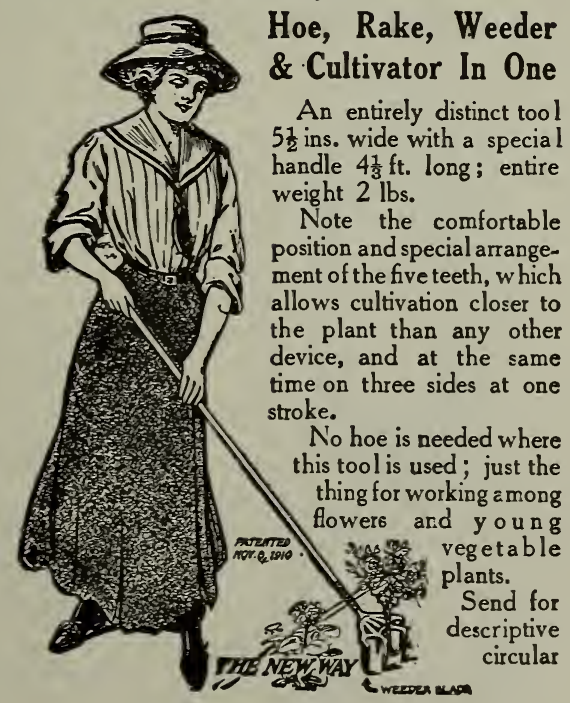

$7 \check{c}$ each.

Clover, and in fact all Leguminous Plants such as Cow Peas, Soja Beans, Vetch, etc., is a Blessing to Recuperate Wornout Land which needs Nitrogen Furnished by the Air. If your Land is Sour Correct by Sowing Lime. 


\section{Atomizers, Sprayers, Etc.}

\section{ACME ATOMIZER OR SPRAYER}

\section{For Spraying Paris Green and Other Insecticides on Potato Vines, Shrubs, Small Trees, Tobacco, House Plants, Live Stock and Poultry.}

A great labor saver on the farm and in every garden, barn, greenhouse, orchard and hennery. It will apply the Finest Possible Spray on any object desired and exterminate any kind of insect life. Weighs only one pound; can holds one and one-half pints and will cover 750 hills of potatoes and Kills the Old Bugs. Well and simply made, combined into the strongest possible shape, it cannot come apart, and easily cleans itself when turned upside down.

Prices: Heavy Tin, 40\& each; Heavy Tin with Galvanized Iron Reservoir, 50\& each.

\section{DRY POWDER BLOWER}

The Acme Powder Gun is the simplest tool ever made for applying poison to growing crops. It is entirely independent of water or plaster. No poison is left about the field to kill stock. It requires no base of supplies; all you need to carry is a can of dry insecticide and the gun. Without stooping - the elbow does it-it applies any powdered poison on any plant in any desired quantity, any time of the day. The elbow may be detached if desired. This tool is well made of the best material, and is thoroughly guaranteed. The bellows' sides are painted a bright vermillion and the handles finished bright. The leather is a fine russet. We also furnish a spreader for distributing the blast. Price, $\$ 1.00$.

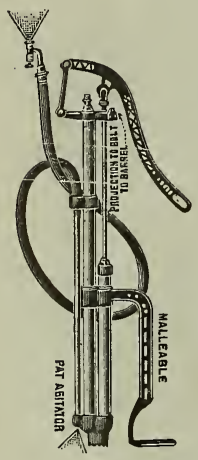

\section{LEVER BUCKET BRASS SPRAY PUMP}

It has all the advantages of the ordinary barrel pump and bucket pump combined. Is made of brass with ball valves; handle and foot rests are malleable iron. With agitator, complete with hose and graduating vermorel fine, coarse spray and solid stream nozzle................. $\$ 3.50$

\section{LITTLE GIANT BRASS SPRAY PUMP}

Is provided with a large air chamber. With agitator, complete with hose and Imperial combination, fine coarse, spray and solid stream nozzle, with malleable foot rest. . . . . . . . . . $\$ 2.25$

\section{RED STAR AIR SPRAYER}

Compressed air hand sprayer. Enables the operator to spray with one-half the labor the ordinary sprayer requires. Throws a fine mist and can be used to advantage in applying insecticides, etc. One quart size, each, 75 .
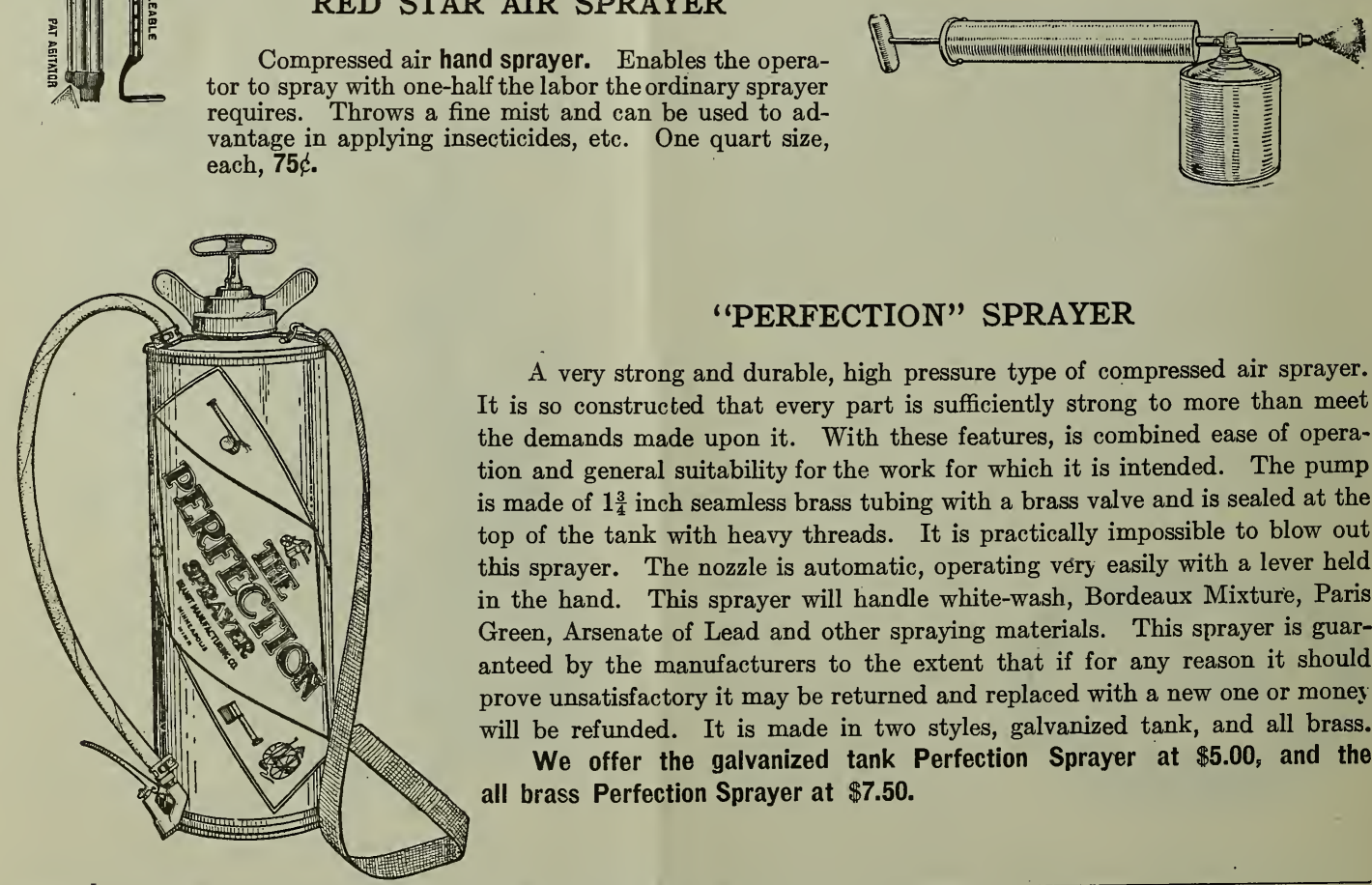

\section{"PERFECTION" SPRAYER}

A very strong and durable, high pressure type of compressed air sprayer. It is so constructed that every part is sufficiently strong to more than meet the demands made upon it. With these features, is combined ease of operation and general suitability for the work for which it is intended. The pump is made of $1 \frac{3}{4}$ inch seamless brass tubing with a brass valve and is sealed at the top of the tank with heavy threads. It is practically impossible to blow out this sprayer. The nozzle is automatic, operating verry easily with a lever held in the hand. This sprayer will handle white-wash, Bordeaux Mixture, Paris Green, Arsenate of Lead and other spraying materials. This sprayer is guaranteed by the manufacturers to the extent that if for any reason it should prove unsatisfactory it may be returned and replaced with a new one or money will be refunded. It is made in two styles, galvanized tank, and all brass.

We offer the galvanized tank Perfection Sprayer at $\$ 5.00$, and the all brass Perfection Sprayer at $\$ 7.50$. 


\section{SPRAYING PUMPS AND APPLIANCES-Continued.}

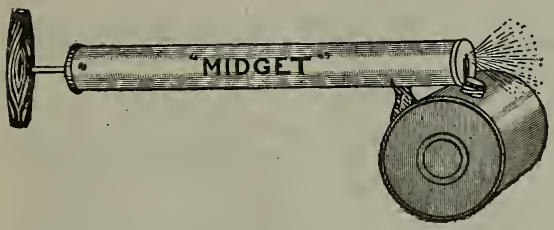

\section{THE “MIDGET" SPRAYER}

A new size made to fill the need for small sprayer for household requirements. It is made of a good weight of tin, the tank is $3 \mathrm{in.} \mathrm{in}$ diameter by 3 in. in length. Holds one pint; is 14 in. long over all, has $\frac{1}{4}$ in. pump rod fitted with anhydrous leather and our special metal expanders. Price, 25\& each.

\section{"MODOC" BUCKET PUMP}

This pump is all brass except the foot piece and handle. The cylinder, or barrel, is very large and is made of heavy seamless brass tubing; into this is put.the plunger (which is also made of seamless brass tubing), thereby largely increasing the pump's capacity. The plunger is hollow, thus forming an air chamber which insures a steady flow of liquid. The valves are bronze balls. The plunger packing is cotton wick and can quickly be changed when necessary. The foot piece holds the pump firmly in the bucket or pail in just the proper position for work. The pump is equipped with 3 -ft. $\frac{1}{2}$-inch spray hose attached with clamps.

Price.

\section{BAMBOO BRASS LINED SPRAY POLES}

$12 \mathrm{ft}$. lengths.

$10 \mathrm{ft}$. lengths

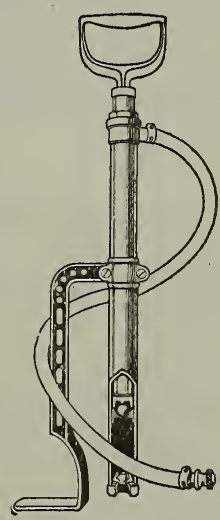

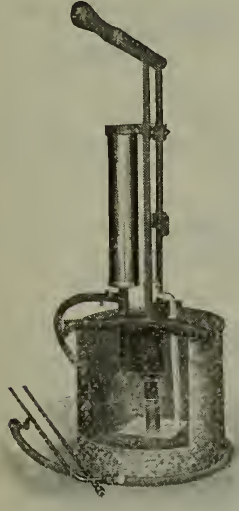

No. 1 Paragon Sprayer

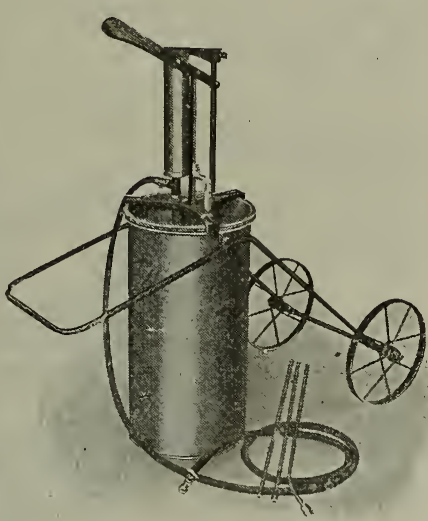

No. 3 Paragon Sprayer

\section{PARAGON SPRAYER}

For White Washing, Water Painting, Disinfecting, Spraying Trees, Vines and many other purposes.

This sprayer is strongly constructed and can be easily operated by one man. The strainer cannot clog because the agitator passes over openings in it with each stroke of the pump, brushing off any dirt or grit that may have a tendency to choke it. The agitator also keeps the liquid thoroughly stirred while using sprayer. Suitable for spraying insecticides and fungicides on trees, shrubs and vines as well as the application of whitewash and cold water paints. The best whitewash pump manufactured.

No. 0.-3 gallons, 4 feet rubber hose, 3 feet extension pipe.

No. 1. -5 gallons, with 5 feet rubber hose, 5 feet extension pipe and 2 spray nozzles $\$ 10.00$

No. 3.-12 gallons, mounted on a two wheel steel frame, 10 feet of rubber hose, $7 \frac{1}{2}$ feet extension pipe, 2 spray nozzles.

No. 5.-All brass, mounted on a 50 gallon heavy oak barrel. This pump is fitted with extra large air chamber and will sustain a pressure of $300 \mathrm{lbs}$, and throws a uniform and continuous spray. Fitted with 25 feet rubber hose, $7 \frac{1}{2}$ feet extension pipe, 1 spray nozzle, and triple spray nozzle $\$ 25.00$ 


\section{WHEN TO SPRAY AND WHAT TO USE}

\begin{tabular}{|c|c|c|c|c|}
\hline PLANT & 1st Application & 2nd Application & 3rd Application & 4th Application \\
\hline $\begin{array}{l}\text { A p p l e-(C a n k e r } \\
\text { worm, codling moth, } \\
\text { bud moth, scab.) }\end{array}$ & $\begin{array}{l}\text { Spray before buds } \\
\text { start, using c o p per } \\
\text { sulphate solution. }\end{array}$ & $\begin{array}{l}\text { After the blossoms } \\
\text { have formed, but be- } \\
\text { fore they open, Bor- } \\
\text { deaux and Paris green } \\
\text { or Fish Oil Soap.* }\end{array}$ & $\begin{array}{l}\text { Within a week after } \\
\text { blossoms have fallen, } \\
\text { Bordeaux and Paris } \\
\text { green, or Fish Oil } \\
\text { Soap. }\end{array}$ & $\begin{array}{l}10 \text { to } 14 \text { days later, } \\
\text { repeat. }\end{array}$ \\
\hline Cabbage-(Worms, & $\begin{array}{l}\text { When blossoms ap- } \\
\text { pear, spray with Bor- } \\
\text { deaux. } \\
\text { When worms first }\end{array}$ & If worms or aphides are & $\begin{array}{l}10 \text { to } 14 \text { days later, } \\
\text { weak copper sulphate } \\
\text { solution. } \\
\text { If aphides persist, or if }\end{array}$ & $\begin{array}{l}\text { Repeat last, if neces- } \\
\text { sary. } \\
\text { After heads form, use }\end{array}$ \\
\hline
\end{tabular}

aphis.) appear, Slug Shot, present, repeat if plants worms reappear, use saltpetre for worms, teakerosene emulsion, or are not heading, using kerosene emulsion, if spoonful to gallon water, Paris Green. emulsion for aphis. plants are not heading. emulsion for aphides.

Cherry-(Rot, aphis, Before buds start, use When fruit has set, 10 to 12 days later, 10 to 12 days later, curculio and slug.) coppersulphate solution. Bordeaux and Paris if signs of rot appear, copper sulphate soluFor aphis, kerosene green.* emulsion.

repeat.

tion, weak.

Currant-(Worms, As soon as worms are If they reappear, re- If worms still mildew.) seen, Paris green, Slug peat, adding Grape trouble, pyrethrum, or Shot or Hellebore. mildew. $\dagger$

Gooseberry-(Mil- As leaves open, Bor- In 10 to 14 days re- 10 to 14 days later, 10 to 14 days later, dew, worms.) deaux, Paris green, peat with both. $\quad$ sulphide of potassium repeat, if necessary. Slug Shot or Hellebore. on English varieties.

Grape-(Flea-beetle, Before buds burst, When first leaves are As soon as fruit has 10 to 14 days later, fungous diseases.) copper sulphate solution half grown, Grape Dust, set, repeat.* and Paris Green. Bordeaux or Paris green.

Peach, Apricot-Before buds swell, As soon as fruit has 10 to 12 days later, 10 to 12 days later, (Leafcurl, curculio, copper sulphate solu- set, Bordeaux and Paris repeat. mildew and rot.) tion.

green, or Fish Oil Soap.*

Pear-(Leaf blight, Before buds start, Within a week after 10 to 12 days later, 10 to 16 days later, scab,psylla and cod-copper sulphatesolution. blossoms fall, Bordeaux repeat. ling moth.) and Paris green, or Fish Oil Soap.

P I u m-(Black knot, As buds start, copper When fruit has set, 10 to 12 days later, rot and all fungous sulphate solution. Cut Bordeaux and Paris repeat. diseases, curculio.) out knot and burn. green, or Fish Oil Soap.*

Potato-(Beetles, For scab, soak seed in When beetles or their. Repeat whenever When blight of the scab, blight.) corrosive sublimate solu-larvae a p pear, Paris necessary. tion (2 oz. in 16 gallons green or Slug Shot. of water for 90 minutes.)

Quince-Leaf and Before buds start, When fruit has set, 10 to 12 days later, fruit spot rot.) coppersulphatesolution. Bordeaux and Paris repeat. green, or Fish Oil Soap.*

Raspberry, Black - Cut out badly dis- When new canes are 10 to 14 days later, crop is gathnose, rust.) copper sulphate solution Bordeaux mixture. solution. before growth starts.

Strawberry-(Rust). $\quad$ Just before blossoms - When fruit has set, As soon as berries are open, Bordeaux and Bordeaux, ${ }^{*}$ or weak harvested, Bordeaux Paris green. copper sulphate solu-if to be kept longer.

Tobacco-(Worms). Paris green.

Tomato-(Rot and When first fruits have blight, worms.) set, Bordeaux.

Spray at intervals.

If disease appears, re- If necessary, spray peat* or use weak cop- with weak copper sulper sulphate solution. phate solution. tion.

Vines-Cucumber Slug Shot or Tobacco Repeat at intervals. and Melon. Dust.

Bordeaux.

10 to 20 days later, Bordeaux. leaves is accompanied by rot of the tubers, Bordeaux.

10 to 20 days later, Bordeaux.

Explanation.-Whenever an asterisk $\left(^{*}\right)$ is used, it cautions against spraying with poisons while the plants are in blossom; a dagger $(\dagger)$ indicates that there is danger of making an application within 3 weeks of the time the fruit is to be used as food. While the number of applications recommended will be found desirable, in seasons when the fungi are less troublesome a smaller number may of ten suffice.

\section{BORDEAUX MIXTURE}

Copper sulphate, 4 lbs.; Quick lime, 4 lbs.; Paris green (for leaf eating insects), 4 oz.; Water (one barrel), 40-50 galș.

To prevent potato rot, $6 \mathrm{lbs}$. of copper sulphate is used instead of 4 .

\section{- F OR M ULAS KEROSENE EMULSION}

For sucking insects.

Kerosene (coal oil), 2 gals.; Rain water, 1 gal.; Soap $\frac{1}{2} \mathrm{lb}$. To be diluted before use with 9 parts of water.

\section{PARIS GREEN AND WATER}

For insects which eat foliage. Paris green, $1 \mathrm{lb}$; Lime (fresh), $1 \mathrm{lb}$.; Water 200 gals. 


\section{LAWN REQUISITES.}

\section{GENUINE PHILADELPHIA LAWN MOWER}

The Philadelphia Lawn Mower has stood the test for years, and is still acknowledged to be one of the best and a strictly High Grade Mower.

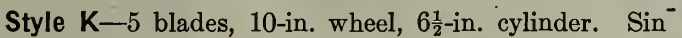
gle Pinion, geared on both sides. The greatest diameter of cylinder with five blades, insures fine cut, and with its large driving wheels, is light running.

14 -in., \$6.25; 16-in., \$7.00; 18-in., \$7.50; 20 in., \$8.25.

Style C-4 blades, $8 \frac{1}{2}$-in. wheel, $5 \frac{1}{4}$-in. cylinder. This style medium high wheel is to supply a demand for a mower, which has real merits, and is light running, durable and easy to handle.

14 -in., \$5.25; 16-in., \$5.75; 18-in., \$6.50; 20-in., $\$ 7.25$.

Style M. -3 blades, 7-in. wheel, $5 \frac{1}{4}$-in. solid cylinder, with blades bolted on. This is the original Philadelphia 1870 pattern mower, and for general purposes is very popular, adapted for rough as well as smooth lawns.

14 -in., $\$ 5.25 ; 16$-in., $\$ 5.75 ; 18$-in., $\$ 6.50 ; 20$-in., $\$ 7.25$.

Style E-Width of cut, 21 inches. Has high, 10-in. driving wheel, 4 blades, cylinder $6 \frac{1}{2}$ inches. Unlike all other mowers, the driving wheel and cylinder can be removed leaving a solid frame.

$$
\text { 21-in., } \$ 10.00 \text {. }
$$

\section{THE “CHIEF" HORSE LAWN MOWER}

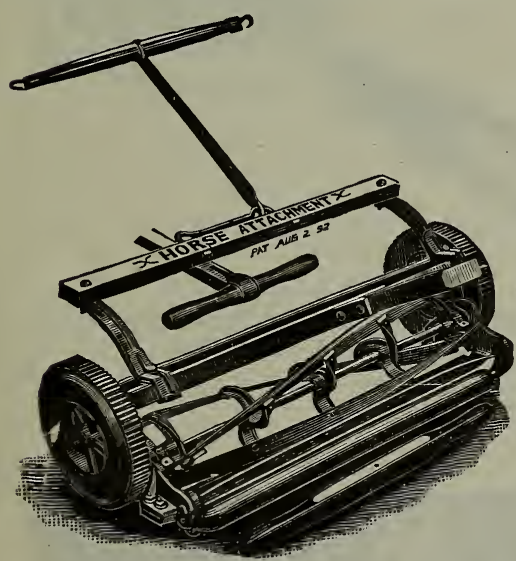

Can

be

Operated

Readily

by

Hand.

30 -inch cut.

10-inch Trac-

tion Wheels.

This Mower is used in our principal parks and cemeteries. The draft with the horse is the same as when operated with handle. Postively no tipping up with rear of the Mower.

Price, complete, $\$ 17.00$.

We can also supply the Philadelphia Horse Lawn Mowers. Prices on application.

\section{THE NEW AND MONARCH LAWN MOWERS}

14 -inch............................ \$2.50

16 -inch......................... 3.00

\section{DUNHAM ROLLER BEARING LAWN ROLLER}

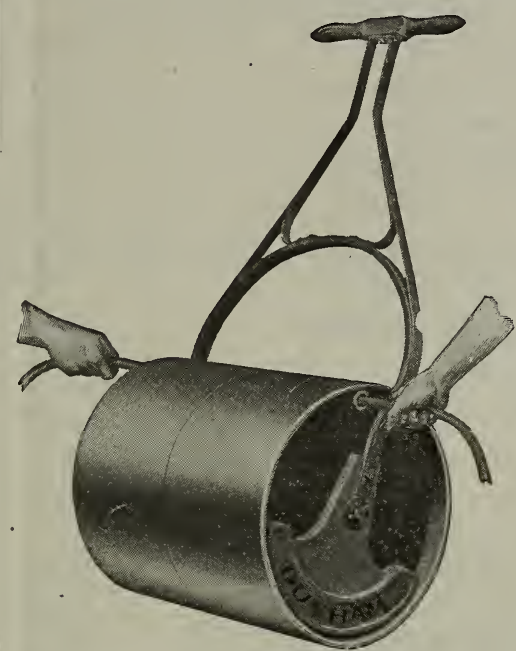

The Dunham Two Section "Water-Weight" Roller with counter-balancing handle weights
If you wish a fine lawn, you must use aLawn Roller. In no other manner can a smooth, compact surface b e m a i ntained. It packs the soil, thus retaining the moisture throughout the season, en a b ling y o ung and tender grass to secure the n e c e s s a ry nourishment.

Du n h m Lawn Rollers have automobile roller bearing axles and are easier to operate than any other. The only Lawn Roller made with roller bearings, and cost no more than the ordinary rollers.

Dunham Water Weight Rollers are electric weldedno rivets are used-the drum cannot possibly leak.

One- or two-section "Water Weight" Rollers, without counter-balancing handle-weights.

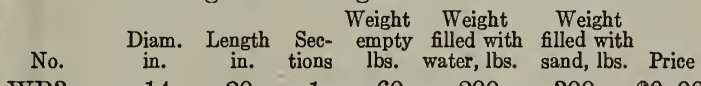

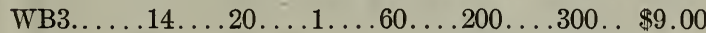

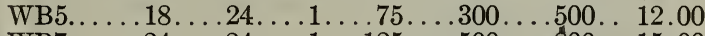

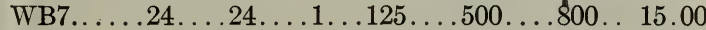

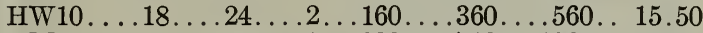
HW12 . . .24 . . .32 . . 2 .230 . . .710 . 1060 . 20.40

Dunham Roller Bearing Lawn Roller-The rollers are smooth on the face, and finished in aluminum. The outer edges are rounded to avoid cutting the lawn.

No. 401-2 Section. 16 inches long and 15 inches in diameter, weight $150 \mathrm{lbs} \ldots \ldots \ldots \ldots \ldots \ldots \ldots \$ 7.50$

No. 404-2 Section. 20 inches long and 20 inches in diameter, weight $250 \mathrm{lbs} . \ldots \ldots \ldots \ldots \ldots \ldots \ldots 12.00$

\section{GRASS CATCHER}

Fits any Lawn Mower. Gathers all the grass. Leaves the lawn smooth and velvety. It can be adjusted to any machine in a moment. The Catcher is made of heavy Duck. In ordering give the size of mower on which you intend to use the catcher. $75 \notin$ each.

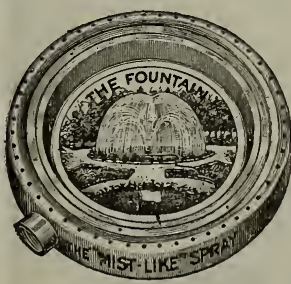

BRASS FOUNTAIN SPRINKLER

Very simple in construction. Cannot rust or get out of order. Will not injure the lawn. Requires only ordinary pressure of water. Price 75 c each. 


\section{Horticultural Tools and Sundries.}

Blue Grass Stripper, is well made and nicely painted, a man can strip 20 bushels of seed per day with it; weighs 4 pounds. . . . . . . . . . $\$ 1.50$

Dibbles for transplanting plants........... $\quad .50$

Grass Trimmer-Fisk \& Jay. . . . . . . . . . . . 1.25

Guns, Insect Powder-Defender.............. . $\quad .10$

" " Tornado............. .20

Hoes-Standard Socket Garden.............. $\quad .40$

“ Ladies' Light Garden.... . . . . . . . . . . . . $\quad .30$

" Onion, with two prongs.............. . 30

“ Mehler's Handy. . . . . . . . . . . . . . . . 1.00

Hyacinth Glasses-Single, assorted colors ........ . $\quad .20$

Knives-Pruning..............50\& to 1.50

" Budding...............50 to 1.50

Labels- - For pots, painted.

$4 \times 5 / 8$-inch, per $100,15 \notin \ldots \ldots$ per $1,000 \ldots \ldots \$ 1.00$

$5 \times 5 / 8$-inch, per $100,15 \notin \ldots \ldots$ per $1,000 \ldots \ldots 1.15$

$6 \times 5 / 8$-inch, per $100,20 \notin \ldots \ldots$ per $1,000 \ldots \ldots 1.25$

$8 \times 3 / 4$-inch, per $100,30 \notin \ldots \ldots$ per $1,000 \ldots \ldots 2.00$

Each.

Pruning Shears-Hand .............50 to $\$ 1.00$

Pruning Saws-Double Edge, 16 inch......... .60

" " " 18 inch......... .75

Potato Hooks -4 tine. . . . . . . . . . . . . .

Putty Bulbs-Used for setting glass with liquid

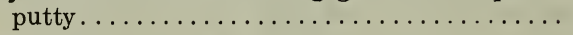

Raffia-For tying plants, per $\mathrm{lb} \ldots \ldots \ldots \ldots \ldots$.

Raffia Colored-For making baskets and fancy work in following colors; Black, Blue, Brown, Green, Orange, Pink, Red and Yellow. 2 oz., 10ф; $1 \mathrm{lb} ., 60 \phi$. If sent by mail 10غ per pound extra.

Reeds (Rattan)-For basket making, etc.

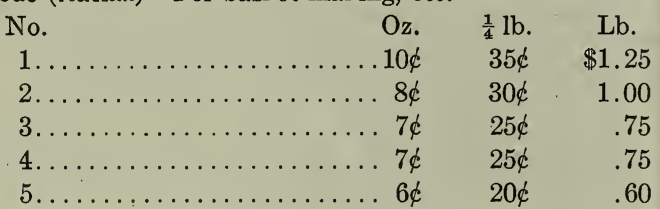

If sent by mail add $2 \phi$ per oz.; $5 \phi$ for $\frac{1}{4} \mathrm{lb}$; $15 \phi$ for lb.,

for postage.

Rakes-Steel Garden, 8 tooth............. $\$ 0.30$

" $"$ " 10 " $\quad \ldots \ldots \ldots \ldots \ldots \ldots$

" $"$ " $\quad 12{ }^{*}$ " $\ldots \ldots \ldots \ldots \ldots \ldots$

" « « 14 "

" Lawn, Wire 30 " $\quad \ldots \ldots \ldots \ldots \ldots \ldots$

" "Wooden $20 "$ " .............

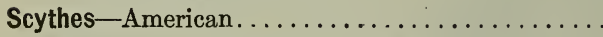

" " Weed or bush.............

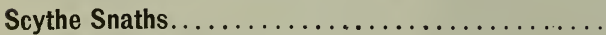

Scythe Stones, Flat, $5 \notin$; Round.............

Seed Tryers-Steel-pointed, pocket, nickel-plated

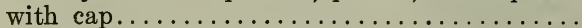

Seed Tryers-Large. For sampling Orchard Grass, Blue Grass, Coffee, etc.
Sprinklers-Scollay's Standard Rubber........ . $\$ 1.00$ " " Small size.............. .50

Shears-Hand, Grass or Border. . . . . ....... $\quad .50$

Thistle or Dock Cutters................ . $50 \notin$ to $\quad .60$

Trowels-Garden, English..............

American..............

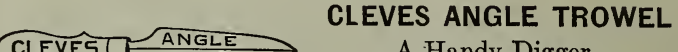

A Handy Digger.

This Trowel is one solid piece

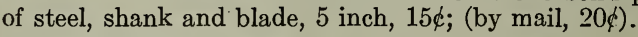

\section{HAZLETINE'S \\ HAND \\ WEEDER}

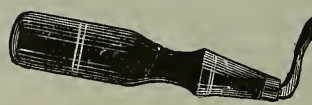

For weeding Onions, Strawberries, etc. Price $25 \phi$; (by mail, 30ф).

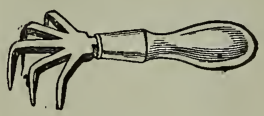

\section{EXCELSIOR HAND WEEDER}

Excellent for use in flower gardens, price 15 ; (by mail, 20ф).

\section{MAGIC COMBINED WEEDER AND HOE.}

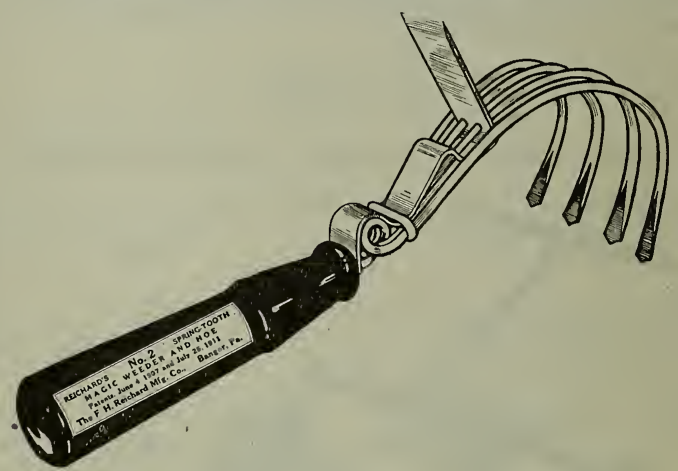

Fingers of tempered steel. The hoe is useful in loosening hard ground. 35 $\dot{\text {; }}$ (postage $5 \dot{\phi}$ each, extra.)

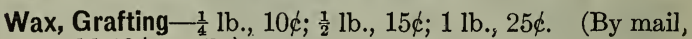
add $10 \notin$ per lb.)

TWO

Layers

of

Glass

Instead

of

ONE.

This new invention for expediating the growth of

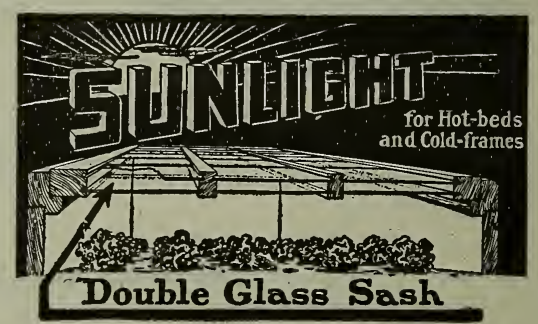
plants in

cold-frames or hot-beds is revolutionizing the business throughout the country. Every grower should have the SUNLIGHT DOUBLE GLASS SASH. Giving the beds all the light all the time and keeping them warm at night, Sunlight Sash produce the earliest, strongest and best plants, and the resulting crops are the best on the market and the most profitable. Write to-day for catalog.

$3 \times 6$ sash, painted 2 coats, no glass. Each $\$ 2.75$.

The new Planet, Jr., Hill Dropping Drill is the Most Complete Machine in its line ever offered. 


\section{MISCELLANEOUS.}

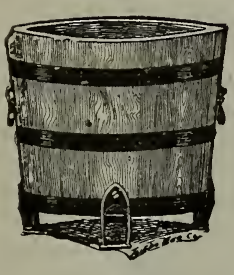

\section{AMERICAN PLANT TUBS}

An excellent new tub, cheap, neat and durable. Made from $\frac{3}{4}$ inch Cypress, with iron handles, 3 iron hoops and 2 coats of green paint.

No. 1. $\quad 11 \frac{1}{2}$ inches diameter, $11 \frac{1}{2}$ inches high $\ldots \ldots \ldots \ldots \ldots \ldots \ldots \ldots \ldots \ldots \ldots \ldots \ldots 1.00$

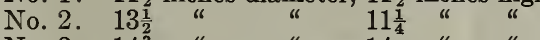

No. 3. $14 \frac{3}{4}$ " " 14 "

No. 4.716 "

No. 5. 19

No. 6.22

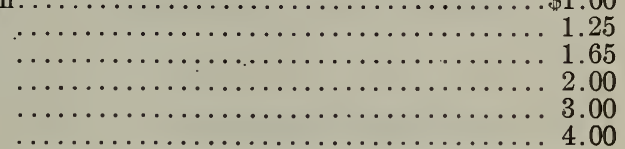

\section{STANDARD FLOWER POTS AND SAUCERS}

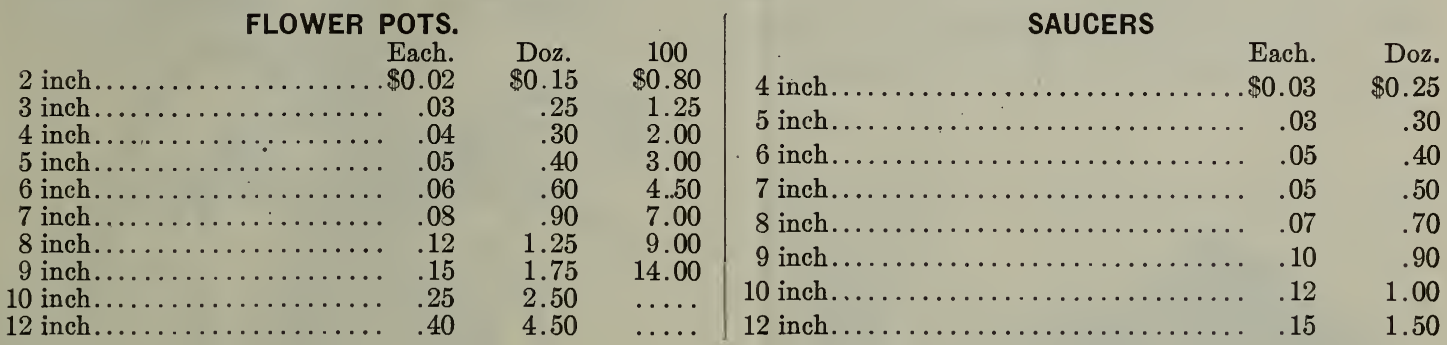

\section{FIBROTTA SAUCERS}

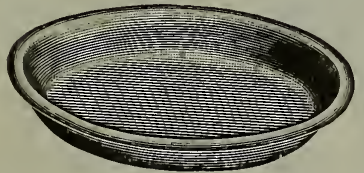

Fibrotta Saucers

Made of Indurated Fibre; no moisture goes through to injure table, floor or carpet, light and not easily broken; far cheaper in the end and better every way than earthen ware.

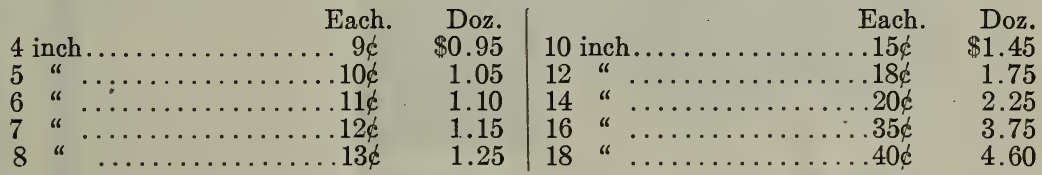

\section{FIBROTTA ROLLING STANDS}

For heavy plants and palms; will not soak or rust. Casters have ball bearings and have hardwood rollers. Rolling stands all have heavy deep saucers and will carry all the weight usually put in large pots for Palms, Rubber Plants.

12 inches diameter, 3 Casters. . . . . $\$ 0.60 \mid 18$ inches diameter, 4 Casters . . . . .\$1.00

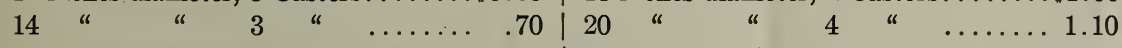

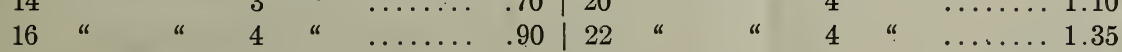

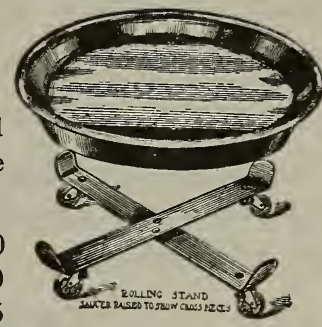

Fibrotta Rolling Stand

\section{CLIPPER SEED AND GRAIN MILLS}

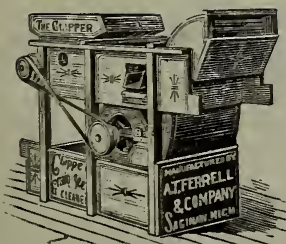

These mills are especially adapted for cleaning grain, clover and timothy seed. No. 1 , for grain and clover, $\$ 20.00$. Descriptive circulars and prices for larger sizes for either hand or power, sent on application.

\section{MOSHER BAG HOLDER}

Best on the market. With stand. Price $\$ 3.50$.

\section{THE DETROIT GRAIN BAG HOLDER}

Saves More Time, More Labor and More Money for the farmer in proportion to its cost than any implement ever invented for his use.

It has no hooks to tear the bag.

It is not necessary to remove it to sack down.

It is easily attached to the bag and will not get out of order.

It is perfect in its adjustment.

No one who handles grain can afford to be without it.

Price, 25\& each. $\$ 2.50$ dozen. 


\section{SPECIALTIES.}

\section{THE BIRD LOVERS}

The desire to show a few designs of our quaint and charming little bird hutlets and houses, which make ideal bird homes to attract the birds near one's residence. They are as practical and equally as comfortable and beautiful as the human habitation.

The Department of Biology of all governments are at present promoting the protection and propagation of their native birds. The intelligent citizens and home-lovers should help in this good and benefiting cause by erecting harbors and nesting places for their feathered friends and neighbors:

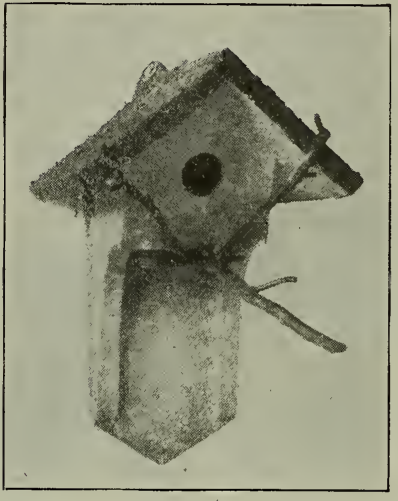

Wren Hutlet

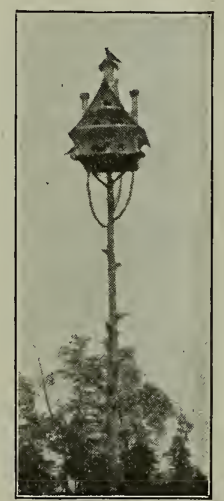

Martins

Martins one hour after erecting

\section{BIRD HOUSES}

These houses are constructed of a tinted stucco, which is indescructible and will last a lifetime. Instructions for placing on each hut.

\section{PRICE LIST HUTS AND CABINS}

Each.

Wren Hutlet.....................\$ 1.25

Chickadee Hutlet. . . . . . . . . . . . . 1.25

Bluebird Hut...................... 1.50

Titmouse....................... 1.50

Bark Hut. . . . . . . . . . . . . . . . . . . . . . . . .

Woodpecker and Flicker Hut............ 1.50

Martin Houses...............\$3.00 to 25.00

Squirrel Cabins.............. 5.00 to 10.00

Prices for Log Cabins and Summer Houses, Etc., on request.

\section{JARDINIER AND WINDOW BOXES}

We carry a full line of Jardiniers, Fern Dishes, Window Boxes, etc., made up in Antique Green, Mat Green, Ivory and other effects. Beautifully designed and colored; also Pedestals for Jardiniers. Call and see our assortment..

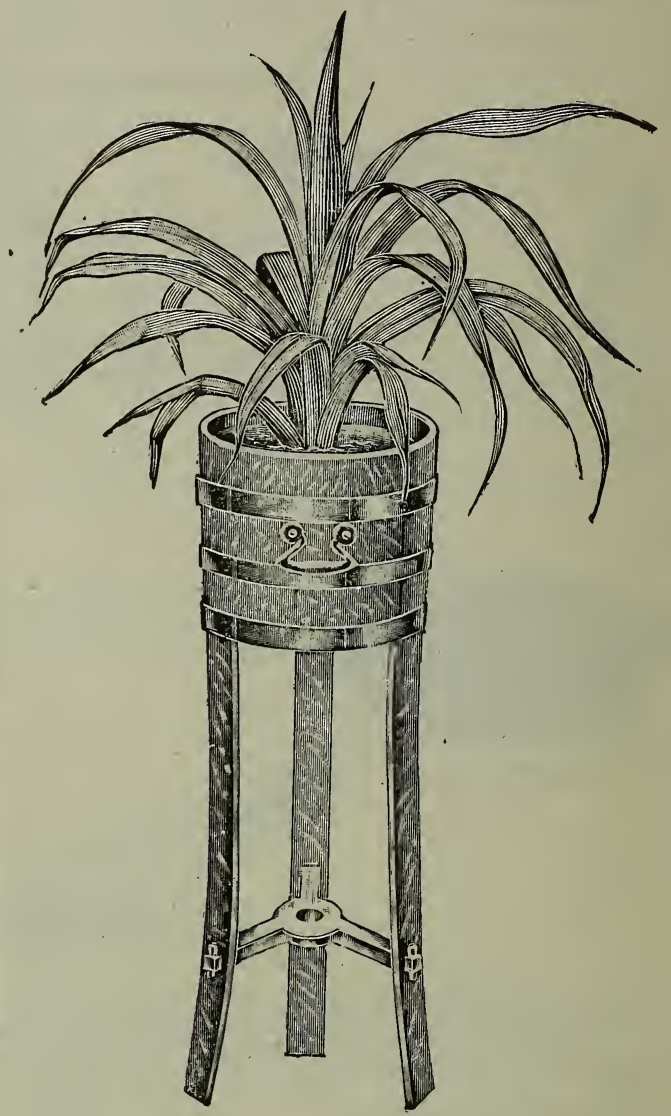

\section{JARDINIER PLANT, TUB AND STAND}

Is a work of art that would adorn the Palace of a King. They are made from quartered White oak, weathered finish, filled and polished.

Has brass hoops, brass handles, which makes them neat, tasty and attractive.

In fact it is unique for this pattern has never been offered for sale before.

No. 71. Height over all $31 \frac{1}{2}$ in.

Depth of tub outside $9 \frac{1}{2}$ in. Depth of tub inside $8 \frac{1}{2}$ in. Top diameter outside $10 \frac{3}{1}$ in. Top diameter inside $9 \frac{1}{2}$ in. Weight $10 \frac{1}{2}$ lbs. Price $\$ 6.00$. 


\section{Seed Sowers and Sundries.}

\section{THE CAHOON SEED SOWER}

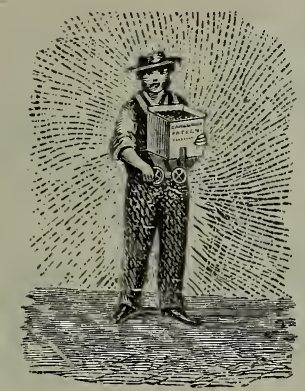

The difficulty in sowing is entirely overcome by the use of the Cahoon Broadcast Seed Sower which can be handled with ease by an entirely inexperienced person and will sow much more evenly than can be sown by hand. Price, $\$ 3.00$.

THE TIN HORN SEEDER

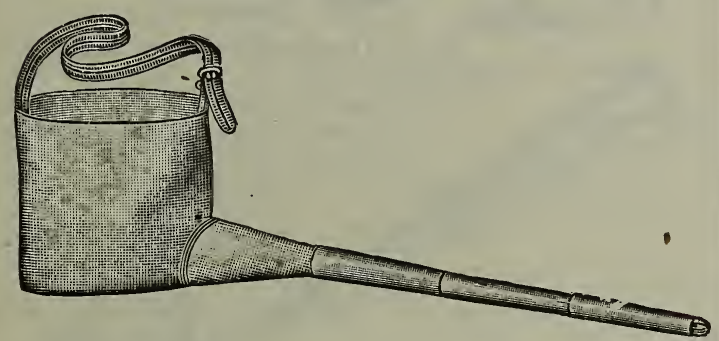

A light, accurate seeder that will broadcast clean seed from 30 to $40 \mathrm{ft}$. Length extended, 30 inches. Weight 12 ounces. Good heavy grade of ducking used on a sack.

\section{Price 90 cts.}

\section{THE CYCLONE SEEDER}

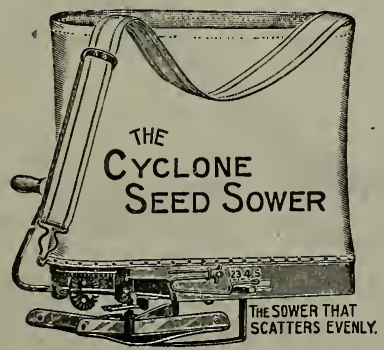

The Cyclone is a geared machine and works with a crank which seems to be the favorite; is strongly built of the best material. It has a 4-inch clear throat and cannot be choked, even with strawy oats. It will with proper care iast a lifetime. Price, $\$ 1.40$.

\section{FIDDLE BOW SEED SOWER}

Has been greatly improved, will sow all kind of grain and seed to your perfect satisfaction. Price $\$ 1.00$.

\section{THE RITTENHOUSE SEEDER}

Formerly sold under the name of "The Little Giant"

This Seeder has been on the market many years. Has a pressed tin four flange, distributing wheel and lathe centered gearings, making it casy running.

Accurate gauge.

Sloping feed board and force-feed steel frame. Hand hold and shield.

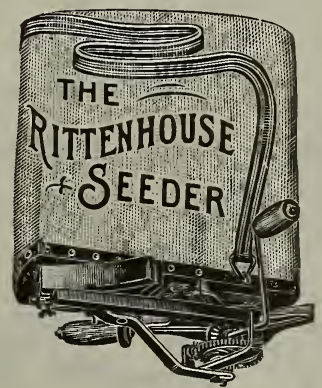

The most widely used type. Sack holds one-half bushel. Steel frame, convenient hand hold and body shield. Note how well it is braced. Price, $\$ 1.50$.

\section{THE RITTENHOUSE MOLE TRAP}

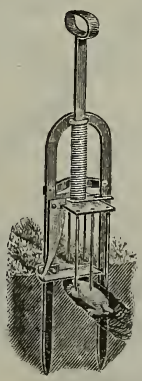

The simplest, safest and surest mole trap ever invented. Self-setting. No danger of its going off unless the trigger is touched. Made of all steel and tinned. The spears are spring steel, therefore do not have to be as long as soft steel. Price, 50 cents. 
Isn't it better to let your tools do the drudging rather than you? Isn't it commonsense for a farmer or gardener to work with tools that do the work of 3 to 6 men-do it better and get bigger crops?

\section{PLANET JR}

Two million farmers using Planter Jrs the world over testify that they save drudging. A practical farmer and manufacturer with over 35 years' experience makes them.

FREE-72 page farm and garden book for 1914.

You need this book. It's full of valuable farm and garden facts to help you get better crops with less work. 55 latest-improved tools shown, with one and two-horse cultivators, wheel hoes, seeders, harrows, etc. Send postal for it today!

No 3 Planet Jr. Hill and Drill Seeder-The No. 3 driving wheel is steel, with heavy forged steel spokes, not "piano wire," of proper height, with broad face, making the tool

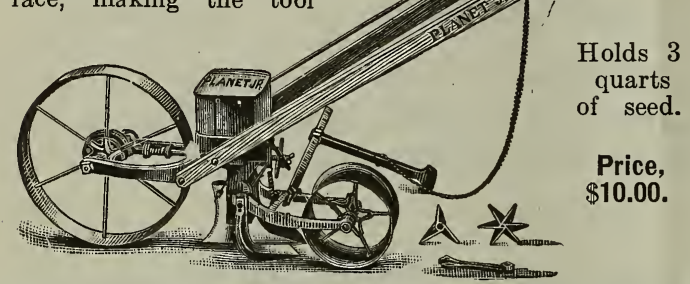

light and easy running, even with the hopper filled to the brim. A favorite among onion growers, market gardeners and seedsman.

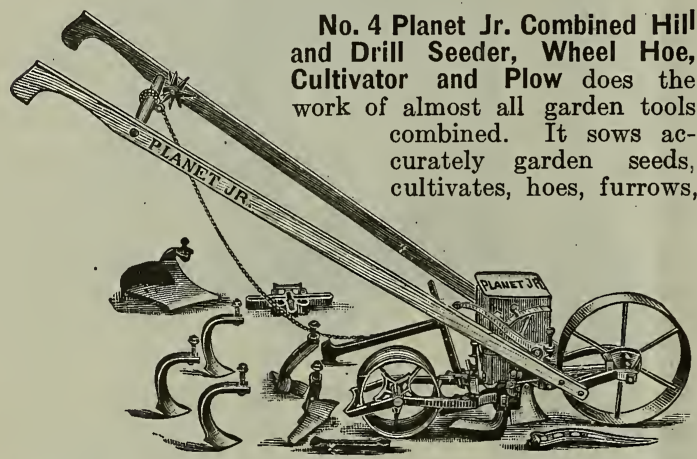

and plows. Fully guaranteed. Holds $2 \frac{1}{2}$ quarts. Price, Complete, $\$ 10.50$. Price, as a Seeder only, $\$ 8.50$.

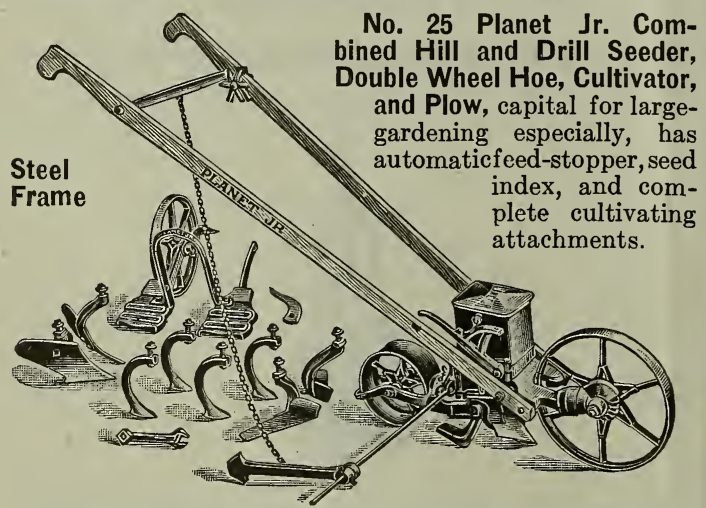

Indestructible steel frame. Holds $2 \frac{1}{2}$ quarts of seed. Price, $\$ 13.00$.

No. 8 Planet Jr. Horse Hoe and Cultivator does more kinds of work better, quicker, and easier than any other cultivator. Indispensable on the up-to-date farm. Price with all steel wheel, $\$ 8.75$.
No. 11 Planet Jr. Double Wheel Hoe, Cultivator, Plow and Rake works both sides of plants thoroughly and rapidly at one passage, until crops are 20 inches high. This fine tool has indestructible steel frame and steel leaf lifters. Price, $\$ \mathbf{8 . 5 0}$.

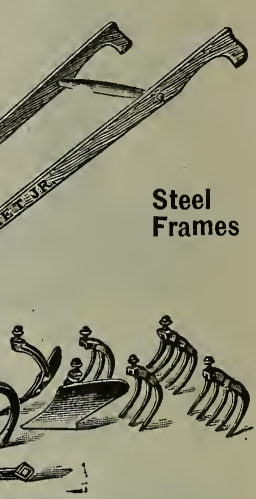

No. 12 Double Wheel Hoe, Cultivator

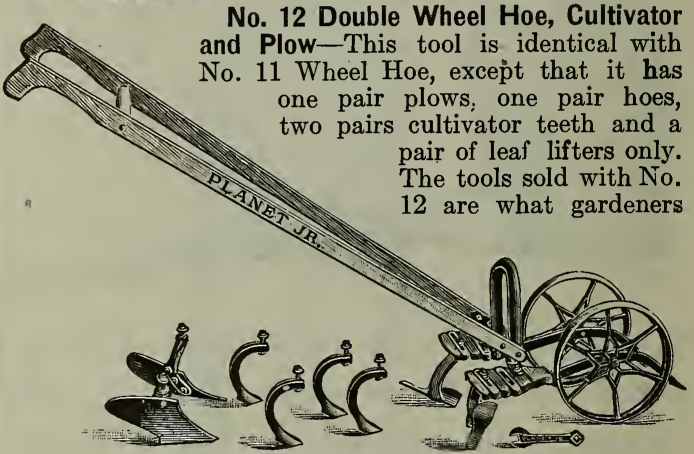

use most, and the others can be added as wanted. Weight, 34 lbs. Price, $\$ 6.50$.

No. 13 Double Wheel Hoe-This tool is the No. 11, with 6-inch hoes only, these being the tools that are most generally used. Price, $\$ 4.35$.

No. 16 Planet Jr. Single Wheel Hoe, Cultiv at or, Rake, and Plow is light, handy, and adapted to almost every garden use.

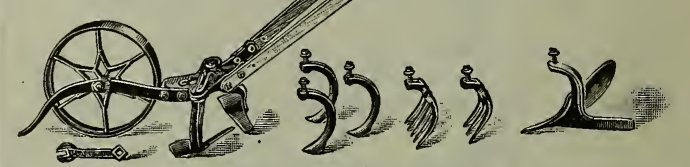

Has leaf guard for close work and lasting steel frame. Price, $\$ 5.35$.

No. 17 Planet Jr. Single Wheel Hoe-You can do more and better hoeing with it in one day than you can do in three days with a hand hoe. The No. 17 has a pair of 6 -inch hoes, a plow and a set of cultivator teeth, an outfit sufficient for most garden work. Price, $\$ 4.50$.

Planet Jr. Twelve-tooth Harrow, Cultivator and Pulverizer is invaluable in strawberry and truck patches and the market garden. Its 12 chisel-shaped teeth and pulverizer leave the ground in finest condition without throwing dirt on plants. Complete, $\$ 8.50$. Without pulverizer, $\$ 6.90$.

The successful farmer and gardener works with the Best Equipment. The day of old-fashioned tools is past. On the best-tilled farms and gardens the world over, Planet Jr tools are doing the work. 


\section{STOCK AND POULTRY SUPPLIES.}

\section{CONKEY'S POULTRY REMEDIES}

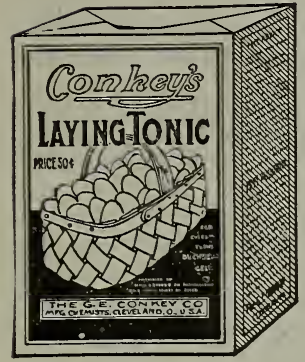

Conkey's Laying Tonic is a result of years of careful study and experiment, and is a compound of vegetable extracts, herbs, roots, etc., so proportioned as to act gently on the egg-producing organs to remove any irregularity which may exist, and to invigorate and tone the system to a point only that is perfectly natural in the highest state of the vigor and health of the fowl.

Conkey's Laying Tonic, $1 \frac{1}{2} \mathrm{lb}$. pkg., 250 : $3 \frac{1}{4} \mathrm{lb}$. pkg., 50 \&. Conkey's Cholera Remedy, 25غ and $50 \AA$ per pkg.

Conkey's White Diarrhoea Remedy, 50\& per pkg.

Conkey's Roup Remedy, 25\&, $50 \notin$ and $\$ 1.00$ per pkg.

Conkey's Poultry Tonic, $25 \&$ per pkg.

Conkey's Poultry Laxative, 25\& per pkg.

Conkey's Lice Powder, 5 oz. pkg., 10ф; 15 oz. pkg., $25 \dot{\text {. }}$

Conkey's Lice Liquid, 1 qt., 35ф; 2 qts., 60๕.

Conkey's Gape Remedy, 50\& per pkg.

Conkey's Head Lice Ointment, 1 oz. tube, 10\&; 3 oz. tube, $25 c$.

Conkey's Limber Neck Remedy, 50 ć per pkg.

Conkey's Nox-I-Cide, small size, 35k; 1 qt., 60 \&.

Conkey's Poultry Worm Remedy, $50 \notin$ per pkg.

Conkey's Chicken Pox (Sorehead) Remedy, $50 \notin$ per pkg.

Conkey's Rheumatic Remedy, 50\& per pkg.

Conkey's Bronchitis Remedy, 50\& per pkg.

Conkey's Scaly Leg Remedy, 25\& per pkg.

Conkey's Sulphur Fumigating Candles, $10 \notin$ each; 3 for $25 \notin$.

Conkey's Distemper Remedy, 50ধ.

Conkey's Mange Remedy, 50 .

Conkey's Hoof Remedy, 1 pint, 50\&; 1 quart 75\&.

\section{RUST'S POULTRY REMEDIES}

Rust's Egg Producer-One lb. box, $25 \%$.

Rust's Havens Climax Powder, Cure for Gapes, FowlCholera, Animal Diseases, etc. 13-oz. box, 25 .

Rust's Havens Roup Pills. For Fowls and Pigeons. Box of 50 Pills, 25 .

Rust's Liquid Lice-Killer, for applying in poultry houses and on perches and in nests. Directions on can. Quart can, 35k.

Rust's Lice-Killing Powder, for dusting fowls and nests. 5 oz. box, $10 \notin ; 16$ oz. box, 25 .

Rust's Roup Powder. An effective and sure cure for roup or colds. $25 \notin$ per pkg.

\section{LEE'S REMEDIES}

Lee's Lice Killer-1 gallon can, $\$ 1.00$; $\frac{1}{4}$ gallon can, 60 ; $\frac{1}{4}$ gallon can, 35 \&.

Germozone-In large twelve-ounce bottles at 50\& each or in boxes of 60 tablets (same value, for mailing) at same price.

Lee's White Diarrhoea Remedy-Prepared in $12 \mathrm{oz}$. bottles at 50 \& each.

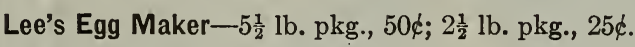

Lee's Insect Destroyer-A powder put up on $1 \frac{1}{4}$ pound sprinkler-top cans, very convenient for use. Price, 25k. Postpaid for 40 k.

Lee's Head Lice Ointment-Per box, 15 ф.

\section{INTERNATIONAL POULTRY FOOD.}

Absolutely pure and highly concentrated. One small feed of this has more medical effect than a very large one of many others. 100 feeds for 12 fowls for 25 k.

\section{INTERNATIONAL STOCK FOOD.}

Cures and prevents disease in horses, cattle, hogs, sheep, etc. Insures health and rapid growth for all young stock. A peculiar combination of medicinal ingredients makes this a superior and safe food for stock. $25 \&$ and $50 \notin$ box. "International Worm Powder"..............\$0.50

“International Heave Cure" .................. . .50

“International Gall Cure"..................... . .25

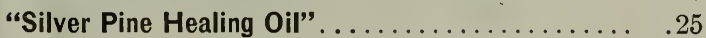

"International Colic Cure" ............... . .50

\section{SPRATT'S FOOD FOR DOGS.}

Spratt's Patent Dog Cakes, per pkg. . . . . . . \$ \$0.10 Spratt's Patent Puppy Cakes, per pkg......... . 10

\section{ELECTRIC LICE KILLING COMPOUND.}

For killing all Insects of Poultry; Mites and all Vermin that infest the Hen House. A' disinfectant against all Microbe Diseases, Roup, Swell Head, Gapes, Limber Neck and Cholera. 25\& per pkg.

\section{"BELL" GRAIN AND SEED AND SCREENINGS FOR POULTRY.}

Best on the market for the price.

10 lbs., 25k; 50 lbs., $\$ 1.00 ; 100$ lbs., $\$ 1.65$.

We handle a complete line of poultry supplies of the best quality. Prices are subject to important market changes. We will be glad to name special figures on large lots.

Come and see our establishment and be convinced that we are Headquarters for Poultry Supplies. 


\section{POULTRY SUPPLIES.}

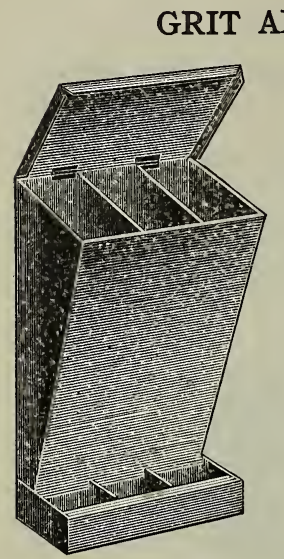

This box is made of heavy galvanized iron, with three compartments for grit, oyster shell, charcoal, etc. It is provided with a cover or lid which protects the contents. The box may be suspended on the wall of the poultry building by the handle. Box has a rounded bottom that throws every grain out into the apron. Weight 3 pounds.

Price, 50\%.

\section{MEAT SCRAP AND BRAN HOPPER}

\section{Has capacity of about 10 quarts and is adapted f or f e eding grain, beef scraps, bran, etc. Weight 2 pounds. Made of galvanized iron; round bot- tom.}

Price, 50c.

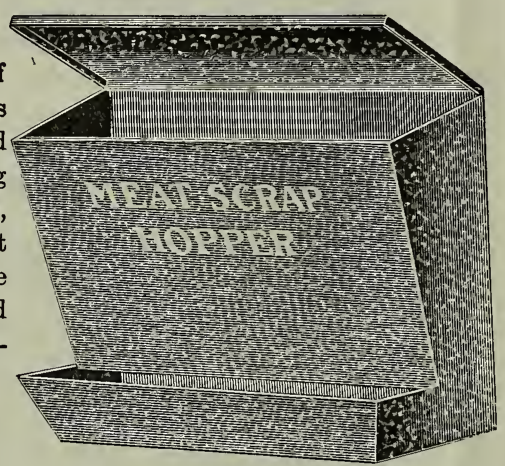

No. 4

\section{CELLULOID LEG BANDS}

\section{DURABLE AND PRACTICAL}

They mark your poultry so that you instantly know without handling, individual birds, one mating from another, and pullets from hens.

\section{Bands for Full-Grown Poultry}

Made in seven colors-Red, White, Blue, Pink, Amber, Black and Ruby. Prices: 12 for $25 \phi ; 25$ for $50 \phi ; 50$ for $85 \phi ; 100$ for $\$ 1.50$.

\section{Bands for Half-Grown Chicks}

Made in five colors-Red, Blue, Pink, Amber and Black. Prices: 12 for $25 \phi ; 25$ for $40 \phi ; 50$ for $75 \phi ; 100$ for $\$ 1.25$.

\section{LEADER ADJUSTABLE LEG BANDS}

Neatest, smoothest and most secure fastening of any adjustable band on the market. No. 1 size for Bantams and Leghorns. No. 2 size for all larger breeds and Turkeys. $15 \notin$ per doz.; 25 for $30 \notin ; 50$ for $50 \notin ; 100$ for $75 \phi$.

\section{ECLIPSE LEG BANDS}

Easily attached or removed; no tools required. $15 \notin$ doz.; 25 for $25 \phi ; 50$ for $40 \phi ; 100$ for $65 \phi$.

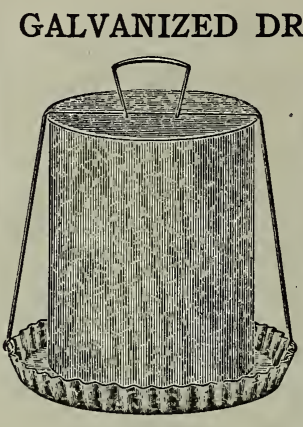

\section{DRINKING FOUNTAINS}

Clean pure water is the life of the chicks. Dirty water is sure death. Which are your chickens getting? Which would you rather have them drink?

Our many different styles of drinking fountains are designed to meet the poultryman's need. Chickens cannot drown. Will not run over. Made of galvanized iron and will not freeze and break as do the stone fountains. $25 \phi$.

N. W. AUTOMATIC FEEDER AND FOUNTAIN

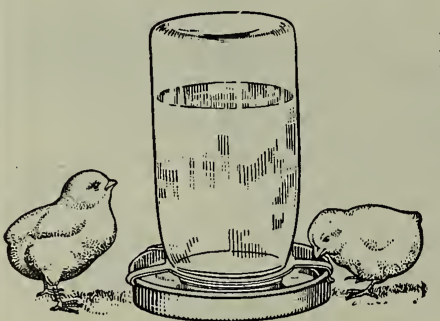

Made to fit any half gallon, quart or pint Mason jar. We do not furnish jars.

Two Sizes:

No. 5, having 5 inch pan, $10 \notin$ each; 3 for $25 \phi$.

No. 6, having 6 Patent Applied For.

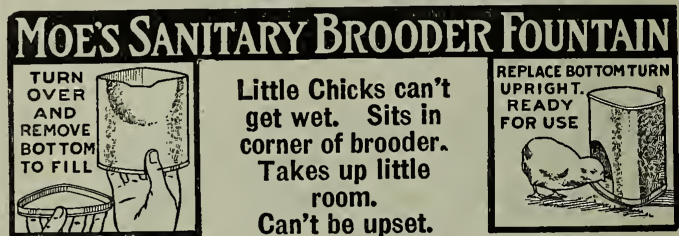

If desired can behung up by hook which is on top of each fountain.

No. 0 , one quart capacity..............\$0.25

\section{SANITARY STONEWARE FOUNTAIN}

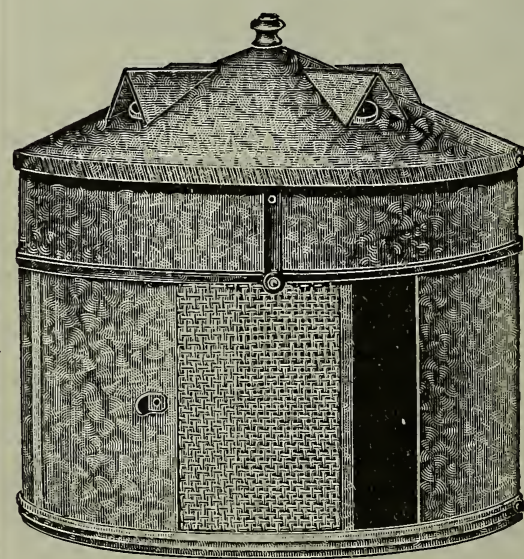

Burlington Brood Coop
The top is removable, allowing the fount to be thoroughly cleaned inside The proper thing to use where medicine is given in the drinking water. 1 qt., 20 \& each $\$ 2.00 \mathrm{doz}$. 2-qt. 25 c each $\$ 2.50 \mathrm{doz}$.

$\mathrm{R}$ o u n d metal coop made of galvanized iron, with sliding do or which can be fastened open at desired size. Adjustable top for ventilation. Rat, mink, weazel, mite and rain proof. Size 20 in. diameter, 20 in. high. Each $\$ 1.50$; doz., $\$ 16.00$. 


\section{POULTRY SUPPLIES.}

\section{SIX HOLE EGG TESTER}

Enables you to determine the live eggs after six days' setting. Not necessary to wait three weeks in order to tell which eggs will hatch. Throw the bad ones out and fill your incubator with good ones. No lamp or dark room necessary. Any one can test eggs with this egg tester. Made of good quality tin. Weight, about $\frac{1}{2}$ pound. Price, $75 \notin$ each.

\section{ONE HOLE EGG TESTER}

This Egg Tester tests one egg at a time. Some people prefer to test only one egg at a time, and we are in a position to furnish both styles.

Will fit any incubator lamp. Weight $5 \mathrm{oz}$. Price, $10 \xi$.

\section{WALL FEED TROUGH}

\section{No. 3.}

Keeps feed clean and also keeps hen house clean. Is used for either dry or wet mesh. Can be hung on the wall. Much feed is lost when thrown on the floor. This trough prevents soiling or trampling feed under foot and enables each bird to get its share. Size $31 \frac{1}{2}$ in. long, $5 \frac{1}{2}$ in. wide, $5 \frac{1}{2}$ in. high. Weight $2 \frac{3}{4}$ pounds. Price, $45 \&$ each.

\section{RUBBER ROOFING}

Reverso-In rolls 32 in. wide, containing 108 sq. $\mathrm{ft}$. Eith er side the right side. 1 ply, $\$ 1.25 ; 2$ ply, $\$ 1.50 ; 3$ ply, $\$ 1.75$.

Ampco High Grade-Rolls 32 in. wide. 108 sq. ft. 1 ply, $\$ 1.50 ; 2$ ply, $\$ 1.75 ; 3$ ply, $\$ 2.00$.

The best and most durable roofing that can possibly be made

\section{FEEDS FOR POULTRY}

\section{Prices Subject to Market Changes.}

Alfalfa Meal, choice......3 lbs. $\$ 0.15$

High Protein Meat Scraps..6 lbs. .25

Beef Meal. ............. 6 lbs. .25

Kaffir Corn, white recleaned 4 lbs: .15

Sunflower Seed, recleaned. . 3 lbs. . 25

Cracked Corn............ 5 lbs. .15

Bran............... 5 lbs. .15

Whole Corn, shelled....... 6 lbs: .15

Buckwheat, recleaned...... 4 Ibs. .15

Chicken Wheat.......... 5 lbs. .15

Feed Barley........... 4 lbs. .15

Chicken Millet........... 5 lbs. . 15

Oats................. 5 lbs. .15

Linseed or Oil Meal....... 4 lbs. .15

Cotton Seed Meal......... 5 lbs. .15

Granulated Bone.........6 6 lbs. .25

Charcoal.............. 3 lbs. .10

Oyster Shells............. 10 lbs. . 10

Mica Crystal Grit......... 10 lbs. .10

Poultry Mash........... 5 lbs. .15
$6 \mathrm{lbs} . \$ .25$

$13 \mathrm{lbs}$. .50

$13 \mathrm{lbs} . \quad .50$

$8 \mathrm{lbs} . .25$

10 lbs. .50

$10 \mathrm{lbs} . .25$

10 lbs. .25

$12 \mathrm{lbs} . .25$

$8 \mathrm{lbs} . .25$

10 lbs. .25

8 lbs. .25

$10 \mathrm{lbs}$. .25

$10 \mathrm{lbs}$. .25

8 lbs. .25

10 lbs. .25

13 lbs. .50

$8 \mathrm{lbs} . .25$

50 lbs. .45

50 lbs. .45

$10 \mathrm{lbs}$. .25

\section{dilít}

\section{POULTRY FEED}

A perfectly balanced ration, keeps the fowls in fine condition. With this feed the pullets quickly develop and begin laying generously. 4 lbs., 15\&; 8 lbs., 25\&; 100 lbs., $\$ 2.10$.

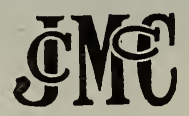

\section{CHICK FEED}

This food has been prepared with the idea of supplying a perfectly balanced ration for young chicks. It has been demonstrated that young chicks do much better on our especially prepared feed than on any moist or soft food that can be obtained. The food is composed of various kinds of grains, bone and other nutritive foods, making it the most complete and cleanest chick food on the market. Price, 4 lbs., $15 \notin ; 8$ lbs., 25\&; 100 lbs., $\$ 2.25$.

\section{ALFALFA MEAL}

Is pure Alfalfa, ground to meal, buds, stalk and all. It is nature's most perfect gift to the breeder of poultry or live stock. Used in the mash. Per lb., 5\&; 6 lbs., 25\%; 50 lbs., \$1.00; 100 lbs., $\$ 1.90$.

Send us an estimate of your wants in larger quantities for special prices.

\section{LIME NEST EGG}

This egg contains $75 \%$ Calcium Carbonate, a disinfectant-that absorbs foul gases and is repulsive to lice and vermin. This egg is coated with a heat retaining solution and chills very slowly in damp and cold weather. Each egg is an exact duplicate of a real chicken egg. 5e each; $50 \notin$ dozen.

\section{LICE EXPELLING NEST EGG}

The Lice Expelling Nest Egg is the standard combined nest egg and lice killer. The use of this nest egg insures absolute freedom from all kinds of insect pests in the nests. Being prepared with great care for this special purpose, they last a long time and always retain their effectiveness. Prices: $5 \notin$ each; $50 \notin$ per dozen.

\section{PORCELAIN NEST EGGS}

These eggs are made of first-class flint glass, and should last a life-time. Prices; 2 for 5ф; $25 \xi$ per dozen.

Call and see our new Store at 230 and 232 East Fourth Street, North Side, between Main and Sycamore Streets, and be convinced that we are the largest and best equipped Seed and Poultry Supply House to be found anywhere. 


\title{
BUCKEYE INCUBATORS.
}

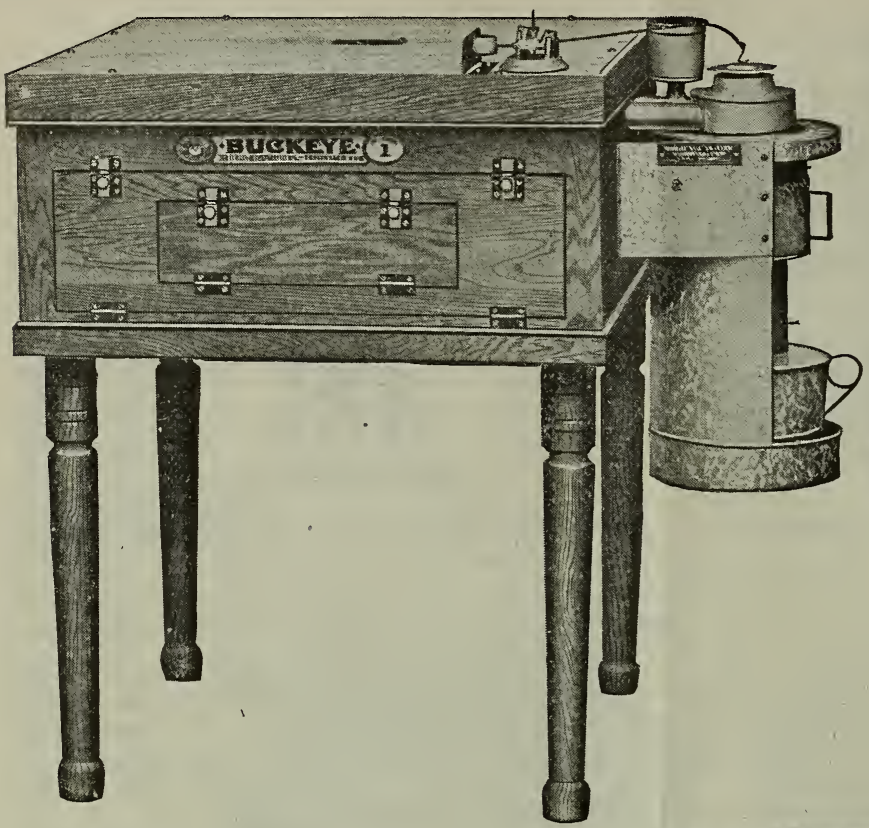

\author{
The Standard of Perfection in \\ Artificial Incubation
}

\section{ANYBODY CAN HATCH CHICKENS WITH A "BUCKEYE"}

There are over 325,000 Buckeye Incubators in successful operation

\section{PRICE LIST}

Style A, Capacity 60 Eggs......... $\$ 10.00$ No. 1, Capacity 110 Eggs......... 18.00 No. 2, Capacity 175 Eggs......... 23.00 No. 3, Capacity 250 Eggs......... 30.00 No. 4, Capacity 350 Eggs......... 35.00

Let us show you a Buckeye in operation and prove to you that they will hatch more Chicks and better Chicks than any old hen or incubator you ever owned.

\section{A CHICK FROM EVERY HATCHABLE EGG}

\section{BUCKEYE BROODERS INDOOR HEATED TYPE}

No. 1, Capacity 50 Chicks........\$8.00

No. 3, Capacity 100 Chicks........ 10.00

\section{OUTDOOR HEATED TYPE}

No. 2, Capacity 50 Chicks........\$12.00

No. 4, Capacity 100 Chicks........ 18.00

\section{BUCKEYE COLONY HOUSES PORTABLE}

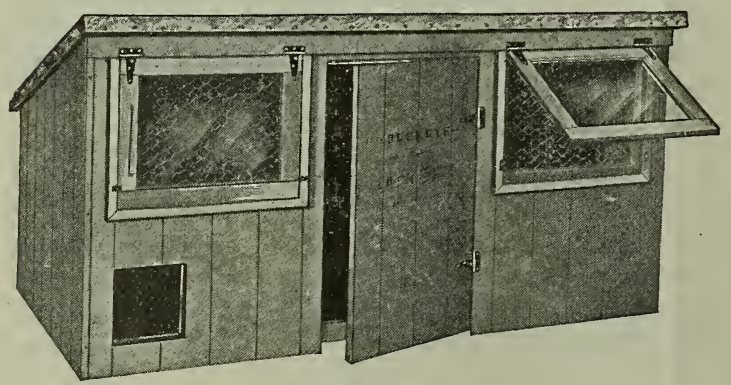

Wood Front Colony House

6 feet long; 8 feet deep. Front, $6 \frac{1}{2}$ feet high. Back $4 \frac{1}{2}$ feet high.

Complete with floor and roosts..............\$14.00

Wire Front Colony House

Complete with floor and roosts...............\$13.00

TEither house can be "set up or taken down" in ten minutes and the only tool necessary is a screw driver.

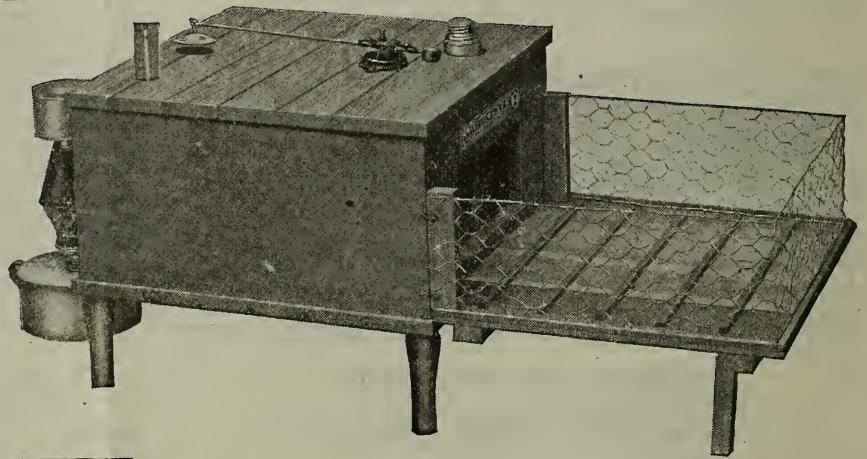

If you already have incubators, we want you to try a Buckeye and see how much better it is than any incubator you have ever used.

Learn how many more eggs you can batch with a Buckeye.

Note the difference in the size and strength of the Chicks when they are hatched!

We consider this point one of the most important features of the Buckeye, as the profitable chicks are those that have plenty of size, vitality and vigor when they are hatched.

A Buckeye incubator will not only hatch every hatchable egg, but it will produce a uniformly larger and stronger chick than can be hatched by any other method, including the old hen herself.

The value of this feature cannot be overestimated as the chick started right, will stay right and grow much more rapidly than his smaller and weaker brothers.

If you have never used an incubator, try a Buckeye first, and you'll save money, time and trouble.

You keep the lamp burning and turn the eggs twice a day.

With a Buckeye you have no ventilation or moisture worries.

It's purely automatic and you can't make a mistake. 


\section{POULTRY SUPPLIES.}

\section{THE "6 IN - 1" EXERCISER FEEDER}

It has all the good features of other exercisers and feeders, plus 5 additional compartments.

Specifically, it is a large hopper supported on 4 strong iron legs and designed to keep constantly before chickens all the food necessary for them. The user of a " 6 in 1 " can place it in his hen house, fill it and then go away for several

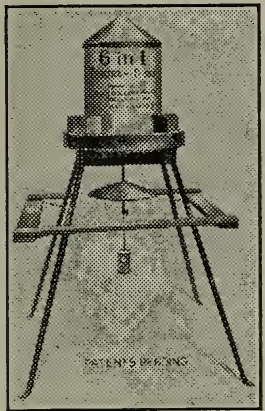
days without misgivings about the feeding of his flock. The " 6 in 1" will attend to that.

The ordinary exerciser and feeder has one compartment containing mixed grains. The "6 in 1" has this central compartment, and in addition has 5 others-for dry mash, meat, oyster shell, grit, and charcoal.

Connected with th€ central hopper (that for mixed grains), is an agitator," loaded with whole corn as bait. When the fowls pick at the bait, a small quantity of the mixed grain falls on the deflector, and is scattered widely in the litter on the floor. Scratching vigorously for the grains, the hens get just the exercise they need.

The body of the " 6 in 1 " can be lifted from the legs and placed on the floor, in which position it makes a perfect chick feeder.

The "6 in 1" comes pretty near to being a downright necessity to the poultryman. With it in his hen house he can be sure that his fowls will exercise, which means vigor, and eat a balanced ration, which means eggs.

The top of the " 6 in 1 " is conical in shape. The fowls positively cannot roost upon it. Price:

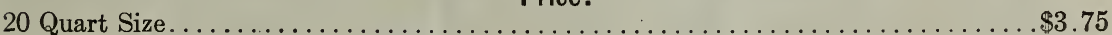

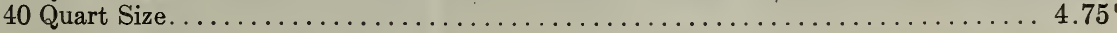

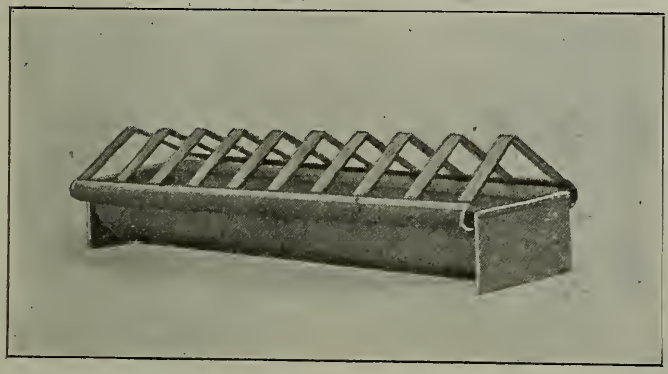

CHICK TROUGH

Chicks can not get into it to dirty the food. The top removes to fill or clean. Is very little trouble. No expense and no danger. Price, Small, 30ф; Large, 50£.

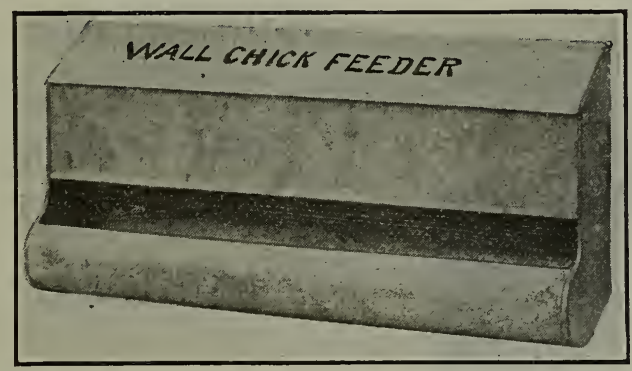

The best device made for feeding Dry Mash, Little Chick Grains, Grits, Charcoal, etc., to Baby Chicks. Price, 10 in., 50 \&; 20 in., 75 \&.

\section{EGGS FOR HATCHING}

We are prepared to furnish Single Comb Rhode Island Red Standard Bred, High record Stock. Prices per setting of 15 :

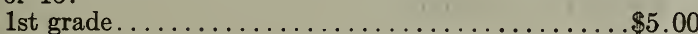

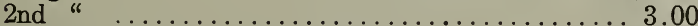

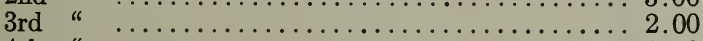

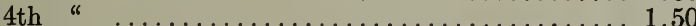

R. I. Red Cocks and Cockerels, $\$ 3.00, \$ 5.00, \$ 10.00$ each.

R. I. Pullets, $\$ 2.50, \$ 3.00, \$ 5.00$ each.

R. I. Baby Chicks, $\$ 1.75$ dozen.

White and Brown Leghorn Eggs, $\$ 1.00$ per setting of 15.

White and Brown Leghorn Baby Chicks, $\$ 1.50$ dozen.

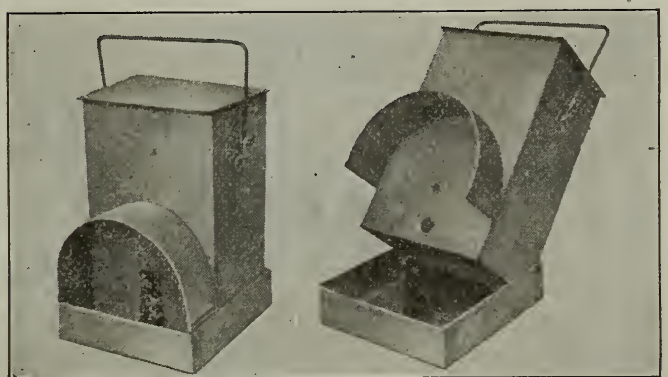

SQUARE BOTTOM DRINKING FOUNTAIN

Made of heavy Galvanized Iron. Easy to clean. Pre-

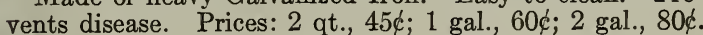

\section{TWO PIECE GALVANIZED DRINKING FOUNTAIN}

The chicks can not get into the basin to foul the water nor to drown, and will not roost on the top. They are easily cleaned, are light and durable, and will not freeze and burst in winter. Prices: 1 qt., 20k; 2 qt., 25k; 1 gal. $40 \dot{c}$.
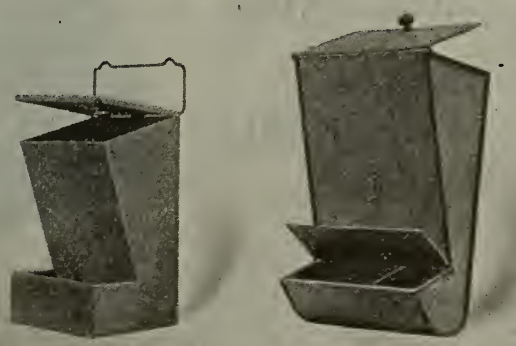

\section{GRIT AND SHELL BOX}

This box is made of heavy galvanized iron, with three compartments, for grit, oyster shell and charcoal or beef scrap. It is provided with a cover or lid, which protects the contents. The box may be suspended on the wall of the poultry building by the handle. Prices: Round bottom, 50\&; Rectangular bottom, 40 . 


\section{POULTRY SUPPLIES.}

To our Poultry Supply Customers:-

Owing to our new location at 230 and 232 East Fourth St., between Main and Sycamore Sts., we have enlarged our Poultry Supply Department. ' Many articles of merit have been added and our supplies are the best the market affords.

Our customers will not be disappointed in any articles ordered from this catalogue.

Our line of Poultry Feeds, etc., includes everything necessary to the sucessful rearing of Poultry. We aim to handle only "the best" and to give our customers "value received for every dollar expended." Back of these feeds is our own reputation and that of responsible concerns that assemble them.

While we are always glad to have customers call at our store and inspect goods, orders by mail will receive the same prompt and careful attention.

THE J. CHAS. McCULLOUGH SEED CO.

\section{B U C K E Y E \\ Kant-Krowd Fresh Air \\ H O V E R}

SIMPLE,

FIRE PROOF,

CONVENIENT,

LICE PROOF,

DURABLE.

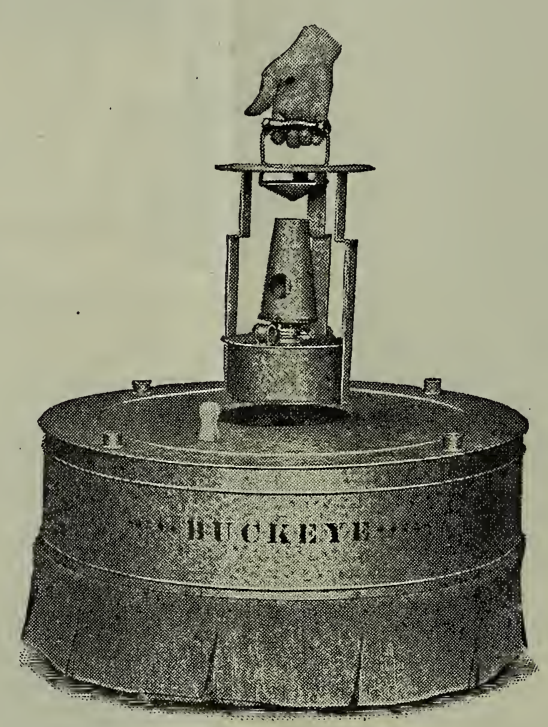

Exterior View
SAFE,

\section{ECONOMICAL,}

FOOL PROOF,

SANITARY,

PRACTICAL.

THE ONLY PERFECT METAL HOVER.

Warmest at the CURTAIN.

The CHICKS can't Crowd.

Perfect automatic ventilation. The CHICKS must thrive.

It is portable and easily heated anywhere-in doors, or out of doors, in a colony house of any character-even with the temperature below freezing. Assembled complete when shipped-Ready to light the lamp. PRICE $\$ 8.50$. 


\section{Quantity of Seed requisite to produce a given number of plants and sow an acre.}

Artichoke, $1 \mathrm{oz}$. to 500 plants.............. 6 oz. Asparagus, $1 \mathrm{oz}$. to 500 plants............... 1 lb. Asparagus Roots.............................. to 7250

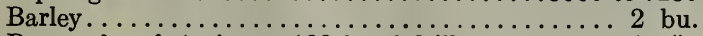
Beans, dwarf, 1 pint to $100 \mathrm{ft}$ of drill ..........

Beans, pole, 1 pint to 100 hills.

Beet, garden, $1 \mathrm{oz}$. to $100 \mathrm{ft}$. of drill............. $7 \mathrm{lbs}$.

Beet, Mangel, $1 \mathrm{oz}$. to $100 \mathrm{ft}$. of drill............. 5 "

Broccoli, 1 oz. to 3000 plants................ 3 oz.

Brussels Sprouts, 1 oz. to 3000 plants............ 3 "

Buckwheat........................ 1 bu.

Cabbage, 1 oz. to 3000 plants................ 3 oz.

Carrot, $\frac{1}{2}$ oz. to $100 \mathrm{ft}$. of drill.................

Cauliflower, $1 \mathrm{oz}$. to 3000 plants.............. 3 oz.

Celery, 1 oz. to 5000 plants. . . . . . . . . . . . . 4 "

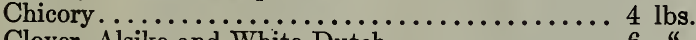

Clover, Alsike and White Dutch............... 6

Clover, Alfalfa or Lucerne.............20 to 30 "

Clover, Crimson.................... 10 to 15 "

Clover, Large Red and Medium............. 10 to 15

Corn, Pop (shelled) ....................

Corn, Sweet, $\frac{1}{4}$ pint to 100 hills.............. 8 "

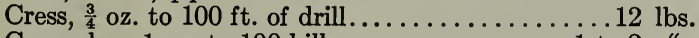

Cucumber, 1 oz. to 100 hills.................. to 2

Egg Plant, 1 oz. to 2000 plants............. 4 oz.

Endive, $1 \mathrm{oz}$. to $150 \mathrm{ft}$. of drill. ............

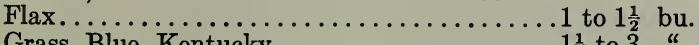

Grass, Blue, Kentucky ................ $1 \frac{1}{2}$ to 3

Grass, Blue, English......................

Grass, Hungarian and Millet..............

Grass, Mixed Lawn........................ to 6

Grass; Red Top, Fancy Clean........... 8 to $10 \mathrm{lbs}$.
Quantity per acre

Grass, Timothy ...................... Grass, Orchard, Perennial Rye, Red Top and Wood

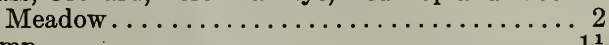

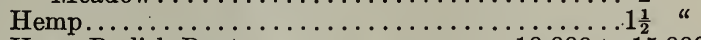

Horse Radish Roots................. 10,000 to 15,000

Kale, 1 oz. to 2000 plants................ $\frac{1}{2}$ lb.

Kohl Rabi, $\frac{1}{3}$ oz. to $100 \mathrm{ft}$ of drill ............. 4 lbs.

Leek, $\frac{1}{3}$ oz. to $100 \mathrm{ft}$. of drill $\ldots \ldots \ldots \ldots \ldots \ldots \ldots 4$

Lettuce, $\frac{\mathrm{r}}{4} \mathrm{oz}$. to $100 \mathrm{ft}$. of drill............... 3 "

Melon, Musk, $1 \mathrm{oz}$. to 60 hills.............. to 3 "

Melon, Water, 4 oz. to 100 hills..................

Nasturtium, $2 \mathrm{oz}$. to $100 \mathrm{ft}$. of drill................

Okra, 1 oz. to $100 \mathrm{ft}$. of drill....................

Onion Seed, $1 \mathrm{oz}$. to $100 \mathrm{ft}$. of drill.......... to 5 "

Onion Seed, for Sets................... to 80 "

Onion Sets, 1 quart to $40 \mathrm{ft}$. of drill.......... 8 bu.

Parsnips, $1 \mathrm{oz}$. to $200 \mathrm{ft}$. of drill............. $5 \mathrm{lbs}$.

Parsley, $1 \mathrm{oz}$. to $150 \mathrm{ft}$. of drill................... 3 "

Peas, garden, 1 pt. to $80 \mathrm{ft}$. of drill.......... to $3 \mathrm{bu}$.

Peas, field............................

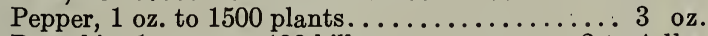

Pumpkin, $\frac{1}{3}$ quart to 100 hills...............

Radish, $1 \mathrm{oz}$. to $100 \mathrm{ft}$. of drill...............

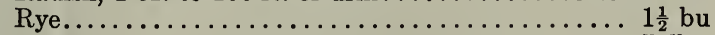

Salsify, $2 \mathrm{oz}$. to $100 \mathrm{ft}$. of drill.............. 7 lbs.

Spinach, $1 \mathrm{oz}$. to $100 \mathrm{ft}$. of drill.............

Summer Savory.........................

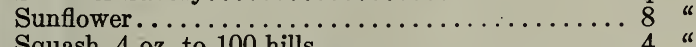

Squash, 4 oz. to 100 hills...................

Tomato, 1 oz. to 4500 plants..................

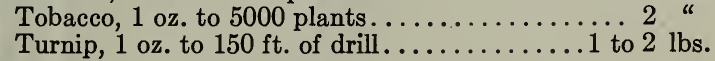

\section{Number of Plants or Trees to the Acre at Given Distances.}

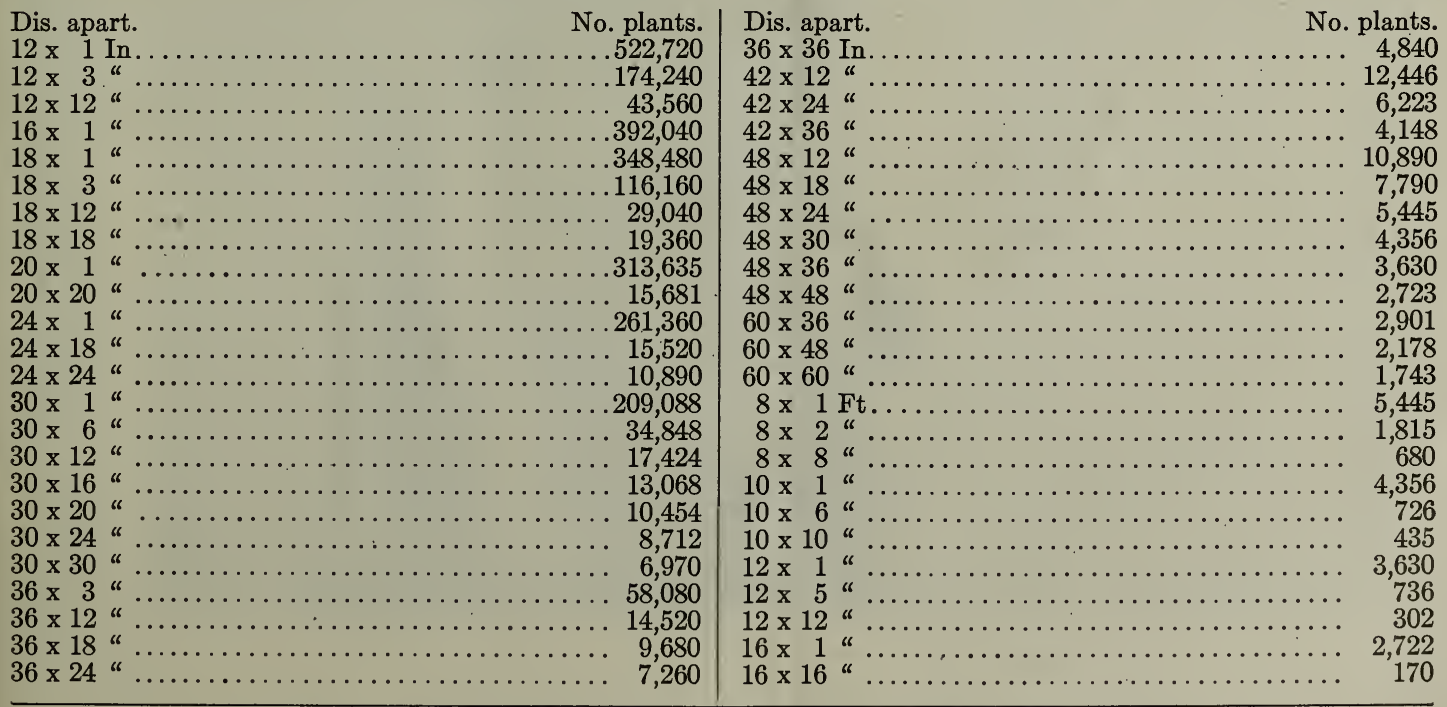




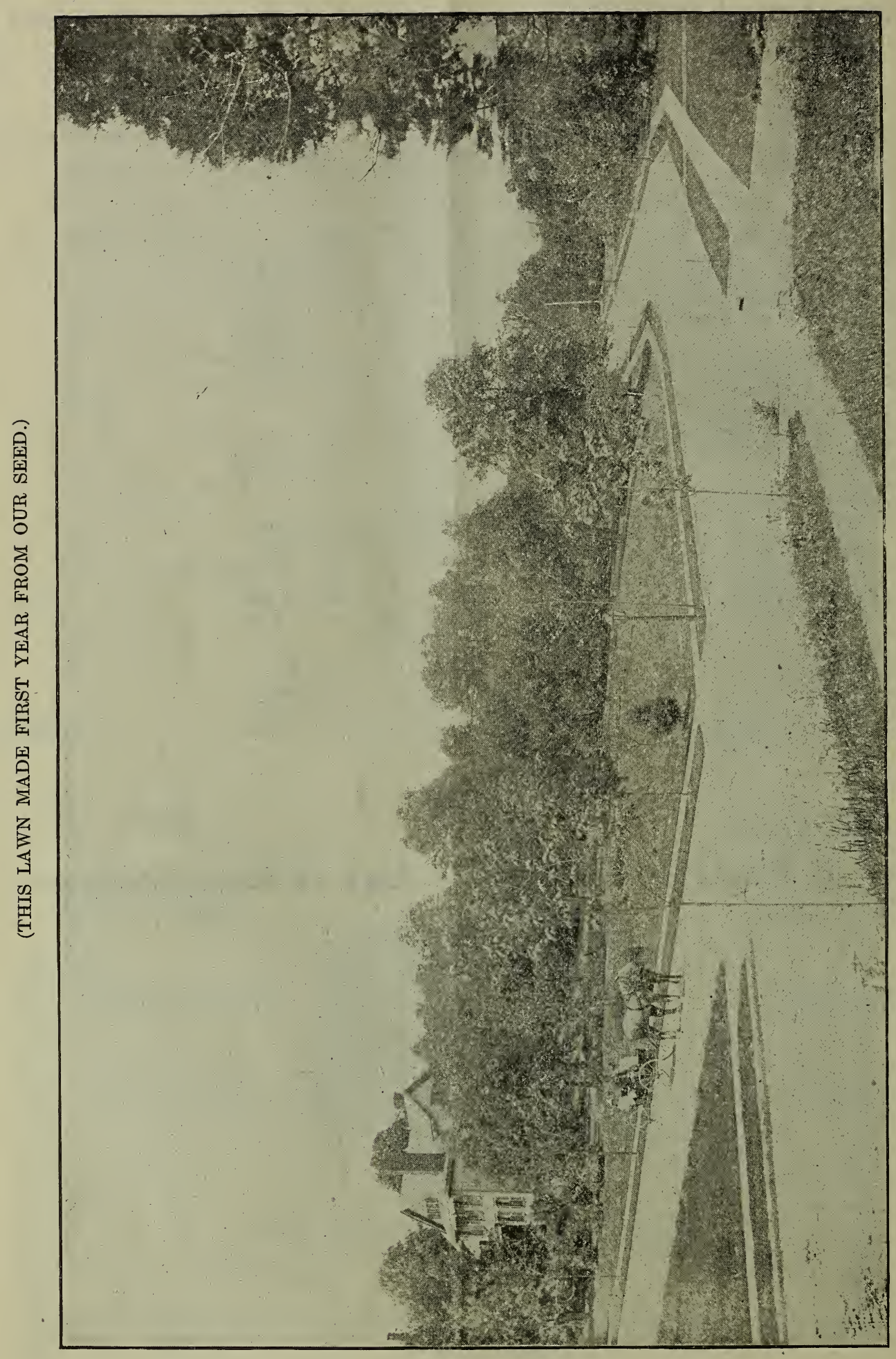

兽

है

ज्ञ

क्षै

矛密

兘它完

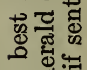

혁 모

ส충

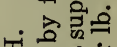

四 .

응 สํํ

붑웅으

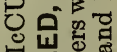

岕产。

यु की

荷通

宁造

노응

궁요

된

星爱骂

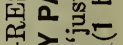

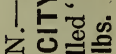

요요

50 .

药

政

응.

응해

곡

Oे

녹

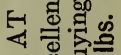

3 ํㅡㅇ

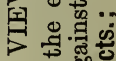

요ำ

त्ञ

궁-

के.

递芯

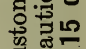

วิ

荫

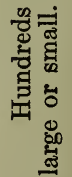




\begin{tabular}{|c|c|c|}
\hline Page & Page & Page \\
\hline Alfalfa........ & Grass Catcher.............51 & Rollers, Lawn.................51 \\
\hline Ashes, Canada, Hardwood.......25 & Grass Seeds...........19 to 22 & Rose Bushes........ \\
\hline Asparagus.... & Guns, Powder..... & Rutabaga.......... \\
\hline Atomizers.... & Herbs............ & Shade Trees..... \\
\hline Bag Holders. . & Horticultural Tools.... & Shrubs... \\
\hline Bird Houses. . & Hedge Plants......... & Salsify... \\
\hline Brooders. . & Incubators $\ldots \ldots \ldots \ldots \ldots$ & Scalecide.. \\
\hline Beans........... & Insectcides. . . . . . . . . . . 47 & Spinach. . \\
\hline Bedding Plants... & Kale........... & Speltz. \\
\hline Beet. & Knives, Budding and Pruning.....52 & Seed Sowers, Bro \\
\hline Bellows, Powder. & Kaffir Corn....... & Seed Ranch.... \\
\hline Blue Grass. . & Labels, Wood.... & Small Fruits.......... \\
\hline Bone Meal. & Lawn Grass Seed.........18, 19, 64 & Seeds, Flower..........26 to 33 \\
\hline Barley.... & Lawn Fertilizer......... & Seeds, Bird and Miscellaneous.....24 \\
\hline Broom Corn. & Lawn Mowers.................51 & Seeds, $\mathrm{Fa}$ \\
\hline . . 34 to 36 & Lawn Rollers...............51 & Seeds, Grass and Clover......19 to 22 \\
\hline Buckwheat & Lawn Supplies.............51 & Seeds, Veg \\
\hline Cabbage. & Lettuce ..............9, 10 & 9,64 \\
\hline Caladium Bulbs. & Millet.... & Sheep Manure. . \\
\hline Canna Bulbs.... & Mole Traps......... & Cho \\
\hline Carrot... & Moss................ & \\
\hline Cauliflower. & Melon, Musk.............11 & pecialties. \\
\hline Cane Seed. & Melon, Water............. 10, 11 & pades. \\
\hline Cele & Mills Clipper. . & yus \\
\hline
\end{tabular}

Chick Feed.............. 59

Clovers................21, 22

Corn, Field...............22

Corn, Pop............. 8

Corn, Sweet............ 8

Cow Peas..................23

Cucumber.............. 8,9

Dahlias.................

Evergreens............44, 44

Farm Seeds..............33, 24

Farmogerm................24

Fertilizers...............25

Flower Seeds............26 to 33

Flower Pots................5 53

Flower Tubs................53

Fruit Trees.............44, 45

Garden Seeds............. to 17

Garden Seed Drills............56

German Millet...............21

Gladioli.
Mushroom Spawn............12

Nursery Stock...........37 to 46

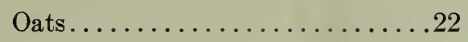

Onion Seed................ 12

Onion Sets.................. 12

Orchard Grass...............21

Peas, Garden.............13, 14

Peas, Cow and Field...........23

Peach Pits..................24

Planet Jr. Tools. . . . . . . . . . .56

Plants, Vegetable...........17, 18

Potatoes..................25

Poultry Supplies.........57 to 62

Pumpkin................. 14

Pumps, Spray..........48, 49

Radish...............14, 15

Rape, Dwarf Essex............24

Raffea................52

Rakes, all sorts............ 22

Red Top.................
Suggestions to customers, $2 \mathrm{~d}$ page of cover.

Sprayers............48, 49

Supplies, Stock and Poultry......57

Sunflower............23, 24

Sweet Clover................22

Table of Weights, etc.........663

Timothy..................21

Tobacco..................17

Tomato...............16, 17

Trowels, Garden............ 52

Tuberoses................... 36

Turnip.................... 17

Vegetable Plants and Roots....17, 18

Vegetable Seeds...........3 to 17

Vetches..................23

Vines....................42

Weeders, Hand ............. 2

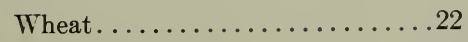

"When to Spray"............50 


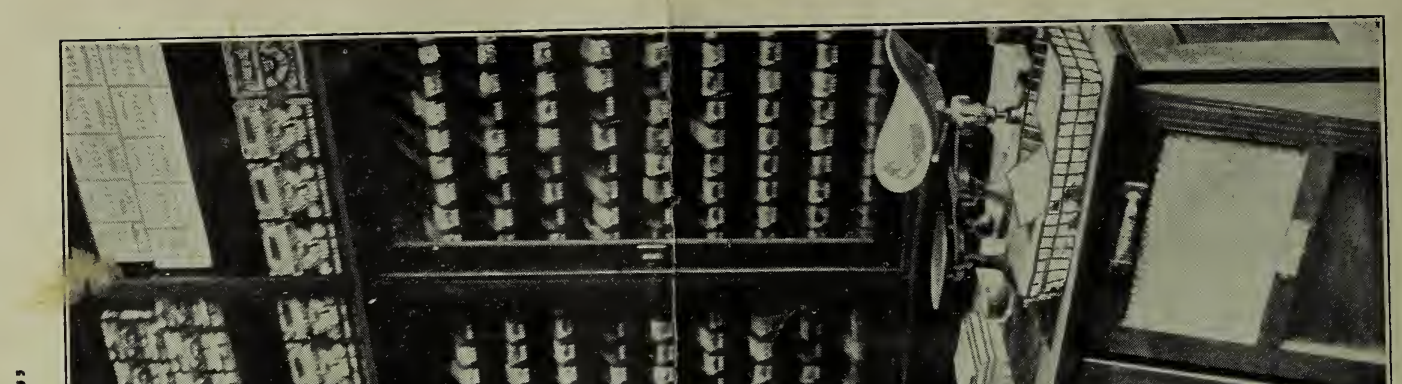

î

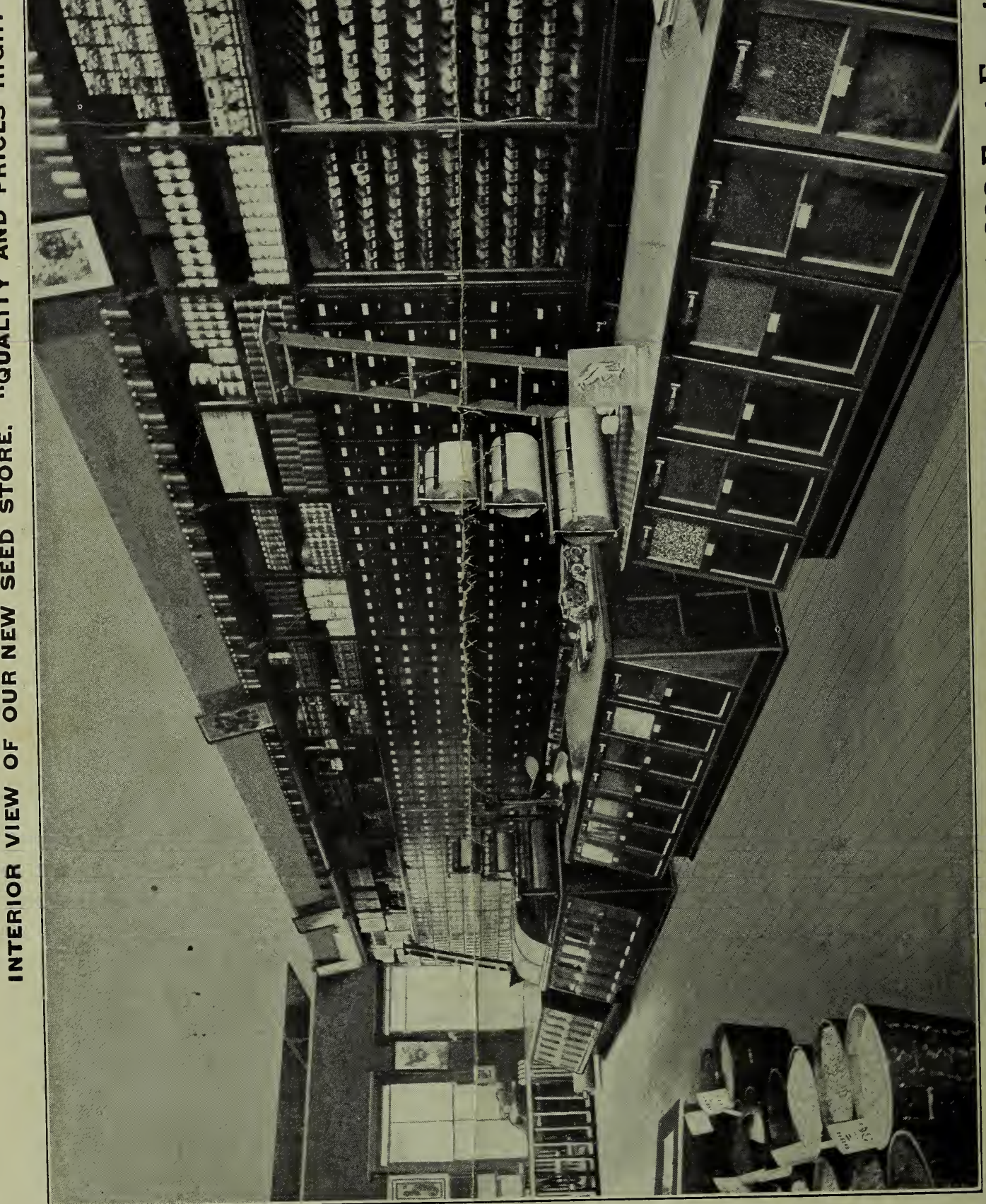

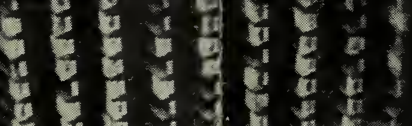

•

온둥

b3

II

+3

징

늘

กิ

0

ก

政

:

$0 \%$

Q는

[I]

ช2

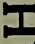

5

0

$-1$

$D$

0

$\sum$ 视是

ข่붕

4

눙

$\rightarrow$ 욤

[1]

$z \frac{u}{\alpha}$

w

a

0

5 u 